\title{
Estrutura Genética de Populações de JEQUITIBÁ-ROSA [Cariniana legalis (MART.) O. KTZE] POR CARACTERES QuaNTITATIVOS E ISOENZIMAS
}

AleXandre Magno Sebbenn

Engenheiro Florestal

Orientador: Prof. Dr. Paulo Yoshio Kageyama

Tese apresentada à Escola Superior de Agricultura "Luiz de Queiroz", da Universidade de São Paulo, para obtenção do título de Doutor em Agronomia, Área de Concentração Genética e Melhoramento de Plantas.

PIRACICABA

Estado de São Paulo - Brasil

Junho - 2001 


\section{Errata}

Página ix - Resumo: Primeira página - Linha $14=$ apresentaram

Página $\mathbf{x}$ - Resumo: Segunda página - Linha 23 = referido

Página 1 - Introdução: Terceiro parágrafo, penúltima linha = Também foi observado baixa divergência ....

Página 12 - Na Tabela 1, onde lề-se n, substituír por ...

Página 25 - Segundo parágrafo, última lỉnha = parâmetros

Página 31 - Segundo parágrafo, Linha $20=$ Geburek (1986)

Página 39 - Segundo parágrafo, Linha $1=\mathrm{O}$ conhecimento do coeficiente ....

Página 25 - Segundo parágrafo, última linha $=$

Todo texto $=$ sub-parcelas $=$ subparcelas

Página 63 - Segundo parágrafo, Linha 3 e 63 equação $40=$ Substituir $\hat{G}_{S T}$ por $\hat{F}_{S T}$.

Nas Tabela 15, 16, 17, 18 e 20, nas esperanças dos quadrados médios, os componente da variância não recebem "chapeuzinho", por tratar-se do próprio parâmetro.

Página 70 - Último índice. A diversidade gênica esperada $\left(\hat{H}_{\varepsilon}\right)$ não viesada

Página 76, 80, 82 - caractere $=$ caráter

Página 80 -Tabela 19

\begin{tabular}{rcr} 
& \multicolumn{2}{c}{ Campinas } \\
\cline { 2 - 3 } Classe & LA & PE \\
\hline 1 & 26 & \\
3 & & $>10 a<15$ \\
4 & & \\
5
\end{tabular}

Página 81 - Primeiro parágrafo, última linha: 75 e 76

Página 85 - Primeiro linha: 129

Segunda linha: Como não se conhece o parentesco

Página 88 - Equação 142: $\hat{\sigma}^{2}=\hat{\sigma}_{B}^{2}$ 
Página 92 - Tamanho efetivo: depois

Página 101 - Terceiro parágrafo, Linha 3: onde lê-se ..., embora as estimativas ..., ler ..., além das estimativas...

\section{Página 105}

O crescimento médio $(\bar{x})$ e o incremento médio anual (IMA) dos caracteres apresentaram melhor desempenho em Luiz Antonio (Tabela 25). As médias entre populações dos caracteres FF, DAP, ALT, VC e SOB em Luiz Antonio, foram 9,9\%, $5,7 \%, 24,1 \%, 37,9 \%$ e $3,4 \%$, respectivamente, superiores às encontradas em Pederneiras.

Tabela 25 .

\begin{tabular}{|c|c|c|c|c|c|c|}
\hline & População & $\mathrm{FF}$ & $\mathrm{DAP}(\mathrm{cm})$ & ALT (m) & $\mathrm{VC}\left(\mathrm{m}^{3} / \mathrm{ha}\right)$ & SOB $(\%)$ \\
\hline \multirow{5}{*}{$\mathrm{PE}$} & Campinas & 1,81 & 13,37 & 9,59 & 265,05 & 83,3 \\
\hline & Ibicatu & 1,73 & 12,72 & 9,36 & 238,38 & 80,6 \\
\hline & Vassununga & 1,66 & 12,07 & 8,99 & 210,04 & 74.7 \\
\hline & Média $(\bar{x})$ & 1,73 & 12,72 & 9,31 & 238,08 & 79,1 \\
\hline & IMA & $\ldots$ & 0,75 & 0,55 & 14,00 & -..- \\
\hline
\end{tabular}

Págỉna 152 - Penúltima linha: genitores ao invés de progenitores

Página 164 - Terceiro parágrafo, última linha: crescimentos e não ganhos. 


\title{
Dacios Internacionais de Catalogação na Publicação (CIP) DIVISÃO DE BIBLIOTECA E DOCUMENTAÇÃO - Campus "Luiz de Queiroz"/USP
}

\author{
Sebbenn, Alexandre Magno \\ Estrutura genética de populações de ]equitibá-Rosa [Cariniana legalis (Mrat.) O. Ktze] \\ por caracteres quantitativos e isoenzimas / Alexandre Magno Sebbenn. - - Piracicaba, 2001. \\ $210 \mathrm{p}$. \\ Tese (doutorado) - Escola Superior de Agricultura Luiz de Queiroz, 2001. \\ Bibliografia. \\ 1. Cruzamento vegetal 2. Genética quantitativa 3. Isoenzima 4. Jequitibá-rosa 5. \\ Meihoramento genético vegetal 6. População genética 7. Variabilidade genética I. Título
}

CDD 634.97342

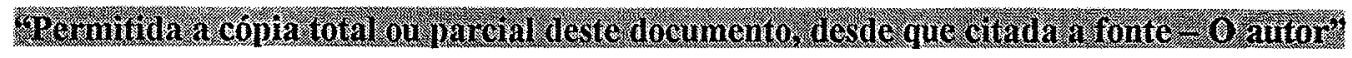

Datio deposito junto a CPG/ESALO

$26 / 06 / 2001$ 
Dedico

a minha família 


\section{Agradecimentos}

Agradeço:

Inicialmente, ao professor Paulo Yoshio Kageyama por sua orientação, amizade, apoio e por acreditar na minha capacidade de realizar este trabalho, ajudando-me a adquirir conhecimento na área de conservação e melhoramento florestal.

Ao professor Roland Vencovsky pela coorientação, valiosas discussões, amizade e grandes sugestões durante a realização deste trabalho.

Ao colega de pós-graduação e professor Alexandre Siqueira Guedes Coelho pela minuciosa leitura, valiosas críticas e discussões.

Ao Instituto Florestal de São Paulo, por mais uma vez acreditar na minha capacidade de fazer ciência, liberando-me exclusivamente para realizar este trabalho, em especial à duas pessoas, Dra. Ana Cristina de Franco Machado Siqueira e PqC Antonio Scatena Zanatto, pela amizade, apoio, liberação do ensaio para estudo e auxílio na tomada dos dados.

Á minha esposa Rita de Cássia Itália Rafael Sebbenn pela ajuda na coleta dos dados, leitura e paciência com a minha disciplina e determinação na realização deste estudo.

Aos colegas e grandes amigos Luciana e Ricardo (Dog) pela minuciosa leitura da tese.

Ao Conselho Nacional de Desenvolvimento Científico e Tecnológico (CNPq) pela concessão da bolsa de doutoramento e a Fundação de Apoio a Pesquisa do Estado de São Paulo (FAPESP) pelo financiamento do projeto (FAPESP $n^{\circ}$ 98/02448-7).

Também faço um agradecimento muito especial à técnica de laboratório Elza Martins Ferraz pelo seu auxílio, facilitando e apoiando meu trabalho no Laboratório de Genética e Reprodução de Espécies Arbóreas (LARGEA). 
Igualmente, ao técnico em agropecuária Gelson Dias Fernandes, por sua grande ajuda na liberação de material de campo, bem como pelo árduo trabalho de coleta de material para as análises de eletroforese.

Aos funcionários do Instituto Florestal de São Paulo que auxiliaram na coleta dos dados quantitativos e aos estagiários, Fernanda Gosser Brasso e Gabriel Bortoleto Bichuette, e à Técnica Márcia Patrícia Moreno pelo auxílio nas eletroforeses de isoenzimas.

Ao estudante de engenharia florestal Márcio Fedele (ESALQ/USP) e ao Biólogo Fernando Schimth, também pelo árduo trabalho de coleta de campo.

A bibliotecária Silvia Zinsly (Biblioteca Central da ESALQ/USP), pela simpatia e valiosa correção nas referências bibliográficas.

Aos demais colegas de pós-graduação, professores e funcionários do Departamento de Genética, pelo convívio e amizade.

Finalmente, agradeço as demais pessoas que, de alguma forma, me ajudaram neste trabalho. 


\section{SUMÁRIO}

Pag.

RESUMO.................................................................................. ix

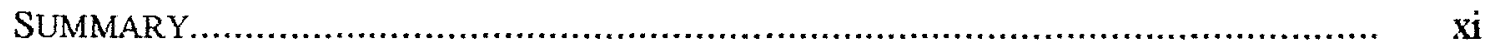

1 INTRODUÇÃ

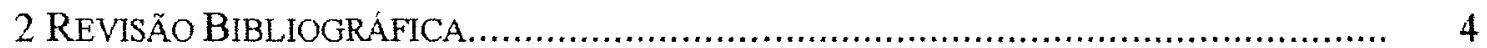

2.1 A Espécie Cariniana Legalis..(Mart.) O. Ktze........................................ 4

2.2 Conservação Genética................................................................. 5

2.3 Sistema de Reprodução........................................................... 9

2.4 Estrutura Genética de Populações................................................. 14

2.4.1 Conceitos, Causas e Características............................................... 14

2.4.2 Variabilidade Isoenzimática Versus CaracteresQuantitativos..................... 20

2.4.3 Quantificando a Estrutura Genética de Populações................................. 23

2.5 Depressão por Endogamia em Essências Florestais................................... 26

2.6 Estimativa de Parâmetros Genéticos em Progênies de Polinização Aberta........ 34

2.7 Componentes de Variância Genética na Presença de Sistema Misto de

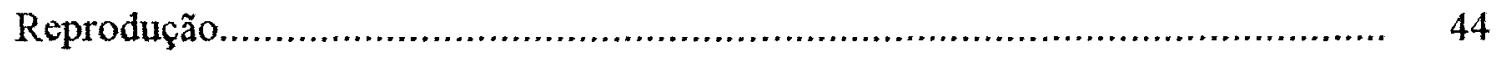

3 MATERIAL E MÉtODOS.................................................................... 55

31. Locais de Estudo....................................................................... 55

3.2 Delineamento Experimental................................................. 55

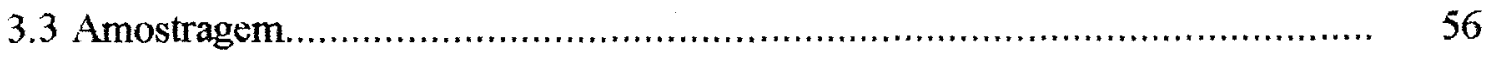

3.3.1 Caracteres Quantitativos.................................................... 56

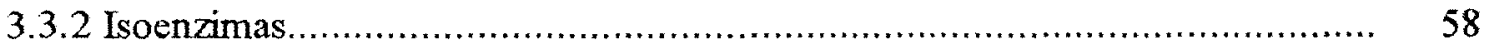

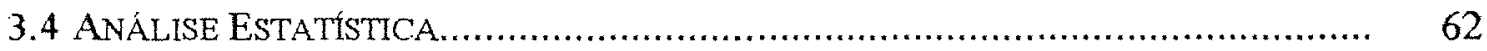

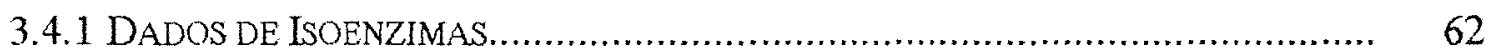




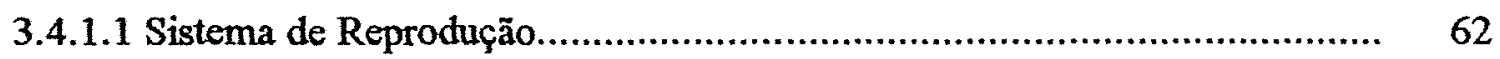

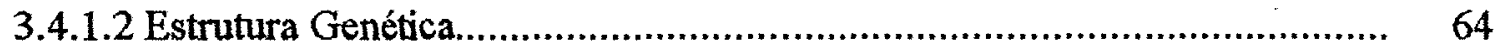

3.4.1.3 Variabilidade Genética Intrapopulacional........................................... 70

3.4.2 Caracteres Quantitativos........................................................................ 72

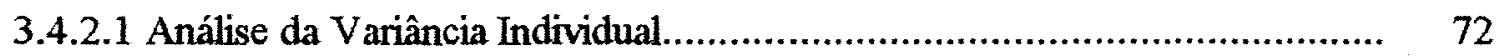

3.4.2.2 Análise da Variância Conjunta............................................................. 76

3.4.2.3 Decomposição da Interação em Partes Simples e Complexa...................... 79

3.4.3 Depressão Por Endogamia ................................................................. 80

3.4.4 Estimativa da Variância Genética Aditiva em Progênies de Polinização livre.. 83

3.4.5 Métodos de Seleção................................................................................ 85

3.4.5.1 Ïndice de Seleção Multi-Efeito............................................................ 86

3.4.5.2 Seleção Entre e Dentro de Progênies.................................................... 90

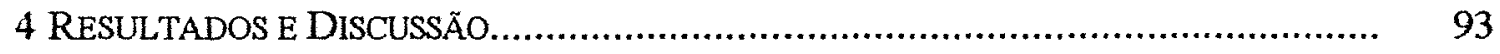

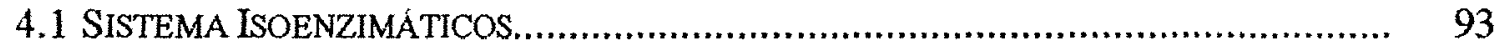

4.2 SISTEMA DE REPRODUÇÃO................................................................... 93

4.3 CRESCIMENTO E ADAPTAÇÃO DAS POPULAÇǑ́ES ............................................ 104

4.4 ESTRUTURA GENÉTICA......................................................................... 107

4.4.1 Caracteres Quantitativos.................................................................... 107

4.4.2 Dados de Isoenzimas........................................................................ 112

4.5 VARIABILIDADE GENÉTICA DENTRO DE POPULAÇOEES..................................... 117

4.5.1 Caracteres Quantitativos.................................................................... 117

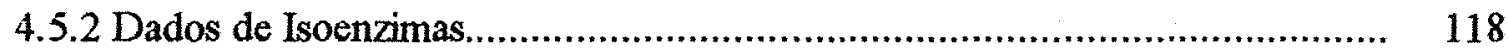

.4.6 CARACTERES QUANTTTATIVOS VERSOS ISOENZIMAS.................................... 121

4.7 DEPRESSÃO POR ENDOGAMIA............................................................... 124

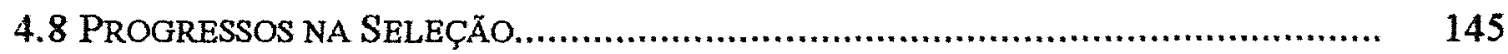

4.8.1 Coeficientes dos Componentes Quadráticos................................................ 145

4.8.2 Variância Genética Aditiva....................................................................... 147

4.8.3 Coeficientes de Herdabilidade................................................................ 149 


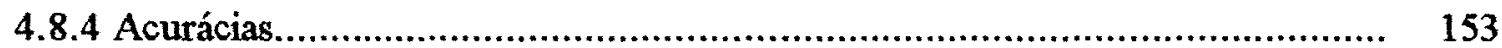

4.8.5 Correlaç̃̃es Genéticas, Ambientais e Fenotípicas.................................... $\quad 156$

4.8.6 Ganhos Preditos na Seleção.................................................................... 158

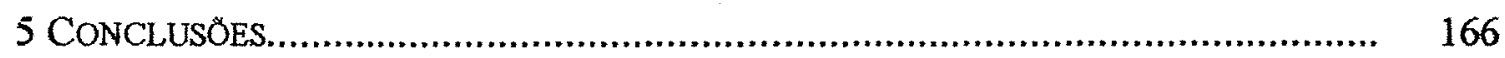

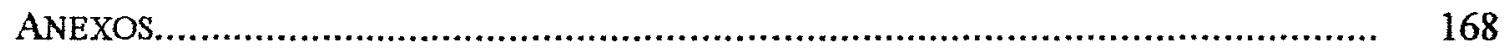

REFERENCIAS BIBLIOGRAFICAS................................................................ 183 


\section{RESUMO}

AUTOR: AlEXANDRE MAGNo SEBBENN ORIENTADOR: Prof. DR. PAUlo Yoshio Kageyama

Esta tese detalha os resultados de 17 anos de experimentação com progênies e populações de Cariniana legalis (Mart.) O. Ktze, instalada em dois locais do Estado de São Paulo (Estação Experimental de Luiz Antonio e Estação Experimental de Pederneiras), no delineamento de blocos de famílias compactas, para fins de sua conservação ex situ. Foram amostradas três populações naturais da espécie (Pop. Campinas, Ibicatu e Vassununga), representadas por 16 a 22 progênies/população; mensurados cinco caracteres quantitativos: forma do fuste, DAP, altura total, volume cilíndrico e sobrevivência, aos 17 anos de experimentação e avaliados aproximadamente $1 / 3$ dos indivíduos totais ensaiados por 14 locos polimórficos distribuídos em 9 sistemas isoenzimáticos. A espécie é predominantemente alógama, com $\hat{t}_{m}$ variando de 91 a $99 \%$, porém, praticando um certa taxa de autofecundação (máximo 10\%), cruzamento entre aparentados (máximo 9\%) e preferenciais, resultando em progênies compostas por misturas de meios irmãos, irmãos completos e indivíduos de autofecundação. Os caracteres paresentaram melhor desempenho na E. E. de Luiz Antonio, devido principalmente às características do solo e ao desbaste realizado na idade de 8 anos de experimentação, neste local. A população Campinas apresentou o melhor desempenho em ambos os locais. A divergência genética entre populaçōes foi baixa, tanto para os caracteres quantitativos como para as isoenzimas, mostrando que a maior parte da variabilidade genética encontra-se dentro das populações. A análise da variância revelou moderados níveis de variabilidade genética entre progênies/populações, para as três populações. Contudo, as isoenzimas revelaram heterozigosidades altas e similares para as 
populações $\left(\hat{H}_{\circ}\right.$ variou de 0,263 a 0,283 e $\hat{H}_{e}$ de 0,348 a 0,366$)$. Foram também detectados excessos de homozigotos nas progênies, em relação ao esperado pelo Equilíbrio de Hardy Weinberg (EHW) ( $\hat{f}$ variando de 0,220 a 0,249$)$. $O$ agrupamento dos indivíduos de cada população em cinco classes de crescimento para o caráter DAP e a respectiva estimativa da heterozigosidade observada e índice de fixação destes grupos, evidenciou a tendência do aumento do crescimento com o aumento da heterozigosidade e redução na endogamia, sugerindo seleção para heterozigotos. Todavia, uma análise entre as freqüências alélicas dos cinco grupos indicou que a endogamia detectada é função do sistema de reprodução, sugerindo por sua vez, que os individuos de menor desempenho seriam o resultado da depressão por endogamia. A comparação dos ganhos preditos na seleção pelo método de seleção índice multi-efeitos e seleção entre e dentro de progênies, a partir do modelo de cruzamentos aleatórios e do modelo de reprodução mista com e sem parentesco entre os genitores, revelou que os ganhos ficaram superestimados em aproximadamente $20 \%$ para os dois métodos de seleção, quando foi utilizado o modelo de reprodução aleatório ao invés do modelo de reprodução mista sem parentesco e na ordem de $15 \%$ quando foi considerado o parentesco entre os genitores. $O$ método de seleção indice multi-efeitos permitio maiores ganhos em relação à seleção entre e dentro de progênies. Finalmente, objetivando-se simultaneamente a conservação ex situ e a produção de sementes melhoradas da espécie, propõe-se que o ensaio de Pederneiras seja mantido intacto para a conservação, por incluir um número maior de progênies da população Vassununga e o ensaio de Luis Antonio seja submetido à seleção dentro das populações, com base no índice de seleção multi-efeitos, dando origem assim, a um "pomar de sementes por mudas" do tipo multi-populações. O rferito pomar será constituido pela combinação de três populações, onde populações e progênies de melhor desempenho contribuirão mais para as freqüências alélicas da população melhorada.

Palavras-Chave: Cariniana legalis; teste de progênies e populações; eletroforese de isoenzimas; sistema de reprodução; conservação ex situ; melhoramento florestal. 


\title{
SUMMARY
}

\author{
AUTHOR: ALEXANDRE MAGNO SEBBENN \\ AdViser: Prof. Dr. Paulo Yoshio KageYama
}

This thesis details the results of a 17 year old experiment with progenies and populations of Cariniana legalis (Mart.) O. Ktze, implanted in a compact family block design, aiming at ex situ conservation, in two localities in São Paulo State (Luiz Antonio and Pederneiras Experimental Stations). Three natural populations were sampled, represented by 17 progenies from the Campinas population, 16 from Ibicatu and 22 from Vassununga. Five quantitative traits were measured: stem shape, diameter at breast height $(\mathrm{DBH})$, cylindrical volume and survival. In addiction, approximately one third of all individuals were assayed for 14 polymorphic loci distributed in nine isozyme systems. This species is predominantly alogamous with $\hat{t}_{m}$ rate variation 0.91 to 0.99 ), but it practices some self-fertilization (maximum 0.10), some biparental outcrossing (maximum 0.9) and some preferential outcrossing, which results in a mixture of half-sib, full-sib and self-sib progenies. Growth traits revealed differences among localities, with the best performance at Luis Antonio, because of soil structure and fertility and a tip treatment performed at 8 years. Campinas populations had the highest growth rates in both localities. Smaller genetic divergence among population existed for both quantitative traits and isozymes, and larger genetic variability was found within populations, especially among individuals within progenies. Moderate levels of genetic variability among progenies/populations was found for the three populations. However, isozymes revealed high heterozygosity values, although populations were similar $\left(\hat{H}_{o}: 0.263\right.$ to $0.283 ; \hat{H}_{e}: 0.348$ to 0.366$)$. In 
addiction, homozygosity excess in the progenies was detected, in relation to HardyWeinberg Equilibrium (EHW) expectations ( $\hat{f}: 0.220$ to 0.249 ). Similarty, growth rate increased of as heterozygosity increased and endogamy was reduced. When individuals from each population were grouped in five diameter classes this was evident, and the respective heterozygosity and inbreeding coefficients were estimated for each class. This suggested selection by heterozygosity. Nevertheless, an analysis among allelic frequencies among the frve groups indicated that the detected endogamy was a function of the mating system. Thus, individuals of lesser performance could be a result of endogamy depression. Comparison of the expected gain selection values given by a random mating model and by a mixed mating model revealed that the gains were overestimated in approximately $20 \%$ of the cases in the two methods of selection, when the random mating model instead of the mixed mating model was utilized. Comparing of selection methods, the multi-effects selection index gave higher gains in relation to within and among progenies method of selection. Finally, aiming at simultaneous genetic ex situ conservation and improvement, the Pederneiras test should be maintained intact for conservation purposes, because it included a larger number of Vassununga population progenies. The Luis Antonio test should be submitted to within populations selection, using the multi-effects index selection. This selection will result in a seed orchard of the multi-population type, consisting of a combination of three populations, where populations and progenies with the best performance will have a larger contribution to the allelic frequencies of the improved population.

KEY WORDS: Cariniana legalis; progenies and population trials; isoezymes electrophoresis, mating system; ex situ genetic conservation; genetic forest improvement. 


\section{INTRODUÇÃo}

Cariniana legalis ou Jequitibá-Rosa é uma das maiores árvores da floresta tropical húmida da América do Sul, chegando a atingir diâmetros superiores a 3 metros e alturas maiores que 40 metros. A espécie costuma ocorrer em pequenos grupos isolados, possivelmente constituindo-se de unidades panmíticas ou demes, estruturadas em familias. Apesar de ser possivel detectar vários exemplares de $C$. legalis, em seus locais de ocorrência natural, quando se considera sua área total de distribuição, verifica-se que a espécie é do tipo rara, com menos de 1 indivíduo por hectare.

No passado, quando as florestas eram contínuas, a espécie distribuáa-se em uma área ampla, que ia do Estado de São Paulo até os Estados de Alagoas e Pernambuco. Com a intensa devastação das florestas brasileiras, principalmente durante 0 século $\mathrm{XX}$, sobraram apenas algumas populações ou indivíduos isolados em áreas de preservação permanente, estações ecológicas e parques públicos, levando a $C$. legalis, já na década de 80, a entrar para a lista das espécies em extinção da FAO (Siqueira et al., 1986; Itoman et al., 1992; FAO, 1996).

Apesar disso, muito pouco tem sido feito para salvar a espécie da extinção. Não existe um programa especifico de conservação para a $C$. legalis. A conservação in situ tem sido realizada nas áreas públicas anteriormente citadas e existem poucas informações sobre a estrutura genética das populações naturais de $C$. legalis. No único estudo realizado, Harritt (1991) estudou duas populações naturais de C. legalis na Reserva Florestal da Companhia do Vale do Rio Doce, em Linhares, por isoenzimas. A autora observou baixo polimorfismo (30\%) e número médio de alelos por locos $(1,42)$, mas razoáveis níveis de heterozigosidade de acordo com o modelo de Hardy-Weinberg $(0,140)$. Também foram observados baixa divergência genética entre as populações $(0,053)$ e índices de fixação negativos para a espécie $(-0,053)$ e média das populações $(-$ 
0,113), sugerindo intenso fluxo gênico, alta taxa de cruzamento e seleçăo para heterozigotos, logo, alto potencial para a conservação in situ.

Por sua vez, a conservaçåo ex situ de $C$. legalis é restrita, abrangendo apenas três populações naturais, do Estado de São Paulo. Outra importante consideração, é que, apesar da espécie ter sido muito explorada para fins madeireiros, os reflorestamentos restringem-se a pequenos talhões de magnitude insignificantes, servindo mais para estudos silviculturais do que para produção e madeira. Ainda, absolutamente nada foi feito visando o melhoramento genético da espécie, sendo que a coleta de sementes continua sendo realizada em populações naturais.

Para a conservação e o melhoramento genético de uma espécie é fundamental o estudo do sistema de cruzamento e da estrutura genética de suas populações, visto que são estas informações que permitem o delineamento de estratégias para sua efetivação (Brown, 1978). Também é necessário combinar estudos isoenzimáticos, morfométricos e fisiológicos que descrevam a variabilidade genética entre e dentro das populaçóes da espécie de interesse (Hamrick, 1983).

Assim, dentro deste contexto, este estudo visa fornecer informações sobre o sistema de reprodução e estrutura genética de três populações de Cariniana legalis sob conservação ex situ, no Instituto Florestal de São Paulo. Para tanto, os padrões de estrutura e variabilidade genética foram acessados por caracteres quantitativos e isoenzimas. Este trabalho também objetiva comparar e mostrar como as informações genéticas obtidas por diferentes métodos podem ser complementares, facilitando o delineamento de estratégias de conservação e melhoramento de uma espécie. De forma mais específica, os objetivos foram:

1. Estudar o sistema de cruzamento de três populações naturais de $C$. legalis;

2. Quantificar e comparar a estrutura e a variabilidade genética de três populações de $C$. legalis através de caracteres quantitativos e isoenzimas;

3. Estimar os ganhos preditos na seleção, admitindo-se que as progênies de polinização aberta foram geradas por cruzamentos aleatórios e por cruzamento mistos; 
4. Propor estratégias que englobem tanto a continuidade do programa atual de conservação ex situ, como o início de um programa de melhoramento genético para a espécie, para fins de reflorestamentos comerciais e recuperação de áreas degradadas. 


\section{REVISÃo BIBLIOGRÁFICA}

\subsection{A ESPÉCIE Cariniana legalis (MART.) O. KTZE}

Cariniana legalis ocorre nos Estados do Espírito Santo, Rio de Janeiro, São Paulo, Minas Gerais, Mato Grosso, Bahia, Alagoas e Pernambuco, entre as latitudes $08^{\circ}$ S. a $23^{0} \mathrm{~S}$. (Corrêa, 1984), onde habita o estrato superior da Floresta Ombrófila Densa (Floresta Atlântica), Formação Baixo-Montana e Floresta Estacional Semidecidual (Carvalho, 1994). No Estado de São Paulo é comum na região da Serra da Mantiqueira e nos vales do Rio Mogi Guaçu e Pardo. Sua zona de ocorrência é o leste do Estado até as imediações da Capital, entretanto, não ocorre na região central e Oeste. Ela aparece tanto nos espigões como nas encostas, em solos rasos ou profundos, preferencialmente de boa qualidade, entre altitude de 30 e 1.000 metros (Nogueira, 1977; Carvalho, 1994), sendo comumente encontrada em densidades inferiores a 1,0 indivíduos por hectare (Harrith, 1991), logo, trata-se de uma espécie rara ( $\leq 1$ árvore por hectare).

A espécie é perenifolia a semicaducifolia com 10 a $25 \mathrm{~m}$ de altura e 60 a $100 \mathrm{~cm}$ de DAP, podendo atingir excepcionalmente 60 metros de altura e 4,0 metros de DAP (Carvalho, 1994). Na reserva de Ibicatu e Vassununga do Instituto Florestal de São Paulo, existem exemplares com alturas superiores a 40 metros e DAP superiores a 2,0 metros.

No Estado de São Paulo a floração da C. legalis ocorre de dezembro a março e os frutos amadurecem de maio a outubro. Detalhes da inflorescência, frutos e folthas podem ser encontrados em Itoman et al. (1992) e Carvalho (1994). As flores são hermafroditas, o fruto é seco, deiscente do tipo pixidio, apresentando de 10 a 15 sementes aladas. A polinização ocorre por abelhas e a dispersão é anemocórica. Seu ciclo de vida pode ultrapassar 500 anos de idade. No grupo sucessional a espécie apresenta característica de secundária tardia e no estágio sucessional não ocorre em pastagens, sendo 
essencialmente de floresta, onde ocorre em pequenos grupos, nas baixadas e encostas húmidas (Itoman et al, 1992; Carvalho, 1994).

C. legalis é semi-heliófita e em plantios tolera sombreamento leve a moderado durante os primeiros anos, não tolera frio quando jovem, tem boa capacidade de rebrotação da touça após o corte, podendo ser manejada por talhadia (Carvalho, 1994). A madeira é leve, cerne geralmente nas cores róseo-acastanhado, bege-rosado, bege-claro ou escuro, eventualmente com sombras pardacentas; superficie irregularmente lustrosa, textura média uniforme; grã direita ou irregular. É usada para tabuados em geral, carpintaria civil, artigos escolares, saltos de sapato, tonéis e mobiliário em geral (Mainieri, 1970). Nogueira (1977) ressalta que a sua madeira não é durável quando exposta ao tempo e tem aplicações semelhantes ao cedro (Cedrela fissilis), entretanto, apresenta qualidade inferior a esse.

Em relação à produtividade, nas florestas localizadas ao norte do Estado do Espírito Santo, o incremento médio anual (MMA) em volume de madeira foi estimado em $4,10 \mathrm{~m}^{3} / \mathrm{ha} /$ ano, sendo também observada grande variação em altura e DAP, nos plantios de $C$. legalis, sugerindo a possibilidade de ganhos com o melhoramento genético da espécie (Harritt, 1991). Contudo, atualmente, a C. legalis apresenta um reduzido número de exemplares em ocorrência natural, estando classificada como em perigo de extinção na categoria vulnerável, (Siqueira et al., 1986; Itoman et al., 1992; FAO, 1996), o que leva à necessidade imediata da adoção de práticas conservacionistas em relação à espécie.

\subsection{CONSERVAÇÃo GENÉTICA}

O valor do custo acarretado pela destruição das florestas naturais é desconhecido. Sabe-se, apenas, que o patrimônio florestal nativo contem uma abundância de recursos genéticos na flora e na fauna, e que, em alguns casos, estas florestas protegem os últimos indivíduos de certas espécies. O custo dessa perda é, provavelmente, muito alto, porque os avanços em medicina, ciências florestais, agronomia e química irão requerer sempre mais deste acervo de material genético (Griffith, 1987). A erosão genética ou perda de genes está ocorrendo com diferentes intensidades, conforme a espécie. Em vários casos, todavia, a situação atual parece ser já bastante crítica (Vencovsky, 1987). 
No Estado de São Paulo, o desenvolvimento da agricultura, agro-pecuária e da silvicultura de essências exóticas, se fez às custas da derrubada de extensas áreas de florestas naturais, tendo-se hoje apenas $7 \%$ da cobertura original. Tanto esses ciclos econômicos quanto o extrativismo de espécies de interesse econômico fez com que a biodiversidade fosse bastante reduzida, restrita hoje aos remanescentes de florestas situadas em unidades de conservação, mantidas pelo poder público (Siqueira \& Figliolia, 1998). No entanto, as pressões expansionistas do urbanismo e da agricultura continuam a ameaçar esses remanescentes, sendo importante a conservação genética de exemplares arbóreos que tenham valor atual ou futuro para a humanidade, em locais de garantida segurança (Griffith, 1987).

Os recursos genéticos florestais são unidades de variação herdadas de valor presente ou potencial futuro. A variação refere-se às diferenças na composição genética entre individuos ou grupos de indivíduos de uma mesma espécie (Keiding \& Graudal, 1989), sendo que sua redução diminui o potencial de ajuste das espécies às mudanças naturais (Frankel, 1977).

As práticas conservacionistas estão diretamente relacionadas com atividades para salvar e prevenir a perda de genes, de complexos gênicos e genótipos e, em outro extremo, prevenir a extinção de toda uma categoria taxonômica (Zobel \& Talbert, 1984).

Os princípios da conservação genética se baseiam na distribuição da variabilidade genética entre e dentro de populaçōes como condição essencial e insubstitúvel para a continuidade evolutiva das espécies (Frankel, 1977). Existem basicamente duas formas de conservação genética, a in situ e a ex situ. A conservação in situ consiste em manter as populações em seu ambiente natural e a ex situ fora de seu ambiente natural (Kegeyama, 1987; Griffith, 1987). A conservação in situ é a mais indicada porque conserva a espécie em seu ambiente natural, preservando também seu potencial evolutivo. Por sua vez, a conservação ex situ é uma alternativa no caso da impossibilidade da prática in situ (Dias \& Kageyama, 1991).

Para a efetiva conservação in situ é necessário o conhecimento científico da biologia reprodutiva, ecologia e padrão de distribuição das espécies envolvidas. Sem estas 
informações, não se tem a certeza do tamanho nem da configuração necessária para que as reservas possam garantir a sobrevivência das espécies florestais (Griffith, 1987).

O objetivo da conservação ex situ é manter amostras representativas de populações para que, após caracterizadas, avaliadas e multiplicadas, estejam disponíveis para o melhoramento genético e/ou pesquisas correlatas (Llheras, 1992).

A conservação ex situ com essências florestais é realizada principalmente em testes de progênies/procedências. Estes testes permitem avaliar a magnitude da variabilidade genética entre e dentro de populações e entre e dentro de progênies, dentro de populaçōes (Siqueira et al., 1986). Outras formas de conservação ex situ, como sementes e in vitro são difíceis e dificultam a recombinação do material no banco de germoplasma, tornando a prática, na maioria das vezes, inviável. Porém, quando passível de ser realizada, não deixa de ser uma alternativa (Llheras, 1992).

É importante ter-se em mente que as estratégias de conservação in situ e ex situ não são alternativas; são na verdade, formas complementares de conservar os recursos genéticos (Griffith, 1987; Keiding \& Graudal, 1989).

Uma medida muito importante a ser conhecida na conservação genética é o tamanho efetivo de populaçóes $\left(N_{e}\right) . O N_{e}$ representa o tamanho de uma população ou vizinhança que apresenta a mesma redução na variabilidade genética pela endogamia ou deriva de uma população de referência, panmítica de tamanho finito $N$ (Crow \& Kimura, 1970; Lande, 1988), ou seja, refere-se ao grau de representatividade genética presente $\mathrm{em}$ uma amostra $(n)$ de plantas, sementes ou propágulos.

Muito autores têm observado que o tamanho efetivo costuma ser inferior ao tamanho senso (número de plantas amostradas). $O$ tamanho efetivo depende principalmente dos níveis de endogamia e parentesco existentes na amostra, sendo que quanto maiores estes niveis, menor é a representatividade genética da amostra (Vencovsky, 1987). $\mathrm{O} N_{e}$ é afetado pelo número desigual de individuos masculinos e femininos, variação no tamanho das progênies, flutuações temporais no tamanho da população (Wright, 1969), sobreposição de gerações, presença de estruturação e endogamia dentro das populações, fertilidade diferencial na função masculina e feminina entre genótipos e assincronismo no florescimento (Loveless \& Hamrick, 1984; Lande, 
1988). Além destes fatores, a apomixia e a reprodução vegetativa também influencia o $N_{e}$. Tais fatores tornam o tamanho senso das populações $(N)$ diferentes do tamanho efetivo.

O tamanho efetivo pode ser estimado para várias situações, como por exemplo, para uma população de plantas adultas; uma população estruturada em progênies, várias populações, populações em várias regiões, acessos de um banco de germoplasma e etc. $O$ importante na estimativa do $N_{e}$ é que a população de referência esteja bem definida.

Com base em Vencovsky (1997), são apresentados a seguir, alguns exemplos de como o $N_{e}$ pode ser estimado.

$1^{0}$ Exemplo: estimativa do $N_{e}$ para indivíduos adultos de uma simples população:

$$
N_{e}=\frac{n}{1+f}
$$

onde $n$ é o tamanho físico da amostra e $f$ o índice de fixação. Para esta estimativa é necessário admitir ausência de parentesco entre individuos amostrados $(n)$ e que os genes são correlacionados apenas dentro de indivíduos. Desta forma, fica claro que o $N_{e}$ é afetado apenas pelo índice de fixação.

$2^{0}$ Exemplo: estimativa do $N_{e}$ para progênies maternas de uma simples população:

$$
N_{e}=\frac{0,5}{\theta_{f}\left(\frac{1+C_{f}}{m}-\frac{1}{n}\right)+\frac{1+F}{2 n}}
$$

Onde o $\theta_{f}$ é a coancestria entre individuos dentro de progênies ou a divergência genética entre progênies, $m$ é o número de parentais ou de progênies avaliadas, $n$ é o número total de indivíduos avaliados nas progênies $\left(n=\sum n_{l}\right) ; C_{f}$ é o quadrado do coeficiente de variação do número de indivíduos $\left(n_{i}\right)$ avaliados nas progênies $(i=1,2, \ldots, f)$ e $F$ é o índice de fixação para o conjunto das progênies.

$3^{0}$ Exemplo: estimativa do $N_{e}$ para várias populações: 


$$
N_{e}=\frac{0,5}{\theta_{P}\left(\frac{1+C_{P}}{m}-\frac{1}{n}\right)+\frac{1+F}{2 n}}
$$

Onde o $\theta_{P}$ é a coancestria entre indivíduos dentro de populações ou divergência genética entre populações, $m$ é o número de populações avaliadas, $n$ é o número total de indivíduos avaliados nas populações $\left(n=\sum n_{i}\right), C_{P}$ é o quadrado do coeficiente de variação de $n_{i}$ sobre as populações $(i=1,2, \ldots . ., m)$ e $F$ é o índice de fixação para o conjunto das populações.

O $N_{e}$ também é de grande importância para delimitar a área mínima viável para conservação in situ, de uma espécie (Sebbenn, 1997). Contudo, um ponto que tem sido muito discutido entre geneticistas é o $N_{e}$ ideal para a conservação de uma espécie. Dentro deste contexto, Frankel \& Soulé (1981) sugerem que um $N_{e}$ de 50 já é suficiente para prevenir a perda de alelos raros em poucas geraçóes e de 500 para a conservação de alelos raros a longo prazo.

Finalmente, na conservação de essências florestais, no Brasil, destaca-se o Instituto Florestal de São Paulo (IFSP). O IFSP conta hoje com um banco de conservação ex situ constituído por aproximadamente 30 espécies representando várias progênies e populações (Gurgel Garrido, 1997). A conservação é feita em delineamentos experimentais como blocos ao acaso e blocos de famílias compactas, permitindo assim, o monitoramento constante da variabilidade genética e do comportamento silvicultural das espécies.

\subsection{SISTEMA DE REPRODUÇÃo}

O sistema de reprodução de uma espécie determina como as informaçðes genéticas são transferidas de uma geração para a outra (Wright, 1921), podendo influenciar fortemente o potencial de recombinação da população (Allard, 1971). Logo, o sistema de reprodução determina em parte a estrutura genética espacial e temporal da espécie (Ritland \& Jain, 1981; Brown, 1989; Murawski et al., 1994). Devido a isso, e considerando que a efetivação de um programa de conservação e melhoramento genético 
depende do conhecimento da estrutura genética das populações é importante obter-se informações acuradas do sistema de reprodução.

Em populações de plantas estas informações não podem ser obtidas por observaçōes diretas, devido à dificuldade de traçar-se a origem do fluxo de pólen entre e dentro de indivíduos (Schoen \& Clegg, 1984). Por isso, o sistema de reprodução tem sido muito estudado com base em dados de marcadores bioquímicos e moleculares combinados com elaborados modelos genéticos-estatísticos (Clegg, 1980).

Sabe-se hoje que as espécies arbóreas apresentam uma ampla variedade de sistema de reprodução, incluindo cruzamentos, autofecundação, apomixia e combinaçð̃es destas. No entanto, inicialmente acreditava-se que as espécies arbóreas tropicais fossem autocompativeis e, praticavam principalmente autofecundação (Federrof, 1966). Posteriormente, estudos de Bawa (1974), Ashton (1976) e Bawa et al. (1985) mostraram a predominância de fecundação cruzada e fortes pressões seletivas para a manutenção da diversidade genética das espécies arbóreas tropicais. Bawa (1974), estudando o sistema de reprodução em espécies arbóreas tropicais na floresta tropical semidecídua da Costa Rica, através de polinização controlada e observações da biologia floral, verificou que, de 130 espécies, $14 \%$ eram autocompatíveis, $54 \%$ auto-incompatíveis, $68 \%$ hermafroditas, $22 \%$ dióicas e $10 \%$ monóicas. Os resultados de Bawa mostraram claramente as estratégias adotadas pelas espécies arbóreas para evitar a autofecundação e forçar o cruzamento, logo a recombinação, permitindo desse modo, a manutenção de alta variabilidade genética nas populações.

Como em populaçõos de espécies alógamas, todas as plantas apresentam locos em heterozigose, provavelmente, muito da carga genética presente é mascarada por estes locos, sendo que a autofecundação gera endogamia e, quase sem exceção, resulta em deterioração geral do vigor, bem como o aparecimento de outros efeitos adversos (Allard, 1971). Possivelmente, é por esta razão que a auto-incompatibilidade e outros mecanismos de exocruzamento evoluíram em numerosas espécies de plantas. Se uma população já se tornou altamente endogâmica, a depressão por endogamia é recuzida porque muito da carga mutacional terá sido expurgada pela seleção natural. Assim, os alelos para a autocompatibilidade ou autofecundação podem ser desvantajosos em grandes populações 
com reprodução por cruzamentos, mas vantajosos em pequenas populações endogâmicas (Futuryma, 1992).

O sistema de reprodução das espécies arbóreas pode ser caracterizado basicamente por dois modelos: o modelo aleatório e o modelo misto de reprodução. Cabe ressaltar que existem outros modelos como o de autofecundação efetiva $e o$ de cruzamentos biparentais (Schoen \& Clegg, 1984), no entanto, de menor aplicação em essências florestais.

O modelo de cruzamentos aleatórios é o modelo do Equilíbrio de Hardy-Weinberg (Tabela 1). Este modelo é o mais comum e abstrai o problema essencial da transmissão das informações genéticas em populações, ou como a distribuição das frequências gênicas surgem de uma geração para outra. Seu grande valor em populações experimentais é que a pressuposição de cruzamentos aleatórios serve como padrão de referência, permitindo a comparação com os cruzamentos observados (Clegg, 1980).

$\mathrm{O}$ modelo de reprodução mista divide o processo de reprodução em dois componentes: cruzamentos aleatórios e autofecundação (Brown \& Allard, 1970; Clegg, 1980; Ritland \& Jain, 1981; Schoen \& Clegg, 1984). Este modelo é o mais difundido para a avaliação do sistema de reprodução em plantas a partir de dados de marcadores genéticos (Clegg, 1980). A partir deste modelo, a taxa de cruzamento $t$ pode ser estimada por dois métodos: o primeiro método, baseado no Equilibrio de Endogamia de Wright EEW (Jain, 1979; Vencovsky, 1994; Weir, 1996) e o segunda, baseado nos genótipos multilocos observados em progênies de mãe conhecida (Brown \& Allard, 1970; Ritland \& Jain, 1981). A estimativa de $t$ pelo método de EEW pode ser obtida por dois métodos de estimação: o método dos momentos (Jain, 1979; Vencovsky, 1994; Weir, 1996) e o de máxima verossimilhança (Weir, 1996). Pelo método dos momentos, a taxa de cruzamento $(t)$ e de autofecundação $(s)$ pode ser estimada pela expressão:

$$
\begin{aligned}
& t=\frac{(1-f)}{(1+f)}, \\
& s=1-t,
\end{aligned}
$$

onde: $f$ é o índice de fixação ou coeficiente de endogamia. A pressuposição de EEW garante que toda a endogamia observada pode ser atribuída aos efeitos do sistema de reprodução, ou seja, autofecundação e cruzamento entre aparentados. $\mathrm{Na}$ ausência de $\mathrm{EEW}$, os valores de $f$ tornam-se independentes de $s$, podendo assumir qualquer valor, 
inclusive negativo, caso esteja ocorrendo seleção para heterozigotos nas populações. Em tais situações, o coeficiente de endogamia passa a ser influenciado também por fatores evolutivos como seleção, mutação, deriva e migração, e $t$ perde o valor como estimador dos efeitos do sistema de reprodução. Assim, para se estimar a taxa de cruzamento pelo método dos momentos é necessário previamente submeter-se os locos ao teste de EEW (Tabela 1), descartando-se os que apresentarem desvios deste modelo.

Tabela 1. Freqüências genotípicas esperadas no Equilíbrio de Hardy-Weinberg e de Endogamia de Wright, para o caso de locos com três ou mais alelos. (Compilado de Reis, 1996).

Freqũências genotípicas esperadas

\begin{tabular}{ccc}
\cline { 2 - 3 } Genótipos & Eq. de Hardy-Weinberg & Eq. de Endogamia de Wright \\
\hline$A_{2} A_{1}$ & $p_{1}^{2}$ & $p_{1}^{2}+p_{1}\left(1-p_{1}\right) f$ \\
$A_{4} A_{2}$ & $2 p_{1} p_{2}$ & $2 p_{1} p_{2}(1-f)$ \\
$A_{1} A_{3}$ & $2 p_{1} p_{3}$ & $2 p_{1} p_{3}(1-f)$ \\
$A_{2} A_{2}$ & $p_{2}^{2}$ & $p_{2}^{2}+p_{2}\left(1-p_{2}\right) f$ \\
$A_{2} A_{3}$ & $2 p_{2} p_{3}$ & $2 p_{2} p_{3}(1-f)$ \\
$A_{3} A_{3}$ & $p_{3}^{2}$ & $p_{3}^{2}+p_{3}\left(1-p_{3}\right) f$ \\
$A_{1} A_{n}$ & $2 p_{1} p_{n}$ & $2 p_{1} p_{n}(1-f)$ \\
$A_{2} A_{n}$ & $2 p_{2} p_{n}$ & $2 p_{2} p_{n}(1-f)$ \\
$A_{3} A_{n}$ & $2 p_{3} p_{n}$ & $2 p_{3} p_{n}(1-f)$ \\
$A_{n} A_{n}$ & $p_{n}^{2}$ & $p_{n}^{2}+p_{n}\left(1-p_{n}\right) f$ \\
\hline
\end{tabular}

$p_{n}$ : Frequêencia do alelo $n$ na população.

Já, para o método $t$ multilocos, as estimativas são obtidas apenas por máxima verosimilhança (Ritland \& Jain, 1981). O modelo de cruzamento misto de Ritland \& Jain (1981) admite que as populações reproduzem-se por autofecundação a uma taxa $s$ e por cruzamentos aleatórios a uma taxa $t$ (Ritland \& Jain, 1981; Hamrick, 1989; Ritland, 1990). As pressuposiçōes básicas para a sua aplicação são: (1) que os genótipos foram gerados por cruzamentos aleatórios ou autofecundação; (2) que as frequências alélicas do pólen são homogêneas para todos os cruzamentos com os genótipos maternos; (3) que a 
taxa de cruzamento é independente do genótipo materno; e (4) que não existe seleção atuando nos marcadores entre o período de cruzamento e a avaliação genética das progênies (Ritland \& Jain, 1981; Ritland, 1990). Em resumo, estas pressuposições admitem que o marcador é neutro, que todos os indivíduos têm a mesma probabilidade de autofecundação e cruzamento, sendo a taxa de cruzamento e autofecundação homogêneas nas plantas. No entanto, Hamrick (1989) afirma que estas suposições não condizem muitas vezes com as características naturais das populações das plantas.

Baseado no modelo de cruzamento misto de Ritland \& Jain (1981), Ritland (1990) desenvolveu um programa de computador para a estimativa da taxa de cruzamento. $O$ programa, denominado de "multilocos $t$ ", permite estimar: 1) a taxa de cruzamento multilocos $\left.\left(\hat{t}_{m}\right) ; 2\right)$ a taxa de cruzamento unilocos $\left.\left(\hat{t}_{s}\right) ; 3\right)$ o coeficiente de endogamia dos genótipos maternos $(\hat{f}) ; 4)$ a freqüência gênica do pólen $(p)$ e dos óvulos $(o) ; 5)$ a taxa de cruzamento entre aparentados $\left.\left(\hat{t}_{p}=\hat{t}_{m}-\hat{t}_{s}\right) ; 6\right)$ a correlação de paternidade $\left(\hat{r}_{p}\right)$ e, 7) a correlação de autofecundação $\left(\hat{r}_{s}\right)$. O programa pode também computar estimativas de $t \mathrm{e}$ $s$ para cada progênie. Algumas destas estimativas são apresentadas na Tabela 2 (ver também Tabelas 49 a 52), para espécies arbóreas tropicais, espécies do gênero Eucalyptus, gênero Pinus e outras Gimnospermas, respectivamente.

Tabela 2. Taxa de cruzamento unilocos $\left(\hat{t}_{s}\right)$, multilocos $\left(\hat{t}_{m}\right)$, entre aparentados $\left(\hat{t}_{p}\right)$ e de autofecundação $(\hat{S})$ para média de várias espécies arbóreas.

\begin{tabular}{lccccc}
\hline Espécies & $n e$ & $\hat{t}_{s}$ & $\hat{t}_{m}$ & $\hat{t}_{p}$ & $\hat{s}$ \\
\hline Angiospermas - Arbóreas tropicais & 49 & 0,822 & 0,880 & 0,059 & 0,120 \\
& & {$[ \pm 0,052]$} & {$[ \pm 0,040]$} & {$[ \pm 0,091]$} & {$[ \pm 0,042]$} \\
Angiospermas -Eucalyptus sp. & 18 & 0,650 & 0,754 & 0,104 & 0,246 \\
& & {$[ \pm 0,165]$} & {$[ \pm 0,089]$} & {$[ \pm 0,015]$} & {$[ \pm 0,123]$} \\
Gimnospermas - Pinus sp. & 16 & 0,880 & 0,874 & $-0,006$ & 0,126 \\
& & {$[ \pm 0,159]$} & {$[ \pm 0,100]$} & {$[ \pm 0,025]$} & {$[ \pm 0,094]$} \\
Outras Espécies Arbóreas & 12 & 0,811 & 0,792 & $-0,019$ & 0,208 \\
& & {$[ \pm 0,190]$} & {$[ \pm 0,150]$} & {$[ \pm 0,052]$} & {$[ \pm 0,153]$} \\
Espécies arbóreas & 95 & 0,800 & 0,851 & 0,051 & 0,149 \\
& & {$[ \pm 0,045]$} & {$[ \pm 0,035]$} & {$[ \pm 0,019]$} & {$[ \pm 0,036]$} \\
\hline
\end{tabular}

ne: Número de espécies; [ ]: Intervalo de confiança a $95 \%$ de probabilidade. 
Na Tabela 2, é evidente a predominância de cruzamentos nas espécies arbóreas. $\mathrm{Na}$ média, os grupos mostram-se como de reprodução mista, predominantemente alógamas.

A constatação de que muitas espécies arbóreas apresentam sistema misto de reprodução é de grande importância na conservação e no melhoramento florestal. Considerando que os modelos clássicos utilizados no melhoramento florestal admitem, na grande maioria das vezes, que as espécies arbóreas são alógamas, sem parentesco e endogamia na geração parental, pode-se pressupor que esta seja uma das principais causas dos erros nas predições de ganhos na seleção, juntamente com a interação genótipos ambientes.

Finalmente, o sistema de reprodução por cruzamentos aleatórios prediz alta variabilidade genética e heterozigosidade dentro de populações, reduzidos níveis de divergência genética entre populações, devido ao intenso fluxo de pólen entre populações e grandes tamanhos efetivos $\left(N_{e}\right)$ e de vizinhança $\left(N_{b}\right)$, com reduzida subdivisão dentro de populações. O sistema misto de reprodução prediz variabilidade genética intermediária entre espécies de autofecundação e de reprodução aleatória, potencial para a diferenciação entre populações, dependendo do nível de autofecundação, podendo variar no tempo e potencial para a subdivisão dentro de populações, dependendo do balanço entre autofecundação e cruzamentos (Loveless \& Hamrick, 1984).

\subsection{Estrutura Genética de Populações}

\subsubsection{Conceitos, Causas e Características}

Estrutura genética é a forma como a variabilidade genética é distribuída entre e dentro dos níveis hierárquicos de subdivisão de uma espécie (Brown, 1978). Esta estrutura pode ser manifestada entre distintas populações geográficas, dentro de um grupo local de plantas ou mesmo em grupos de progênies (Loveless \& Hamrick, 1984). Ela pode ser definida como a distribuição não aleatória de alelos e genótipos (Hamrick, 1987). $O$ desenvolvimento e a manutenção da estrutura genética ocorrem devido às interações de um conjunto complexo de fatores evolucionários, como variação no conjunto gênico; organização desta variação dentro de genótipos; distribuição espacial dos genótipos; sistema de reprodução que controla a união dos gametas para a formação das progênies; 
dispersão das progênies; seleção; deriva; mutação; eventos casuais; e processos de crescimento, mortalidade e reposição dos indivíduos, que darão, origem às populações futuras (Clegg, 1978; Hamrick, 1983; Loveless \& Hamrick, 1984; Hamrick, 1989; Alvarez-Buylla \& Garay, 1994). De importância primária é a seleção, o tamanho efetivo populacional e a habilidade da espécie de dispersar pólen e sementes (Hamrick, 1983). Em geral, a diferenciação entre as populações é aumentada pela seleção e deriva genética. Por outro lado, espécies com intenso movimento de pólen e sementes têm menor diferenciação do que espécies com fluxo gênico restrito (Hamrick, 1989).

A estrutura genética pode estar associada a distribuição espacial ou temporal dos genótipos (Brown, 1978; Loveless \& Hamrick, 1984; Hamrick, 1989). A estrutura espacial refere-se à distribuição espacial dos individuos, sendo característica de cada espécie e determinada principalmente pelo sistema de reprodução e pelos padrões de dispersão de sementes, pólen e propágulos. De acordo com esses padrões, juntamente com seu histórico de vida, como eventos de colonização, migração e extinção, uma espécie pode desenvolver uma estrutura espacial agrupada de indivíduos dentro de populações, dando origem à subpopulações ou demes, caracterizadas por um maior grau de parentesco dentro dos grupos do que entre os grupos. Já, a estrutura genética temporal refere-se à subdivisão de gerações, por exemplo, entre pais e filhos, plântulas e jovens, jovens e adultos, ou ainda, pode referir-se às diversas gerações contidas em um banco de sementes ou de germoplasma.

$\mathrm{O}$ estudo da variação genética em populações naturais de uma espécie envolve basicamente duas questões. A primeira é descrever os níveis de variação genética mantidos dentro das populações ou espécies (Hamrick, 1983). Tais estudos podem ser realizados com base em dados de marcadores genéticos. Neste caso, a variabilidade genética intrapopulacional é quantificada em termos de número de alelos por locos $(\hat{A})$, porcentagem de locos polimórficos $(\hat{P})$, heterozigosidade observada $\left(\hat{H}_{o}\right)$, heterozigosidade esperada segundo as expectativas do Equikibrio de Hardy-Weinberg $\left(\hat{H}_{e}\right)$ e índice de fixação $(\hat{f})$ (Hamrick, 1983; Berg \& Hamrick, 1997). Estudos têm mostrado que a variação genética isoenzimática difere entre espécies e grupos taxonômicos e que a variação dentro das populações está associada às características dos 
históricos de vida das espécies, como por exemplo, distribuição geográfica, sistema de reprodução, tempo de fecundidade e mecanismos de dispersão de pólen e sementes (Brown, 1978; Hamrick et al., 1979; Hamrick, 1983; Hamrick \& Godt, 1989; Hamrick, 1989). Também tem sido verificado que a variabilidade isoenzimática para espécies arbóreas tropicais é maior que para a média das espécies arbóreas (Tabela 3) e plantas anuais (Hamrick, 1983).

Outra forma de quantificar a variação genética dentro das populações, é a partir de ensaios de campo (testes de progênies). Neste caso, tem-se feito o uso do coeficiente de variação genética. Em ensaios de campo, também é possível conhecer a herança dos caracteres adaptativos como altura, diâmetro, forma e sobrevivência, com base nos coeficientes de herdabilidade, em especial o coeficiente de herdabilidade em nivel de média de plantas. Em essências florestais nativas brasileiras, têm-se observado que caracteres de crescimento, como altura e DAP apresentam níveis moderados de herança, a julgar pelo coeficiente de herdabilidade no sentido restrito em nível de plantas $\left[\hat{h}_{i}=0,32\right.$ $( \pm 0,13), 0,22( \pm 0,14)$, respectivamente] e de variação genética, a julgar pelo coeficiente de variação genético $\left[C \hat{V}_{z}=7,5 \%( \pm 2,48 \%), 7,9 \%( \pm 2,65 \%)\right.$, respectivamente] (ver em anexo Tabela 53]. No entanto, é fato que a maior parte da variação fenotípica encontra-se entre individuos dentro de progênies $\left[C \hat{V}_{d}=25,4 \%( \pm 6,16 \%)\right.$ para altura e $35,1 \%( \pm 8,81 \%)$ para DAP $)]$. O problema é que por meio de caracteres quantitativos não é possível separar os efeitos genéticos dos ambientais da variação fenotípica dentro de progênies, mas predições teóricas sugerem níveis de variância genética superiores até aos encontrados entre progênies de meios irmãos, dado que, neste caso, tem-se a combinação de efeitos aditivos $\left(3 / 4 \sigma_{A}^{2}\right)$ e de dominância $\left(1 \sigma_{D}^{2}\right)$.

A segunda questão é de particular importância para a conservação genética, visto que se refere a maneira pela qual a variabilidade genética é partida entre e dentro de populações. Para um manejo racional dos recursos genéticos de uma espécie é necessário entender como a variação genética é distribuída e quais as características do ambiente ou da espécie que influenciam esta distribuição (Hamrick, 1983). 
A distribuição da variação genética em espécies de plantas pode ser influenciada pelo tamanho da população, distribuição geográfica da espécie, modo primário de reprodução (assexual, sexual, ambos), sistema de reprodução (autofecundação, cruzamento, sistema misto), mecanismos de dispersão das sementes e pólen (fluxo gênico) e tipo de comunidade em que a espécie comumente ocorre. Quatro destes fatores (tamanho da população, modo de reprodução, sistema de reprodução e dispersão das sementes) influenciam o tamanho efetivo das populações. Espera-se que espécies com grandes populações, sistema misto de reprodução, mecanismos eficientes de dispersão de sementes e pólen (Tabela 4), apresentem alta variação genética dentro das populaçð̃es e baixa entre. Já, para as espécies com pequenas populações, de autofecundação e/ou reprodução vegetativa, com limitada dispersão de pólen e sementes, espera-se uma baixa variabilidade dentro e alta entre as populações (Loveless \& Hamrick, 1984; Hamrick \& Schnabel, 1985; Hamrick \& Loveless, 1986).

Tabela 3. Número de locos $(n I)$, porcentagem de locos polimórficos a $95 \%$ de probabilidade $(\hat{P})$, heterozigosidade observada $\left(\hat{H}_{o}\right)$ e esperada $\left(\hat{H}_{e}\right)$ para algumas espécies arbóreas.

\begin{tabular}{|c|c|c|c|c|c|}
\hline Espécie & $n l$ & $\hat{P}$ & $\hat{H}_{0}$ & $\hat{H}_{e}$ & Autor \\
\hline $\begin{array}{l}\text { Espécies arbóreas } \\
\text { Espécies arbóreas tropicais }\end{array}$ & $\begin{array}{l}- \\
--\end{array}$ & $\begin{array}{l}50,0 \\
36,8\end{array}$ & $\cdots$ & $\begin{array}{l}0,142 \\
0,211\end{array}$ & $\begin{array}{l}\text { Hamrick et al (1979) } \\
\text { Hamrick et al. (1979) }\end{array}$ \\
\hline Bowdichia virginoides & 5 & 46,5 & - & 0,129 & Harritt (1991) \\
\hline Cariniana legalis ${ }^{\circ}$ & 6 & 48,8 & -.. & 0,146 & Harritt (1991) \\
\hline Chorisia speciosa & 7 & 77,8 & 0,245 & 0,284 & Souza (1997) \\
\hline Cordia trichotoma ${ }^{a}$ & 6 & 46,2 & -.. & 0,185 & Harritt (1991) \\
\hline Couratari guianensis & 8 & 100 & 0,203 & 0,429 & Lepsch-Cunha (1996) \\
\hline Couratari multiflora & 8 & 100 & 0,359 & 0,436 & Lepsch-Cunha (1996) \\
\hline Joannesia princeps ${ }^{\circ}$ & 6 & 51,2 & -.. & 0,140 & Harritt (1991) \\
\hline Machaerium vilolsum ${ }^{a}$ & 9 & 94,4 & 0,294 & 0,314 & Giudice Neto (1999) \\
\hline Média ${ }^{b}$ & & $\begin{array}{c}70,6 \\
{[+20,9]}\end{array}$ & $\begin{array}{c}0,275 \\
{[ \pm 0,107]}\end{array}$ & $\begin{array}{c}0,258 \\
{[ \pm 0,106]}\end{array}$ & \\
\hline
\end{tabular}

a: Média para duas populaçóes; b: Média só das espécies; [ ]: Intervalo de confiança a $95 \%$ de probabilidade. 
Tabela 4. Relação entre características do histórico de vida e distribuição da variabilídade genética total $\left(\hat{H}_{\tau}\right)$, dentro $\left(\hat{H}_{S}\right)$ e entre $\left(\hat{G}_{S T}\right)$ as populações naturais de plantas. Alterado de Hamrick (1983).

\begin{tabular}{lcccc}
\hline \multicolumn{1}{c}{ Características } & $n e$ & $\hat{H}_{T}$ & $\hat{H}_{s}$ & $\hat{G}_{S T}$ \\
\hline Ampla distribuição geográfica & 43 & 0,380 & 0,293 & 0,253 \\
Reprodução sexual & 108 & 0,280 & 0,194 & 0,284 \\
Cruzamento animal & 23 & 0,352 & 0,238 & 0,221 \\
Reprodução mista (polin. animal) & 26 & 0,284 & 0,181 & 0,304 \\
Dispersão de sementes pelo vento & 38 & 0,260 & 0,238 & 0,073 \\
Dispersão de sementes por animais & 12 & 0,344 & 0,210 & 0,330 \\
Estágio sucessional intermediário & 42 & 0,262 & 0,196 & 0,236 \\
Estágio sucessional final & 28 & 0,299 & 0,275 & 0,071 \\
\hline
\end{tabular}

$n e:$ Número de espécies estudadas.

Tabela 5. Distribuição da variabilidade genética total $\left(\hat{H}_{T}\right)$, dentro $\left(\hat{H}_{S}\right)$ e entre $\left(\hat{G}_{S T}\right)$ algumas populações naturais de espécies arbóreas tropicais alógamas.

\begin{tabular}{|c|c|c|c|c|c|}
\hline Espécie & $n p$ & $\hat{H}_{T}$ & $\hat{H}_{s}$ & $\hat{G}_{S T}$ & Autores \\
\hline Alseis blackiana & 3 & 0,423 & 0,412 & 0,043 & Loveless \& Hamrick (1987) \\
\hline Aspidosperma polyneuron & 2 & 0,235 & 0,238 & 0,060 & Maltez (1997) \\
\hline Bertholletia excelsa & 2 & 0,190 & 0,183 & 0,037 & Buckley et al. (1988) \\
\hline Carapa guianensis & 9 & 0,328 & 0,313 & 0,046 & Hall et al. (1994) \\
\hline Cariniana legalis & 2 & - & 0,146 & 0,052 & Harritt (1991) \\
\hline Cryptocarya moschata & 4 & 0,332 & 0,287 & 0,107 & Moraes (1997) \\
\hline Esenbeckia leiocarpa & 2 & $\ldots$ & 0,179 & 0,064 & Seoane (1998) \\
\hline Hevea brasiliensis & 2 & 0,336 & 0,335 & 0,001 & Paiva (1992) \\
\hline Hybanthus prunifolius & 3 & 0,351 & 0,335 & 0,041 & Loveless \& Hamrick (1987) \\
\hline Joannesia princeps ${ }^{\mathrm{a}}$ & 2 & $\ldots$ & 0,140 & 0,069 & Harritt (1991) \\
\hline Miracrodruon urundeuva & 2 & 0,495 & 0,436 & 0,036 & Moraes (1993) \\
\hline Psychotria horizontalis & 3 & 0,290 & 0,277 & 0,039 & Loveless \& Hamrick (1987) \\
\hline Quararibea asterolepis & 3 & 0,374 & 0,365 & 0,021 & Loveless \& Hamrick (1987) \\
\hline Rinorea sylvatica & 3 & 0,318 & 0,236 & 0,083 & Loveless \& Hamrick (1987) \\
\hline Sorocea afinis & 3 & 0,322 & 0,307 & 0,047 & Loveless \& Hamrick (1987) \\
\hline Swartzia simplex & 3 & 0,358 & 0,337 & 0,035 & Loveless \& Hamrick (1987) \\
\hline Média & & $\begin{array}{c}0,335 \\
{[ \pm 0,046]}\end{array}$ & $\begin{array}{c}0,283 \\
\pm 0,0481\end{array}$ & $\begin{array}{c}0,049 \\
\pm 0,0131\end{array}$ & \\
\hline
\end{tabular}


Espécies que apresentam ampla distribuição geográfica, gerações longas, polinização pelo vento, sistema de reprodução por cruzamentos, longo tempo de fecundidade e ocorrem em estágios finais de sucessão, tendem a manter maiores nivveis de variabilidade genética do que espécies com outras combinações destes fatores (Hamrick et al., 1979; Hamrick, 1983; Loveless \& Hamrick, 1984; Hamrick \& Godt, 1989). De acordo com a Tabela 4 e 5 , espécies de reprodução mista, polinizadas por animais ou vento, dispersão das sementes pelo vento e de estágio final de sucessão, tendem a apresentar menor variabilidade genética entre populações e alta dentro das populações.

Estudos da estrutura intrapopulacional de espécies arbóreas têm demonstrado que a distribuição de alelos e genótipos não é aleatória dentro das populações (Ledig, 1974; Sorensen, 1973; Coles \& Fowler, 1976; Dewey \& Heywood, 1988; Loveless \& Hamrick, 1984; Knowles et. al., 1992; Chung \& Epperson, 2000). Tal estrutura pode ser determinada pela dispersão de pólen e sementes, habitat de distribuição e seleção microambiental (Hamirck, 1983; Epperson, 1990). A relação temporal e espacial entre indivíduos próximos aumenta a probabilidade de intercruzamento e se os mecanismos de dispersão de pólen e sementes forem restritos a uma pequena vizinhança, aumentam as chances destes indivíduos serem aparentados (Coles \& Fowler, 1976). O cruzamento entre parentes gera endogamia, apesar de ser uma forma menos drástica do que a autofecundação efetiva, mas é a única forma de ocorrência de endogamia em espécies que apresentam sexos separados (Allard, 1971; Chung \& Epperson, 2000). Muito da endogamia observada dentro de populações naturais de espécies arbóreas é determinada pela distância e taxa com que os genes migram dentro e entre populações (Coles \& Fowler, 1976). A outra parte, é determinada por seu sistema de reprodução, mais especificamente, pela taxa de autofecundação. Se o movimento de genes é extenso, resultando em fluxo gênico a longa distância, espera-se baixa endogamia dentro das populações e baixa divergência genética entre populações. Se, contudo, o fluxo de genes efetivo é limitado e a troca gênica entre árvores vizinhas é comum, pode ocorrer uma alta proporção de endogamia dentro das populações e divergência entre populações (Coles \& Fowler, 1976). Entretanto, caso o movimento de genes via pólen seja longo e via sementes seja restrito, são esperados baixos níveis de endogamia dentro das populações, moderados 
níveis de divergência genética entre populações, mas altos níveis de parentesco dentro das populações (população estruturada em famílias).

Do ponto de vista da conservação genética, a perda de parte de uma população subdividida em estrutura de famílias pode ser tão crítica, no sentido genético, quanto a perda de uma população inteira (Hamrick, 1983), dado que a variabilidade genética dentro das populações é principalmente garantida pela variabilidade genética existente entre subpopulações. Seoane et al. (2000) encontrou parentesco dentro e variabilidade isoezimática entre sub-populações de Esenbeckia leiocarpa, uma espécie arbórea tropical de estágio final de sucessão, que ocorre em grupos de até 100 indivíduos, concluindo que a variabilidade genética entre as sub-populações era importante para a evolução e perpetuação da espécie.

\subsubsection{Variabilidade Isoezimática Versus Caracteres Quantitativos}

A técnica de eletroforese de isoezimas apresenta vantagens sobre os métodos clássicos de genética quantitativa na análise da estrutura genética de populações, como: a herança genética das características detectadas (bandas isoenzimáticas) poder ser facilmente demonstrada; a maioria dos locos são codominantes e as freqüências gênicas podem ser calculadas diretamente sem a necessidade de cruzamentos genéticos; as estimativas da variabilidade genética podem ser comparadas diretamente entre populações ou espécies e; um conjunto de locos pode ser acessado usando-se pequena quantidade de material (Hamrick et al., 1979; Hamrick, 1989). Além disso, Cheliak \& Pitel (1984) acrescentam que os marcadores genéticos não são associados aos caracteres fenotípicos, sendo, portanto, neutros, ou agem como variantes casuais não influenciados diretamente pela seleção natural, permitindo a formulação de hipóteses relativas à quantidade, distribuição e manutenção da variabilidade genética. Outras vantagens seriam: permitir a caracterização da estrutura genética das populações em curto espaço de tempo (alguns meses), não exigir área experimental, menos limitação no número de populações a serem estudadas e o fato dos custos equivalerem aos métodos clássicos de experimentação de campo, além de as enzimas serem a expressão direta dos genes, o que aumenta a precisão das estimativas dos parâmetros genéticos (Stebbins, 1989). Brown (1989), por sua vez, 
acrescenta a vantagem de poder-se estudar o sistema de cruzamento da espécies e que vários locos enzimáticos são polimórficos em muitas populações. Contudo, a maior desvantagem é que o significado adaptativo das isoenzimas permanece obscuro.

Apesar disso, existem poucos estudos que examinam a relação entre isoenzimas e variação poligênica (Hamrick, 1983). Moraes (1993) estudou a estrutura genética de duas populações de Myracrodruon urundeuva por isoenzimas e caracteres quantitativos, observando alta congruência nos resultados, sendo que em ambos os casos a maior parte da variabilidade genética encontrava-se dentro das populações.

Estudos com isoenzimas têm mostrado que, em média, espécies arbóreas de cruzamento, apresentam 5\% da variabilidade genética distribuídas entre populações (ver Tabela 5). Por sua vez, os caracteres quantitativos mostram maior diferenciação genética entre populações do que isoenzimas (Hamrick, 1983). Estudos com espécies florestais, emvolvendo caracteres quantitativos têm em média $14,3 \%[ \pm 3,8 \%]$ de divergência genética entre populações (Tabela 6). Também observa-se uma grande variação nos resultados de caráter para caráter (Hamrick, 1983; Moreas, 1993; Sebbenn et al., 1999a). Isto indica que alguns caracteres morfológicos apresentam alta variação genética entre populações, onde outros não. Existem algumas evidências de que caracteres com grandes diferenças entre populações, são os responsáveis pela adaptação das espécies às condições ambientais locais (Hamrick, 1983).

Análises da estrutura de populações de espécies arbóreas, simultaneamente por caracteres quantitativos e isoenzimas, têm revelado resultados coerentes e similares (Boyle \& Yeh, 1988; Moraes, 1993; Yang et al., 1995), como já comentado. Segundo Hamrick (1983), existem algumas associaçōes entre a distribuição de isoenzimas e caracteres quantitativos e os fatores que influenciam a distribuição da variabilidade isoenzimática, também influenciam a distribuição da variação quantitativa. Por sua vez, Brown (1978) afirma que é possível que estes diferentes tipos de medidas da variabilidade genética amostram diferentes locos, o que pode ser a causa de algumas diferenças observadas entre isoenzimas e caracteres quantitativos. 
Tabela 6. Número de caracteres $(n c)$, populações $(n p)$ e relação entre a variância genética entre populações $\left(\hat{\sigma}_{P}^{2}\right)$ e variância fenotípica total $\left(\hat{\sigma}_{d p}^{2}\right)$, para algumas espécies arbóreas.

\begin{tabular}{|c|c|c|c|c|}
\hline Espécie & $n c$ & $n p$ & $\hat{\sigma}_{p}^{2}$ & Autor \\
\hline Abies concolor & 13 & 4 & 0,203 & Hamrick (1976) \\
\hline Abies concolor ${ }^{b}$ & 13 & 4 & 0,346 & Hamrick \& Libby (1972) \\
\hline Acer platanoides & 3 & 7 & 0,111 & Buliuckas et al. (1999) \\
\hline Alnus glutinosa & 2 & 3 & 0,055 & Buliuckas et al. (1999) \\
\hline Balfourodendron riedelianum & 2 & 3 & 0,026 & Siqueira et al. $(2000 \mathrm{a})$ \\
\hline Fagus sylvatica & 1 & 3 & 0,054 & Buliuckas et al. (1999) \\
\hline Fraxinus excelsior & 3 & 4 & 0,113 & Buliuckas et al. (1999) \\
\hline Grevillea robusta & 2 & 7 & 0,046 & Sebbenn et al. (1999a) \\
\hline Myracrodruon urundeuva & 14 & 2 & $-0,049$ & Morges (1993) \\
\hline Peltophonum dubium & 2 & 2 & 0,012 & Sebbenn (nâo publicado) \\
\hline Picea glauca & 14 & 4 & 0,111 & Liet al.(1993) \\
\hline Picea mariana & 11 & 9 & 0,610 & Khalil (1985) \\
\hline Picea sitchensis & 2 & 14 & 0,535 & Kehlet \& Roulund (1998) \\
\hline Pinus contorta spp. latifolia & 6 & 5 & 0,120 & Yang at al. (1995) \\
\hline Pinus ponderosa & 11 & 11 & 0,105 & Rehfeldt (1999) \\
\hline Pinus taeda & 4 & 9 & 0,041 & Owino (1977) \\
\hline Pinus caribaea var. hondurensis & 3 & 14 & 0,150 & Zheng et al (1994) \\
\hline Pinus oocarpa & 3 & 21 & 0,130 & Ettoriet al. (2001) \\
\hline Pseudotsuga menziesii & 6 & 26 & 0,097 & Christophe \& Birot (1979) \\
\hline Pterogyne nitens & 2 & 4 & 0,048 & Sebbenn et al. $(2000 \mathrm{~b})$ \\
\hline Média & \multicolumn{4}{|c|}{$0,143[ \pm 0,038]$} \\
\hline
\end{tabular}

De modo geral, estes resultados mostram que, para a conservação de uma espécie arbórea, deve-se utilizar métodos de amostragem que incluam todos os níveis de variabilidade presente na espécie, indo desde a amostragem de individuos dentro de subpopulações à variação existente entre diferentes regiōes geográficas e altitudinais de distribuição de uma espécie. Também é possível verificar que, no caso da conservação in situ, a análise por marcadores genéticos é vantajosa, pelo menor tempo e custo de avaliação. Contudo, quando se pensa na conservação ex situ, os ensaios de campo passam a ter maior valor, dado que permitem a avaliação da capacidade adaptativa das espécies. Para o desenvolvimento de estratégias adequadas para a conservação genética é necessário combinar estudos de marcadores genéticos, caracteres morfológicos e fisiológicos que 
descrevam a variação genética entre e dentro de populações naturais de plantas (Hamrick, 1983).

Finalmente, a análise da estrutura genética de populações fornece importantes subsídios para o entendimento da dinâmica evolutiva das espécies (Hamrick, 1983; Hamrick, 1989). Estes estudos têm sido conduzidos principalmente em populações naturais de plantas e animais, visando um maior entendimento de sua dinâmica evolutiva para fins de conservação e melhoramento genético (Hamrick, 1989). Entretanto, mais recentemente, sua aplicação têm se estendido a trabalhos de manejo de populações naturais de essências florestais e fragmentação florestal, visando determinar os impactos da intervenção antrópica na variabilidade genética das espécies (Sebbenn, et al. 2000a; Seoane et al., 2000).

\subsubsection{Quantificando a Estrutura Genética de Populações}

A estrutura de populações pode ser avaliada tanto por caracteres quantitativos como por isoenzimas, como previamente discutido. Para caracteres quantitativos, o teste $\mathrm{F}$ da análise de variância permite verificar a existência de diferenças entre populações e entre progênies dentro de populações, entretanto, não informa sobre a magnitude desta variação. Assim, tem-se adotado análises que permitam quantificar a magnitude da variabilidade genética, entre e dentro de populações a partir da contribuição isolada dos componentes de variância para a variância total. Esta abordagem foi inicialmente adotada em espécies arbóreas, por Hamrick (1976). O autor estudando populações de Abies concolor (Dougla-Fir), partiu a variabilidade genética total $\left(\sigma_{T}^{2}=\sigma_{d}^{2}+\sigma_{F / F}^{2}+\sigma_{P}^{2}\right)$ nos seus componentes entre $\left(\sigma_{P}^{2}\right)$ e dentro $\left(\sigma_{d}^{2}+\sigma_{F / P}^{2}\right)$ de populações. Recentemente, contudo, Yang et al. (1995) propuseram uma análise alternativa a este método, denominada de "estatística $F$ para caracteres quantitativos". Esta estatística baseia-se na pressuposição de que as populações encontram-se em Equilíbrio de Hardy-Weinberg, podendo-se assim estimar a relação:

$$
F_{\mathrm{ST}}=\frac{\sigma_{P}^{2}}{\sigma_{p}^{2}+\sigma_{d}^{2}}
$$


onde: $F_{S T}=$ divergência genética entre populações; $\sigma_{P}^{2}=$ variância genética entre populações e; $\sigma_{d}^{2}$ variância fenotípica dentro de populações.

Por outro lado, o estudo da estrutura genética de populações, a partir de dados de marcadores genéticos, pode ser realizado por três metodologias básicas: diversidade genética de populações subdivididas (Nei, 1973), estatísticas F (Wright, 1951; Nei 1977) e análise de variância de freqüências gênicas (Cockerham, 1969). A diversidade genética de Nei fornece, a partir de uma metodologia estatística simples, a proporção da variabilidade genética contida entre e dentro das populações e os níveis de heterozigosidade esperados para o total e média das populações (Nei, 1973). As estatísticas $F$ fornecem os índices de fixação de alelos para o total das populações, média dentro e entre populações, com base em medidas de probabilidade de identidade por descendência (Wright, 1951; Nei 1977). A análise da variância fornece a distribuição da variabilidade genética em diversos níveis hierárquicos, considerando o processo amostral nas estimativas. A diversidade genética de populações subdivididas foi desenvolvida por Nei (1973), com o intuito de obter uma medida de estrutura de populações que acomodasse locos multialélicos, assim, foi considerada uma versão multialélica das estatísticas $F$ (Nei, 1973; 1977; Berg \& Hamrick, 1997). Com essa idéia, Nei decompôs a heterozigosidade esperada média total das populações $\left(H_{T}\right)$, nos seus componentes entre $\left(D_{S T}\right)$ e dentro de populações $\left(H_{S}\right)$, obtendo uma medida que poderia ser utilizada em qualquer população, independente do número de alelos por loco, sistema reprołução e da atuação de forças evolutivas (seleção, deriva genética, mutação e migração). Os parâmetros da análise de populações subdivididas de Nei (1973) são relacionados por:

$$
H_{T}=H_{S}+D_{S T} \text {. }
$$

As estatísticas $F$ foram inicialmente desenvolvidas para o caso de um loco com dois alelos (Wright, 1951). Posteriormente, Nei (1977) estendeu esta metodologia para locos multialélicos, contrastando um alelo $p$ contra os outros alelos $(1-p)$ através dos conceitos de heterozigosidade observada e esperada. Esta estatística admite que todos os desvios de panmixia sejam exclusivamente devidos aos efeitos da deriva genética e do sistema de reprodução. Considerando uma espécie subdividida em várias populações, as 
estatísticas $\mathrm{F}$ fornecem os níveis médios de fixação de alelos dentro das populą̧ões $\left(F_{I S}\right)$, a divergência genética entre populações $\left(F_{S T}\right)$ e os níveis de fixação de alelos para o total das populações ( $F_{I T}$ ), parâmetros relacionados entre si pela expressão:

$$
\left(1-F_{I T}\right)=\left(1-F_{I S}\right)\left(1-F_{S T}\right)
$$

A análise de frequêencias gênicas (Cockerham, 1969) foi desenvolvida baseada na pressuposição de que as populações em estudo são oriundas de uma mesma população ancestral, permitindo assim a estimativa de coeficientes de parentesco (coancestralidade) e endogamia. Nesta metodologia, todos os desvios de panmixia (cruzamentos aleatórios), também são tomados por serem exclusivamente devidos a deriva genética e ao sistema de reprodução. Igualmente às estatísticas $F$, a análise de freqüências gênicas fornece os niveis de fixação de alelo médios dentro das populações $(f)$ e totais das populações $(F)$ e a divergência genética entre populações ou o coeficiente de parentesco entre dois individuos dentro de populações $\left(\theta_{p}\right)$, parâmetro relacionados por:

$$
f=\frac{\left(F-\theta_{p}\right)}{\left(1-\theta_{p}\right)}
$$

Comparando-se estas metodologias, têm-se as seguintes considerações: (i) As estatísticas $F$ de Wright (1951) e a diversidade de populações subdivididas de Nei (1973), não consideram, nas estimativas dos parâmetros, o aspecto do erro associado a amostragem, logo, a estimativa é assumida como o próprio parâmetro populacional. Por sua vez, a análise de frequiências gênicas de Cockerham (1969) considera o fato dos dados serem uma amostra de uma população e não a população em si, sendo as estatísticas obtidas, estimativas de um parâmetro populacional verdadeiro, portanto, estão associadas a um erro amostral. (ii) Devido ao fato do modelo de Wright (1951) e de Nei (1973) não considerarem o erro associado à amostragem, elas tendem a ser viciadas, sendo este tanto maior quanto menor for o tamanho amostral. (iii) Se os marcadores forem neutros, a amostragem aleatória e as populações forem originadas de uma única população ancestral, pode-se optar igualmente por qualquer uma das três metodologias discutidas. A escolha será determinada pelo grau de detalhamento genético requerido pelo estudo. Caso os dados não se ajustem à pressuposição do modelo de Cockerham, de as populações terem 
uma origem comum, mas a amostragem das populações tenha ocorrido de forma aleatória, o pesquisador pode optar por usar tanto o método proposto por Wright (1951) como por Nei (1973). Na presença de modelos fixos, por exemplo, amostras de acessos de germoplasma, uma op̧̧ão é usar o modelo de Nei (1973) ou o de Wright (1951), porém, interpretando a estatística $F_{I S}$ e $F_{I T}$ apenas como uma medida de fixação de alelos do material em estudo e a estatística $F_{S T}$, como de divergência genética entre acessos. Contudo, a melhor opção é usar o modelo fixo de análise de variância de freqüências gênicas apresentado por Weir (1996) que separa a variação genética entre e dentro das subdivisões, não estimando parâmetros de parentesco e endogamia. Vale ressaltar que $G_{S T} \cong F_{s T} \cong \theta_{p}, F_{I S} \cong f$ e $F_{r T} \cong F$, sendo que a primeira similaridade, nos casos em que as populações em estudo têm origem comum, refere-se a coeficientes de parentesco e as duas últimas a índices de fixação, logo, a primeira é medida entre pares de indivíduos e as últimas dentro de indivíduos. Moraes (1993), Reis (1996) e Moraes (1998) utilizaram simultaneamente as três metodologias para a análise de populações de espécies arbóreas tropicais nativas brasileiras, sendo que todos observaram maior precisão estatística na análise de variância, justamente por considerar o processo amostral nas estimativas dos parâmetro genéticos.

\subsection{Depressão Por Endogamia em Essências Florestais}

A endogamia é o aumento da homozigosidade em individuos originados de autofecundação, cruzamento entre aparentados ou mais raramente pela seleção para homozigotos. Em populações naturais, a endogamia pode ser gerada pelo comportamento dos polinizadores, visitando principalmente flores de uma mesma árvore (autofecundação), devido à estruturação interna das populações, em grupos de indivíduos aparentados, localizados espacialmente próximos, ou pela redução do tamanho das populações. Em populações de melhoramento, a endogamia pode ser forçada pelos melhoristas através da autofecundação ou cruzamento entre aparentados. 
A mais notável consequência da endogamia é a redução do valor fenotípico médio, mostrado pelos caracteres relacionados com a capacidade reprodutiva ou eficiência fisiológica (Allard, 1971; Ritland, 1996; Falconer \& Mackay, 1997), fenômeno conhecido por depressão por endogamia (Mather, 1994). Quando ocorrem cruzamentos entre aparentados e autofecundação, as progênies tendem a ser menos vigorosas e férteis do que progênies de cruzamentos (Allard, 1971). Populações de cruzamento, historicamente grandes, que repentinamente declinam para uns poucos individuos, também usualmente reduzem a variabilidade e a fecundidade (Falconer \& Mackay, 1997). Esta depressão por endogamia é totalmente removida quando indivíduos endogâmicos são cruzados e em algumas circunstâncias o desempenho é aumentado pelo vigor de híbrido (Matheson et al., 1995). Este fenômeno, ou o aumento no valor fenotípico médio dos heterozigotos, é conhecido como heterose (Mitton, 1989).

As primeiras evidências de depressão por endogamia em plantas foram apontadas por Charles Darwin em 1876, comparando a capacidade adaptativa de progênies de cruzamento e autofecundação (Schemske \& Lande, 1985; Charlesworth \& Charlesworth, 1987; Ritland, 1994; Husband \& Schemske, 1996; Kärkkäinen et al., 1996). O aumento rápido da endogamia em pequenas populações produz aumento da homozigosidade de mutantes recessivos deletérios, que por sua vez, são mantidos como raros em heterozigose pela seleção natural em grandes populações, e pela probabilidade de que tais mutantes venham a se fixar em pequenas populações por deriva genética (Allard, 1971; Falconer \& Mackay, 1997). Isto significa que se uma população de cruzamentos aleatórios que abrigue alelos recessivos deletérios tornar-se endogâmica, haverá, de início, uma considerável depressão por endogamia, à medida que os alelos são expostos em homozigose. Eventualmente, entretanto, a população poderá reconquistar alta média de valor adaptativo à medida que a seleção natural expurgar da população os alelos deletérios. Tal população terá menos variação genética do que outra praticando cruzamentos aleatórios, o que não ocorre devido à autofecundação em si, mas pela ação combinada da autofecundação e da seleção natural (Futuyma, 1992).

Contudo, a endogamia advinda da redução no tamanho das populações cria relativamente pouca depressão por endogamia permanente, dado que a seleção natural tende a expurgar das populações alelos recessivos deletérios quando eles combinam-se em 
homozigose (Falconer \& Mackay, 1997), reduzindo a depressão por endogamia na ausência de mutação (Crow, 1993). A taxa com que a seleção natural remove os genes recessivos deletérios é a chave da dinâmica da depressão por endogamia. Esta remoção é oposta à entrada de novos genes via mutação e, é rápida para genes de efeito maior (por exemplo, genes letais), levando a expectativa de que a depressão por endogamia possa ocorrer devido aos muitos genes de pequeno efeito. Entretanto, a eliminação é ineficiente para genes de efeito sobredominante (Ritland, 1996).

A depressão por endogamia é a maior força seletiva favorecendo o cruzamento no florescimento de plantas. Contudo, algumas autofecundações podem atenuar os efeitos prejudiciais da endogamia pela exposição de alelos deletérios para a seleção (Koelewijin et al., 1999). Se a endogamia reduz o valor adaptativo, a seleção natural provavelmente irá se opor ao processo de endogamia, por favorecer os individuos menos homozigotos (Falconer \& Mackay, 1997).

O grau com que a depressão por endogamia estará envolvida depende da magnitude da endogamia, de sua base genética, do número de locos que contribuem para o fenômeno e da magnitude dos efeitos dos alelos destes locos (Lande et al., 1994). Muitos estudos têm mostrado que a depressão por endogamia pode ser gerada por alelos de efeito recessivo ou sobredominante (Charlesworth \& Charlesworth, 1987). Existem na realidade, duas principais hipóteses para explicar a base genética da depressão por endogamia, a hipótese de sobredominância e a hipótese de dominância parcial ou balanço mutaçãoseleção. Ambas dependem do fato que a autofecundação aumenta a homozigose na progênie, em relação a uma progênie de cruzamentos. Assim, de acordo com a hipótese de sobredominância, progênies de cruzamento apresentam melhor desempenho por elas terem uma grande proporção de locos para adaptação em heterozigose e muito destes locos são sobredominantes, ou seja, a methor performance ocorre devido à vantagem dos heterozigotos em locos adaptativos. Já, de acordo com a hipótese de dominância parcial ou balanço mutação-seleção, a causa da menor adaptação de progênies derivadas de autofecundação em relação às de cruzamentos é a exposição de genes recessivos letais e mutações deletérias nas progênies endogâmicas (Mitton, 1989; Kärkkäinen et al., 1996; Koelewijn, 1998; Koelewijn et al., 1999). Estas duas hipóteses têm sido testadas em 
vários caracteres e espécies de plantas, a fim de determinar qual é a verdadeira causa da depressão por endogamia ou quando uma é mais importante do que a outra. Todavia, segundo Mitton (1989), nenhuma destas duas hipóteses têm sido rejeitadas e parece provável que ambas contribuam para o fenômeno. Entretanto, Crow (1993) afirma que a vasta maioria dos estudos têm mostrado que os alelos recessivos deletérios são mais importantes que os alelos sobredominates na causa da depressão por endogamia, sendo portanto a segunda hipótese a mais plausível. Ainda, segundo Crow, os alelos letais parecem ser a causa da redução da produtividade pelo aborto de sementes e mortalidade das plantas e os alelos deletérios pelas alterações negativas do fenótipo dos indivíduos como perda de forma, fertilidade e menor produção de sementes.

Como visto, a depressão por endogamia pode ser atribuída à dominância, sobredominância, epistasia e aos genes deletérios. Para existir depressão por endogamia é fundamental a presença de dominância. Autofecundando-se um heterozigoto de um loco particular são produzidos dois tipos de homozigotos $(A A$ e $a a)$ e um heterozigoto $(A a)$ na progênie. Na ausência de dominância isto não afetaria a média da população, dado que ambos homozigotos são produzidos com a mesma freqüência, na média. Porém, quando existe dominância, autofecundando-se um heterozigoto (que tem média igual ao homozigoto dominante), são produzidos homozigotos recessivos que são diferentes dos homozigotos dominantes e dos heterozigotos. Se o loco afeta um caráter quantitativo e o alelo recessivo tem menor efeito do que o dominante, a autofecundação reduzirá a média da população. Considerando muitos locos que afetam um caráter, quando ocorre depressão por endogamia, a dominância predomina em uma direção, ou seja, dominância direcional (Falconer \& Mackay, 1997; Williams \& Savolainen, 1993).

Com sobredominância em um loco, a frequiência do heterozigoto (que tem média maior que o homozigoto dominante) é reduzida sobre endogamia, reduzindo a média da população. Contudo, a sobredominância não é condição essencial para existir depressão por endogamia (Matheson et al., 1995).

A epistasia também pode atuar para produzir depressão por endogamia, porém apenas na presença de dominância direcional. A presença de epistasia na depressão por endogamia é indicada quando a relação entre a depressão por endogamia e o coeficiente de endogamia não é linear (Crow \& Kimura, 1970; Falconer \& Mackay, 1997). Se os 
locos se combinam aditivamente, a mudança da média de uma população com a endogamia é diretamente proporcional ao coeficiente de endogamia $(f)$, e a mudança da média é linear quando traçada em função de $f$. Se existe interação epistática entre locos, a relação entre a média e o coeficiente de endogamia não é linear, devido aos desvios de interação de duplo ou múltiplos locos heterozigotos (Crow \& Kimura, 1970; Falconer \& Mackay, 1997). Contudo, mesmo se a relação é linear, quando existem efeitos epistáticos negativos e positivos, um pode cancelar o outro, mascarando a epistasia. Entretanto, devido a, geralmente, não existir significantes desvios do modelo linear, os efeitos da epistasia sobre a depressão por endogamia não parecem ser importantes (Crow \& Kimura, 1970; Hallauer \& Miranda Filho, 1988).

Ritland (1994), discutindo o tipo de resposta da ação gênica da depressão por endogamia frente ao aumento da endogamia $(f)$, ressalta um outro ponto importante que, na fase inicial de experimentação, pode ocorrer a extinção de indivíduos que possuem alelos que em combinação são deletérios, mascarando o sinergismo negativo (interação negativa entre locos adaptativos). Assim, a regressão de adaptação sobre o coeficiente $f$ pode tornar-se linear quando as linhagens ou indivíduos extintos são ignorados porém curvilineares quando são incluídos.

Quando alelos deletérios são recessivos, a seleção ocorre contra estes, quando em estado homozigoto, assim, sua frequência populacional será baixa. Muitos de tais alelos podem ocorrer em heterozigose, mas também em baixa freqüência. Os homozigotos recessivos serão muito raros nas populações, sendo que progênies com tais genes em homozigose terão média muito menor que a média da população. Se os alelos deletérios meramente reduzem o crescimento e não existe forte seleção contra estes, é possível que sua freqüência seja alta. Neste caso, a freqüência de homozigotos recessivos também pode ser alta, produzindo uma baixa média populacional, próxima à média de uma progênie endogâmica. A similaridade destas duas médias pode mascarar os efeitos reais da depressão por endogamia (Matheson et al., 1995).

A depressão por endogamia pode atuar em diferentes estágios de vida de um organismo, variar entre diferentes progênies, populações e caracteres. No primeiro caso, os genes deletérios responsáveis pela depressão em diferentes estágios de vida, não 
precisam ser obrigatoriamente os mesmos. Já, a variação entre plantas maternas e populações na depressão por endogamia pode ser esperada, devido às plantas diferirem no número de alelos deletérios que carregam, que em outros termos, poderia ser influenciado pelo seu histórico de endogamia. Outra hipótese poderia ser o acúmulo diferencial de mutações entre progênies e populações (Koelewijn et al., 1999).

Quando são comparadas progênies de autofecundação com as de cruzamentos, muitos estudos em coníferas e folhosas têm exibido depressão por endogamia para produção de sementes, floração, germinação, sobrevivência, crescimento, entre progênies e populações e aumentos na variação fenotípica dentro de progênies. Estudos têm mostrado que a depressão por endogamia pode reduzir o peso da semente e aumentar a mortalidade em plantios (Sorensen \& Miles, 1974). Sorensen \& Miles (1974) observaram depressão para crescimento em Pseudotsuga menziensii e Pinus ponderosa na ordem de 18 e $21 \%$, respectivamente, no primeiro ano de experimentação e mortalidades de 11 e 9\%. Libby et al. (1981), verificaram que o crescimento em altura das progênies de autofecundação de Sequoia sepervirens, após 1 ano de plantio em viveiro e no campo, eram de 35 e $20 \%$, respectivamente, inferior ao crescimento das progênies de cruzamento entre aparentados. Após 4 anos de ensaio, os resultados tornaram-se mais contrastantes; as progênies de autofecundação apresentavam $42 \%$ da altura e $29 \%$ do DAP das progênies de cruzamentos entre aparentados. Sorensen \& Miles (1982) observaram que a depressão por endogamia em Pseudotsuga menziensii, Pinus ponderosa e Abies procera, para sobrevivência nos dois primeiros anos de plantio, variou de 3 a $16 \%$ e na idade de 10 anos de 0,4 a $3 \%$. Já para a altura de plantas os autores verificaram uma variação de 24 a $30 \%$ nos dois primeiros anos e entre 29 a $36 \%$ na idade de 10 anos. Wilcox (1983) verificou depressão por endogamia de menos de $1 \%$ por cada aumento de $10 \%$ na endogamia para forma do fuste e 3,97\% para compressão da madeira, em Pimes radiata. Geberek (1986) observou em Picea omorika que a altura e o DAP aos 15 anos de idade eram 27,3 e $53,6 \%$ superiores em progênies de cruzamento em relação às de autofecundação. Entretanto, aos 24 anos de idade, a superioridade do DAP de progênies de cruzamentos chegava a 50,5\%, comparativamente às de autofecundação. Griffin \& Cotterill (1988) estudando Eucalyptus regnans, notaram que, aos 45 meses, a altura, o DAP e o volume 
das progênies de cruzamentos eram em média 11,18 e $37 \%$, respectivamente, superiores aos das progênies de autofecundação. Eles também observaram diferenças na depressão por endogamia em relação às árvores maternas, com valores variando entre $25,1 \%$ a $62,8 \%$ para volume, sugerindo que alguns individuos podem gerar mais depressão por endogamia do que outros, devido possivelmente a sua maior carga genética. Sniezko \& Zobel (1988) estudando Pinus taeda, em condições de viveiro, encontraram baixas evidências de depressão por endogamia. Os autores atribuíram este resultado às ótimas condições de experimentação. Durel et al. (1990) quantificaram a depressão por endogamia em Pinus pinaster, aos 10 anos de idade, na ordem 27, 37, 63, 23 e 89\% para altura, circunferência à altura do peito $(1,3 \mathrm{~m})$, volume cilíndrico, área basal e fertilidade materna (número de cones), respectivamente. Kärkkäinen \& Savolainen (1993) estudando como a depressão por endogamia inicial poderia determinar a taxa de autofecundação em Pinus sylvestris, verificaram que genótipos que tinham menor número de embriões letais, apresentavam taxas mais altas de autofecundação e que a depressão por endogamia inicial mantém baixa a taxa de autofecundação no estágio de sementes, mascarando a correlação entre a taxa de autofertilização e a taxa de autofecundação no estágio de sementes. Hardner \& Potts (1995) notaram em Eucalyptus globulus ssp. globulus menor crescimento para progênies de autofecundação em relação às progênies de cruzamento $\mathrm{e}$ polinização aberta. Matheson et al. (1995) observaram que progênies de Pinus elliottii var. elliottii de autofecundação tinham menor média em DAP e volume do que de cruzamento. Kärkkäinen et al. (1996) pesquisando a variação geográfica da depressão por endogamia em Pinus sylvestris encontraram variação entre regióes na taxa média de aborto de sementes e no número de embriões letais em progênies de autofecundação, sugerindo que diferentes populações possam apresentar diferentes cargas genéticas. Hardner \& Potts (1997) também observaram variação na depressão entre diferentes populações de Eucalyptus regnan, para sobrevivência aos 15 anos de idade, sendo esta, em média, 67\% maior nas progênies de autofecundação. Sorensen (1997) estudando

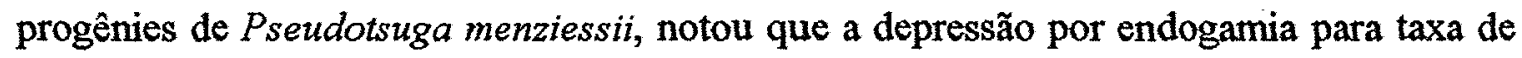
crescimento em altura e DAP era de 6 e $8 \%$, respectivamente, para um aumento de $10 \%$ no coeficiente de endogamia $(f)$. Wu et al. (1998) verificaram que a depressão por 
endogamia em Pinus radiata, aos 12 anos de idade, reduziu o DAP, a altura e a sobrevivência. Neste caso, a depressão por endogamia chegou a 19\% para DAP e $11 \%$ para sobrevivência em duas gerações de autofecundação. Koelewijn et al. (1999) observaram em Pinus sylvestris, alta depressão por endogamia para maturação de sementes $(\hat{\delta}=0,74)$ e para sobrevivência pós-germinação (variação entre 0,62 a 0,75 ), mas não foram observadas depressões por endogamia significativas para altura de plantas $(\hat{\delta}=0,05)$ e florescimento $(\hat{\delta}=0,014)$, aos 23 anos de idade. Entre progênies, a depressão por endogamia foi alta $(\hat{\delta}=0,90-0,94)$ e significativamente diferente entre plantas maternas (variando de 0,45 a 1,00 ).

$\mathrm{Na}$ literatura também existem estudos que relatam que a depressão endogamia está linearmente correlacionada com o coeficiente de endogamia (Sniezko \& Zobel, 1988; Durel et al., 1990; Matheson et al., 1995; Sorensen, 1997; Wu et al., 1998). Outro aspecto interessante, foi observado por Libby et al. (1981) e Sniezko \& Zobel (1988). Estes autores verificaram que sob boas condições de viveiro, as progênies de autofecundação não apresentavam depressão por endogamia, mas sob condições de estresse a taxa sobrevivência era menor em progênies de autofecundação, relativamente às de cruzamento. Em muitos estudos também foi observado que a variância fenotípica dentro de progênies de autofecundação era maior do que nas de cruzamento (Sniezko \& Zobel, 1988; Geberek, 1986; Hardner \& Potts, 1995; Matheson et al., 1995; Wu et al., 1998).

Um outro ponto importante a ser considerado é que a variação na depressão por endogamia entre progênies de polinização aberta pode levar a erros nas estimativas dos coeficientes de herdabilidade no sentido restrito, correlações genéticas e ganhos preditos na seleção. Esta variação na endogamia é confundida com os efeitos de progênies per se e pode substancialmente inflar a estimativa da variância genética aditiva (e eventualmente a covariância). Por isso, deve-se ter cautela no uso de estimativas de parâmetros genéticos de progênies de polinização aberta como base para a construção de índices de seleção para a estimativa de ganhos (Griffin \& Cotterill, 1988).

E finalmente, a utilização de métodos que identificam locos especificos que causam a depressão por endogamia, como estudos de locos de caracteres quantitativos 
(QTLs), podem ser de grande valor na resolução da arquitetura genética da depressão por endogamia, que inclui todas as facetas deste tipo de ação gênica, como: tipo de ação (dominância vs. sobredominância), número de genes envolvidos (poucos vs muitos), estado de ação (letais, sub-letais ou semiletais) e interação e ligação gênica. Tais estudos podem ser feitos utilizando-se marcadores genéticos (Ritland, 1996).

\subsection{Estimativas de Parâmetros Genéticos EM Progênies de POLINIZAÇÃo ABERTA}

A utilização de progênies de polinização aberta tem sido muito difundida em programas de melhoramento florestal, devido à facilidade, baixo custo e rapidez de obtenção. Em tais situações, muitos geneticistas florestais têm estimado a variância genética aditiva $\left(\sigma_{A}^{2}\right)$ e os coeficientes de herdabilidade assumindo que o coeficiente de parentesco $\left(r_{x y}=2 \theta_{X Y}\right)$ entre progênies é de 1/4. Progênies de polinização aberta terão esta relação de parentesco apenas quando os genitores não forem aparentados, endogâmicos, não ocorrer autofecundação e todos os indivíduos de uma mesma progênie tiverem sido gerados por pólen de diferentes pais. Considerando que estas pressuposições são difíceis de ocorrer na natureza, acredita-se que a correlação média entre indivíduos dentro de progênies é maior do que 1/4 (Namkoong, 1966; Squillace, 1974). Violações nas pressuposições levam a erros nas estimativas da $\sigma_{A}^{2}$, que por sua vez, levam a erros nas subseqüentes estimativas de herdabilidades e ganhos na seleção (Namkoong, 1966; Fujishima \& Fredeen, 1972; Squillace, 1974; Surles et al., 1990).

No caso de experimentos instalados em apenas um ambiente, onde os efeitos da interação genótipo ambiente não são de interesse primário, sendo os efeitos de progênies a principal causa de variação a ser conhecida, para fins de seleção, tem-se a seguinte situação: A variação atribuída a diferenças entre os efeitos médios (aditivos) das progênies pode também ser expressa pela covariância entre indivíduos dentro de progênies e os componentes de variância entre progênies $\left(\sigma_{f}^{2}\right)$ podem ser interpretados como uma função de tais covariâncias. A seleção aleatória e o plantio de indivíduos dentro de progênies, na média, resultará na covariância entre pares aleatórios de indivíduos tomados 
dentro de progênies, o que será a covariância genética. Contudo, a covariância dependerá da proximidade de ancestria dos individuos dentro das progênies, que é sua co-ancestria. A partir disso, nota-se que em progênies de polinização aberta, a $\sigma_{f}^{2}$ também estima a covariância dos efeitos aditivos entre meios irmãos tomados aleatoriamente dentro das progênies. Assumindo ausência de epistasia e ligação, esta covariância de meios irmãos pode ser interpretada em termos de efeitos gênicos aditivos, isto é, $1 / 4$ de $\sigma_{A}^{2}$, como já apresentado.

Tais pressuposições podem ser entendidas a partir das derivações dessa variância por Comstok \& Robinson (1948) e Kempthorne (1957), além das considerações de Squillace (1974). Comstock \& Robinson (1948) derivaram a estimativa da $\sigma_{A}^{2}$ para o caso de locos com apenas dois alelos como:

$$
\sigma_{A}^{2}=2 p(1-p) \mu^{2}[1+\mathbf{a}(1-2 p)]^{2}
$$

Onde o termo $[1+\mathrm{a}(1-2 p)]^{2}$, corresponde ao efeito médio de substituição gênica ao quadrado, $p=$ corresponde à freqüência do alelo favorável, $\mu=$ a diferença entre o valor dos homozigotos opostos, $(A A$ e $a a)$, e $a=$ ao desvio do heterozigoto da média dos dois homozigotos. Kempthome (1957) e Falconer \& Mackay (1997) explicam detalhadamente o conceito de "efeito médio de substituição gênica".

Por sua vez, Kempthorne (1957) derivou a $\sigma_{A}^{2}$, sem restrição quanto ao número de alelos envolvidos no loco, a partir dos efeitos de um modelo linear, como:

$$
\sigma_{A}^{2}=2 \sum_{k=1}^{m} p_{k} \alpha_{k}^{2},
$$

onde o somatório inclui todos os $m$ alelos de um loco $k, p_{k}=$ frequência do $k$-ésimo alelo, e $\alpha_{k}=$ efeito aditivo médio do $k$-ésimo alelo.

Para estas derivações, Kempthorne assumiu as seguintes pressuposições: i) herança normal, diplóide e mendeliana; ii) ausência de correlações ambientais entre parentes; iii) equilíbrio de ligação, podendo assim, a variância ser somada sobre todos os locos efetivos para obter a $\sigma_{A}^{2}$ do caráter; iv) que os genitores não são endogâmicos e, v) que os cruzamentos ocorram aleatoriamente dentro de uma população específica e que os 
genitores podem ser considerados membros aleatórios de uma mesma população, sem parentesco.

De acordo com Cockerham (1961), muitas espécies ajustam-se à pressuposição i. A utilização de delineamentos experimentais com a requerida aleatorização (repetições, tratamentos, indivíduos), usualmente assegura a pressuposição ii. Os efeitos maternos poderiam influenciar as correlações ambientais entre parentes, porém são considerados como ausentes nas estimativas. A suposição de ausência de ligação (iii) apresenta dificuldades quando se estima a covariância entre parentes em que um indivíduo não é o antecessor do outro, por exemplo, a covariância entre meios irmãos ou irmãos completos, porque reduz a freqüência de recombinação para valores inferiores a $1 / 2$. A suposição iv, de que a geração parental não é endogâmica, é satisfeita quando os genitores de cada indivíduo amostrado não tem nenhum antecessor em comum. A suposição $v$ é necessária como base de referência (população de referência) para o propósito de comparação da população que está sendo amostrada com aquela em que os componentes de variância genética se referem. Logo, para que estas variâncias tenham sentido em experimentos de progênies de polinização aberta, é necessário o conhecimento da endogamia e do parentesco (Namkoong, 1966; Squillace, 1974) na população parental e do provável número de polinizadores que contribuíram para as progênies.

Em espécies arbóreas, sementes obtidas de progênies de polinização aberta são esperadas por virem de pólen de um grande número de polimizadores, distribuídos aleatoriamente dentro das populações. Contudo, em muitas espécies, é provável a existência de parentesco, em especial entre árvores vizinhas, devido a, muitas vezes, a dispersão de sementes ocorrer próximo às árvores maternas. Corroborando com esta hipótese, estudos do sistema de reprodução e de estrutura genética intrapopulacional em populações naturais em essências florestais têm revelado a presença de cruzamentos entre aparentados (Reis, 1996; Moraes, 1997; Souza, 1997; Sebbenn et al., 1998; Seoane, et al., 2000; Sebbenn et al., 2000; entre outros), parentesco entre indivíduos espacialmente próximos (Dewey \& Heywood, 1988; Perry \& Knowles, 1991; Schabel et al., 1998; Rogers et al., 1999; Chung et al., 1999; Chung \& Epperson, 2000) e a presença de cruzamentos preferenciais (Sebbenn et al., 1998; Seoane, et al., 2000; Sebbenn et al., 
2000). Também se sabe que estas espécies apresentam depressão por endogamia para alguns caracteres de vigor, sugerindo a presença de dominância e pressão de seleção contra a endogamia (Namkoong, 1966). Mas, em condições de controle experimental, estas forças podem ser minimizadas, como detectados por Libby et al. (1981) para Sequoia sempervirens e por Sneizko \& Zobel (1988) em Pinus taeda, levando à permanência de individuos endógamos nos testes de progênies, o que por sua vez, pode levar a erros nas estimativas da variância genética aditiva $\mathrm{e}$, posteriormente nos parâmetros genéticos. Diante de tais situações, Namkoong (1966) ressalta que a estimativa da variância genética aditiva para o caso de dois alelos não é simplesmente igual à equação 10 , mas torna-se:

$$
\sigma_{A}^{2}=2 p(1-p) \mu^{2}(1+f)\left[1+\frac{1-f}{1+f} a(1-2 p)\right]^{2}
$$

Sendo, $\left[1+\frac{1-f}{1+f} a(1-2 p)\right]^{2}=$ efeito médio de subtituição gênica sob endogamia.

Neste caso, o parâmetro estimado é diferente devido à endogamia, a não ser que: (i) $p=1 / 2$, ou (ii) não exista dominância $(a=0)$. Se isto é verdadeiro, então esta variância genética aditiva estimada sob endogamia $\left(\sigma_{A}^{2}\right)$ é simplesmente $(1+f) \sigma_{A}^{2}$. Além disso, como já citado, as fortes evidências de depressão por endogamia em essências florestais sugerem a existência de algum grau de dominância na herança dos caracteres de crescimento (ver item 2.5). Desta forma, se a estimativa da variância genética de uma população endogâmica é usada para estimar a variância genética de uma população hipotética, não endogâmica (por exemplo, usar $(1+f) \sigma_{A}^{2}$ ' para estimar $\sigma_{A}^{2}$ ), a $\sigma_{A}^{2}$ será subestimada se as freqüências gênicas forem inferiores a $1 / 2$ e superestimada se as freqüências forem maiores que $1 / 2$, para o caso de dominância positiva (dominância dos alelos favoráveis). Quando $a<0$, o heterozigoto é pior que a média dos homozigotos, sendo o inverso também verdadeiro. Em outro caso, a endogamia afeta apenas a magnitude dos vícios, e não a direção. Assim, quanto maior for a endogamia, maior será a sobre ou subestimativa da $\sigma_{A}^{2}$, dependendo de onde $[\mathrm{a}(1-2 p)]$ é negativo ou positivo. Generalizando, a direção desses vícios dependente do nível médio de dominância (a) e da 
frequêencia gênica. Com níveis moderados de dominância e intermediários de frequuências gênicas, os vícios tendem a tornar-se superestimados (Namkoong, 1966).

Assim, as estimativas da $\sigma_{A}^{2}$ podem ser feitas usando material endogâmico, apenas se as freqüências gênicas forem de $1 / 2$ ou não existir dominância e o coeficiente de endogamia $(f)$ for conhecido. Esta origem dos vícios é baseada sobre um parentesco esperado entre os parentais das progênies. Então, se os cruzamentos em uma vizinhança forem todos derivados de uma árvore com muitas origens de pólen, a relação de parentesco entre os filhos pode ser considerada como de meios irmãos e coeficiente $f$ neste caso será $1 / 8$. Se todos os filhos forem o produto de um mesmo pólen parente, o parentesco será de irmãos completos e coeficiente $f$ seria 1/4. Entretanto, se ocorrer autofecundação, o coeficiente $f$ poderá ser de $1 / 2$ (Namkoong, 1966).

Outra origem de erro existe quando a geração parental fornecedora do pólen é aparentada e restrita em número. A restrição severa no número efetivo de polinizadores de uma mesma progênie, aumenta o parentesco médio de individuos nas progênies de polinização aberta (Namkoong, 1966). Contudo, se os polinizadores são aparentados os pares de indivíduos dentro da progênies serão mais aparentados que o grau de meios irmãos (1/4) e menos do que irmãos completos (1/2). Então, se poucos polinizadores dão origem a muitos indivíduos e existe parentesco entre estes, a covariância média dos indivíduos nas progênies excede à covariância de meios irmãos. Se a epistasia é ignorada, a covariância dentro das progênies devido à relação de meios irmãos estima $1 / 4 \sigma_{A}^{2}$, porém estas outras covariâncias de parentes próximos incluiriam proporções de variâncias genéticas aditivas e de dominâncias. Mesmo se os polinizadores não são aparentados com a planta mãe, mas um pequeno número contribui para um grande número de plantas de uma progênie, já ocorre um aumento da covariância entre individuos dentro das progênies e causa uma sobreestimativa da variância aditiva. Este efeito é acentuado com o aumento do parentesco entre os polinizadores, ou seja, aumenta o parentesco dentro das progênies quando os cruzamentos ocorrem entre primos de primeiro grau, meios irmãos, irmãos completos, irmãos de autofecundação, etc. (Namkoong, 1966).

Sorensen \& White (1988) resumiram os principais problemas que podem ocorrer na estimativa de variâncias genéticas em progênies de polinização aberta (Tabela 7). 
Dependendo de quais das pressuposições são violadas, os indivíduos dentro de progênies de polinização aberta podem ser mais ou menos aparentados do que os meios irmãos de populações de cruzamentos aleatónios.

O conhecimento dos coeficientes de parentesco médio entre indivíduos dentro de progênies é essencial para uma eficiente seleção e predição de ganhos em programas de seleção artificial (Surles et al., 1990). Progênies de polinização aberta são muitas vezes geradas por autofecundação e cruzamentos, podendo constituir-se da mistura de três diferentes tipos de parentes: meios irmãos, irmãos completos e indivíduos de autofecundação. A correlação genética média $\left(r_{x y}\right)$ em uma progênie produzida por polinização aberta é a média da correlação entre os parentescos específicos dentro da progênie ponderada pela proporção de cada tipo de parentesco (Squillace, 1974).

A computação da correlação média entre progênies de uma árvore de polinização aberta é complica em condições de campo pelo fato de que os parâmetros envolvidos sobre várias situações não são acuradamente conhecidos. É possível que o número de pais que contribuem para gerar uma progênie de polinização aberta provavelmente esteja entre 5 a 15, devido à limitação na dispersão de pólen, assincronismo no florescimento, comportamento dos polinizadores, etc. (Squillace, 1974).

Squillace (1974) estudou, por simulação, várias situações de parentesco entre polinizadores e níveis de autofecundação, prováveis de ocorrer no campo. $O$ autor observou para uma situação em que os genitores não são aparentados, mas a taxa de autofecundação varia de 0 a $20 \%$, o seguinte: i) a correlação genética aumenta fortemente com o aumento do grau de autofecundação, porém, pouco se o número de diferentes polinizadores é relativamente pequeno; ii) a correlação genética média também aumenta com o tamanho das progênies, mas os efeitos deste tamanho tornam-se pequenos com tamanhos acima de 50 indivíduos e, iii) falhas na suposição de que números iguais de pais geram número iguais de filhos, causam apenas pequenas superestimativas na correlação genética média. 


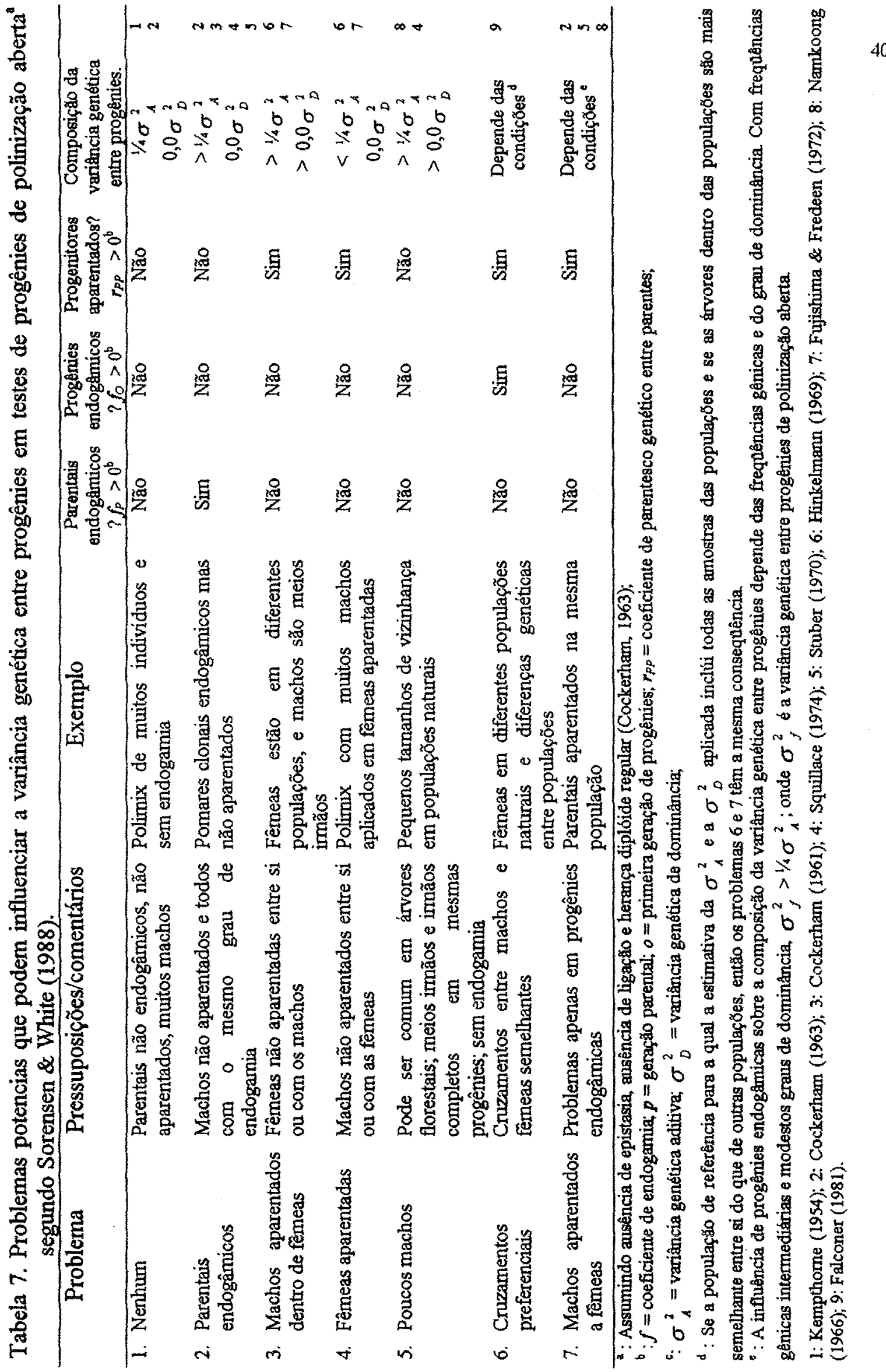


Para uma situação em que os genitores são endogâmicos mas não aparentados e a taxa de autofecundação varia de 0 a $20 \%$, em relação à situação anterior, muda apenas a correlação específica entre indivíduos dentro da progênie, sendo, na média menor. Também, as correlações são menores que nos casos em que existem parentescos entre os genitores.

As implicações são as seguintes: em situações em que existe correlação entre as progênies, ou seja, a geração parental é aparentada, se a estimativa da variância genética aditiva for obtida assumindo que os indivíduos dentro das progênies são meios irmãos (1/4), quando estes não são, resultará em subestimativas da $\sigma_{A}^{2}$ e da herdabilidade no sentido restrito, dado que, $h_{i}^{2}=\frac{\sigma_{A}^{2}}{\sigma_{F}^{2}}(13)$, onde, $\sigma_{F}^{2}$ é a variância fenotípica.

Em um delineamento hierárquico com progênies e indivíduos dentro de progênies, a análise da variância é relativamente simples, assumindo que todos os efeitos genéticos são simplesmente aditivos (Tabela 8).

Tabela 8. Análise da variância para teste de progênies no delineamento inteiramente ao acaso, contendo progênies de polinização aberta.

\begin{tabular}{lccl}
\hline \multicolumn{1}{c}{ FV } & GL & QM & \multicolumn{1}{c}{ E(QM) } \\
\hline Progênies & $J-1$ & $Q M_{f}$ & $\sigma_{d}^{2}+J \sigma_{e}^{2}+J K \sigma_{f}^{2}$ \\
Resíduo & $(I-1)(J-1)$ & $Q M_{e}$ & $\sigma_{d}^{2}+J \sigma_{e}^{2}$ \\
Dentro de progênies & $I J(K-1)$ & $Q M_{d}$ & $\sigma_{d}^{2}$ \\
\hline
\end{tabular}

Sendo: $I=$ número de progênies; $K=$ número de indivíduos dentro de progênies; $J=$ número de repetiçôes; $\sigma_{d}^{2}=$ variância fenotípica dentro de progênies; $\sigma_{f}^{2}=$ variância genética entre progênies; $\hat{\sigma}_{\epsilon}^{2}=$ variância ambiental.

$$
\begin{aligned}
& \sigma_{d}^{2}=Q M_{d}=\left(1-r_{x y}\right) \sigma_{A}^{2}+J \sigma_{e}^{2} . \\
& \sigma_{f}^{2}=\frac{Q M_{f}-Q M_{e}}{J K}=\left(r_{x y}-r_{p p}\right) \sigma_{A}^{2}
\end{aligned}
$$




$$
\sigma_{e}^{2}=\frac{\sigma_{d}^{2}-\left(1-r_{x y}\right) \sigma_{A}^{2}}{J}=\frac{\sigma_{d}^{2}-\left(1-r_{x y}\right)\left(\frac{\sigma_{f}^{2}}{r_{x y}-r_{p p}}\right)}{J}
$$

Onde: $r_{x y}=$ correlação entre individuos dentro de progênies; $r_{p p}=$ correlação entre parentais ou coeficiente de endogamia entre progênies (no caso de equilíbrio de endogamia). Assim, verifica-se que as estimativas de $\sigma_{A}^{2}$ decrescem com o aumento da correlação entre indivíduos dentro de progênies e aumentam conforme aumenta a correlação entre parentais. As correlações afetam as herdabilidades de uma mesma maneira. Substituindo as variâncias dadas na Tabela 8 , dentro da equação usual de herdabilidade individual no sentido restrito:

$$
h_{i}^{2}=\frac{4 \sigma_{f}^{2}}{\left(r_{x y}-r_{p p}\right) \sigma_{d}^{2}+\sigma_{e}^{2}+r_{x y} \sigma_{f}^{2}}
$$

Se os parentais não são aparentados e se a correlação entre os indivíduos dentro das progênies é $1 / 4$, o parentesco é de meios irmãos e a equação 17 reduz-se a

$$
h_{i}^{2}=\frac{\sigma_{f}^{2}}{0,25\left(\sigma_{d}^{2}+\sigma_{\varepsilon}^{2}+\sigma_{f}^{2}\right)}=\frac{4 \sigma_{f}^{2}}{\sigma_{d}^{2}+\sigma_{e}^{2}+\sigma_{f}^{2}}
$$

Esta última expressão têm sido a mais utilizada para conhecer a herança de caracteres quantitativos de essências florestais, quando se utilizam progênies de polinização aberta, devido a existência de poucos dados sobre a correlação genética dentro de progênies (Surles et. al., 1990). Observa-se que as estimativas da herdabilidade podem ser ajustadas para a correlação entre parentais $\left(r_{p p}\right)$ e entre individuos dentro de progênies $\left(r_{x y}\right)$. Se os parentais são assumidos por não serem aparentados, quando na verdade eles são, as estimativas da herdabilidade ficam subestimadas, como já comentado (Squillace, 1974; Surles et al., 1990). Em contraste, assumindo que a covariância entre indivíduos dentro de progênies é $1 / 4$, quando esta é maior, obtém-se estimativas de herdabilidades superestimadas. No caso em que se assume que a correlação entre parentais é zero e entre indivíduos dentro de progênies é de $1 / 4$, a estimativa da 
herdabilidade fica superestimada. Contudo, a superestimativa é menor se existe parentesco entre os genitores, mas neste caso uma significante subestimativa pode ocorrer quando a taxa de autofecundação é alta e a herdabilidade é baixa. Por outro lado, se os parentais não são aparentados (tais como em alguns plantios artificiais ou pomares clonais) a herdabilidade é apreciadamente superestimada, especialmente se a taxa de autofecundação for alta (Squillace, 1974). Surles et al. (1990) observaram que a estimativa da herdabilidade em progênies de polinização aberta de Robinia pseudoacacia, uma espécie arbórea do oeste dos Estados Unidos, ficou superestimada em 38\% quando a correlação genética dentro de progênies foi considerada como de meios irmãos $\left(r_{x y}=0,25\right)$, relativamente à situação em que foi utilizada a verdadeira correlação genética $(0,34)$. Já, quando Surles e seus colaboradores acrescentaram a correlação de parentesco da geração parental $\left(r_{p p}\right)$, as superestimativas diminuíram. Finalmente, quando os autores combinaram as informações da correlação entre indivíduos dentro de progênies $\left(r_{x y}\right)$, a correlação genética $\left(r_{p p}\right)$ e o coeficiente de endogamia da geração parental $\left(f_{p}\right)$, os ganhos preditos ficaram superestimados em $11 \%$. Em progênies de polinização aberta é muito provável que ocorram misturas de irmãos completos, meios irmãos e indivíduos de autofecundação e que exista algum grau de parentesco e endogamia em populações naturais, portanto parece sábio ajustar-se as estimativas de herdabilidades, quando da utilização de tais tipos de progênies (Squillace, 1974). Diante de tais situações, Hamrick (1976) sugere que se utilize a correlação genética de 1/3 entre progênies.

É importante que se saiba que, na realidade, a correlação genética e o coeficiente de endogamia variam amplamente entre diferentes progênies, assim os coeficientes de herdabilidade para ambos, entre e dentro de progênies, podem ser específicos para cada progênie, em especial para herdabilidade entre indivíduos dentro de progênies. De modo geral, variações entre árvores na taxa de cruzamento e a distribuição dos genótipos maternos nas populações podem afetar a proporção de parentesco das progênies (autofecundação, irmãos completos e meios irmãos) em sementes coletadas de polinização aberta (Surles et al., 1990). 


\subsection{Componentes da Variâncla Genética na Presença de Sistema Misto de REPRODUÇão}

Até rescentemente, toda a teoria desenvolvida para a estimativa de componentes de variância e parâmetros genéticos em programas de melhoramento era baseada na suposição de total autogamia ou alogamia. Contudo, com o advento dos marcadores moleculares e os avanços no deservolvimento de modelos genéticos estatísticos para descrever os eventos reprodutivos, sabe-se hoje, que muitas das espécies arbóreas assumidas como alógamas, são na realidade de reprodução mista, como por exemplo, várias espécies do gênero Eucalyptus (Eldridge, 1978; Moran \& Brown, 1980; Moran et al., 1989; Eldridge, 1993) e Pinus (Sorensen \& Miles, 1982; Squillace \& Goddard, 1982; Morgante et al., 1993; Changtragoon \& Finkeldey, 1995; Burczyk, 1998). Da mesma forma, a grande maioria das espécies arbóreas tropicais estudadas têm-se mostrado como de reprodução mista (ver Tabelas 49 a 52 em anexo).

O parentesco entre dois membros de uma progênie pode ser afetado pelo sistema de reprodução de várias formas. Se ocorrer autofecundação em uma taxa $s$, a probabilidade dos pais de dois filhos retirados aleatoriamente de uma progênie serem idênticos é $s^{2}$. Esta identidade aumenta o parentesco acima do esperado com cruzamentos aleatórios. Alem disso, se os filhos tendem a ser todos de autofecundação ou todos de cruzamentos e, conseqủentemente, mostram uma positiva correlação de autofecundação $\left(\hat{r}_{s}\right)$, seu parentesco médio é aumentado, e seus pais são idênticos com uma probabilidade maior do que $s^{2}$. Ainda, o parentesco em uma progênie aumenta quando o número de pais que contribuíram para a formação dos filhos diminui, ou equivalentemente, quando a correlaçăo de paternidade $\left(\hat{r}_{p}\right)$ nos cruzamentos aumenta. Em espécies parcialmente de autofecundação todos os três fatores (autofecundação, correlação de autofecundação e correlação de paternidade de cruzamentos) podem estar presentes (Ritrand, 1989).

Diante disso, modelos exclusivamente para espécies alógamas ou autógams tornam-se inadequados para a estimativa de componentes de variância e parâmetros genéticos. Weir \& Cockerham (1977) derivaram as expressões para as estimativas da variância genética e covariância entre parentes, baseada em um modelo de dois locos, que 
incluía epistasia, ligação gênica e endogamia, em uma população parcialmente autógama em equilíbrio de endogamia. A suposição de equilibrio garantia que toda a endogamia observada fosse atribuída ao sistema reprodutivo. No entanto, as expressões obtidas pelos autores foram tão complexas, que sua utilização prática é quase impossível.

Posteriormente, Ghai (1982) desemvolveu um modelo para a estimativa de variância e covariância entre parentes para populações parcialmente autógamas, que incluia variações na taxa de autofecundação, qualquer frequiência alélica e dois alelos por locos. Apesar da simplicidade do modelo de Ghai, ele tinha a desvantagem de fazer com que a variância aditiva e de dominância variassem com a taxa de autofecundação, ser restrito a um loco com dois alelos e não se saber como as covariâncias encontradas se relacionam com o ganho genético permanente. Alem disso, o modelo de Ghai (1982) não levava em conta o desequilibrio inter-locos nem a variação na taxa de endogamia e suas conseqüências nas variâncias e covariâncias genéticas (Cockerham \& Weir, 1984).

Por isso, Cockerham \& Weir (1984) desenvolveram um modelo para populações em equilíbrio de endogamia, acomodando efeitos aditivos e de dominância, qualquer número de locos e alelo e variação na taxa de endogamia, mas desconsiderando a presença de ligação gênica e epistasia:

$$
G_{i j k}=a_{i j}+a_{i k}+d_{i j k} .
$$

Neste modelo, o efeito gênico em um indivíduo $G_{i j k} \operatorname{com}$ os alelos $j$ e $k$ no loco $i$ tem o valor genotípico $a_{j i}, a_{k i}$ e $d_{j k}$, onde o $a$ é o efeito aditivo e $d$ é o efeito de dominância. Os efeitos dos termos $a$ e $d$ são definidos para uma população idealizada não endogâmica (Cockerham \& Weir, 1984). Se $p_{j i}$ é a freqüência do alelo $j$ no loco $i$, então tem-se os componentes quadráticos apresentados na Tabela 9.

Sendo $H^{*}$ a depressão por endogamia e $H^{2}$ o quadrado da depressão por endogamia.

Algumas apreciaç⿸̃es da magnitude destas quantidades podem ser obtidas considerando o caso de dois alelos por loco. Assim, assumindo-se apenas dois alelos em um loco, pode-se simplificar utilizando $D_{2}^{*}=D_{2}-H^{*}$, que é a variância total dos efeitos de dominância dos homozigotos. Se os três genótipos do i-ésimo loco são $A_{k} A_{i}, A_{l} a_{i}$ 
e $a_{i} a_{i}$, com valores genotípicos $1, d_{i}$ e -1 , respectivamente, (onde $d_{i}=1$ indica completa dominância de $A_{1}$ sobre $a_{i}$ e $d_{i}=0$ indica ausência de dominância) e a freqũência gênica de $A_{i}$ é $p_{j}$, então,

$$
\begin{aligned}
& \sigma_{A}^{2}=2 \sum_{i} p_{i}\left(1-p_{i}\right)\left[1+\left(1-2 p_{i}\right) d_{i}\right]^{2} \\
& \sigma_{D}^{2}=H^{*}=4 \sum_{i} p_{i}^{2}\left(1-p_{i}\right)^{2} d_{i}^{2} \\
& D_{1}=-2 \sum_{i} p_{i}\left(1-p_{i}\right)\left(1-2 p_{i}\right) d_{i}\left[1+\left(1-2 p_{i}\right)\right] \\
& D_{2}^{*}=4 \sum_{i} p_{i}\left(1-p_{i}\right)\left(1-2 p_{i}\right)^{2} d_{i}^{2} \\
& H^{2}-H^{*}=4 \sum_{i \neq} \sum_{j} p_{i}\left(1-p_{i}\right) p_{j}\left(1-p_{j}\right) d_{i} d_{j}
\end{aligned}
$$

Tabela 9. Componentes quadráticos da variância genética, segundo Weir \& Cockerham (1984).

\begin{tabular}{lcc}
\hline Componentes da variância & Um loco & Somatónio dos locos \\
\hline Variância aditiva $\left(\sigma_{A}^{2}\right)$ & $2 \sigma_{a i}^{2}=2 \sum_{j} p_{j i} a_{j i}^{2}$ & $\sigma_{A}^{2}=\sum_{i} 2 \sigma_{a i}^{2}$ \\
Variância de dominância $\left(\sigma_{D}^{2}\right)$ & $\sigma_{d i}^{2}=\sum_{j} \sum_{k} p_{j i} p_{k i}\left(d_{j k i}\right)^{2}$ & $\sigma_{D}^{2}=\sum_{i} \sigma_{d i}^{2}$ \\
Covariância $a_{j}$ e $d_{j j}$ & $d_{1 i}=\sum_{j} p_{j i} a_{j i} d_{j i}^{j}$ & $D_{1}=\sum_{i} d_{i i}$ \\
Quadrados médios de $d_{j j}$ & $d_{2 i}=\sum_{j} p_{j i}\left(d_{j i}^{j}\right)^{2}$ & $D_{2}=\sum_{i} d_{2 i}$ \\
Depressão por endogamia & $h_{i}=\sum_{j} p_{j i} d_{j i}^{j}$ & $H^{2}=\left(\sum_{i} h_{i}\right)^{2}$ \\
& & $H^{*}=\sum_{i} h_{i}^{2}$ \\
\hline
\end{tabular}

Se todos os alelos são igualmente freqüentes, $D_{1}=D_{2}^{*}=0$. Dos quatro termos que são somados sobre os locos, apenas o $D_{1}$ pode ser negativo, dependendo da frequêencia gênica e do sentido $e \mathrm{da}$ intensidade de dominância, já que este componente corresponde a uma covariância entre efeitos aditivos e de dominância dos homozigotos. O 
coeficiente deste componente quadrático é $4 f_{p}\left(f_{p}=\right.$ coeficiente de endogamia da geração parental), podendo chegar a ser o dobro do coeficiente da variância aditiva, assim interferindo de forma negativa nos progressos genéticos (Pereira, 1997). $D_{1}$ será negativo quando a freqüência dos alelos favoráveis for $p_{i}<0,5$ e positivo quando $p_{i}>0,5$, quando a dominância é positiva. Também, $H^{2}-H^{*}$ pode ser negativo, dependendo da mistura de efeitos de dominância, porém, com dominância geral direcional (por exemplo, com o termo $d$ de mesmo sinal) este componente pode ser muito grande, relativamente a outros componentes, devido ao somatório sobre todos os pares de locos (Cockerham \& Weir, 1984).

De acordo com este modelo, a variância genética total $\left(\sigma_{O F}^{2}\right)$ para quaisquer dois indivíduos, com qualquer grau de endogamia na geração parental $\left(f_{p}\right)$, em espécies alógama, mista e autógama, é segundo Cockerham \& Weir (1984):

a) Espécies alógamas $\left(f_{p}=0\right.$ )

$$
\sigma_{C o}^{2}=\sigma_{A}^{2}+\sigma_{D}^{2}
$$

b) Espécies de Sistema Misto

$$
\sigma_{\alpha^{*}}^{2}=\left(1+f_{p}\right) \sigma_{A}^{2}+\left(1-f_{p}\right) \sigma_{D}^{2}+4 f_{p} D_{1}+f_{p} D_{2}^{*}+f_{p}\left(1-f_{p}\right) H^{*}+\left(\widetilde{f_{p}}-f_{p}^{2}\right)\left(H^{2}-H^{*}\right)
$$

c) Espécies autógamas $\left(f_{p}=1\right)$

$$
\sigma_{O 1}^{2}=2 \sigma_{A}^{2}+4 D_{1}+D_{2}^{*}
$$

Sendo $f_{p}$ o coeficiente de endogamia em equilibrio de endogamia na geração parental, podendo ser obtido tanto pela taxa de autofecundação $(s)$ como de cruzamento( $(t)$ :

$$
f_{p}=\frac{s}{2-s}=\frac{1-t}{1+t}
$$

A covariância entre quaisquer dois parentes $\left(C V_{x y}\right)$ pode ser expressa pela utilização de medidas de identidades por descendência e pelos seguintes componentes quadráticos: 


$$
\begin{aligned}
& C O V_{X Y}=2 \theta_{X Y} \sigma_{A}^{2}+2\left(\Delta_{\tilde{X}+\ddot{Y}}-\delta_{\ddot{X Y}}\right) \sigma_{D}^{2}+2\left(\gamma_{\ddot{X Y}}-\gamma_{X \dot{Y}}\right) D_{1}+\ldots \\
& \ldots+\delta_{\ddot{X Y}} D_{2}^{*}+\left(\Delta_{\ddot{X} .}-f_{X} f_{Y}\right) H^{*}+\left(\Delta_{X Y}-f_{X} f_{Y}\right)\left(H^{2}-H^{*}\right)
\end{aligned}
$$

Para os últimos termos têm-se assumido que não existe ligação (Cockerham \& Weir, 1984). Entretanto, para a estimativa de todos os componentes quadráticos é necessária a obtenção de quatro tipos de progênies e a avaliação dos parentais juntamente com as progênies, a fim de obter-se as covariância entre parentes: $C O V_{P M, P A}=$ covariância entre pais e filhos de cruzamento; $C O V_{P M, A F}=$ covariância entre pais e filhos de autofecundação; $C O V_{A F, A F}=$ covariância entre irmãos de autofecundação; $C O V_{A F, P A}=$ covariância entre irmãos de autofecundação e de cruzamento; $C O V_{X C, C}=$ covariância entre irmãos completos; $C O V_{P A, P A}=$ covariância entre irmãos de polinização aberta.

Estas covariâncias podem ser melhor visualizadas a partir do diagrama da Figura 1. Os coeficientes dos componentes quadráticos das variâncias ou covariâncias (Tabela 10) podem ser obtidos por cálculos de medidas de identidade por descendência, com base em uma população endogâmica, podendo ser definida tanto pelo coeficiente de endogamia $\left(f_{p}\right)$ da geração parental como pela taxa de autofecundação $(s)$.
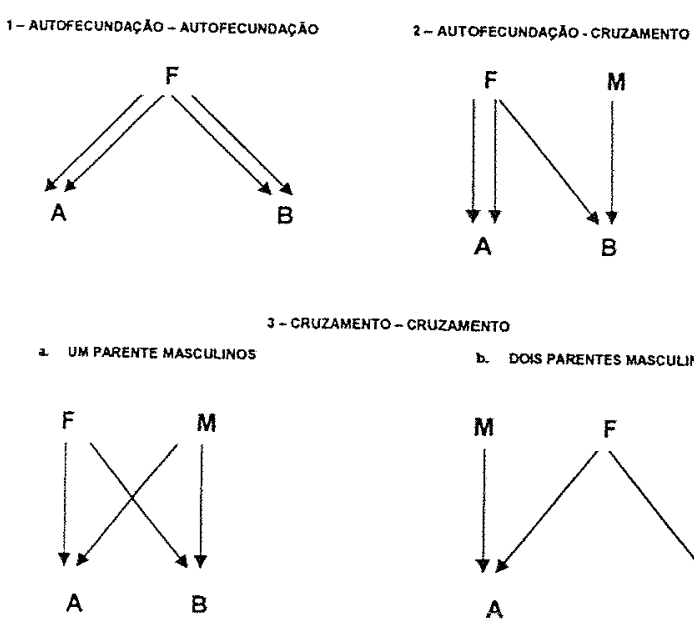

- CRUZAMENTO- CRUZAMENTO

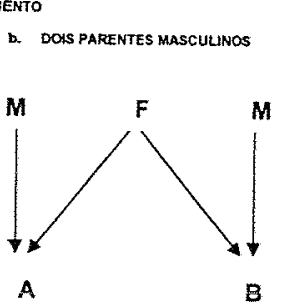

Figura 1 - Diagrama de cruzamentos: (1) irmãos de autofecundação; (2) irmãos de autofecundação e de cruzamento; (3a) irmãos completos; (3b) meios irmãos. 
Tabela 10. Medidas de parentesco referentes aos diagramas da Figura 1 e outras relações.

\begin{tabular}{|c|c|c|c|c|c|c|}
\hline \multirow{2}{*}{$\begin{array}{l}\text { Medides de } \\
\text { parentesco }\end{array}$} & \multicolumn{6}{|c|}{ Covariâncias entre parentes } \\
\hline & $C O V_{P M, P A}$ & $C O V_{P M L A F}$ & $C O V_{A F A F}$ & $C O V_{A B, P A}$ & $C O V_{I C, I C}$ & $C O V_{P A, P A}$ \\
\hline$f_{x}$ & $f_{p}$ & $f_{p}$ & $\frac{1}{2}\left(1+f_{p}\right)$ & $\frac{1}{2}\left(1+f_{p}\right)$ & 0 & 0 \\
\hline$f_{y}$ & 0 & $\frac{1}{2}\left(1+f_{p}\right)$ & $\frac{1}{2}\left(1+f_{p}\right)$ & 0 & 0 & 0 \\
\hline$\theta_{x y}$ & $\frac{1}{4}\left(1+f_{p}\right)$ & $\frac{1}{2}\left(1+f_{p}\right)$ & $\frac{1}{2}\left(1+f_{r}\right)$ & $\frac{1}{4}\left(1+f_{F}\right)$ & $\frac{1}{4}\left(1+f_{p}\right)$ & $\frac{1}{8}(1+f)$ \\
\hline$\gamma_{z y}$ & 0 & $f_{p}$ & $\frac{1}{4}\left(1+3 f_{p}\right)$ & $\frac{1}{8}\left(1+3 f_{p}\right)$ & 0 & 0 \\
\hline$\gamma_{x y}$ & 0 & $\frac{1}{4}\left(1+3 f_{p}\right)$ & $\frac{1}{4}\left(1+3 f_{z}\right)$ & 0 & 0 & 0 \\
\hline$\Delta_{x y y}$ & 0 & $f_{\rho}$ & $\frac{1}{4}(1+3 f)$, & 0 & 0 & 0 \\
\hline$\Delta_{\ddot{x+y}}$ & 0 & $\frac{1}{4}\left(1+3 f_{p}\right)$ & $\frac{1}{4}\left(1+3 f_{p}\right)$ & 0 & $\frac{1}{8}\left(1+f_{p}\right)^{2}$ & 0 \\
\hline$\delta_{x y y}$ & 0 & $f_{p}$ & $\frac{1}{8}\left(1+7 f_{p}\right)$ & 0 & 0 & 0 \\
\hline$\tilde{\Delta}_{x, y}$ & 0 & $\frac{1}{2}\left(1+\widetilde{f}_{p}\right)$ & $\frac{1}{4}\left(1+2 f_{p}+\widetilde{f}_{p}\right)$ & 0 & 0 & 0 \\
\hline
\end{tabular}

Fonte: Cockerham \& Weir (1984);

Obs: $f_{p}$ corresponde a $F$, no modelo original de Cockerham \& Weir (1984).

Com cruzamentos controlados, os vários tipos de indivíduos (meios irmãos, irmãos completos, individuos de autofecundação e irmãos de autofecundação e de cruzamento) podem ser obtidos e suas covariâncias estimadas. Quatro covariâncias (COV $V_{P M, P A}$; $C O V_{A F, P A}, C O V_{I C, Y C}$ e $\left.C O V_{P A, P A}\right)$ envolvem apenas três componentes e estes podem ser estimados como:

$$
\begin{gathered}
\hat{\sigma}_{A}^{2}=\left(\frac{4}{1+f_{p}}\right) \operatorname{COV} V_{P A, P A} \\
\hat{\sigma}_{D}^{2}=\left(\frac{4}{\left(1+f_{p}\right)^{2}}\right)\left(C O V_{I C, I C}-2 C O V_{P A, P A}\right) \\
\hat{D}_{1}=\left(\frac{4}{1+7 f_{p}}\right)\left(C O V_{P A, P A}+C O V_{A P, P A}-4 C O V_{P A, P A}\right)
\end{gathered}
$$

O componente $H^{2}$, que se refere à depressão por endogamia, não pode ser estimado diretamente, sendo obtido a partir da média das progênies de cruzamento $\left(m_{t}\right)$ e de autofecundação $\left(m_{s}\right)$ : 


$$
\begin{aligned}
& \hat{H}=\left(\begin{array}{c}
2 \\
1+f_{p}
\end{array}\right)\left(m_{t}-m_{s}\right) \\
& \hat{H}^{2}=\hat{H}^{2}=\left\{\frac{2}{\left(1+f_{p}\right)^{2}}\right\}\left(\hat{\sigma}_{m_{t}}^{2}-\hat{\sigma}_{m_{s}}^{2}\right)
\end{aligned}
$$

Em que $\hat{H}^{2}$ é um estimador não viciado de $H^{2}$ e $\hat{\sigma}_{m}^{2}$ e $\hat{\sigma}_{m_{s}}^{2}$ são as variâncias dos erros residuais das médias das progênies de cruzamento $(t)$ e de autofecundação $(s)$ (Cockerham \& Weir, 1984).

Os coeficientes dos componentes quadráticos na Tabela 11 podem ser facilmente obtidos, substituindo-se as medidas de parentesco apresentadas na Tabela 10 dentro da equação 29.

Tabela 11. Coeficientes dos componentes quadráticos na covariância de parentes em populações com sistema misto de reprodução, segundo Cockerham \& Weir

\begin{tabular}{|c|c|c|c|c|c|c|}
\hline Covariâncias & $\sigma_{A}^{2}$ & $\sigma_{D}^{2}$ & $\overline{D_{1}}$ & $D_{2}{ }^{*}$ & $H^{*}$ & $H^{2}-H^{*}$ \\
\hline$C O V_{P M, P A}$ & $\frac{1}{2}(1+f)$, & 0 & $f_{p}$ & 0 & 0 & 0 \\
\hline$C O V_{P M_{A} A F}$ & $1+f_{p}$ & $\frac{1}{2}\left(1+f_{p}\right)$ & $\frac{1}{2}\left(1+7 f_{2}\right)$ & $f_{p}$ & $\frac{1}{2}\left[f_{p}\left(1-f_{p}\right)\right]$ & $\frac{f_{\nu}\left(1-f_{\nu}{ }^{2}\right)}{2\left(2+f_{p}\right)}$ \\
\hline$C O V_{A F, A F}$ & $1+f_{p}$ & $\frac{1}{4}\left(1-f_{n}\right)^{2}$ & $1+3 f_{p}$ & $\frac{1}{8}\left(1+7 f_{p}\right)$ & $\frac{1}{4}\left[f,\left(1-f_{,}\right)\right]$ & $\frac{f_{r}\left(1-f_{P}^{2}\right.}{4\left(2+f_{r}\right)}$ \\
\hline$C O V_{A F, P A}$ & $\frac{1}{2}(1+f)$, & 0 & $\frac{1}{4}(1+3 f)$, & 0 & 0 & \\
\hline$C O V_{I C, S C}$ & $\frac{1}{2}(1+f)$ & {$\left[\frac{1}{2}\left(1+f_{r}\right)\right]^{2}$} & 0 & 0 & 0 & 0 \\
\hline$C O V_{P A, P A}$ & $\frac{1}{4}(1+f)$ & 0 & 0 & 0 & 0 & 0 \\
\hline
\end{tabular}
(1984).

Contudo, Cockerham \& Weir (1984) ressaltaram que na ausência de dominância todas estas covariâncias reduzem-se a:

$$
\operatorname{COV}_{X Y}=2 \theta_{X Y} \sigma_{A}^{2}=r_{x y} \sigma_{A}^{2}
$$


No entanto, devido ao esquema de parentesco de Cockerham \& Weir (1984) exigir a obtenção de quatro tipos de progênies e a avaliação das plantas maternas e de progênies, sua aplicação é práticamente impossível (Ferreira, 2000).

Infelizmente, o modelo de Cockerham \& Weir (1984), pressupõe que a população encontra-se em equilibrio de Wright, o que nem sempre é realidade. Populações de reprodução mista levam mais de uma geração de polinização livre para atingir o equilibrio. Espécies com taxa de autofecundação variando de 10 a 30\%, o caso mais comum em essências florestais, precisam de 2 gerações de polinização livre para atingir o equilibrio (Pereira, 1997).

Mais rescentemente, Ritland (1989), propôs um método baseado simultaneamente em estimativas de componentes de variância a partir de dados de caracteres quantitativos e dos coeficientes de parentesco a partir de marcadores genéticos. Para tanto, o autor utilizou um método baseado na probabilidade de pares de filhos serem irmãos de autofecundação ou irmãos completos, denominando de "modelo de simples pares de irmãos".

Este modelo é baseado nos seguintes fatores. Se uma amostra de dois indivíduos é retirada aleatoriamente de um conjunto de fithos de uma mesma mãe, em uma população de autofecundação parcial, estes indivíduos podem ser ambos de autofecundação, um de autofecundação e um de cruzamento ou ambos de cruzamento (meios irmãos e irmãos completos). Com respeito a essas três classes, elas podem apresentar excesso de indivíduos de autofecundação em relação ao esperado aleatoriamente (ambos irmãos são de autofecundação) ou uma correlação de autofecundação entre os dois irmãos (um de autofecundação e um de cruzamento). Alem disso, se os cruzamentos não forem aleatórios na população, os pares de indivíduos podem ser divididos dentro de dois conjuntos, um conjunto com um só parente patemo (irmãos completos) e outro de diferentes parentes paternos (meios irmãos). Ver Figura 1. 
Para descrever a freqüência destes eventos de reprodução, Ritland (1989) introduziu dois parâmetros de correlação do sistema de reprodução. O primeiro $r_{s}$ é a correlação de autofecundação entre dois irmãos (que é igual a covariância de autofecundação, dividida por $s[1-s]$ ), onde $s$ é a taxa de autofecundação. Por exemplo, ser $r_{s}$ é igual a 1 , então os pares de irmãos nas progênies săo ambos igualmente de autofecundação ou ambos de cruzamento. O segundo parâmetro $r_{p}$ é a correlação paterna de cruzamentos entre dois irmãos, ou a correlação de irmãos completos entre irmãos de cruzamento. Estes parâmetros permitem que se estime as freqüências dos quatro tipos de eventos reprodutivos especificados na Tabela 12.

Tabela 12. Probabilidades de eventos reprodutivos em um modelo de pares de irmãos de Ritland (1989).

\begin{tabular}{ll}
\hline \multicolumn{1}{c}{ Evento reprodutivo } & \multicolumn{1}{c}{ Probabilidade } \\
\hline Ambos de autofecundação & $s^{2}\left(1-r_{s}\right)+s r_{s}$ \\
Um de autofecundação e um de cruzamento & $2 s t\left(1-r_{s}\right)$ \\
& \\
Ambos de cruzamento & {$\left[t^{2}\left(1-r_{s}\right)+t r_{s}\right] r_{p}$} \\
$\quad$ Um parental masculino & {$\left[t^{2}\left(1-r_{s}\right)+t r_{s}\right]\left(1-r_{p}\right)$} \\
\hline
\end{tabular}
$t=(1-s)$.

A correlação de genótipos paternos $\left(r_{p}\right)$ é obtida em função de $f_{p}$ ou correlação de gametas paternos, ou ainda da probabilidade de identidade por descendência de gametas paternos derivados em duas progênies.

$$
r_{p}=\left(\frac{2}{1+f_{p}}\right) f
$$

Sendo $f_{p}$ e $f$ o coeficiente de endogamia dos parentais e dos filhos, respectivamente.

É importante que se considere os efeitos dos cruzamentos correlacionados sobre as covariâncias de caracteres quantitativos em programas de melhoramento. A maior importância do modelo de simples pares é que a covariância entre pares de filhos pode ser especificada pelos parâmetros do modelo de sistema de reprodução. Em outros termos, 
estas covariâncias genéticas determinam o potencial efetivo de seleção sobre caracteres quantitativos (Ritland, 1989). Assim, cada par de cruzamentos gera um simples par de irmãos $X$ e $Y$ com uma certa combinação de covariâncias, escritas como:

$$
\operatorname{COV} V_{x y}=C_{1} \operatorname{Var}\left(\alpha_{i}\right)+C_{2} \operatorname{Var}\left(\delta_{i j}\right)+C_{3} \operatorname{COV}\left(\alpha_{i j} \delta_{i j}\right)+C_{4} \operatorname{Var}\left(\delta_{i j}\right)+C_{5} E^{2}\left(\delta_{i j}\right)
$$

Onde os termos $C_{i}$ correspondem aos coeficientes dos componentes quadráticos de covariância e são funções dos tipos de cruzamentos (Tabela 10). Desta tabela e da parametrização dos cruzamentos na Tabela 14, a covariância genética média entre dois irmãos $X$ e $Y$ ou a variância genética entre progênies $\left(\sigma_{f}^{2}\right)$ em uma população praticando cruzamentos correlacionados é, segundo Ritland (1989):

$$
\begin{aligned}
& C O V_{x y}=\sigma_{f}^{2}=\frac{1}{4}(1+\hat{f})\left[4 \hat{s}+\left(\hat{t}^{2}+\hat{s} \hat{t} \hat{r}_{s}\right)\left(1+\hat{r}_{p}\right)\right] \hat{\sigma}_{A}^{2} \\
& \left.\left.+\frac{1}{4}(1-\hat{f})\left[\hat{s}^{2}+\hat{s} \hat{t} \hat{r}_{s}\right)+(1+\hat{f})^{2} \cdot\left(\hat{t}^{2}+\hat{s} \hat{t} \hat{r}_{s}\right) \hat{r}_{p}\right)\right] \hat{\sigma}_{D}^{2} \\
& +\frac{1}{2}\left[(1+3 \hat{f})\left(\hat{s}+\hat{s}^{2}+\hat{s} \hat{t} \hat{r}_{s}\right)\right] \mathrm{D}_{1}+\frac{1}{4}\left[\hat{f}(1-\hat{f})\left[\hat{s}^{2}+\hat{s} \hat{t} \hat{r}_{s}\right)\right] \mathrm{D}_{2} \\
& +\frac{1}{8}\left[(1+7 \hat{f})\left[\hat{s}^{2}+\hat{s} \hat{t} \hat{r}_{s}\right)\right] \breve{H}
\end{aligned}
$$

Onde: $f_{p}=$ coeficiente de endogamia na geração parental; $s=$ taxa de autofecundação; $t=$ taxa de cruzamento; $r_{s}=$ correlação de autofecundação; $r_{p}=$ correlação de paternidade; $\sigma_{A}^{2}=$ variância genética aditiva; $\sigma_{D}^{2}=$ variância de dominância; $D_{1}=$ covariância entre efeitos aditivos e de dominância dos homozigotos; $D_{2}=$ variância genética dos efeitos de dominância dos homozigotos; $\delta_{x y}=$ depressão por endogamia.

Esta covariância entre irmãos é uma função de nove fatores: quatro parâmetros de endogamia e sistema de reprodução e cinco componentes de variância genética. Inspecionando a equação 38, verifica-se que a correlação de paternidade $\left(r_{p}\right)$ afeta apenas a covariância aditiva e de dominância, enquanto a correlação de autofecundação $\left(r_{s}\right)$ afeta todos os componentes de covariância genética. Assim, aumentando a correlação de paternidade aumentam-se ambas covariâncias aditivas e de dominância, e este aumento é 
incrementado com autofecundação parcial. Aumentando a correlação de autofecundação aumentam-se todos os componentes de covariância. Geralmente, em populações de taxas intermediárias de autofecundação, a correlação de autofecundação é mais importante, devido a esta sempre ser multiplicada por $s t$, que é maximizado com $s=t=0,5$. Esta equação também mostra que se ocorrerem cruzamentos correlacionados em uma população para a qual um simples sistema de reprodução é assumido, as estimativas das variâncias genéticas ficarão viciadas (Ritland, 1989). 


\section{MATERIAL E MÉTodos}

\subsection{LOCALS DE ESTUDO}

No ano de 1981, o Instituto Florestal de São Paulo coletou sementes de C. legalis, em três populações naturais do Estado de São Paulo: Campinas (Bosque dos Jequitibás Lat. $22^{\circ} 55^{\prime}$ 'S., Long. $47^{\circ} 03^{\prime}$ 'W., alt. 652 a $681 \mathrm{~m}$, área $\cong 10 \mathrm{ha}$ ), Piracicaba (Estação Ecológica de Ibicatu - Lat. $22^{\circ} 47^{\prime}$ S., Long. $47^{\circ} 49^{\prime}$ W., alt. $500 \mathrm{~m}$, área $\cong 76$ ha) e Santa Rita do Passa Quatro (Parque Estadual da Vassununga - Lat. $21^{\circ} 41^{\prime}$ S., Long. $47^{\circ} 39^{\prime}$ W., alt. de 520 a $700 \mathrm{~m}$, área $\cong 191,0$ ha), sendo estas populações denominadas de Campinas, Ibicatu e Vassununga, respectivamente. Na população Campinas, foram coletadas sementes de 17 matrizes de polinização aberta; na Ibicatu, de 16 matrizes e; na Vassununga, de 22 matrizes. Nas populações Campinas e Ibicatu a coleta foi feita em todas as árvores, tratando-se assim de um censo. Na população Vassununga, a amostragem foi de aproximadamente 7,3\% (22 de 300). Em 1982 as progênies foram plantadas na Estação Experimental de Pederneiras (Lat. 22 $22^{\circ}$ ' S., Long. $48^{\circ} 44^{\prime}$ W., alt. $500 \mathrm{~m}$, precipitação média anual de $1.112 \mathrm{~mm}$, solo do tipo latossolo amarelo, fase arenosa e clima do tipo Cwa) e Estação Experimental de Luiz Antonio (Lat. $21^{\circ} 40^{\prime} \mathrm{S}$., Long. $47^{\circ} 49^{\prime}$ W., alt. $550 \mathrm{~m}$, precipitação média anual de $1.280 \mathrm{~mm}$, solo do tipo latossolo roxo e clima do tipo $(w a)$. O objetivo inicial deste ensaio foi a conservação $e x$ situ de C. legalis.

\subsection{Delineamento EXPERimental}

O delineamento adotado foi o de blocos de familias compactas (Wright, 1978), com 6 repetições, sub-parcelas lineares com 5 plantas e uma bordadura externa de duas linhas. Contudo, devido ao pequeno número de mudas produzidas para 5 progênies da 
população Vassununga, em Pederneiras esta população foi representada por 22 progênies e em Luiz Antonio por 17. Assim, cada uma das 50 progênies comuns aos dois locais estava representada por 60 plantas, sendo $30 \mathrm{em}$ cada local. Já as 5 progênies testadas apenas em Pederneiras estavam representadas por 30 individuos cada (Tabela 15). $\mathrm{O}$ espaçamento utilizado nos dois ensaios foi o 3,0 × 2,0 metros. Não foi utilizada adubação na implantação dos ensaios, porém, em Luiz Antonio foi realizada uma destama, na idade de 8 anos (1990).

\subsection{AMOSTRAGEM}

Os ensaios foram avaliados por cinco caracteres quantitativos e quatorze locos isoenzimáticos.

\subsubsection{Caracteres Quantitativos}

Os caracteres avaliados foram: forma do fuste (FF), altura total (ALT), diâmetro à altura do peito (DAP - 1,3m), volume cilíndrico (VC) e sobrevivência (SOB), aos 17 anos de idade (1999). O número de plantas medidas encontra-se na Tabela 13.

Tabela 13. Características do ensaio e amostragem para os caracteres quantitativos em $C$. legalis. Delineamento em blocos de famílias compactas.

\begin{tabular}{lcccccccc}
\hline População & Progênies & $\begin{array}{c}\text { Planta/ } \\
\text { Parcela }\end{array}$ & $\begin{array}{c}\text { Blocos/ } \\
\text { Locais }\end{array}$ & $\begin{array}{c}\text { Plantal } \\
\text { Prog/Loc }\end{array}$ & $\begin{array}{c}\text { Locais } \\
\text { Plantas/ } \\
\text { Progênie }\end{array}$ & $\begin{array}{c}\text { Plantas/ } \\
\text { Locais }\end{array}$ & Total \\
\hline Campinas & 17 & 5 & 6 & 30 & 2 & 60 & 510 & 1.020 \\
Ibicatu & 16 & 5 & 6 & 30 & 2 & 60 & 480 & 960 \\
Vassununga & $22^{\mathrm{a}}-17^{\mathrm{b}}$ & 5 & 6 & 30 & 2 & 60 & $660^{\mathrm{a}}-510^{\mathrm{b}}$ & 1.170 \\
\hline$\quad$ Total & 55 & & & & & & & \\
\hline
\end{tabular}

a: Pederneiras; b: Luiz Antonio.

O comportamento silvicultural foi avaliado pelo crescimento médio dos caracteres $(\bar{x})$, incremento médio anual (IMA) e sobrevivência de plantas nos ensaios. Os dados foram obtidos do seguinte modo: 
a) Forma do Fuste (FF)

Os dados de FF foram obtidos por critérios subjetivos de notas, atribuindo-se:

Nota 1: tronco com defeito muito grave; tronco bifurcado; tronco muito tortuoso.

Nota 2: tronco com defeito grave; tronco bifurcado; tronco com tortuosidade acima da média.

Nota 3: tronco com defeito bastante visível; tronco sem bifurcação; tronco com tortuosidade média;

Nota 4: tronco com defeito pouco visível; tronco sem bifurcação; tronco com tortuosidade abaixo da média.

Nota 5: tronco sem defeito; tronco sem bifurcação; tronco tendendo a retidão ou reto.

Para a análise de variância (individual e conjunta) as notas em nível de plantas

foram transformadas para $\sqrt{x+0,5}$, sendo $x$ a nota dada a uma determinada árvore para o FF.

b) Diâmetro à Altura do Peito (DAP)

O DAP foi medido a $1,3 \mathrm{~m}$ de altura do tronco, com auxílio de uma suta dendrométrica.

c) Altura Total (ALT)

A ALT foi medida com um hipsômetro de Blume Leiss.

d) Volume Cilíndrico (VC)

O volume cilíndrico foi estimado para cada árvore pela equação:

$$
V c=\left[\frac{\pi(D A P / 100)^{2}}{4}\right] h t
$$

Onde: $h t$ altura total.

$\pi=3,141592654$. 


\section{e) Sobrevivência (SOB)}

A sobrevivência de plantas foi obtida em nível de sub-parcela pela contagem das árvores vivas. Para a análise de variância individual e conjunta, os dados individuais de SOB de plantas por sub-parcela foram transformados para logaritmo arco seno $-\sqrt{(\% S O B / 100)+0,5}$. A análise do caráter sobreviência foi realizado somente em nível de média de sub-parcelas.

\subsubsection{Isoenzimas}

Para a caracterização genética da espécie por isoenzimas, no ano de 1999, realizouse uma amostragem de tecidos foliares de 1.232 árvores $(39,1 \%$ ), no total dos dois ensaios. Em cada ensaio foram selecionadas as 30 melhores plantas de cada população, para o DAP (caráter medido com maior precisão do que a altura), utilizando-se o índice de seleção multi-efeito (Resende \& Higa, 1994), totalizando 180 árvores da amostra. Foram também selecionadas as 30 piores plantas, totalizando 180 árvores amostradas. $O$ restante das plantas $(1.232-360=872)$ foram amostradas aleatoriamente dentro dos ensaios procurando-se genotipar uma média de 20 plantas por progênie. $\mathrm{O}$ número de indivíduos amostrados por progênie variou de 9 a 31, com média de 24,1 para a população Campinas, 24,1 para Ibicatu e 19,8 para Vassununga (Tabela 14). As folhas foram coletadas e embaladas em sacos plásticos, devidamente identificadas por bloco, população, progênies e individuo na sub-parcela e levadas para o Laboratório de Reprodução e Genética de Espécies Arbóreas (LARGEA) do Departamento de Ciências Florestais da ESALQ/USP, para as análises de eletroforese de isoenzimas.

A eletroforese foi a horizontal, conduzida em meio suporte de gel de $2 / 3$ de amido de milho (penetrose 30) a 13\%, combinado com $1 / 3$ de amido de batata (Sigma). As "corridas" foram realizadas em geladeira com temperatura de $5^{\circ} \mathrm{C}$, mantendo-se a corrente constante de 35 miliamperes nos eletrodos para o tampão Tris Citrato (TC, pH 7,5 - Soltis et al., 1983) e de 30 miliamperes para o sistema Citrato Morfolina (CM, pH 6.1 - Clayton \& Tretiak, 1972). As enzimas foram extraídas de tecidos foliares de plantas 
Tabela 14. Amostragem para caracterização isoenzimática.

\begin{tabular}{|c|c|c|c|c|c|c|c|}
\hline Local & Pop. & Prog. & Infer. & Aleatório & Super. & & \\
\hline \multirow{4}{*}{ Luiz Antonio } & Campinas & 17 & 30 & 110 & 30 & & \\
\hline & Ibicatu & 16 & 30 & 100 & 30 & & \\
\hline & Vassununga & 17 & 30 & 100 & 30 & & \\
\hline & Total & 50 & 90 & 310 & 90 & & \\
\hline \multirow{5}{*}{ Pederneiras } & Campinas & 17 & 30 & 180 & 30 & & \\
\hline & Ibicatu & 16 & 30 & 166 & 30 & & \\
\hline & Vassununga & 22 & 30 & 216 & 30 & & \\
\hline & Total & $5 \overline{5}$ & 90 & 562 & 90 & & \\
\hline & & & & & & Total & Média/Prog \\
\hline \multirow{4}{*}{ Conjunta } & Campinas & 17 & 60 & 290 & 60 & 410 & 24,1 \\
\hline & Ibicatu & 16 & 60 & 266 & 60 & 386 & 24,1 \\
\hline & Vassununga & 22 & 60 & 316 & 60 & 436 & 19,8 \\
\hline & Total & 55 & $180^{-}$ & 872 & $180^{-}$ & 1.232 & \\
\hline
\end{tabular}

com 17 anos de idade, empregando-se aproximadamente $20 \mathrm{mg}$ de tecido de limbo foliar, $10 \mathrm{mg}$ de areia lavada, $7 \mathrm{mg}$ de Polivinil Pirrolidona (PVP 40), $7 \mathrm{mg}$ de Polivinil Pirrolidona (PVP-60) e 200 microlitros da solução de extração número 1 de Alfenas (1998), alterada pela ausência de Mercaptoetanol. As isoenzimas reveladas foram: Fosfatase Ácida (ACP-E.C. 3.1.3.2.), Alfa-Esterase ( $\alpha$-EST-E.C. 3.1.1.1), 6Fosfogluconato Desidrogenase (6PGDH-E.C. 1.1.1.44), Fosfoghucose Isomerase (PGIE.C. 5.3.1.9), Isocitrato Desidrogenase (IDH-E.C. 1.1.1.42), Malato Desidrogenase (MDH-E.C. 1.1.1.37), Peroxidase (PRX-E.C. 1.11.1.7), Xiquimato Desidrogenase (SKDH-E.C. 1.1.1.25) e Glucose 6 Fosfato Desidrogenase (G6PDH-E.C. 1.1.1.49.). As receitas de revelação das isoenzimas encontram-se em Alfenas (1998). Os sistemas ACP, PRX, IDH, G6PDH e SKDH foram revelados no tampão de eletrodo e gel TC e a PGI, MDH, $\alpha$-EST e 6 PGDH no tampão CM.

O padrão de segregação das isoezimas encontra-se nas Figuras 2 e 3. 

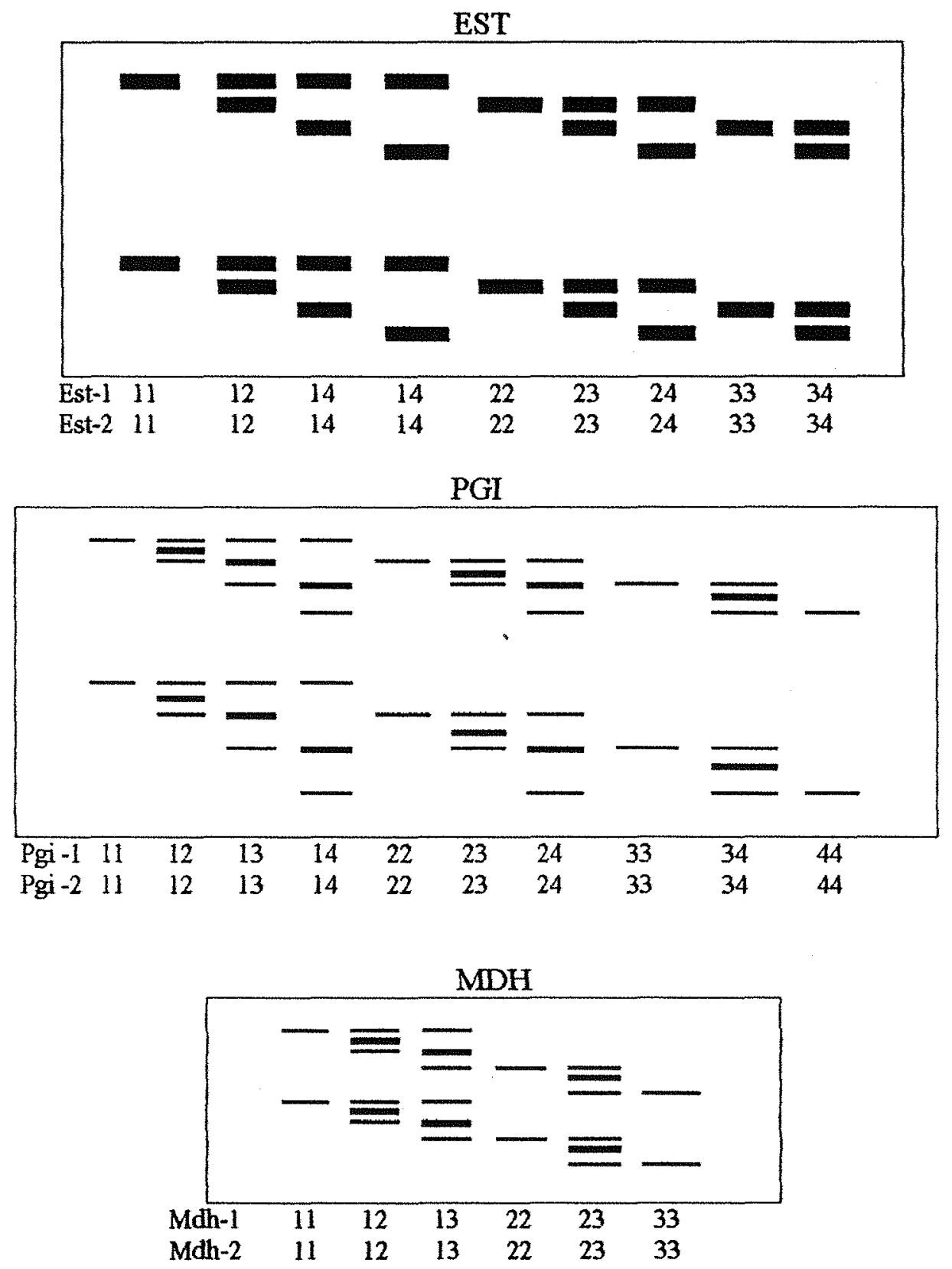

Figura 2 - Representação esquemática dos fenótipos observados nos zimogramas de $C$. legalis nos sistemas EST, PGI e MDH, juntamente com seus respectivos genótipos. 

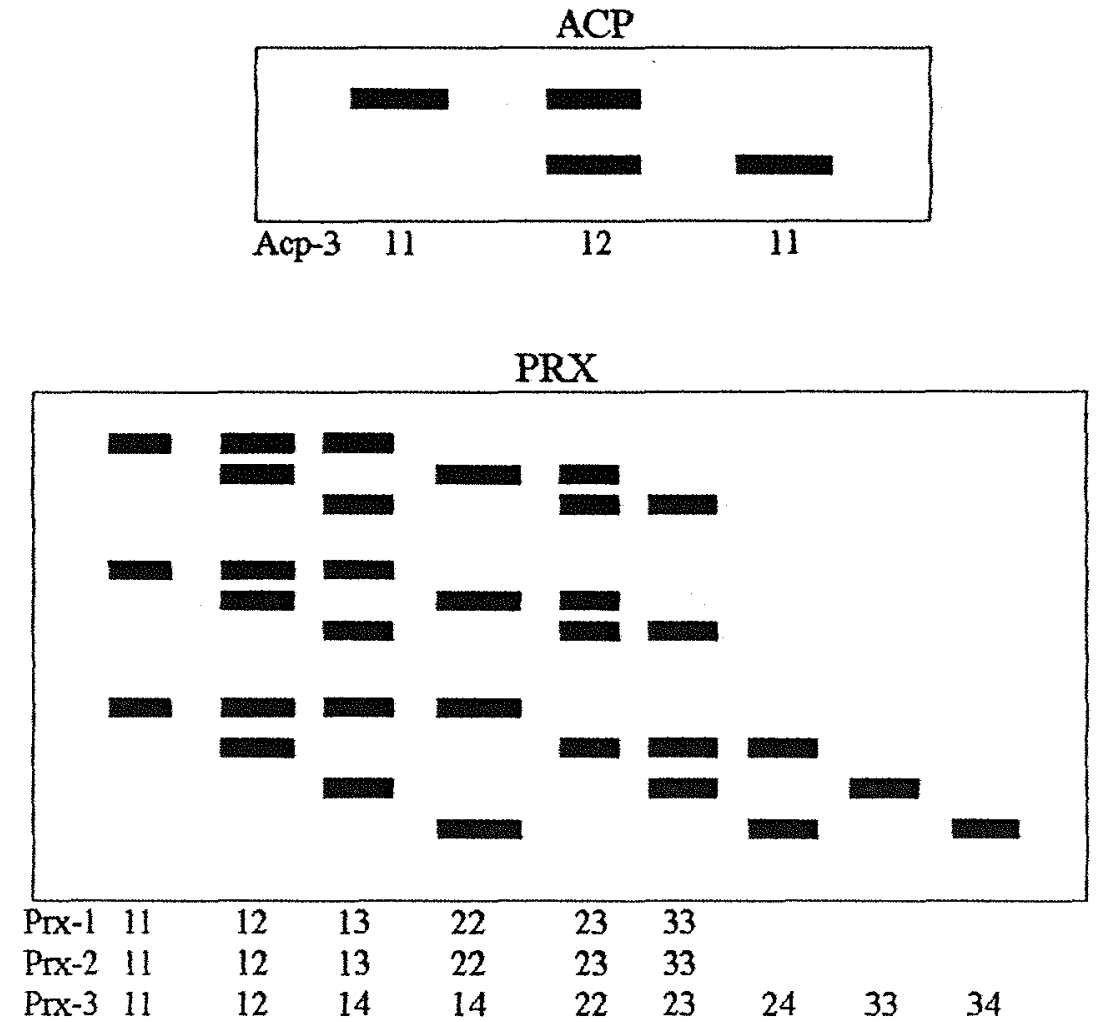

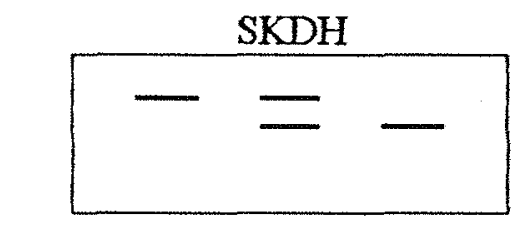

Skdh $-1 \quad 11 \quad 12 \quad 22$

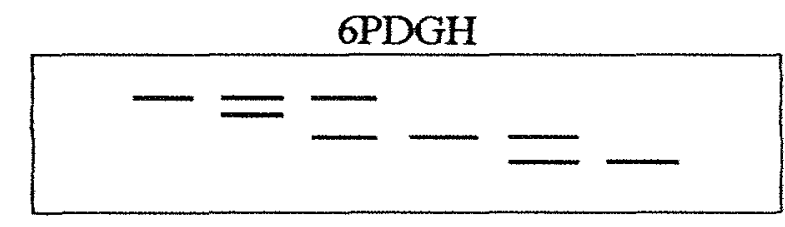

$\begin{array}{lllllll}6 \text { Pgdh-1 } & 11 & 12 & 13 & 22 & 23 & 33\end{array}$

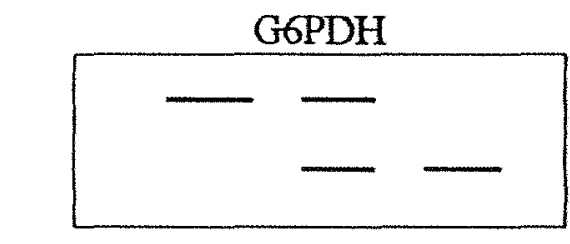

G6pdh-1 $11 \quad 12 \quad 22$

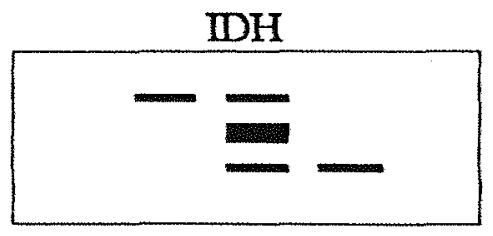

Idh $-2 \quad 11 \quad 12 \quad 22$

Figura 3 - Representação esquemática dos fenótipos observados nos zimogramas de $C$. legalis nos sistemas ACP, PRX, SKDH, 6PGDH, G6PDH e $\mathrm{IDH}$, juntamente com seus respectivos genótipos. 


\subsection{ANÁlISE ESTATÍSTICA}

\subsubsection{DADOS DE ISOENZIMAS}

\subsubsection{Sistema de Reprodução}

O sistema de reprodução das populações de $C$. legalis foi analisado com base no modelo de cruzamento misto de Ritland \& Jain (1981), através do programa "Multilocos MLTR" de Ritland (1997), uma versão mais atualizada do MLT de Ritland (1990). O programa estimou: 1) a taxa de cruzamento multilocos da população $\left(\hat{t}_{m}\right)$, pelo método de máxima verossimilhança (Expectation-Maximization - EM); 2) a taxa de cruzamento média unilocos da população $\left.\left(\hat{t}_{s}\right) ; 3\right)$ a taxa de cruzamento entre aparentados $\left(\hat{t}_{p}=\hat{t}_{m}\right.$ $\left.\left.\hat{t}_{s}\right) ; 4\right)$ as frequiências alélicas dos óvulos e do pólen ( $o$ e $p$ ), também pelo método de máxima verossimilhança; 5) a taxa de cruzamento individual por árvore materna; 6) a correlação de autofecundação entre dois filhos ou a proporção média de individuos de autofecundação dentro das progênies, ou ainda, a probabilidade que em uma progênie, onde existe um indivíduo gerado por autofecundação, encontre-se outro gerado da mesma forma $\left(\hat{r}_{S}\right)$ e; 7$)$ a correlação de paternidade de cruzamento entre dois irmãos, ou a proporção de irmãos completos entre irmãos de cruzamento dentro das progênies $\left(\hat{r}_{p}\right) . O$ modelo de cruzamento misto assume que as progênies resultam de uma mistura de cruzamentos aleatórios e autofecundação, cujas pressuposições básicas são: $i$ ) cada evento de reprodução é o resultado de cruzamentos aleatórios (com probabilidade $t$ ) ou de autofecundação (com probabilidade s); ii) a probabilidade de cruzamento é independente do genótipo materno; iii) que o conjunto de pólen é homogêneo para o cruzamento de todos os genótipos maternos; iv) que os alelos de diferentes locos segregam independentemente $\mathrm{e}, v$ ) que os locos avaliados não sofreram seleção ou mutação entre o evento reprodutivo e a análise dos indivíduos (Ritland \& Jain, 1981; Ritland, 1990; Ritland, 1997). Para estimar o erro padrão da média de $\hat{t}_{m}, \hat{t}_{s}, \hat{t}_{p}, \hat{r}_{s}, \hat{r}_{p}, o$ e $p, 0$ programa utilizou o procedimento de reamostragem do tipo bootstrap, onde a unidade de amostragem foram as plantas dentro das progênies para a taxa de cruzamento individual 
por árvore materna e progênies para taxa de cruzamento média das populaçðes. O número de reamostragem utilizades foi de 1.000 .

O teste de cruzamentos aleatórios foi realizado pelo teste de homogeneidade das frequêencias alélicas dos óvulos de do pólen e pelo teste de Equilíbrio de Hardy-Weinberg (EHW). O teste de homogeneidade foi realizado através da estimativa $\hat{G}_{S T}$ de Wright (1965), utilizando-a apenas como uma medida de divergência entre frequiências alélicas. Para testar a significância de $\hat{G}_{S T}$, para cada loco, aplicou-se o teste de qui-quadrado:

$$
\begin{aligned}
& \chi^{2}=2 n \hat{G}_{S T}(k-1), \\
& \mathrm{GL}=(k-1)(s-1),
\end{aligned}
$$

proposto por Workman \& Niswander (1970), onde: $n=$ é o número de gametas nos dois grupos (pólen e óvulos), $k=$ número de alelos e $s=$ número de grupos ( 2 - pólen e óvulo). O teste de aderência dos locos ao modelo de EHW, nas populações, foi realizado através do teste exato de Fisher, obtido a partir do programa BIOSYS-1 (Swofford \& Selander, 1989). O teste para separar efeitos do sistema de reprodução (autofecundação, cruzamento entre aparentados ou preferências) de fatores evolutivos (seleção, deriva genética, migração e mutação) foi o teste de Equilibrio de Endogamia de Wright (EEW). Este teste só foi realizado em locos que apresentaram desvios do EHW e no mínimo três alelos (número mínimo de alelos que permitam graus de liberdade suficientes para testar as hipóteses). O teste $\chi^{2}$ para verificar a aderência dos genótipos observados aos esperados pelo EEW, foi estimado conforme Vencovsky (1994):

$$
\chi^{2}=\Sigma\left(n_{o}-n_{e}\right)^{2} / n_{e}
$$

onde: $n_{o}=$ frequência genotípica observada; $n_{e}=$ frequêencia genotípica esperada pelo EEW. Esse teste considera o índice de fixação de Wright $(\hat{f})$ para as estimativas das freqüências genotípicas esperadas. Estas freqūêências foram obtidas segundo Weir (1996):

$$
\begin{aligned}
& P_{i i}=p_{i}^{2}+\hat{f} p_{i}\left(1-p_{i}\right) \\
& P_{i j}=2 p_{i} p_{j}(1-\hat{f})
\end{aligned}
$$


Sendo, $P_{i i}=$ freqüência genotípica esperada de homozigotos; $P_{i j}=$ freqüência genotípica esperada de heterozigotos, onde: $\hat{f}=$ índice de fixação de Wright; $p_{i}=$ freqüência do $i$ ésimo alelo. Os graus de liberdade foram dados por: $\mathrm{GL}=\left(\left[\mathrm{n}^{\circ}\right.\right.$ de classes genotípicas -1$]$ - [n ${ }^{\circ}$ de alelos - 1] - 1), sendo um grau de liberdade perdido devido ao $\hat{f}$ (Vencovsky, 1994). Como pode ser observado, devido à computação dos graus de liberdade, o teste só pode ser aplicado em locos que possuam no mínimo 3 alelos. $O \hat{f}$ foi estimado em nível de locos e média entre locos, de acordo com as expressões 75 e 76.

\subsubsection{Estrutura Genética}

A estrutura genética ou a distribuição da variabilidade genética entre e dentro das populações de $C$. legalis foi caracterizada, para as isoenzimas, pelas freqüências alélicas e pela análise de variância das freqüências gênicas.

a) Frequiências alélicas

As freqüências alélicas foram estimadas para as populações pela expressão:

$$
\hat{p}_{i j k}=\frac{n_{i j k}}{n_{. j k}}
$$

Onde: $\hat{p}_{i j k}=$ freqüência do alelo $k$, no loco $j$, na população $i$;

$n_{j j k}=$ número de ocorrência do alelo $k$, no loco $j$, na população $i$;

$n_{. j k}=$ número total de alelos amostrados, no loco $j$, na população $i$.

\section{b) Análise da Variância de Freqüências Alélicas}

\section{b1) Análise Individual das Populações}

A análise da variância das frequêencias alélicas foi realizada com base no modelo aleatório hierárquico desbalanceado (Weir, 1996). Inicialmente, a análise foi realizada $\mathrm{em}$ nível de alelo e, posteriormente, conjunta para todos os alelos de cada loco. Assim, de acordo com Weir (1996), a variável $x_{i j k}$ corresponde ao alelo $k$, no indivíduo $j$, na progênie $i$, portanto, quando $x_{i j k}$ estava presente, recebeu o valor 1,0 e quando estava 
ausente recebeu o valor zero. $O$ modelo estatístico para a análise hierárquica de indivíduos dentro de progênies foi:

$$
Y_{i j k}=m+f_{i}+b_{j(i)}+g_{k(i j)}
$$

onde: $Y_{b j k}=$ freqüência do alelo $k$, dentro do indivíduo $j$, dentro da progênie $i$; $m=$ média geral das freqüências alélicas;

$f_{i}=$ efeito da progênie $i, \operatorname{com} i=1,2, \ldots, a$,

$b_{j(i)}=$ efeito do indivíduo $j$, dentro da progênie $i$, com $j=1,2, \ldots, b_{i}$;

$g_{k(i j)}=$ efeito do alelo $k$, dentro do indivíduo $j$, dentro da progênie $i$, com $k=$ $1,2, \ldots, \quad n_{i j}$.

As estimativas dos componentes da variância foram obtidas da Tabela 15, a partir da decomposição das esperanças dos quadrados médios:

Tabela 15. Esquema da análise da variância de freqüências alélicas no modelo hierárquico desbalanceado para indivíduos dentro de progênies.

\begin{tabular}{lccll}
\hline \multicolumn{1}{c}{ FV } & GL & $S Q$ & $Q M$ & \multicolumn{1}{c}{$E(Q M)$} \\
\hline Progênies & $a-1$ & $S Q F$ & $Q M_{F}$ & $\hat{\sigma}_{G}^{2}+2 \hat{\sigma}_{I}^{2}+k_{l} \hat{\sigma}_{F}^{2}$ \\
Indivíduos/Progênies & $\sum_{i=1}^{a} b_{j}-a$ & $S Q I$ & $Q M_{I}$ & $\hat{\sigma}_{G}^{2}+2 \hat{\sigma}_{I}^{2}$ \\
Genes/Individuos & $\mathbf{n}_{. .}-\sum_{i=1}^{a} b_{j}$ & $S Q_{G}$ & $Q M_{G}$ & $\hat{\sigma}_{G}^{2}$ \\
& $n_{\ldots-.}-1$ & & & \\
\hline Total & $S Q_{T}$ & & \\
\hline
\end{tabular}

$$
\begin{aligned}
& \hat{\sigma}_{G}^{2}=Q M_{G} \\
& \hat{\sigma}_{I}^{2}=\frac{Q M_{I}-Q M_{O}}{2} \\
& \hat{\sigma}_{F}^{2}=\frac{Q M_{F}-Q M_{I}}{k_{1}}
\end{aligned}
$$


Onde: $k_{1}=$ correspondem ao coeficiente das variâncias entre progênies $\left(\hat{\sigma}_{F}^{2}\right)$ no modelo hierárquico desbalanceado:

$$
k_{1}=\frac{1}{\sum_{i} b_{i}-a}\left[n_{t_{-}}-\sum_{i} \sum_{j}\left(\frac{n_{i j .}^{2}}{n_{i-}}\right)\right]
$$

O significado genético dos componentes da variância são definidos abaixo:

$$
\begin{aligned}
\sigma_{F}^{2} & =p(I-p)\left(\theta_{F}\right) \\
\sigma_{I}^{2} & =p(I-p)\left(F-\theta_{F}\right) \\
\sigma_{O}^{2} & =p(l-p)(1-F) \\
\sigma_{T}^{2} & =\sigma_{F}^{2}+\sigma_{I}^{2}+\sigma_{G}^{2}=p(l-p)
\end{aligned}
$$

Onde: $p=$ freqüência de um alelo em um determinado loco; $\hat{\theta}_{F}=$ coeficiente de parentesco ou coancestralidade média entre duas plantas dentro das progênies ou divergência genética entre progênies, ou ainda, correlação das freqüências alélicas de diferentes plantas dentro das progênies; $\hat{F}$ = correlação entre alelos, dentro de indivíduos de diferentes progênies; $\hat{f}=$ índice de fixação ou correlação entre alelos dentro de indivíduos de uma mesma progênie. As estimativas do coeficiente de coancestralidade e dos índices de fixação podem ser obtidas dos componentes da variância por:

$$
\begin{aligned}
& \hat{\theta}_{F}=\frac{\hat{\sigma}_{F}^{2}}{\hat{\sigma}_{T}^{2}} \\
& \hat{F}=1-\frac{\hat{\sigma}_{G}^{2}}{\hat{\sigma}_{T}^{2}}=\frac{\hat{\sigma}_{F}^{2}+\hat{\sigma}_{I}^{2}}{\hat{\sigma}_{T}^{2}} \\
& \hat{f}=\frac{\left(\hat{F}-\hat{\theta}_{F}\right)}{\left(1-\hat{\theta}_{F}\right)}
\end{aligned}
$$

As estimativas médias entre locos para os parâmetros $\hat{\theta}_{F}, \hat{F}$ e $\hat{f}$, foram obtidas pela média ponderada dos quadrados médios, da seguinte forma:

$$
Q M_{F}=\Sigma S Q_{F} / \Sigma G L_{F}
$$




$$
\begin{aligned}
& Q M_{I}=\Sigma S Q_{I} / \Sigma G L_{I} \\
& Q M_{G}=\Sigma S Q_{G} / \Sigma G L_{G}
\end{aligned}
$$

\section{b2) Análise da Variância Conjunta das Populações}

Para análise da variância das freqüências alélicas de indivíduos, dentro de progênies, dentro de populações, utilizou-se o modelo estatístico:

$$
Y_{l j k k}=m+p_{l}+f_{i(l)}+b_{j(i l)}+g_{k(i j)}
$$

onde: $Y_{l i j k}=$ frequiência do alelo $k$, dentro do indivíduo $j$, dentro da progênie $i$, dentro da população $l$;

$\boldsymbol{m}=$ média geral das frequuências alélicas;

$p_{l}=$ efeito da população $l, \operatorname{com} l=1,2, \ldots, a$,

$f_{i(l)}=$ efeito da progênie $i$, dentro da população $l, \operatorname{com} i=1,2, \ldots, b_{l}$;

$b_{j(i l)}=$ efeito do indivíduo $j$, dentro da progênie $i$, dentro da população $l, \operatorname{com} j=$ $1, \quad 2, \ldots, c_{i l} ;$

$g_{k(j i l)}=$ efeito do alelo $k$, dentro do indivíduo $j$, dentro da progênie $i$, dentro da população $l, \operatorname{com} k=1,2, \ldots, n_{j j k}$.

As estimativas dos componentes da variância para a hierarquia de genes/individuos/progênies/populações foi obtida da Tabela 16, a partir da decomposição das esperanças dos quadrados médios:

$$
\begin{aligned}
& \hat{\sigma}_{\sigma}^{2}=Q M_{G} \\
& \hat{\sigma}_{I}^{2}=\frac{Q M_{I}-Q M_{G}}{2} \\
& \hat{\sigma}_{F}^{2}=\frac{Q M_{F}-Q M_{I}}{k_{1}} \\
& \hat{\sigma}_{P}^{2}=\frac{Q M_{P}-\left(Q M_{I}-k_{2} \hat{\sigma}_{F}^{2}\right)}{k_{3}}
\end{aligned}
$$


onde: $k_{1}, k_{2}$ e $k_{3}=$ correspondem aos coeficientes das variâncias entre progênies $\left(\hat{\sigma}_{F}^{2}\right) \mathrm{e}$ entre populaçōes $\left(\hat{\sigma}_{P}^{2}\right)$, no modelo hierárquico desbalanceado (Tabela 16), obtidos da seguinte forma:

$$
\begin{aligned}
& k_{1}=\frac{1}{\sum_{i} b_{i}-a}\left[n_{t . .}-\sum_{i} \sum_{i}\left(\frac{n_{t y}^{2}}{n_{i . .}}\right)\right] \\
& k_{2}=\frac{1}{a-1}\left[\sum_{i} \sum_{j}\left(\frac{n_{i j .}^{2}}{n_{i . .}}\right)-\frac{n_{i j .}^{2}}{n_{i .}}\right] \\
& k_{3}=\frac{1}{a-1}\left[\sum_{i} n_{t . .}-\frac{\sum_{i} n_{i}^{2}}{\sum_{i} n_{i}}\right]
\end{aligned}
$$

Tabela 16. A análise da variância de freqüências alélicas no modelo hierárquico desbalanceado para progênies dentro de populações.

\begin{tabular}{lccll}
\hline \multicolumn{1}{c}{ FV } & GL & $S Q$ & $Q M$ & \multicolumn{1}{c}{$E(Q M)$} \\
\hline Populações & $a-1$ & $S Q_{P}$ & $Q M_{P}$ & $\hat{\sigma}_{G}^{2}+2 \hat{\sigma}_{I}^{2}+k_{2} \hat{\sigma}_{F}^{2}+k_{3} \hat{\sigma}_{P}^{2}$ \\
Progênies/Populações & $\sum_{i} b_{1}-a$ & $S Q_{F}$ & $Q M_{F}$ & $\hat{\sigma}_{G}^{2}+2 \hat{\sigma}_{I}^{2}+k_{l} \hat{\sigma}_{F}^{2}$ \\
Individuos/Progênies & $\sum_{l} \sum_{i} c_{l i}-\sum_{l} b_{l}$ & $S Q_{I}$ & $Q M_{I}$ & $\hat{\sigma}_{G}^{2}+2 \hat{\sigma}_{I}^{2}$ \\
Genes/Indivíduos & $n-\sum_{l} \sum_{i} c_{l i}$ & $S Q_{G}$ & $Q M_{G}$ & $\hat{\sigma}_{G}^{2}$ \\
\hline Total & $n \ldots-1$ & $S Q_{T}$ & \\
\hline
\end{tabular}

O significado genético dos componentes da variância são definidos abaixo:

$$
\begin{aligned}
\sigma_{P}^{2} & =p(1-p)\left(\theta_{P}\right) \\
\sigma_{F}^{2} & =p(1-p)\left(\theta_{F}-\theta_{P}\right) \\
\sigma_{I}^{2} & =p(1-p)\left(F-\theta_{F}\right) \\
\sigma_{G}^{2} & =p(1-p)(1-F)
\end{aligned}
$$




$$
\sigma_{T}^{2}=\sigma_{P}^{2}+\sigma_{F}^{2}+\sigma_{I}^{2}+\sigma_{G}^{2}=p(1-p)
$$

onde: $p=$ frequência de um alelo em um determinado loco; $\hat{\theta}_{P}=$ coeficiente de parentesco ou coancestralidade de indivíduos dentro de populações ou divergência genética entre populações ou ainda, correlação entre freqüências alélicas de individuos dentro de populações; $\hat{\theta}_{F}=$ coeficiente de parentesco ou coancestralidade das plantas dentro das progênies, ou correlação das frequiências alélicas de diferentes plantas dentro das progênies; $\hat{F}=$ correlação entre alelos dentro de indivíduos de diferentes populações. As estimativas dos coeficientes de coancestralidades e dos índices de fixação podem ser obtidas dos componentes da variância por:

$$
\begin{aligned}
& \hat{\theta}_{P}=\frac{\hat{\sigma}_{P}^{2}}{\hat{\sigma}_{T}^{2}} \\
& \hat{\theta}_{F}=\frac{\hat{\sigma}_{F}^{2}+\hat{\sigma}_{P}^{2}}{\hat{\sigma}_{T}^{2}}=\frac{\hat{\sigma}_{F}^{2}}{\hat{\sigma}_{P}^{2}}+\hat{\theta}_{P} \\
& \hat{F}=1-\frac{\hat{\sigma}_{Q}^{2}}{\hat{\sigma}_{T}^{2}} \\
& \hat{f}=\frac{\left(\hat{F}-\hat{\theta}_{P}\right)}{\left(1-\hat{\theta}_{P}\right)}
\end{aligned}
$$

onde: $\hat{\theta}_{F}=$ coeficiente de parentesco das plantas dentro das progênies ou correlação das frequiências alélicas de diferentes plantas dentro das progênies; parâmetros que correspondem a $1 / 8$ em progênies de meios irmãos, $1 / 4$ em irmão germanos e $1 / 2$ em progênies de autofecundação. Valores desta estimativa em progênies de polinização aberta, superiores a 0,125 , indicam que as progênies não são constituídas exclusivamente por meios irmãos e/ou a presença de endogamia dentro das progênies. Este parâmetro é de grande valor em trabalhos de melhoramento, visto que pode auxiliar no conhecimento da estrutura interna das progênies. $\hat{f}=$ correlação entre alelos dentro de indivíduos, dentro de diferentes progênies. As estimativas médias entre locos para os parâmetros $\hat{\theta}_{P}, \hat{\theta}_{F}$, $\hat{F}$, e $\hat{f}$ foram obtidas pela média ponderada dos quadrados médios, da seguinte forma: 


$$
\begin{aligned}
& Q M_{P}=\Sigma S Q_{P} / \Sigma G L_{P} \\
& Q M_{F}=\Sigma S Q_{P} / \Sigma G L_{F} \\
& Q M_{I}=\Sigma S Q_{I} / \Sigma G L_{I} \\
& Q M_{G}=\Sigma S Q_{G} / \Sigma G L_{G}
\end{aligned}
$$

Para verificar se as estimativas médias de $\hat{\theta}_{p}, \hat{\theta}_{F}, \hat{F}$, e $\hat{f}$ eram diferentes de zero, estimaram-se o intervalos de confiança a $95 \%$ de probabilidade pelo método de reamostragem bootstrap. Utilizou-se 10.000 repetições sobre os locos. As análises da variâncias descritas acima e os bootstraps foram obtidos através do programa GDA de Lewis \& Zaykin (1999).

\subsection{3 Variabilidade Genética Intrapopulacional}

A diversidade genética intrapopulacional foi analisada pela heterozigosidade observada, diversidade gênica esperada segundo o equilibrio de Hardy-Weinberg, número médio de alelos por loco, porcentagem de locos polimórficos e índice de fixação de Wright, estimativas obtidas a partir do programa BIOSYS-1 (Swofford \& Selander, 1989).

a) Heterozigosidade Média Observada

A heterozigosidade observada $\left(\hat{H}_{\circ}\right)$ para cada loco foi obtida por:

$$
\hat{H}_{\circ}=1-\sum P_{i i}
$$

onde: $P_{i i}=$ freqüência dos genótipos homozigotos.

b) Diversidade Gênica Média Esperada

A diversidade gênica esperada $\left(\hat{H}_{e}\right)$ viesada para cada loco foi obtida segundo Nei

(1978) por:

$$
\hat{H}_{e}=\left(\frac{n}{n-1}\right)\left(1-\sum p_{i}^{2}\right)
$$

onde: $p_{i}=$ freqüuência alélica estimada do $i$-ésimo alelo. 
A estimativa média sobre os locos de $\hat{H}_{a}$ e $\hat{H}_{\varepsilon}$ foi obtida pela média aritmética entre todos os locos analisados (monomórficos mais polimórficos).

\section{c) Porcentagem de Locos Polimórficos}

A porcentagem de locos polimórficos $(\hat{P})$ foi estimada pela média aritmética do número total de alelos pelo número de locos, sendo que um loco foi considerado polimórfico quando a freqūência do alelo mais comum não ultrapassava $95 \%$.

\section{d) Número Médio de Alelos Por Locos}

O número médio de alelos por locos $(\hat{A})$ foi obtido pela divisão do número total de alelos pelo número total de locos.

\section{e) Índice de Fixação de Wright}

O índice de fixação de Wright $(\hat{f})$ não viesado foi estimado segundo Weir (1996) em nivel de locos e média entre locos, pelas expressões:

$$
\begin{aligned}
& \hat{f}=\frac{\left(\hat{H}_{e}-\hat{H}_{o}\right)+\frac{1}{2 n} \hat{H}_{o}}{\hat{H}_{e}-\frac{1}{2 n} \hat{H}_{o}} \text { (nível de loco); } \\
& \hat{f}=\frac{\left.\left(\sum \hat{H}_{e}-\sum \hat{H}_{o}\right)+\frac{1}{2 n} \sum \hat{H}_{o}\right)}{\sum \hat{H}_{e}-\frac{1}{2 n} \sum \hat{H}_{o}} \text { (média entre locos) }
\end{aligned}
$$

O teste para verificar se os valores de $\hat{f}$ em nível de loco era estatisticamente diferente de zero, foi:

$$
\begin{aligned}
& \chi^{2}=n \hat{f}^{2}(k-1), \\
& \mathrm{GL}=[k(k-1)] / 2,
\end{aligned}
$$

onde: $\hat{f}=$ índice de fixação, $n=$ número total de indivíduos amostrados e $\mathrm{k}$ é o número de alelos ( $\mathrm{Li}$ \& Horvitz, 1953). Para verificar se os valores médios de $\hat{f}$, eram diferentes de zero, estimou-se o intervalo de confiança a $95 \%$ de probabilidade, pelo método de reamostragem bootstrap, utilizando-se 10.000 reamostragens sobre os locos, através do programa GDA de Lewis \& Zaykin (1999). 


\subsubsection{Caracteres Quantitativos}

\subsubsection{Análise da Variância Individual}

A análise da variância individual para os locais foi realizada conforme o modelo estatístico:

$$
Y_{i j k}=m+t_{i}+b_{j}+(t b)_{i j}+t_{k(i)}^{\prime}+e_{i j k}
$$

onde:

$Y_{i j k}=$ média da progênie $k$, na população $i$, no bloco $j$;

$\boldsymbol{m}=$ média geral do caráter nas populaçōes;

$t_{i}=$ efeito aleatório da populaçãa $i(i=1,2, \ldots, h)$;

$b_{j}=$ efeito aleatório do bloco $j(j=1,2, \ldots, J)$;

$(t b)_{i j}=$ erro experimental em nível de parcelas;

$t^{\prime}{ }_{k(i)}=$ efeito aleatório da progênie $k(k=1,2, \ldots, K)$, dentro da população $i(i=1$, $2, \ldots, I)$

$e_{i j k}=$ efeito do erro em nível de sub-parcela.

A variância fenotípica dentro das sub-parcelas $\left(\hat{\sigma}_{d}^{2}\right)$ foi obtida pela média ponderada dos quadrados médios dentro de sub-parcela, para cada população separadamente e em conjunto. A estrutura da análise individual para locais encontra-se na Tabela 17.

O teste $\mathrm{F}$ estimado para o efeito de populações não foi exato, portanto os graus de liberdade foram dados pelas estimativas de Satterthwaite (1946).

$$
\begin{aligned}
& n_{1}=\frac{\left(Q_{2}+Q_{9}\right)^{2}}{\frac{\left(Q_{2}\right)^{2}}{I-1}+\frac{\left(Q_{9}\right)^{2}}{I\left[\sum\left(K_{i}-1\right)\right](J-1)}} \\
& n_{2}=\frac{\left(Q_{3}+Q_{5}\right)^{2}}{\frac{\left(Q_{3}\right)^{2}}{(I-1)(J-1)}+\frac{\left(Q_{5}\right)^{2}}{I\left[\sum\left(K_{i}-1\right)\right]}}
\end{aligned}
$$


Tabela 17. Quadro da análise da variância com as fontes de variação (FV), os graus de liberdade (GL), esperanças dos quadrados médios [E(QM)] e quadrados médios testadores de $\mathrm{F}$.

\begin{tabular}{|c|c|c|c|c|}
\hline FV & GL & $\mathrm{QM}$ & $\mathrm{E}(\mathrm{QM})$ & $F$ \\
\hline Blocos & $J-1$ & $Q_{I}$ & $\frac{\hat{\sigma}_{d}^{2}}{\bar{n}}+\hat{\sigma}_{e b}^{2}+K \hat{\sigma}_{e a}^{2}+I K \hat{\sigma}_{b}^{2}$ & $\mathrm{Q}_{1} / \mathrm{Q}_{3}$ \\
\hline Populações & $1-1$ & $Q_{2}$ & $\frac{\hat{\sigma}_{d}^{2}}{\bar{n}}+\hat{\sigma}_{a b}^{2}+K \hat{\sigma}_{* a}^{2}+J \hat{\sigma}_{F / P}^{2}+J K \hat{\sigma}_{P}^{2}$ & $\frac{Q_{2}+Q_{9}}{Q_{3}+Q_{5}}$ \\
\hline Erro (a) & $(1-1)(J-1)$ & $Q_{3}$ & $\frac{\hat{\sigma}_{d}^{2}}{\bar{n}}+\hat{\sigma}_{e b}^{2}+K \hat{\sigma}_{p a b}^{2}$ & \\
\hline Parcelas & $I J=I$ & $Q_{4}$ & - & \\
\hline Prog./Pop. & $I \Sigma\left(K_{i}-1\right)$ & $Q_{s}$ & $\frac{\hat{\sigma}_{d}^{2}}{\bar{n}}+\hat{\sigma}_{\cdot b}^{2}+J \hat{\sigma}_{F / P}^{2}$ & $\mathrm{Q}_{3} / \mathrm{Q}_{3}$ \\
\hline Prog./Pop. 1 & $K_{1}-1$ & $Q_{6}$ & $\frac{\hat{\sigma}_{d}^{2}}{\bar{n}}+\hat{\sigma}_{\cdot b}^{2}+J \hat{\sigma}_{p|P|}^{2}$ & $\mathrm{Q}_{0} / \mathrm{Q}_{\theta}$ \\
\hline Prog./Pop. 2 & $K_{2}-1$ & $Q_{7}$ & $\frac{\hat{\sigma}_{d}^{2}}{\bar{n}}+\hat{\sigma}_{o b}^{2}+J \hat{\sigma}_{P / P 2}^{2}$ & $\mathrm{Q}_{7} / \mathrm{Q}_{0}$ \\
\hline Prog./Pop. 3 & $K_{3}-1$ & $Q_{8}$ & $\frac{\hat{\sigma}_{d}^{2}}{\bar{n}}+\hat{\sigma}_{\cdot b}^{2}+J \hat{\sigma}_{P / P 3}^{2}$ & $\mathrm{Q}_{8} / \mathrm{Q}_{3}$ \\
\hline Erro (b) & $I \Sigma\left(K_{i}-1\right)(J-1)$ & $Q_{9}$ & $\frac{\hat{\sigma}_{d}^{2}}{\bar{n}}+\hat{\sigma}_{e b}^{2}$ & \\
\hline Dentro F/P & $J I \Sigma K_{i}(\bar{n}-1)$ & $Q_{10}$ & $\hat{\sigma}_{d}^{2}$ & \\
\hline Total & $\left(J I K_{i}\right)-1$ & $Q_{I I}$ & & \\
\hline
\end{tabular}

Sendo, $J=$ número de blocos; $I=$ número de populações; $K=$ número de progênies por população, e; $n$ = média harmônica do número de plantas por sub-parcela. 


\section{a) Estimativa dos Componentes da Variância}

Os componentes da variância foram obtidos pela decomposição dos quadrados médios da análise da variância individual, da seguinte forma:

Variância entre blocos:

$$
\hat{\sigma}_{b}^{2}=\frac{Q_{1}-Q_{3}}{I K} ;
$$

Var. genética entre populações: $\quad \hat{\sigma}_{p}^{2}=\left(\frac{1}{J K}\right)\left(\frac{Q_{2}+Q_{9}}{Q_{3}+Q_{s}}\right)$;

Var. ambiental entre parcelas:

$$
\hat{\sigma}_{e a}^{2}=\frac{Q_{3}-Q_{9}}{K}
$$

Var. genética entre progênies/populações: $\quad \hat{\sigma}_{F / P}^{2}=\frac{Q_{5}-Q_{9}}{J}$;

Var. genética entre progênies/população 1: $\quad \hat{\sigma}_{F / P 1}^{2}=\frac{Q_{6}-Q_{9}}{J}$;

Var. genética entre progênies/população 2: $\hat{\sigma}_{F / P 2}^{2}=\frac{Q_{7}-Q_{9}}{J}$;

Var. genética entre progênies/população 3: $\quad \hat{\sigma}_{F / P 3}^{2}=\frac{Q_{8}-Q_{9}}{J}$;

Var. ambiental entre sub-parcelas:

$$
\hat{\sigma}_{e b}^{2}=Q_{9}-\left(\frac{Q_{10}}{\bar{n}}\right) ;
$$

Var. fenotípica dentro de progênies/populações: $\hat{\sigma}_{d}^{2}=Q_{10}$.

\section{b) Estimativa de Parâmetros Genéticos}

A herança dos caracteres foi avaliáda pelos coeficientes de herdabilidade: entre progênies $\left(\hat{h}_{f}^{2}\right)$, individual dentro de progênies $\left(\hat{h}_{d}^{2}\right)$, entre sub-parcelas dentro de parcelas $\left(\hat{h}_{p}^{2}\right)$, dentro de blocos $\left(\hat{h}_{b}^{2}\right)$ e indivíduos nos blocos $\left(\hat{h}_{t}^{2}\right)$, estimados de acordo com Resende \& Higa (1994b): 
Coef. de herd. entre progênies $\left(\hat{h}_{f}^{2}\right): \hat{h}_{f}^{2}=\frac{\left\{\frac{[1+(\bar{n} J-1) r]}{\bar{n} J}\right\} \sigma_{d}^{2}}{\hat{\sigma}_{f l P_{j}}^{2}+\frac{\hat{\sigma}_{a b}^{2}}{J}+\frac{\hat{\sigma}_{d}^{2}}{\bar{n} J}}$

Coef. de herd. dentro de progênies $\left(\hat{h}_{d}^{2}\right): \hat{h}_{d}^{2}=\frac{(1-r) \hat{\sigma}_{A}^{2}}{\hat{\sigma}_{d}^{2}}$

Coef. de herd. entre sub-parcelas $\left(\hat{h}_{p}^{2}\right): \quad \hat{h}_{p}^{2}=\frac{\left(\frac{1-r}{\bar{n}}\right) \hat{\sigma}_{A}^{2}}{\hat{\sigma}_{o b}^{2}+\frac{\hat{\sigma}_{d}^{2}}{\bar{n}}}$

Coef. de herd. dentro de blocos $\left(\hat{h}_{b}^{2}\right)$ :

$$
\hat{h}_{b}^{2}=\frac{\frac{1-r}{\bar{n} I} \hat{\sigma}_{A}^{2}}{\hat{\sigma}_{b}^{2}+\frac{\hat{\sigma}_{e b}^{2}}{I}+\frac{\hat{\sigma}_{d}^{2}}{\bar{n} I}}
$$

Coef. de herd. em nivel de plantas $\left(\hat{h}_{i}^{2}\right): \quad \hat{h}_{t}^{2}=\frac{\hat{\sigma}_{A}^{2}}{\hat{\sigma}_{f}^{2}+\hat{\sigma}_{c b}^{2}+\hat{\sigma}_{d}^{2}}$

Os índices $J, K, I, \bar{n}$ e as variâncias já foram previamente definidos; $r$ é 0 coeficiente de parentesco. Para o caráter sobrevivência de plantas, só foi estimada a herdabilidade em nível de médias de progênies, devido à sobrevivência ser medida para o total das sub-parcelas e não em nível individual.

A variabilidade genética dentro das populações foi analisada pelos coeficientes de variação genética entre progênies $\left(C \hat{V}_{g}\right)$ e fenotípico dentro de progênies $\left(C V_{d}\right)$ estimados de acordo com Kageyama (1980):

$$
\begin{aligned}
& C \hat{V}_{8}=\frac{\sqrt{\hat{\sigma}_{F / P_{f}}^{2}}}{\bar{x}} \times 100 ; \\
& C \hat{V}_{d}=\frac{\sqrt{\hat{\sigma}_{d}^{2}}}{\bar{x}} \times 100 .
\end{aligned}
$$




\subsubsection{Análise da Variância Conjunta}

A análise da variância conjunta para locais foi realizada considerando-se apenas as progênies comuns aos dois locais de ensaio ( 50 progênies). $O$ modelo estatístico utilizado na análise conjunta dos experimentos, considerando-se locais como de efeito fixo e populações e progênies como efeito aleatório foi:

$$
Y_{i j k l}=m+t_{i}+l_{l}+b_{j n}+(t l)_{i l}+(t b)_{i j(l)}+t^{i} k(i)+\left(t^{\prime} l\right)_{k l(i)}+e_{i j k d}
$$

onde:

$Y_{i j k l}=$ valor da progênie $k$, no bloco $j$, na população $i$, no local $l$;

$m=$ média geral do caractere nas populações;

$t_{i}=$ efeito aleatório da população $i(i=1,2, \ldots, l)$;

$l_{l}=$ efeito fixo do local $l(l=1,2, \ldots ., L)$;

$b_{j / l}=$ efeito aleatório do bloco $j(j=1,2, \ldots, J)$, dentro do local $l$;

$\left(t l_{i l}=\right.$ efeito da interação da população $i$ no local $l$;

$(t b)_{i k(l)}=$ erro experimental em nível de parcelas;

$t^{\prime}{ }_{k(i)}=$ efeito aleatório da progênie $k\left(k=1,2, \ldots, K_{i}\right)$, dentro da populaçãa $i$;

$\left(t^{\prime}\right)_{k I(i)}$ - efeito da interação de progênies/população por locais;

$e_{i j d d}=$ efeito do erro em nível de sub-parcela.

O esquema da análise da variância conjunta para locais encontra-se na Tabela 18.

Sendo nesta: $L=$ número de locais; $J=$ número de blocos; $I=$ número de populações; $K=$ número de progênies por população $\mathrm{e} ; \bar{n}=$ média harmônica do número de plantas por sub-parcela; $\hat{\Phi}_{L}=\Sigma L^{2} /(L-I)$, não representando, portanto, um parâmetro populacional. 


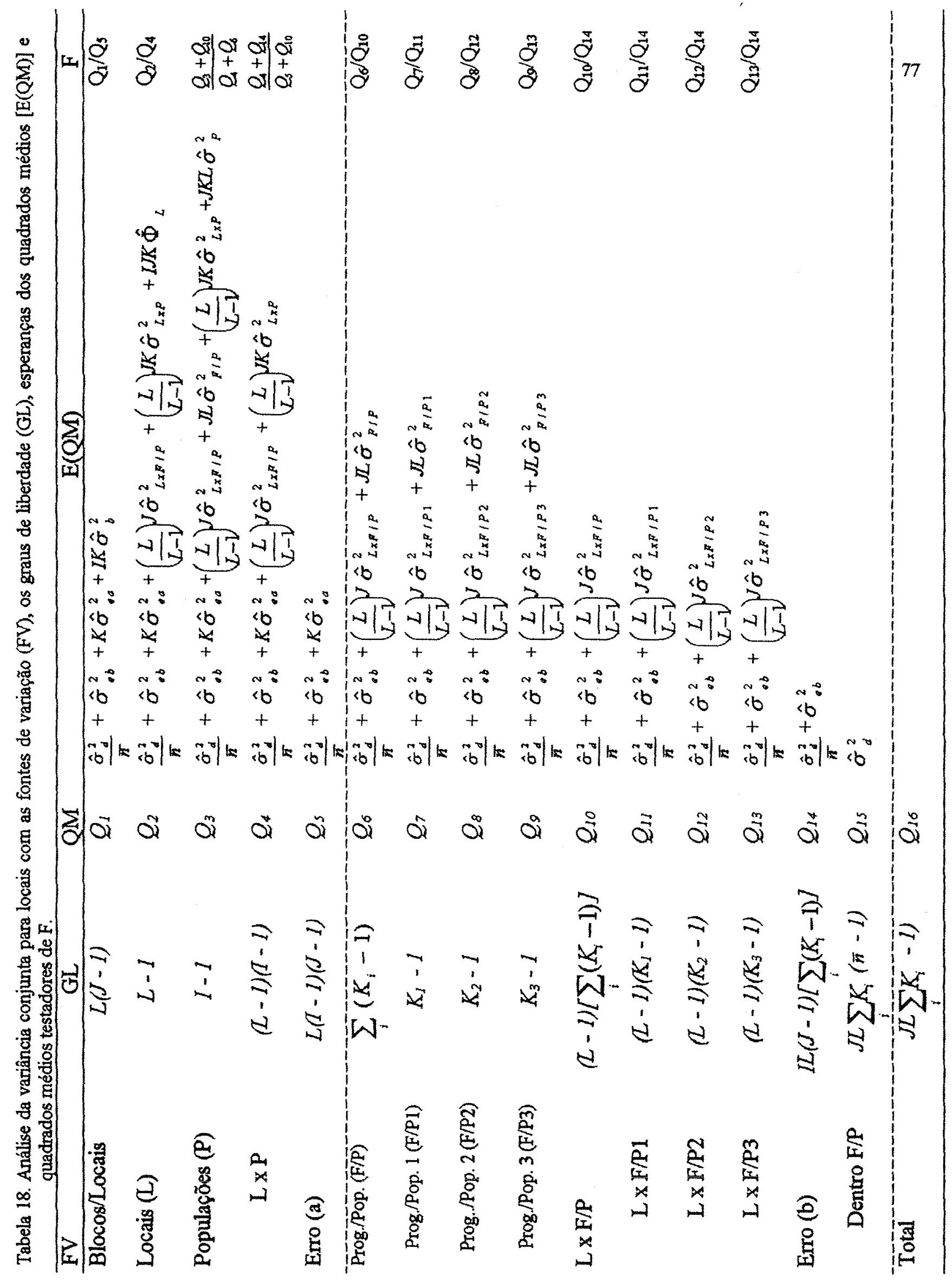




\section{Estimativa dos Componentes da Variância}

Os componentes da variância foram obtidos pela decomposição dos quadrados médios da análise da variância conjunta, da seguinte forma:

Variância entre blocos/locais:

$$
\hat{\sigma}_{b}^{2}=\frac{Q_{1}-Q_{5}}{I K}
$$

Var. genética entre populações: $\quad \hat{\sigma}_{p}^{2}=\left(\frac{1}{J K L}\right)\left(\frac{Q_{3}+Q_{10}}{Q_{4}+Q_{0}}\right)$;

Var. genética da interação locais x populações: $\hat{\sigma}_{L x P}^{2}=\left[\frac{L}{J K(L-1)}\right]\left(\frac{Q_{4}+Q_{14}}{Q_{5}+Q_{10}}\right)$;

Var. ambiental entre parcelas: $\quad \hat{\sigma}_{o \alpha}^{2}=\frac{Q_{5}-Q_{14}}{K}$;

Var. genética entre progênies dentro de populações: $\hat{\sigma}_{F / P}^{2}=\frac{Q_{6}-Q_{10}}{J L}$;

Var. genética entre progênies/população 1:

$$
\hat{\sigma}_{p / P 1}^{2}=\frac{Q_{7}-Q_{11}}{J L}
$$

Var. genética entre progênies/população 2: $\quad \hat{\sigma}_{7 / P 2}^{2}=\frac{Q_{8}-Q_{12}}{J L}$;

Var. genética entre progênies/populações 3: $\quad \hat{\sigma}_{F / P 3}^{2}=\frac{Q_{9}-Q_{13}}{J L}$;

Var. genética da interação locais x prog./pop.: $\hat{\sigma}_{L \times F / P}^{2}=\frac{Q_{10}-Q_{14}}{J[L /(L-1)]}$;

Var. gen. da interação locais x prog./pop. 1: $\hat{\sigma}_{L \times F / P 1}^{2}=\frac{Q_{11}-Q_{14}}{J[L /(L-1)]}$;

Var. gen. da interação locais x prog./pop. 2: $\hat{\sigma}_{L \times F / P 2}^{2}=\frac{Q_{12}-Q_{14}}{J[L /(L-1)]}$;

Var. gen. da interação locais x prog./pop. 3: $\hat{\sigma}_{L \times F / P 3}^{2}=\frac{Q_{13}-Q_{14}}{J[L /(L-1)]}$;

Var. ambiental entre sub-parcelas:

$$
\hat{\sigma}_{a b}^{2}=Q_{14}-\frac{\hat{\sigma}_{d}^{2}}{\bar{n}}
$$


Var. fenotípica dentro de populações:

$$
\hat{\sigma}_{d}^{2}=Q_{15}
$$

Os graus de liberdade para o teste $F$ das fontes de variações de locais e interação de locais e populações não são exatos e foram dados pelas estimativas de Satterthwaite (1946).

Graus de liberdade para efeito de populações:

$$
\begin{aligned}
& n_{1}=\frac{\left(Q_{3}+Q_{10}\right)^{2}}{\frac{\left(Q_{3}\right)^{2}}{I-1}+\frac{\left(Q_{10}\right)^{2}}{(L-1)\left[\sum_{i}\left(K_{1}-1\right)\right]}} ; \\
& n_{2}=\frac{\left(Q_{4}+Q_{6}\right)^{2}}{\frac{\left(Q_{4}\right)^{2}}{(L-1)(I-1)}+\frac{\left(Q_{6}\right)^{2}}{\left[\sum_{i}\left(K_{i}-1\right)\right]}}
\end{aligned}
$$

Graus de liberdade para efeito da interação locais x populações:

$$
\begin{aligned}
& n_{1}=\frac{\left(Q_{4}+Q_{14}\right)^{2}}{\frac{\left(Q_{4}\right)^{2}}{(L-1)(I-1)}+\frac{\left(Q_{14}\right)^{2}}{L I(J-1)\left[\sum_{i}\left(K_{i}-1\right)\right]}} ; \\
& n_{2}=\frac{\left(Q_{5}+Q_{10}\right)^{2}}{\frac{\left(Q_{5}\right)^{2}}{L I(J-1)}+\frac{\left(Q_{10}\right)^{2}}{(L-1)\left[\sum_{i}\left(K_{i}-1\right)\right]}}
\end{aligned}
$$

\subsubsection{Decomposição da Interação em Partes Simples e Complexa}

A decomposição da interação em partes simples e complexa foi realizada de acordo com Cruz \& Regazzi (1997). Desta forma o quadrado médio da interação genótipo ambientes é decomposto em sua parte simples e complexa:

Sendo:

$$
\begin{aligned}
& \mathrm{QM}_{\mathrm{dXA}}=\mathrm{S}+\mathrm{C} \\
& \hat{s}=\frac{1}{2}\left(\sqrt{Q_{1}}-\sqrt{Q_{2}}\right)^{2} \\
& \hat{C}=\sqrt{\left(1-r_{g}\right)^{3} Q_{1} Q_{2}}
\end{aligned}
$$




$$
\hat{r}_{8}=\frac{\hat{\sigma}_{F / P}^{2}-\hat{\sigma}_{L x F / P}^{2}}{\sqrt{\hat{\sigma}_{F / P(1)}^{2} \hat{\sigma}_{F / P(2)}^{2}}}
$$

Onde: $\hat{S}=$ parte simples da interação, causada pela diferença de variabilidade genética entre genótipos nos ambientes; $\hat{C}=$ parte complexa, causada pela falta de correlação dos genótipos em relação aos ambientes; $Q_{1}$ e $Q_{2}$ são os quadrados médios de progênies dentro de populações nos ambientes 1 e 2 , repectivamente; $r_{g}=$ correlação entre genótipos e ambientes em casos de efeito de locais fixos; $\hat{\sigma}_{F / P}^{2}=$ variância entre progênies dentro de populações; $\hat{\sigma}_{L F / P}^{2}=$ variância genética da interação genótipo e ambiente; $\hat{\sigma}_{F / P(1)}^{2} \mathrm{e}$ $\hat{\sigma}_{F / P(2)}^{2}=$ variância entre progênies dentro de populações nos ambientes 1 e 2 , respectivamente.

\subsubsection{DEPRESSAO POR ENDOGAMIA}

Para o estudo da depressão por endogamia utilizou-se somente as plantas amostradas simultaneamente para os caracteres quantitativos e para as isoenzimas. Assim, foram criadas 5 classes de distribuição para cada população em cada local, com base no caractere DAP (Tabela 19). A criação de classes específicas para cada população em cada ambiente foi necessária devido às diferenças no desempenho das populações, nos dois locais de ensaio.

Tabela 19. Intervalo de classes da distribuição diamétrica (DAP) de três populações de $C$. legalis em dois locais de ensaio.

\begin{tabular}{ccccccc}
\hline & \multicolumn{2}{c}{ Campinas } & \multicolumn{2}{c}{ Ibicatu } & \multicolumn{2}{c}{ Vassununga } \\
\cline { 2 - 7 } Classe & LA & PE & LA & PE & LA & PE \\
\hline 1 & $<6$ & $<6$ & $\leq 6$ & $\leq 6$ & $\leq 6$ & $<6$ \\
2 & $>6$ a 11 & $6,0 \mathrm{a} 10$ & $>6 \mathrm{a} 11$ & $>6 \mathrm{a}<10$ & $>6 \mathrm{a} 11$ & $6 \mathrm{a} 10$ \\
3 & $>11 \mathrm{a}<17$ & $>10 \mathrm{a}<16$ & $>11 \mathrm{a} 16$ & $\geq 10 \mathrm{a} \leq 15$ & $>11 \mathrm{a}<17$ & $>10 \mathrm{a}<15$ \\
4 & $17 \mathrm{a} 21$ & $15 \mathrm{a}<19$ & $>16 \mathrm{a}<22$ & $>15 \mathrm{a}<19$ & $17 \mathrm{a} 21$ & $15 \mathrm{a}<19$ \\
5 & $>21$ & $\geq 19$ & $\geq 22$ & $\geq 19$ & $>21$ & $\geq 19$ \\
\hline
\end{tabular}

Então, foi estimada a média dos caracteres quantitativos (variável dependente) para cada classe e submetidos a uma análise de regressão linear, para verificar a dependência 
destes em função do índice de fixação (variável independente). A regressão foi realizada segundo (Beiguelman, 1996). O índice de fixação $(\hat{f})$ foi estimado em nível de locos e média entre locos para cada classe, fazendo-se uso das expressões 74 e 75 .

Com o intuito de testar se os locos isoenzimáticos envolvidos na análise estavam sofrendo seleção, ou se não existia diferenças nas freqũências alélicas entre as classes, realizou-se uma análise da variância para freqüências alélicas, com base em Weir (1996), considerando o efeito de grupo como fixo (Tabela 20). Para verificar se os valores da divergência genética entre os grupos $\left(\hat{\varphi}_{G}\right)$ eram diferentes de zero, utilizou-se 10.000 reamostragens bootstrap sobre os locos, através do programa GDA de Lewis \& Zaykin (1999). O modelo estatístico da análise da variância foi:

$$
Y_{i j k}=m+e_{i}+d_{j(i)}+g_{k(i j)}
$$

Onde: $Y_{i j k}=$ frequência do gene $k$, dentro do indivíduo $j$, dentro do grupo $i ; m=$ média geral da freqüência alélica; $e_{i}=$ efeito do grupo $i, \operatorname{com}(i=1,2, . ., e) ; d_{j(i)}=$ efeito do indivíduo $j$, dentro do grupo $i$, com $(j=1,2, . ., d) ; g_{k(j)}=$ efeito do gene $k$, dentro do indivíduo $j$, dentro do grupo $i, \operatorname{com}\left(k=1,2, . ., n_{i j}\right)$.

Os componentes da variância foram obtidos por:

$$
\begin{aligned}
& \hat{\sigma}_{\sigma}^{2}=Q M g \\
& \hat{\sigma}_{i}^{2}=(Q M d-Q M g) / 2 \\
& \hat{\varphi}_{\sigma}=(Q M e-Q M d) / k_{1}
\end{aligned}
$$

\begin{tabular}{|c|c|c|c|}
\hline FV & GL & $\mathrm{QM}$ & $\mathrm{E}(\mathrm{QM})$ \\
\hline Entre grupos & $e-1$ & QMe & $\hat{\sigma}_{G}^{2}+2 \hat{\sigma}_{I}^{2}+K_{1} \hat{\varphi}_{\sigma}$ \\
\hline Individuos/grupos & $\sum_{i}\left(n_{i}-1\right)$ & QMd & $\hat{\sigma}_{\sigma}^{2}+2 \hat{\sigma}_{I}^{2}$ \\
\hline Genes/indiv./grupos & n.. $-\sum n_{i}$ & QMg & $\hat{\sigma}_{a}^{2}$ \\
\hline Total & n. -1 & $\mathrm{QMt}$ & \\
\hline
\end{tabular}

Tabela 20. Análise da variância de freqüêências alélicas entre grupos para modelo fixo.

Por sua vez, a medida de divergência genética entre os grupos foi dada por: 


$$
\hat{\theta}_{G}=\frac{\hat{\varphi}_{\sigma}}{\hat{\sigma}_{\sigma}^{2}+\hat{\sigma}_{I}^{2}+\hat{\varphi}_{\sigma}}
$$

A depressão por endogamia $(\hat{\delta})$ foi quantificada pela expressão:

$$
\hat{\delta}=\left(1-\frac{\bar{x}_{f-\text { maior }}}{\bar{x}_{f-\text { menor }}}\right) x 100
$$

onde: $\bar{x}_{f \text {-maior }}$ e $\bar{x}_{f \text {-menor }}$ referem-se às médias fenotípicas do caractere no grupo de maior e menor índice de fixação. 


\subsubsection{Estimativa da Variância Genética Aditiva em Progênies de Polinização Livre}

Estimou-se a variância aditiva para três situações, considerando a espécie como de cruzamentos aleatórios, como de cruzamento misto sem e com perentesco na geração parental.

\section{a) Modelo de Reprodução Aleatório}

Para este modelo admitiu-se que as progênies de polinização aberta foram geradas por cruzamentos aleatórios, não existia parentesco entre os genitores e os filhos de uma mesma progênie foram gerados por pólen de diferentes indivíduos, sendo desta forma, a relação de parentesco entre individuos dentro das progênies de meios irmãos. Neste caso a variância genética aditiva $\left(\hat{\sigma}_{A}^{2}\right)$ entre progênies foi estimada como:

$$
\hat{\sigma}_{A}^{2}=\frac{4 \hat{\sigma}_{f}^{2}}{\left(1+\hat{f}_{P}\right)}
$$

Sendo: $\hat{\sigma}_{f}^{2}=$ variância genética entre progênies ou covariância genética entre individuos dentro de progênies; $\hat{f}_{P}=$ coeficiente de endogamia da geração parental (Kemphtorne, 1957; Namkoong, 1966). Sendo que com $\hat{f}_{P}=0$ a variância aditiva fica:

$$
\hat{\sigma}_{A}^{2}=4 \hat{\sigma}_{f}^{2}
$$

\section{b) Modelo de Reprodução Mista Sem Parentesco na Geração Parental}

Neste caso, admite-se que as progênies foram geradas em parte por cruzamentos e em parte por autofecundação, sendo que da proporção gerada por cruzamentos, uma parte foi aleatória e outra sistemática, dando origem à progênies constituídas por uma mistura de meios irmãos, irmãos completo e individuos de autofecundação. Admitiu-se também que não existe parentesco na geração parental e que a taxa de cruzamento e autofecundação foi homogênea para todas as árvores matemas. Para tanto, utilizou-se o modelo de Ritland (1989), o qual se distingue do modelo de reprodução mista de Cockerham \& Weir (1984), por admitir que as progênies incluam, além de indivíduos meios irmãos e de autofecundação, irmãos completos. $O$ modelo de Ritland também não exige que as populações estejam em equilibrio de endogamia, portanto, trata-se de um 
modelo mais completo e menos restritivo. Este modelo considera os parâmetros do sistema de reprodução na estimativa dos coeficientes de parentesco para os diversos componentes quadráticos da variância genética. Ritland (1989) sugere a seguinte expressão para a estimativa da variância genética entre progênies $\left(\hat{\sigma}_{f}^{2}\right)$ na presença de sistema misto:

$$
\hat{\sigma}_{f}^{2}=\hat{r}_{x y} \hat{\sigma}_{A}^{2}+\hat{\mu}_{x y} \hat{\sigma}_{D}^{2}+\hat{\vartheta}_{x y} \hat{D}_{1}+\hat{\omega}_{x y} \hat{D}_{2}+\hat{\delta}_{x y} \breve{H}
$$

Sendo:

$$
\begin{aligned}
& \hat{r}_{x y}=\frac{1}{4}\left(1+\hat{f}_{P}\right)\left[4 \hat{s}+\left(\hat{t}^{2}+\hat{s} \hat{t} \hat{r}_{s}\right)\left(1+\hat{r}_{p}\right)\right] \\
& \left.\left.\hat{\mu}_{x y}=\frac{1}{4}\left(1-\hat{f}_{P}\right)\left[\hat{s}^{2}+\hat{s} \hat{t} \hat{r}_{s}\right)+(1+\hat{f})^{2} \cdot\left(\hat{t}^{2}+\hat{s} \hat{t} \hat{r}_{s}\right) \hat{r}_{p}\right)\right] \cdot( \\
& \hat{\vartheta}_{x y}=\frac{1}{2}\left[\left(1+3 \hat{f}_{p}\right)\left(\hat{s}+\hat{s}^{2}+\hat{s} \hat{t} \hat{r}_{s}\right)\right] \\
& \hat{\omega}_{x y}=\frac{1}{4}\left[\hat{f}_{P}\left(1-\hat{f}_{p}\right)\left[\hat{s}^{2}+\hat{s} \hat{t} \hat{r}_{s}\right)\right] \\
& \hat{\delta}_{x y}=\frac{1}{8}\left[\left(1+7 \hat{f}_{p}\right)\left[\hat{s}^{2}+\hat{s} \hat{t} \hat{r}_{s}\right)\right] .
\end{aligned}
$$

Onde: $\hat{f}_{P}=$ coeficiente de endogamia na geração parental; $\hat{s}=$ taxa de autofecundação; $\hat{t}=$ taxa de cruzamento; $\hat{r}_{s}=$ correlação de autofecundação; $\hat{r}_{p}=$ correlação de paternidade; $\hat{\sigma}_{A}^{2}=$ variância genética aditiva; $\hat{\sigma}_{D}^{2}=$ variância de dominância; $\hat{D}_{1}=$ covariância entre efeitos aditivos e de dominância dos homozigotos; $\hat{D}_{2}=$ variância genética dos efeitos de dominância dos homozigotos; $\hat{\delta}_{x y}=$ depressão por endogamia elevada ao quadrado.

Contudo, considerando que não se conhece com precisão a relação exata de parentesco entre cada par de indivíduos dentro das progênies, ou seja, não ter sido possivel distinguir quem era irmão de autofecundação, meio irmão e irmão completo, as estimativas de $\hat{\sigma}_{D}^{2}, D_{l}, D_{2}$ e $\hat{\delta}_{x y}$ não foram passíveis de serem obtidas, sendo obtida apenas a $\hat{\sigma}_{A}^{2}$. Esta foi estimada da seguinte forma: 


$$
\hat{\sigma}_{A}^{2}=\frac{\hat{\sigma}_{f}^{2}}{\hat{r}_{x y}}
$$

Sendo o $\hat{r}_{x y}$ obtido de acordo com a expressão 128.

Como não se conhece parentesco real entre cada par de indivíduos, não é possível estimar os componentes quadráticos das covariâncias entre parentes e as estimativas da herança dos caracteres não é precisa para nenhum dos métodos utilizados.

\section{c) Modelo de Reprodução Mista Com Parentesco na Geração Parental}

Para este modelo considerou-se os mesmos aspectos da situação anterior, ou seja, que a espécie se reproduz por sistema misto, porém, assumindo existir parentesco entre os genitores $\left(\hat{r}_{p p}\right)$, medido pela divergência genética entre populações de individuos adultos $\left(2 \hat{F}_{S T}\right)$. Assim, a estimativa da variância aditiva fica, segundo Squillace (1974):

$$
\hat{\sigma}_{A}^{2}=\frac{\hat{\sigma}_{f}^{2}}{\hat{r}_{x y}-\hat{r}_{p p}}
$$

\subsubsection{Métodos de SELEção}

O estudo de seleção visando o melhoramento das populações de C. legalis foi feito comparando-se dois métodos de seleção, baseados em índices: índice de seleção multi-efeito e índice de seleção entre e dentro de populações. As diferenças básicas entre estes métodos, considerando-se o delineamento experimental de blocos ao acaso, consistem nos seguintes fatos: $O$ método de seleção índice multi-efeito, quando se considera o efeito de blocos aleatório, é baseado simultaneamente nos efeitos de progênies, indivíduos dentro de progênies, parcelas e blocos, logo todos os efeitos do modelo. A seleção entre e dentro de progênies é feita seqüencialmente, primeiro selecionando-se as melhores progênies e, após, os melhores indivíduos destas progênies, porém fixando-se o número de indivíduos por progênies. 
Para possibilitar a comparação entre os dois métodos de seleção, primeiro aplicouse a seleção entre e dentro de progênies, fixando-se desta forma, o número total de indivíduos a serem selecionados, aqui no caso 4, índivíduos por progênie, locados em diferentes blocos, a fim de reduzir a probabilidade de cruzamentos entre plantas de uma mesma progênie. Assim, o número total de indivíduos selecionados entre e dentro de progênies foi utilizado para fixar o número de indivíduos a serem selecionados pelo método índice multi-efeito. Verifica-se a partir disso, que o número de progênies não foi fixado, só o número total de indivíduos por população.

Como as predições de ganhos na seleção são dependentes de parâmetros intrapopulacionais como herdabilidades, acurácias, coeficientes de variação, heterozigosidades, endogamia e parentesco na geração parental, taxa de cruzamento, autofecundação e etc, a seleção foi realizada em nível de populações dentro de locais.

A estimativa dos ganhos para os métodos de seleção foi baseada no modelo linear de blocos ao acaso, em nível de locais, que descreve o valor individual dos candidatos à seleção.

\subsubsection{1 Índice Multi-Efeitos}

a) Modelo do Índice Multi-Efeitos

Os efeitos do modelo índice multi-efeitos em termos de desvios e desconsiderando o efeito de populações ( $i$ ), pode ser escrito segundo Resende \& Riga (1994) como:

$$
Y_{j k z}=\bar{Y}_{\ldots}+\left(\bar{Y}_{j .}-\bar{Y}_{. .}\right)+\left(\bar{Y}_{. k .}-\bar{Y}_{. .}\right)+\left(\bar{Y}_{j k .}-\bar{Y}_{. k .}-\bar{Y}_{j . .}+\bar{Y}_{\ldots}\right)+\left(Y_{j k z}-\bar{Y}_{j k .}\right)
$$

Onde: $\bar{Y}=$ efeito da média geral do caráter,

$$
\begin{aligned}
& \bar{Y}_{k .}=\text { média da progênie } k \text { no ensaio; } \\
& \bar{Y}_{j_{-}}=\text {média do bloco } j \text { no ensaio; } \\
& \bar{Y}_{j k . .}=\text { média da progênie } k \text { no bloco } j ; \\
& \left(\bar{Y}_{j-}-\bar{Y}_{. .}\right)=\text {efeito do bloco } j
\end{aligned}
$$




$$
\begin{aligned}
& \left(\bar{Y}_{k_{-}}-\bar{Y}_{\ldots}\right)=\text { efeito da progênie } k \\
& \left(\bar{Y}_{j k .}-\bar{Y}_{k .}-\bar{Y}_{j-}+\bar{Y}\right)=\text { efeito da sub-parcela, relativa à progênie } k \text { no bloco } j ; \\
& \left(Y_{j k z}-\bar{Y}_{j k .}\right)=\text { efeito do individuo } z \text { da parcela } j k
\end{aligned}
$$

b) Variâncias Associadas aos Efeitos Incluídos no Índice

As diversas variâncias associadas ao índice de seleção, para a maximização da eficiência de seleção, foram estimadas de acordo com Resende \& Riga (1994b).

Efeito de individuo dentro da sub-parcela:

$$
\operatorname{Var}\left(Y_{j k z}-\bar{Y}_{j k .}\right)=\left(\frac{\bar{n}-1}{\bar{n}}\right) \hat{\sigma}_{d}^{2}=\left(1-\frac{1}{\bar{n}}\right) \hat{\sigma}_{d}^{2}
$$

Efeito de progênie:

$$
\operatorname{Var}\left(\bar{Y}_{k .}-\bar{Y}\right)=\left(\frac{J-1}{J}\right)\left(\hat{\sigma}_{f}^{2}+\frac{\hat{\sigma}_{e}^{2}}{J}+\frac{\hat{\sigma}_{d}^{2}}{\bar{n} J}\right)
$$

Obs: Para o caso do número de progênies ser grande $(p>100)$, a expressão tende a:

$$
\operatorname{Var}\left(\bar{Y}_{. x .}-\bar{Y}\right)=\left(\hat{\sigma}_{f}^{2}+\frac{\hat{\sigma}_{e}^{2}}{J}+\frac{\hat{\sigma}_{d}^{2}}{\bar{n} J}\right)
$$

Efeito de sub-parcela:

$$
\operatorname{Var}\left(\bar{Y}_{j k .}-\bar{Y}_{. k .}-\bar{Y}_{j .}+\bar{Y}\right)=\left(\frac{K-1}{K}\right)\left(\frac{J-1}{J}\right)\left(\hat{\sigma}_{e}^{2}+\frac{\hat{\sigma}_{d}^{2}}{\bar{n}}\right)
$$

Efeito de bloco:

$$
\operatorname{Var}\left(\bar{Y}_{j .}-\bar{Y}\right)=\left(\frac{J-1}{J}\right)\left(\hat{\sigma}_{b}^{2}+\frac{\hat{\sigma}_{e}^{2}}{K}+\frac{\hat{\sigma}_{d}^{2}}{\bar{n} K}\right)
$$

Onde: $\bar{n}=$ média harmônica do número de plantas por sub-parcelas; $J=$ número de repetições (aqui igual a blocos); $K=$ número de progênies; $\hat{\sigma}_{A}^{2}=$ variância genética 
aditiva; $\hat{\sigma}_{f}^{2}=$ variância genética entre progênies; $\hat{\sigma}_{e}^{2}=$ variância ambiental entre subparcelas; $\hat{\sigma}_{d}^{2}=$ variância fenotípica dentro de sub-parcelas; $\hat{\sigma}_{b}^{2}=$ variância entre blocos.

\section{c) Estimativa da Acurácia do Método de Seleção Índice Multi-Eefeitos}

As estimativas de acurácia para os métodos de seleção índice multi-efeito foi obtida segundo Resende, et al. (1995):

$$
\hat{r}_{L A}=\sqrt{\left(\frac{\bar{n}-1}{\bar{n}}\right)(1-r)^{2} \frac{\hat{\sigma}_{A}^{2}}{\hat{\sigma}_{d}^{2}}+\left(\frac{K-1}{K}\right)\left[\frac{1+(\bar{n} J-1) r}{\bar{n} J}\right]^{2} \frac{\hat{\sigma}_{A}^{2}}{\hat{\sigma}_{\bar{F}}^{2}}+\left(\frac{J-1}{J}\right)\left(\frac{K-1}{K}\right)\left(\frac{1-r}{\bar{n}}\right)^{2} \frac{\hat{\sigma}_{A}^{2}}{\hat{\sigma}^{2}}}
$$

Onde: $r=$ coeficiente de covariância genética aditiva entre progênies, estimado de acordo com o ítem $3.4 .4 ; \hat{\sigma}_{\bar{F}}^{2}=$ variância fenotípica em nível de progênies; $\hat{\sigma}_{B}^{2}=$ variância fenotípica em nível de bloco.

\section{d) Estimativa dos Valores Genéticos e Ganhos na Seleção}

Este método de seleção baseia-se na multiplicação dos valores fenotípicos referentes ao indivíduo, média de progênies, média de sub-parcela, média de bloco e média geral do experimento pelos coeficientes de herdabilidades referentes a cada efeito (Resende \& Riga, 1994b). Os coeficientes são determinados de forma que a correlação entre o índice e o valor genético seja máxima. Estes coeficientes do índice corresponde às herdabilidades associadas aos efeitos de indivíduos dentro de progênies $\left(\hat{h}_{d}^{2}\right)$, de progênies $\left(\hat{h}_{f}^{2}\right)$, de sub-parcelas $\left(\hat{h}_{p}^{2}\right)$ e de blocos $\left(\hat{h}_{b}^{2}\right)$, definidas no ítem 3.4.2.1. A expressão do índice de seleção multi-efeito, para a estimativa do valor genético (I), segundo Resende \& Higa (1994b), com a seleção baseada em desvios, adequada quando se tem mais de uma planta por sub-parcela é:

$I=\hat{h}_{d}^{2}\left(Y_{j k z}-\bar{Y}_{j k .}\right)+\hat{h}_{f}^{2}\left(\bar{Y}_{k .}-\bar{Y}\right)+\hat{h}_{p}^{2}\left(\bar{Y}_{j k .}-\bar{Y}_{k .}-\bar{Y}_{j .}+\bar{Y}_{-}\right)+\hat{h}_{b}^{2}\left(\bar{Y}_{j .}-\bar{Y}\right)$ 
Os ganhos genéticos referem-se à média dos valores genéticos dos indivíduos selecionados entre e dentro de progênies.

\section{e) Intervalo de Confiança de Ganhos Genéticos}

$O$ intervalo de confiança dos ganhos genéticos para este método de seleção foram construídos considerando a variância do erro associado aos valores genéticos aditivos preditos. Resende et al. (1995) mostraram que a variância do erro associado ao valor genético médio dos indivíduos selecionados (ganhos genéticos) equivale a:

$$
V(G s)=E\left(\frac{1}{n} \sum_{i=1}^{n} A_{j}-\frac{1}{n} \sum_{i=1}^{n} \hat{A}_{j}\right)^{2}=\frac{\hat{\sigma}_{A}^{2}\left(1-\hat{r}_{I A}\right)}{n}
$$

Onde: $n=$ número de indivíduos selecionados; $\hat{r}_{I A}=$ acurácia; $A_{1}=$ valor genético verdadeiro do indivíduo; $\hat{A}_{j}=$ valor genético estimado para o indivíduo.

Desta forma, o intervalo de confiança do ganho genético (IC) é estimado pela expressão (Resende, et al., 1995):

$$
I C=G s \pm t \cdot \sqrt{\frac{\hat{\sigma}_{A}^{2}\left(1-\hat{r}_{I A}\right)}{n}}
$$

Sendo: $t=$ valor tabela da distribuição de $t$ (usou-se aqui $t$ a $95 \%$ de probabilidade para rejeitar ou aceitar a hipótese verdadeira).

A estimativa do intervalo de confiança permite determinar qual o método de maior precisão. Métodos de maior acurácia apresentam intervalos mais amplos, portanto não devem ser analisados os limites superiores do intervalo para a escolha do melhor método, mas sim, os inferiores. A seleção de um pequeno número de indivíduos permite um maior limite de confiança, mas deve-se considerar que existe $50 \%$ (quando se trabalha com nível de significância próximo a $100 \%$ ) de chances do verdadeiro ganho genético situar-se entre o limite inferior e o ganho genético médio estimado (Resende, et al., 1995). 


\subsubsection{Seleção Entre e Dentro de Progênies}

a) Variâncias Associadas aos Efeitos Incluídos no Índice

As variâncias associadas à seleção entre e dentro de progênies foram estimadas de acordo com Resende \& Riga (1994b).

Efeito de individuo dentro da sub-parcela:

$$
\operatorname{Var}\left(Y_{j k}-\bar{Y}_{j k .}\right)=\left(\frac{\bar{n}-1}{\bar{n}}\right) \hat{\sigma}_{d}^{2}=\left(1-\frac{1}{\bar{n}}\right) \hat{\sigma}_{d}^{2}
$$

Efeito de progênie:

$$
\operatorname{Var}\left(\bar{Y}_{k .}-\bar{Y}_{\ldots .}\right)=\left(\frac{J-1}{J}\right)\left(\hat{\sigma}_{f}^{2}+\frac{\hat{\sigma}_{e}^{2}}{J}+\frac{\hat{\sigma}_{d}^{2}}{\bar{n} J}\right)
$$

Obs: Para o caso do número de progênies ser grande $(p>100)$ a expressão tende $a$ :

$$
\operatorname{Var}\left(\bar{Y}_{. k .}-\bar{Y}\right)=\left(\hat{\sigma}_{f}^{2}+\frac{\hat{\sigma}_{e}^{2}}{J}+\frac{\hat{\sigma}_{d}^{2}}{\bar{n} J}\right)
$$

Sendo que: $\bar{n}, J, K, \hat{\sigma}_{A}^{2}, \hat{\sigma}_{f}^{2}, \hat{\sigma}_{\varepsilon}^{2}, \hat{\sigma}_{d}^{2}$ e $\hat{\sigma}_{b}^{2}$, já foram definidos.

b) Estimadores de Acurácia da Seleção Entre e Dentro de Progênies

As estimativas de acurácia para este métodos de seleção foram obtidas segundo Resende et al. (1995):

a) Para a seleção entre progênies:

$$
\hat{r}_{I A}=\sqrt{\left(\frac{K-1}{K}\right)}\left(\frac{1+(\bar{n} J-1) r}{\bar{n} J}\right) \frac{\hat{\sigma}_{A}}{\hat{\sigma}_{\bar{F}}}
$$

b) Para a seleção dentro de progêmies:

$$
\hat{r}_{L A}=\sqrt{\left(\frac{\bar{n}-1}{\bar{n}}\right)}(1-r) \frac{\hat{\sigma}_{A}}{\hat{\sigma}_{d}}
$$


Onde: $\hat{\sigma}_{A}=$ desvio padrão da variância genética aditiva; $\hat{\sigma}_{\bar{F}}=$ desvio padrão da variância fenotípica média em nível de progênies; $\hat{\sigma}_{d}=$ desvio padrão da variância fenotípica dentro de progênies.

\section{c) Estimativa dos Valores Genéticos e Ganhos na Seleção}

A seleção entre e dentro de progênies é a combinação de dois métodos: primeiro selecionam-se as melhores progênies e depois as melhores plantas das progênies selecionadas. Este método é uma forma de amenizar a seleção entre progênies e dentro de progênies, sendo muito eficiente quando o $\left(\hat{N}_{e}\right)$ é predeterminado, como restrição de seleção, podendo-se optar pela combinação que propicie maior ganho (Leonardecz Neto, 1998).

A seleção entre progênies, em um experimento com repetições e várias plantas por parcela, baseia-se na média de cada progênies $\left(\bar{Y}_{. t .}\right)$ em relação à média de todas as progênies $\left(\bar{Y}_{\text {... }}\right)$ (Resende, 1991). Assim, o valor genético de cada progênie pode ser expresso pelo desvio da média de dada progênie em relação a média geral multiplicado pela herdabilidade entre progênies.

$$
I=\hat{h}_{f}^{2}\left(Y_{k .}-\bar{Y}\right)
$$

Progênies inteiras são rejeitadas ou selecionadas como unidades, de acordo com os valores fenotípicos médios. $O$ valor genético dos indivíduos dentro das progênies é estimado através do desvio entre o valor fenotípico individual $\left(\bar{Y}_{j k z}\right)$ em relação a média da progênies a qual pertence $\left(\bar{Y}_{j k_{n}}\right)$. Desta forma, o valor genético é dado em função deste desvio que é multiplicado pela herdabilidade dentro de progênies.

$$
I=\hat{h}_{d}^{2}\left(Y_{j k z}-\bar{Y}_{j k .}\right)
$$

Seleção Entre e Dentro de Progênies

$$
I=\hat{h}_{f}^{2}\left(Y_{. k .}-\bar{Y}_{. .}\right)+\hat{h}_{d}^{2}\left(Y_{j k z}-\bar{Y}_{j k .}\right)
$$


Os ganhos genéticos referem-se a média dos valores genéticos dos individuos selecionados entre e dentro de progênies.

d) Intervalo de Confiança de Ganhos Genéticos

$O$ intervalo de confiança do ganho entre e dentro de progênies foi estimado igualmente ao método de seleção índice multi-efeito (item 3.4.5.1.e).

e) Tamanho Efetivo $\left(\hat{N}_{e}\right)$

O tamanho efetivo das populaçães antes e depos da seleção foi estimado com base em Vencovsky (1997). Para progênies maternas de uma simples população o tamanho efetivo é:

$$
\hat{N}_{e}=\frac{0,5}{\hat{\theta}_{f}\left(\frac{1+\hat{C}_{f}}{m}-\frac{1}{n}\right)+\frac{1+\hat{F}}{2 n}}
$$

Onde o $\hat{\theta}_{f}$ é a coancestria entre indivíduos dentro de progênies ou a divergência genética entre progênies, $m$ é o número de parentais ou de progênies avaliadas, $n$ é o número total de indivíduos avaliados nas progênies $\left(n=\sum n_{i}\right) ; C_{f}$ é o quadrado do coeficiente de variação do número de indivíduos $\left(n_{i}\right)$ avaliados nas progênies $(i=1,2, \ldots, f)$ e $\hat{F}$ é o índice de fixação para o conjunto das progênies. 


\section{Resultados E Discussões}

\subsection{SISTEMas ISOEZIMÁticos}

Os nove sistemas isoenzimáticos avaliados revelaram dezessete zonas de atividades, sendo 14 passiveis de interpretação. O sistema ACP apresentou três zonas de atividades, mas apenas a região mais anódica apresentou-se passível de interpretação. Esta região foi interpretada como um loco polimórfico, composta por uma enzima monomérica, com dois alelos. A $\alpha \mathrm{EST}$ apresentou duas zonas de atividades, interpretadas como locos polimórficos de expressões monoméricas, com quatro alelos. A PGI e a $\mathrm{MDH}$ também apresentaram duas zonas de atividades, interpretadas como locos polimórficos, compostas por enzimas de expressão dimérica, com até quatro alelos/loco. A PRX apresentou quatro locos polimórficos de expressão monomérica, no entanto, a enzima mais anódica não foi passível de interpretação devido à baixa constância e qualidade da resolução. Na PRX, os locos 1 e 2 apresentaram três alelos e o loco 3 quatro alelos. Os sistemas 6PGDH, SKDH, G6PDH e IDH apresentaram apenas uma zona de atividade, contudo, polimórfica. $\mathrm{O}$ três primeiros, apresentaram enzimas de expressões monoméricas e a última, dimérica. O sistema 6PGDH apresentou três alelos e a SKDH, G6PDH e IDH apresentaram dois alelos.

\subsection{SISTEMA DE REPRODUÇÃO}

a) Teste de Equilíbrio de Hardy-Weinberg e Endogamia de Wright

O sistema de reprodução das populações de $C$. legalis foi inicialmente caracterizado pelo teste de Equilíbrio de Hardy-Weinberg (EHW), a partir do teste exato de Fisher (Tabela 21). Este teste é o mais adequado quando existem frequências esperadas inferiores a $5 \%$. O teste de Fisher revelou desvios das freqüências genotípicas observadas das esperadas pelo modelo de EHW, em $71,4 \%$ dos locos na população Campinas, $85,7 \%$ na Ibicatu e 78,6\% na Vassununga. Desvios do EHW podem ser causados pelo sistema de reprodução ou por fatores evolutivos como seleção, migração, mutação ou deriva 
genética. $O$ teste de Equilibrio de Endogamia de Wright (EEW) permite conhecer se os desvios do teste de EHW foram causados pelo sistema de reprodução ou devido a fatores evolutivos.

Na população Campinas, cinco dos sete locos ( $\alpha$ Est-2, Pgi-2; Prx-1, Prx2 e Prx3), na Ibicatu três dos seis (Pgi-2, Prx2 e Prx-3) e na Vassununga quatro dos sete locos ( $\alpha$ Est-2, Pgi-2, Prx-2 e Prx-3) avaliados, respectivamente, apresentaram desvio do modelo de EEW, indicando a atuação de forças evolutivas, possivelmente, seleção para heterozigotos.

Tabela 21. Probabilidades do teste exato de Fisher para o Equilibrio de Hardy-Weinberg (EHW) e teste de qui-quadrado $\left(\chi^{2}\right)$ para o teste de Equilibrio de Endogamia de Wright (EEW) em populações de $C$. legalis.

\begin{tabular}{|c|c|c|c|c|c|c|}
\hline \multirow[t]{2}{*}{ Loco } & \multicolumn{2}{|c|}{ Pop. Campinas } & \multicolumn{2}{|c|}{ Pop. Tbicatu } & \multicolumn{2}{|c|}{ Pop. Vassununga } \\
\hline & EHW $(P)$ & $\operatorname{EEW}\left(\chi^{2}\right)$ & $\mathrm{EHW}(P)$ & $\operatorname{EEW}\left(\chi^{2}\right)$ & $\mathrm{EHW}(P)$ & $\mathrm{EEW}\left(\chi^{2}\right)$ \\
\hline Acp-3 & $0,000 * *(1)$ & - & $0,000 * *(1)$ & - & $0,000 * *(1)$ & - \\
\hline$\alpha$ Est-1 & $0,452 \quad(6)$ & - & $0,405 \quad(0)$ & $\cdots$ & $0,168 \quad(6)$ & - \\
\hline$\alpha$ Est-2 & $0,000^{* *}(3)$ & $21,08 * *(2)$ & $0,005 * *(6)$ & 1,49 & $0,049 *(6)$ & $17,47 * *(5)$ \\
\hline Pgi-1 & $0,734 \quad$ (1) & - & $0,000 * *(3)$ & $4,27 \quad(5)$ & $0,751 * *(1)$ & - \\
\hline Pgi-2 & $0,000 * *(1)$ & $31,14 * *(2)$ & $0,000 * *(3)$ & $17,59 * *(5)$ & $0,000 * *(3)$ & $11,92 * *(2)$ \\
\hline Mdh-1 & $0,036 *(3)$ & $0,03 \quad(2)$ & $0,229 \quad$ (1) & - & 0,032 & $1,44 \quad(2)$ \\
\hline Mdh-2 & $0,042 *(3)$ & 1,75 & $0,002 *(1)$ & $\cdots$ & 0,134 & $\ldots$ \\
\hline Prx-1 & $0,000 * *$ (3) & $6,71 * \quad(2)$ & $0,000 * *(3)$ & $-\cdots$ & $0,000 * *(3)$ & $0,98 \quad(2)$ \\
\hline Prx-2 & $0,000^{* *}(1)$ & $21,36 * *(2)$ & $0,000 * *(3)$ & $14,95 * *$ (2) & $0,000 * *(3)$ & $7,43 * *(2)$ \\
\hline Prx-3 & $0,000^{* *}(3)$ & $8,59 * *(2)$ & $0,000^{* *}(6)$ & $13,96 * *(5)$ & $0,000^{* *}(3)$ & $22,55 * *(5)$ \\
\hline 6Pgdhl & 0,077 & - & $0,000 * *(3)$ & $0,50 \quad(2)$ & $0,000 * *(3)$ & $2,31 \quad(2)$ \\
\hline Skdh-1 & $0,000 * *(1)$ & $\cdots$ & $0,000^{* *}(1)$ & $\ldots$ & $0,000^{* *}(1)$ & -.. \\
\hline G6pdh1 & $0,642 \quad(10)$ & $\ldots$ & $0,008 * *(1)$ & -...- & $0,241 * *(1)$ & $\cdots$ \\
\hline Idh-1 & $0,000^{* *}(1)$ & - & $0,000^{* *}(1)$ & $\ldots$ & $0,000^{* *}(1)$ & - \\
\hline
\end{tabular}

$*: P \leq 0,05 ; * *: P \leq 0,01$;

(): graus de liberdade.

b) Homogeneidade nas Frequiências Alélicas dos Óvulos e do Pólen

O teste de homogeneidade das frequiências alélicas dos óvulos e do pólen (Tabela 22) mostrou diferenças significativas para quase todos os locos avaliados nas três populações, exceto para o loco Acp-3 na população Campinas, Skdh-1 na Ibicatu e Acp-3 e Skdh-1 na Vassununga, sugerindo que a distribuição do pólen não foi homogênea para os cruzamentos individuais. A heterogeneidade nas frequiências alélicas do conjunto gênico materno e paterno pode ter quatro origens: primeiro, diferenças nas funções 
masculina e feminina das plantas. Apesar de a espécie ter flores hermafroditas, é possível que os órgãos masculinos e femininos entrem em reprodução em diferentes fases na mesma planta; segundo, imigração de pólen de fora das populações amostradas. Não foram detectados alelos privados entre os dois conjuntos gênicos (pólen e óvulos), portanto não há indícios de contaminação de pólen de outras populações; terceiro, seleção entre o periodo de polinização e a análise de isoenzimas. Esta é a hipótese mais provável, dado que decorreram 17 anos entre o evento reprodutivo e a revelação das isoenzimas. Ressalta-se que a hipótese de seleção é fundamentada na provável ligação entre locos isoezimáticos e locos adaptativos; quarto, devido a amostragem não representativa das árvores maternas. Hipótese pouco provável porque todas as árvores foram amostradas nas populações Campinas e Ibicatu e na Vassununga foram amostradas 22 árvores, um número muito próximo ao recomendado na literatura (25: Brown \& Hardner, 2000) para a caracterização do sistema de reprodução de populações de espécies arbóreas. Contudo, segundo Ritland \& Jain (1981), violações da pressuposição de homogeneidade das frequiências alélicas dos óvulos e do pólen têm pouco efeito sobre a estimativa da taxa de cruzamento multilocos da população $\left(\hat{t}_{m}\right)$ quando um grande número de locos é usado para as estimativas, como por exemplo, mais de quatro ou cinco. Como foram utilizados 14 locos para as estimativas de $\hat{t}_{m}$, acredita-se que os resultados obtidos sejam robustos.

\section{c) Taxa de Cruzamento}

A taxa $\hat{t}_{m}$ foi alta e significativamente diferente de 1,0 para todas as populações, variando de 0,901 a 0,990 , mostrando que a espécie se reproduz por cruzamento misto predominantemente por alogamia (Tabela 23). As taxas de cruzamentos unilocos $\left(\hat{t}_{s}\right)$ foram significativamente menores que as estimativas da taxa $\hat{t}_{m} \mathrm{em}$ todas as populações (mínimo 0,830), indicando uma alta proporção de cruzamentos entre individuos não aparentados nas populações. As taxas de cruzamentos entre aparentados $\left(\hat{t}_{p}\right)$ variaram de 0,059 a 0,091, demostrando que existem parentescos dentro das populaçбes naturais de $C$. legalis, as populações encontram-se estruturadas e certa proporção de endogamia pode ser gerada por estes cruzamentos. 


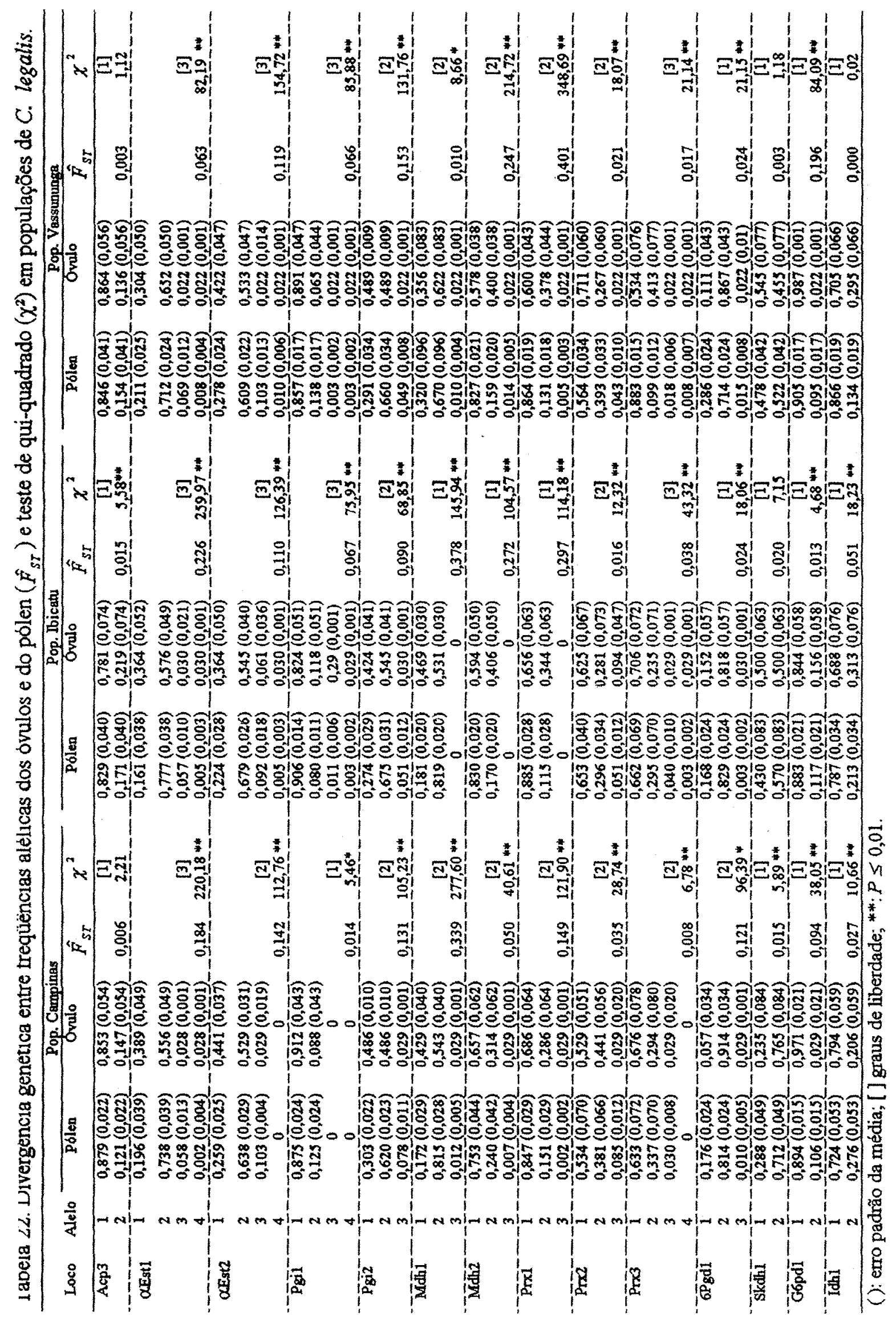


Tabela 23. Taxas de cruzamentos individuais por progênie (Prog.), entre não aparentados $\left(\hat{t}_{s}\right)$, entre não aparentados + aparentados $\left(\hat{t}_{m}\right)$, entre aparentados $\left(\hat{t}_{p}=\hat{t}_{m}\right.$ $\left.\hat{t}_{s}\right)$, taxa de autofecundação $\left(\hat{s}=1-\hat{t}_{m}\right)$, correlação na estimativa de $t\left(\hat{r}_{s}\right)$, correlação na estimativa de $p\left(\hat{r}_{p}\right)$ e coeficiente de endogamia da geração parental $\left(\hat{f}_{p}\right)$ em populações de $C$. legalis.

\begin{tabular}{|c|c|c|c|c|c|}
\hline Prog. & Pop. Campinas & Prog. & Pop. Ibicatu & Prog. & Pop. Vassununga \\
\hline 1 & $1,00(0,02)-[23]$ & 18 & $1,00(0,00)-[30]$ & 34 & $0,67(0,16)-[09]$ \\
\hline 2 & $1,00(0,00)-[19]$ & 19 & $0,94(0,07)-[26]$ & 35 & $0,93(0,06)-[22]$ \\
\hline 3 & $1,00(0,00)-[28]$ & 20 & $0,96(0,05)-[23]$ & 36 & $0,64(0,16)-[22]$ \\
\hline 4 & $0,97(0,05)-[25]$ & 21 & $1,00(0,00)-[27]$ & 37 & $0,95(0,06)-[21]$ \\
\hline 5 & $0,92(0,07)-[24]$ & 22 & $1,00(0,04)-[20]$ & 38 & $0,90(0,09)-[16]$ \\
\hline 6 & $1,00(0,01)-[17]$ & 23 & $1,00(0,00)-[31]$ & 39 & $0,81(0,12)-[20]$ \\
\hline 7 & $1,00(0,00)-[27]$ & 24 & $0,89(0,09)-[22]$ & 40 & $0,94(0,07)-[13]$ \\
\hline 8 & $1,00(0,02)-[30]$ & 25 & $0,92(0,10)-[23]$ & 41 & $0,84(0,12)-[23]$ \\
\hline 9 & $0,99(0,04)-[28]$ & 26 & $1,00(0,00)-[27]$ & 42 & $1,00(0,00)-[21]$ \\
\hline 10 & $0,98(0,04)-[20]$ & 27 & $0,98(0,03)-[24]$ & 43 & $1,00(0,07)-[14]$ \\
\hline 11 & $1,00(0,00)-[24]$ & 28 & $0,87(0,10)-[22]$ & 44 & $0,93(0,07)-[13]$ \\
\hline 12 & $1,00(0,00)-[21]$ & 29 & $0,94(0,10)-[21]$ & 45 & $1,00(0,00)-[17]$ \\
\hline 13 & $1,00(0,00)-[17]$ & 30 & $1,00(0,00)-[22]$ & 46 & $0,90(0,07)-[25]$ \\
\hline 14 & $1,00(0,00)-[31]$ & 31 & $1,00(0,00)-[25]$ & 47 & $1,00(0,00)-[16]$ \\
\hline 15 & $0,99(0,03)-[28]$ & 32 & $0,91(0,07)-[28]$ & 48 & $0,91(0,14)-[20]$ \\
\hline 16 & $0,96(0,07)-[27]$ & 33 & $0,96(0,05)-[15]$ & 49 & $1,00(0,02)-[22]$ \\
\hline 17 & $1,00(0,04)-[21]$ & -- & $\ldots$ & 50 & $0,81(0,14)-[20]$ \\
\hline-- & $-\cdots$ & -- & --. & 51 & $1,00(0,00)-[25]$ \\
\hline-- & -- & - & - & 52 & $0,86(0,11)-[22]$ \\
\hline- & $-\ldots$ & - & $\cdots$ & 53 & $0,96(0,08)-[26]$ \\
\hline - & $\ldots$ & - & - & 54 & $0,99(0,07)-[25]$ \\
\hline -- & $\cdots$ & -- & - & 55 & $1,00(0,04)-[24]$ \\
\hline$\hat{t}_{s}$ & $0,899(0,016)$ & & $0,916(0,014)$ & & $0,830(0,032)$ \\
\hline$\hat{t}_{m}$ & $0,990(0,009)$ & & $0,976(0,011)$ & & $0,901(0,025)$ \\
\hline$\hat{t}_{p}{ }^{2}$ & $0,091(0,012)$ & & $0,059(0,011)$ & & $0,070(0,025)$ \\
\hline$\hat{s}^{b}$ & 0,001 & & 0,024 & & 0,099 \\
\hline$\hat{r}_{s}$ & $0,101(0,005)$ & & $0,093(0,008)$ & & $0,076(0,009)$ \\
\hline$\hat{r}_{p}$ & $0,324(0,045)$ & & $0,295(0,045)$ & & $0,212(0,033)$ \\
\hline$\hat{f}_{p}$ & $0,0(0,0)$ & & $0,0(0,0)$ & & $0,0(0,0)$ \\
\hline
\end{tabular}

(): erro padrão da média;

[]: número de individuos amostrados nas progênies. 
Ainda, a julgar pelos erros padrões das médias das estimativas de $\hat{t}_{p}$, pode-se considerar que os cruzamentos entre aparentados foram estatisticamente significativos. As correlações nas estimativas de $t\left(\hat{r}_{S}\right)$ ou a probabilidade de encontrar-se um indivíduo gerado por autofecundação em uma progênie onde existe outro também gerado por autofecundação, variaram entre as populações de 0,076 a 0,101 , revelando que os indivíduos advindos de autofecundações encontram-se aleatoriamente distribuídos dentro das progênies, e não existe a tendência de algumas plantas maternas gerarem mais indivíduos por autofecundações do que outras.

A correlação da estimativa de $p\left(\hat{r}_{p}\right)$ ou a probabilidade de encontrar indivíduos irmãos completos no conjunto das progênies de cruzamento foi alta, variando de 0,212 a 0,324 . Isto suge a presença de cruzamentos preferenciais dentro das populações e que as progênies oriundas de cruzamentos não são compostas exclusivamente por meios irmãos, incluindo, também irmãos completos. Este parâmetro permite estimar o número médio provável de polinizadores que contribuíram para os cruzamentos (Ritland, 1989). Na média, as progênies da população Campinas e Ibicatu foram geradas por quatro diferentes pais $(1 / 0,324=3,1 ; 1 / 0,295=3,4)$ e a Vassununga por cinco pais $(1 / 0,212=4,7)$.

Nenhum dos parâmetros do sistema de reprodução estimados diferiram estatisticamente entre a população Campinas e Ibicatu (populações pequenas com 17 e 16, individuos, respectivamente), com exceção da estimativa de $\hat{t}_{p}$. Porém, os parâmetros $\hat{t}_{m}, \hat{t}_{s}$ e $\hat{r}_{p}$ diferiram destas duas populações em relação à Vassununga. Apenas os parâmetros $\hat{t}_{p}$ e $\hat{r}_{S}$ não foram estatisticamente significativos entre as populações.

As taxas de cruzamentos individuais por árvore materna (Tabela 23), foram altas para a maioria dos cruzamentos, não variando muito dentro das populações. Na população Campinas, seis das 17 progênies, avaliadas apresentaram valores inferiores a 1,0, contudo, a julgar pelo erro padrão da média entre locos, apenas a progênie 5 apresentou valores estatisticamente menores do que 1,0. Na população Ibicatu, nove das dezesseis progênies avaliadas apresentaram valores inferiores a 1,0 , com três valores significativos (progênies 25, 28 e 32), sendo o menor valor de 0,87 (progênie 28). Na população Vassununga, 
quinze das vinte e duas progênies avaliadas apresentaram valores diferentes da unidade, sendo nove significativamente diferentes de 1,0 (progênies $34,35,36,38,39,41,46,50$ e 52) e o menor valor estimado, de 0,64 (progênie 36 ).

\section{d) Índices de Fixação}

Os indices de fixação nas progênies $(\hat{f})$ variaram consideravelmente entre os locos dentro das populações, porém, estas variações podem ser atribuídas a erros de amostragem, dado que o número de indivíduos genotipados não permitiu que fossem encontrados individuos em todas as classes genotípicas possíveis (Tabela 24).

Tabela 24. Tamanho da amostra $(n)$ e índice de fixação $(\hat{f})$ em populações de C. legalis.

\begin{tabular}{|c|c|c|c|c|c|c|c|c|c|}
\hline & \multicolumn{3}{|c|}{ Pop. Campinas } & \multicolumn{3}{|c|}{ Pop. Ibicatu } & \multicolumn{3}{|c|}{ Pop. Vassunumga } \\
\hline & $n$ & $\hat{f}$ & & $n$ & $\hat{f}$ & & $n$ & $\hat{f}$ & \\
\hline Acp-3 & 379 & 0,292 & $* *$ & 380 & 0,336 & $* * *$ & 430 & 0,461 & $* *$ \\
\hline Est-1 & 399 & 0,070 & $* *$ & 384 & 0,055 & $* *$ & 435 & 0,078 & $* *$ \\
\hline Est-2 & 398 & 0,245 & $* *$ & 383 & 0,154 & $* *$ & 435 & 0,147 & $* *$ \\
\hline Pgi-1 & 392 & 0,015 & $*$ & 380 & 0,262 & $* *$ & 434 & 0,009 & \\
\hline Pgi-2 & 403 & 0,401 & $* *$ & 382 & 0,341 & $* *$ & 431 & 0,250 & $* *$ \\
\hline Mdh-1 & 410 & $-0,100$ & $*$ & 386 & 0,066 & $* *$ & 436 & $-0,098$ & $* *$ \\
\hline Mdh-2 & 410 & 0,107 & $* *$ & 385 & 0,167 & *** & 435 & $-0,064$ & $* *$ \\
\hline PTX-1 & 410 & 0,199 & ** & 385 & 0,196 & $* * *$ & 435 & 0,271 & ** \\
\hline $\operatorname{Prx}-2$ & 406 & 0,476 & *** & 385 & 0,345 & $* *$ & 435 & 0,343 & ** \\
\hline Prx-3 & 405 & 0,512 & *** & 380 & 0,427 & $* *$ & 419 & 0,559 & *** \\
\hline 6 Pgdh-1 & 399 & 0,104 & $* *$ & 379 & 0,299 & $* *$ & 436 & 0,218 & $* *$ \\
\hline Skdh-1 & 405 & 0,328 & $* *$ & 363 & 0,283 & $* *$ & 434 & 0,273 & $* *$ \\
\hline G6pdh-1 & 404 & 0,027 & $* *$ & 363 & 0,160 & $* *$ & 430 & $-0,069$ & $* *$ \\
\hline Idh-1 & 398 & 0,295 & $* *$ & 360 & 0,240 & $* *$ & 432 & 0,392 & $* *$ \\
\hline Média & & 0,249 & $* *$ & & 0,242 & $* *$ & & 0,220 & ** \\
\hline IC $(95 \%)$ & & 34 a 0,3 & & & $176 \mathrm{a} \mathrm{O}_{2}$ & & & $(0,110 \mathrm{a}$ & 325) \\
\hline
\end{tabular}

$*: P \leq 0,05 ; * *: P \leq 0,01$

(): Intervalo de confiança a $95 \%$ de probabilidade, estimado a partir de 10.000 reamostragem bootstraps.

Para a média entre locos, os índices $\hat{f}$ foram altos e significativamente diferentes de zero nas três populações (média entre populações de 0,237), porém, não foram estatisticamente diferentes entre as populações. A estimativa do coeficiente de endogamia $\hat{f}_{p}$ da geração parental (Tabela 23) evidenciou a ausência de endogamia nas populações naturais, dando a entender que a endogamia observada nas progênies não ocorreu pelo 
acúmulo de endogamia de diferentes gerações, mas sim, possivelmente, devido as taxas de autofecundaçōes e aos cruzamentos entre aparentados. O parentesco entre os genitores aumenta tanto a endogamia como o parentesco entre as progênies, acima do esperado em populações de cruzamentos aleatórios, sem parentesco na geração parental.

\section{e) Considerações Sobre o Sistema de Reprodução}

As altas taxas de cruzamentos multilocos detectada para as três populações mostrou que a espécie é de reprodução mista predominantemente alógama. No entanto, acredita-se que estas estimativas possam estar superestimadas, devido à grande probabilidade de ter ocorrido seleção contra indivíduos de autofecundação e cruzamentos entre indivíduos aparentados, entre o evento reprodutivo (1981), que deu origem às progênies e o momento da amostragem (1999). Considerando tratar-se de uma espécie predominantemente de cruzamento, portanto provavelmente contém uma certa carga genética (Sorensen \& White, 1988), é possível que muitas sementes constituídas de genes recessivos letais ou homozigóticos deletérios tenham sido eliminados por aborto antes da germinação ou morrido durante a fase de viveiro, ou nos primeiros anos de plantio, levando a subestimativas nas taxas de autofecundações. Provavelmente a causa da alta mortalidade nos ensaios (20,9\% em Pederneiras e 14,3\% em Luiz Antonio) tenha, em parte, esta mesma origem, a depressão por endogamia. Estudos sobre a depressão por endogamia em essências florestais têm mostrado altas taxas atuando antes e após a germinação das sementes. Tem sido verificado que progênies de autofecundação apresentam taxas de mortalidade maiores do que progênies de cruzamento (Sorensen \& Miles, 1982; Griffin \& Cotterill, 1988; Durel et al., 1990; Kärkkäinen \& Savolainen, 1993; Hardner \& Potts, 1997). Em alguns estudos também foram observados que a depressão por endogamia varia entre populações de uma mesma espécie (Kărkkäinen et al., 1996; Hardner \& Potts, 1997), além de sua herança poder ter diferentes origens, indo desde a expressão de genes detrimentais (letais e deletérios) a efeitos gênicos de dominância. Entre outros efeitos, a depressão por endogamia pode causar o aumento na taxa de mortalidade e a má formação e redução no crescimento (Charlesworth \& Charlesworth, 1987; Mitton et al., 1989; Crow, 1993; Lande et al., 1994; Koelewijn et al. 1996; Koelewijn et al. 1999). Desta forma, a mortalidade não aleatória de sementes de 
autofecundação e de cruzamentos entre aparentados, poderiam ter causado superestimativas nas taxas de cruzamentos multilocos.

Outra hipótese que poderia explicar as altas taxas de cruzamentos, é a presença de mecanismos de auto-incompatibilidade na espécie. Estudos de Murawski (1995), têm mostrado que $90,9 \%$ das espécies arbóreas tropicais que ocorrem no extrato superior do dossel, 75,0 \% das espécies do extrato intermediário e 34,2\% das espécies de sub-bosque, apresentam algum mecanismo de auto-incompatibilidade. Já, de acordo com Bawa et al. (1985), a maioria das espécies tropicais hermafroditas, como $C$. legalis e de baixas altitudes apresentam fortes barreiras para autofecundação. Assim, a maior parte da autofecundação detectada nas análises individuais das progênies (Tabela 24) poderia ser, na verdade, cruzamentos entre aparentados. $O$ modelo utilizado para caracterizar a taxa de cruzamento, modelo de reprodução mista, nas análises individuais por planta materna, não separa a taxa de autofecundação das taxas de cruzamentos entre aparentados. Outra acausa, ainda, poderia ser atribuida a erros de amostragem. Entretanto, estas hipóteses não podem ser confirmadas neste trabalho, dado que não foi realizado nenhum acompanhamento da fenologia do florescimento, germinação e desenvolvimento das plantas na fase de viveiro. Contudo, é importante ressaltar que estas barreiras para a autofecundação não ocorrem obrigatoriamente em todos os individuos e durante todo o período de florescimento, podendo ter origem genética e ocorrer apenas em fases específicas do florescimento, portanto, a sua presença não é $100 \%$ efetiva. Além disso, a grande maioria das espécies arbóreas tropicais que tiveram sua taxa de cruzamento determinada (ver Tabela 49), revelaram-se como de cruzamento misto, logo contrariando em parte as observações de Murawski (1995).

Apesar das elevadas taxas de cruzamentos detectadas nas populações, o teste de Equilibrio de Hardy-Weinberg (EHW) e o teste de homogeneidade nas frequências alélicas dos óvulos e do pólen mostraram desvios de cruzamentos aleatórios, embora as estimativas de $\hat{t}_{p}$ terem detectado cruzamentos entre aparentados (mínimo 5,9\%). Os desvios de cruzamentos aleatórios foram causados, segundo os locos submetidos ao teste de EEW, pelo sistema reprodutivo, mais especificamente devido ao cruzamento entre indivíduos aparentados combinados com cruzamentos preferenciais. Em concordância, a 
estimativa da correlação de $p\left(\hat{r}_{p}\right)$ ou a probabilidade de detectar irmãos completos dentro das progênies, foi expressiva $(>0,212)$, e a heterogeneidade entre o conjunto gênico materno e paterno indica que o pólen não foi homogêneo para o cruzamento individual das árvores maternas, confirmando a hipótese de cruzamentos preferenciais nas populaçōes. Assim, as progênies de polinização aberta de $C$. legalis não são compostas exclusivamente por meios irmãos, como era esperado se as populações fossem infinitamente grandes e os cruzamentos aleatórios (populaçð̌es panmiticas), mas também por irmãos completos e plantas de autofecundação. Desvios da pressuposição de panmixia, em testes de progênies de polinização aberta podem gerar superestimativas na variância genética aditiva, herdabilidades e ganhos preditos na seleção (Namkoong, 1966; Squillace, 1974; Surles et al., 1990), pela sua distribuição incorreta entre e dentro de progênies, em relação ao esperado para o modelo exclusivo de meios irmãos $\left(1 / 4 \hat{\sigma}_{A}^{2}\right.$ entre e $3 / 4 \hat{\sigma}_{A}^{2}$ dentro de progênies). Por sua vez, a presença de cruzamentos entre aparentados diminui a variância genética aditiva entre progênies e aumenta dentro de progênies, ou seja, aumenta a covariância genética entre indivíduos dentro de progênies.

As taxas de cruzamentos entre aparentados $\left(\hat{t}_{p}\right)$, apesar de baixas (máximo 9,1 \%), foram significativas, sugerindo que esta forma de reprodução gera um certo nível de endogamia nas populações a cada evento reprodutivo e que existe parentescos nas populações naturais, como já comentado. Os cruzamentos entre aparentados aumenta a quantidade de homozigotos nas populações, apesar de ser uma forma menos drástica de produzir endogamia, do que a autofecundação, mas não exclui a possibilidade de gerar depressão por endogamia, pela expressão de genes recessivos deletérios (Crow \& Kimura, 1970; Ellstrand \& Elam, 1993). O maior problema desta forma de reprodução encontra-se na conservação in situ de populações pequenas ( $<100$ indivíduos) e fragmentadas, como é o caso da população Campinas e Ibicatu, com 17 e 16 individuos, respectivamente. Nestas, o tamanho senso já está abaixo do tamanho efetivo mínimo aceitável para a conservação in situ $\left(\hat{N}_{e}=50\right)$, o que pode levá-las a perderem alelos raros (freqüência menor que $5 \%$ ) por deriva genética, em poucas gerações (Frankel \& Soulé, 1981). O quadro agrava-se quando se consideram que foram detectados cruzamentos entre 
indivíduos aparentados dentro das populações, como já discutido, portanto, o tamanho efetivo real deve ser ainda menor do que o número de exemplares (Campinas 17 e Ibicatu 16). A estratégia de conservação, neste caso, deve ser a do manejo de reposição, aumentando o tamanho destas populações para pelo menos 100 indivíduos. A reposição deve ser feita através da coleta de sementes de outras populações, como por exemplo, da população Vassununga, a qual apresenta aproximadamente 300 indivíduos adultos reprodutivos. $\mathrm{O}$ aumento do tamanho populacional poderá melhorar outros aspectos do sistema de reprodução da espécie, como reduzir os cruzamentos preferenciais e a autofecundação e aumentar a aleatoriedade dos cruzamentos, pela alteração no comportamento dos polinizadores, como sugerido por Murawski (1995).

Levando em conta a amostragem de sementes em todas as plantas na população Campinas e Ibicatu e o número de indivíduos representando cada planta materna no ensaio (entre 30 a 60 plantas, considerando os dois locais), acredita-se que o conjunto gênico destas populações esteja preservado nos bancos de conservação ex situ.

A constatação de que os ensaios são compostos em grande parte por plantas advindas de cruzamentos, pressupõe alta heterozigosidade e potencial para o melhoramento genético. A seleção dos melhores indivíduos/progênies/populações, permite transformar os ensaios em pomares de sementes por mudas e em populações base de recombinação para um programa de melhoramento com a espécie. A recombinação das plantas selecionadas de diferentes populações (total de 55 progênies), pode ampliar a base genética das populações originais, dando origem a uma nova população, com tamanho efetivo que permita submeter a $C$. Legalis a um programa de seleção. Contudo, os resultados mostraram que a seleção para produtividade não pode ser baseada nos modelos clássicos de genética quantitativa, aplicados para espécie exchusivamente alógamas. Tais modelos pressupõem cruzamentos aleatórios, ausência de endogamia e parentesco na geração parental $(\hat{f}=\hat{\theta}=0)$ e progênies de polinização aberta, compostas exclusivamente por meios irmãos. Desvios destas pressuposições levam à superestimativas de ganhos genéticos. Para tanto, deve-se optar por modelos que considerem o sistema misto de reprodução, como por exemplo, o modelo sugerido por Cockerham \& Weir (1984) ou Ritland (1989), para estas situações. 


\subsection{CRescimento dos CaRaCteres nas PopulaÇões}

Os coeficientes de variação experimental $\left(\mathrm{CV}_{\text {exp }}\right)$ foram baixos $(<18 \%)$ para os caracteres FF, DAP e ALT, médios para SOB (23 a 32\%) e altos para o VC ( $>37 \%$ ), sugerindo maior precisão nas estimativas de componentes de variância e parâmetros genéticos nos três primeiros caracteres (Tabela 25). O caráter $\mathrm{VC}$, de modo geral, apresenta altos $\mathrm{CV}_{\exp }$, por tratar-se de um caráter estimado a partir de dois outros (DAP e da altura), o que leva ao acúmulo dos erros existentes nestes caracteres. Os médios e altos $\mathrm{CV}_{\text {exp }}$ podem também ter sido causados pela mortalidade não aleatória nas sub-parcelas, diferentes graus de endogamia nas progênies e/ou serem inerentes à própria variação fenotípica da espécie.

O crescimento médio $(\bar{x})$ e o incremento médio anual (IMA) dos caracteres apresentaram melhor desempenho em Luiz Antonio (Tabela 25). As médias entre populações dos caracteres FF, DAP, ALT, VC e SOB em Luiz Antonio, foram 11,0, 6,8, $32,0,64,3$ e 8,3\%, respectivamente, superiores às encontradas em Pederneiras. Estas diferenças são atribuídas principalmente à melhor fertilidade do solo de Luiz Antonio (Latossolo Roxo) e à desrama realizada neste plantio aos 8 anos de experimentação. A espécie prefere solos férteis (Nogueira, 1977), o que favorece o crescimento e adaptação às condições de Luiz Antonio. A desrama certamente também favoreceu o crescimento, pela translocação de energia dos galhos laterais, retirados, para a parte superior da copa das árvores. Assim, atribui-se as diferenças nos crescimentos entre locais, principalmente, a fatores ambientais.

Apesar das diferenças nos crescimentos dos caracteres entre locais, a população Campinas apresentou o melhor desempenho para todos os caracteres nos dois locais de ensaio, exceção apenas para SOB em Luiz Antonio, onde a população Vassununga teve maior sobrevivência. Em Luiz Antonio, em segundo lugar na classificação, ficou a população Vassununga e em Pederneiras a população Ibicatu. Vale lembrar que a população Vassununga localiza-se mais próxima de Luiz Antonio $(30 \mathrm{~km})$ e a população Ibicatu mais próxima de Pederneiras $(200 \mathrm{~km})$. Verifica-se também, que as diferenças nos crescimentos entre populações foram maiores em Pederneiras revelando diferenças de até $28,5 \%$ para VC entre a população de melhor e pior desempenho (Campinas e Ibicatu, 
respectivamente). De modo geral, estes resultados sugerem que a população Campinas apresenta maior plasticidade fenotípica, adaptando-se bem a ambos locais de ensaio.

O IMA aos 17 anos para o DAP em Luiz Antonio $(0,79 \mathrm{~cm})$ foi semelhante ao apresentado por Carvalho (1994) para C. legalis aos 22 anos de idade, plantada em Latossolo Roxo, em Cosmópolis, SP $(0,79 \mathrm{~cm})$, porém $13,2 \%$ inferior ao encontrado pelo autor para a altura. As diferenças em altura podem ser associadas às diferenças na idade, espaçamentos ou tratos culturais adotados nos ensaios. Infelizmente, Carvalho (1994) não menciona o espaçamento utilizado nem faz inferências sobre os tratos culturais realizados, dificultado a comparação.

Tabela 25. Médias de crescimentos dos caracteres forma do fuste (FF), DAP, altura (ALT), volume cilíndrico (VC) e sobrevivência (SOB) para as populações, médias de locais e incremento médio anual (IMA), para Luiz Antonio (LA), Pederneiras (PE) e análise conjunta (CONJ) em C. legalis.

\begin{tabular}{|c|c|c|c|c|c|c|}
\hline & População & $\mathrm{FF}$ & DAP $(\mathrm{cm})$ & ALT (m) & $\mathrm{VC}\left(\mathrm{m}^{3} / \mathrm{ha}\right)$ & SOB (\%) \\
\hline \multirow{6}{*}{ LA } & Campinas & 1,95 & 14,20 & 12,62 & 420,49 & 86,3 \\
\hline & Ibicatu & 1,90 & 13,07 & 11,72 & 354,75 & 81,4 \\
\hline & Vassununga & 1,92 & 13,18 & 12,41 & 372,69 & 89,2 \\
\hline & Média $(\bar{x})$ & 1,92 & 13,49 & 12,26 & 383,41 & 85,7 \\
\hline & IMA & $\ldots$ & 0,79 & 0,72 & 22,55 & -- \\
\hline & $C V_{\text {exp }}(\%)$ & 8,8 & 17,7 & 14,2 & 44,7 & 31,4 \\
\hline \multirow{6}{*}{$\mathrm{PE}$} & Campinas & 1,88 & 13,78 & 11,11 & 340,07 & 83,3 \\
\hline & Ibicatu & 1,82 & 12,90 & 10,54 & 288,39 & 80,6 \\
\hline & Vassununga & 1,79 & 12,62 & 10,70 & 285,06 & 74,7 \\
\hline & $\operatorname{Média}(\bar{x})$ & $1, \overline{83}$ & 13,11 & 10,79 & 304,28 & 79,1 \\
\hline & IMA & --- & 0,77 & 0,63 & 17,99 & $\cdots$ \\
\hline & $C V_{\exp }(\%)$ & 8,7 & 15,5 & 12,4 & 37,5 & 23,0 \\
\hline \multirow{6}{*}{ CONJ } & Campinas & 1,88 & 13,78 & 11,11 & 340,07 & 84,8 \\
\hline & Ibicatu & 1,82 & 12,90 & 10,54 & 288,39 & 81,0 \\
\hline & Vassununga & 1,79 & 12,62 & 10,70 & 285,06 & 81,9 \\
\hline & Média $(\bar{x})$ & 1,83 & 13,11 & 10,79 & 304,28 & $82, \overline{8}$ \\
\hline & MA & -- & 0,77 & 0,63 & 17,99 & - \\
\hline & $C V_{\exp }(\%)$ & 8,6 & 16,7 & 13,6 & 43,8 & 27,4 \\
\hline
\end{tabular}

Comparando os IMA em DAP e altura com os encontrados por Sebbenn et al. (2000) analisando este mesmo ensaio aos 4, 6, 11 e 14 anos de idade (Tabela 26), 
verifica-se que o crescimento vem diminuindo sensivelmente com a maturação das árvores, porém, ainda, encontram-se em pleno desenvolvimento, como pode ser observado pela magnitude dos IMA obtida na análise conjunta aos 17 anos de idade $(0,77$ $\mathrm{cm}$ para DAP e 0,63 m para altura).

Tabela 26. Incremento médio anual (IMA) para DAP e altura de C. legalis, em várias idades de crescimento.

\begin{tabular}{|c|c|c|c|c|c|c|c|c|c|}
\hline & \multicolumn{5}{|c|}{ Altura (m) } & \multicolumn{4}{|c|}{$\operatorname{DAP}(\mathrm{cm})$} \\
\hline Local & 4 anos & 6 anos & 11 anos & 14 anos & 17 anos $^{4}$ & 6 anos & 11 anos & 14 anos & 17 anos $^{*}$ \\
\hline LA & 0,91 & 0,86 & 0,74 & 0,73 & 0,72 & 1,00 & 0,84 & 0,80 & 0,79 \\
\hline $\mathrm{PE}$ & 0,94 & 0,87 & 0,74 & 0,74 & 0,55 & 0,90 & 0,86 & 0,81 & 0,74 \\
\hline
\end{tabular}

LA: Luiz Antonio; PE: Pedemeiras; Dados aos 4, 6, 11 e 14 anos, compilados de Sebbenn, et al., (2000); a: Dados deste estudo.

A sobrevivência (Tabela 25 ) foi alta nas populações (mínimo $74 \%$ na população Vassununga em Pederneiras) sugerindo uma boa adaptação da espécie aos locais de experimentação. Entre populações, também se verificam poucas diferenças nas sobrevivências, sendo contudo, maiores na população Campinas. É provável que a sobrevivência esteja sobre controle genético. Em espécies de reprodução mista, mesmo pequenas taxas de autofecundação (5\%) são suficientes para o aparecimento de combinações gênicas desfavoráveis (homozigose para genes deletérios ou letais). Estudos sobre endogamia em essências florestais têm mostrado ao longo de $\mathbf{3 0}$ anos de pesquisa, que a depressão por endogamia é severa para os caracteres de crescimento. A depressão por endogamia tem provavelmente uma grande importância evolutiva para as populações destas espécies, reduzindo a carga genética pela eliminação de genes recessivos letais e deletérios a cada evento reprodutivo e diminuíndo por sua vez, os efeitos detrimentais causados pelas mutações negativas. Estudos deste tipo também têm mostrado que estes genes podem atuar em diferentes fases de desenvolvimento das plantas e estarem distribuídos de forma diferenciada entre populações de uma espécie, logo, as populações podem apresentar diferenças na carga genética. Aqui no caso, a mortalidade observada pode ter sido em parte causada por estes genes. Esta hipótese parece plausível quando comparamos a taxa de autofecundação (Tabela 23) com a taxa de sobrevivência 
populacional média entre locais (Tabela 25). Verifica-se que a população de menor taxa de autofecundação, Campinas, apresentou a maior sobrevivência, sendo que as outras populações apresentaram maiores taxas de autofecundação e mortalidades.

Em termos médios, os resultados dos crescimentos e da sobrevivência mostraram uma boa adaptação da espécie aos dois locais de ensaio, em especial à Luiz Antonio.

\subsection{ESTRUTURA GENÉTICA}

O termo "estrutura genética de populações" será aqui utilizado como sinônimo da distribuição da variabilidade genética entre e dentro das populaçōes. A estrutura genética das populações de $C$. legalis foi analisada por caracteres quantitativos e por isoenzimas. Os resultados das análises da variância individual e conjunta para locais encontram-se nas Tabelas 28 a 30, em anexo (Tabelas 54 a 57).

\subsubsection{Caracteres Quantitativos}

As maiores divergências entre populações $\left(\hat{\theta}_{P}{ }^{\prime}\right)$ foram observadas em Pederneiras para os caracteres $\mathrm{FF}$ e VC, evidenciando que 36,8 e $66,1 \%$ da variabilidade genética encontrava-se entre populações, respectivamente (Tabela 27). Já na análise conjunta dos locais, a divergência entre populações destes caracteres reduziu-se para $6,0 \mathrm{e}$ 12,8\%, respectivamente. Apesar da magnitude da divergência genética entre populações, os testes $\mathrm{F}$ das análises da variância individual e conjunta para locais não revelaram diferenças genéticas significativas entre populaçốes para os cinco caracteres avaliados, com exceção do FF em Pederneiras. Estudos da estrutura genética de populações de essências florestais a partir de caracteres quantitativos têm revelado resultados similares. Hamrick (1970) estudando a distribuição da variabilidade genética em quatro populações naturais de Abies concolor encontrou em 13 caracteres quantitativos, diferenças entre populações variando de 0,0 a $49,8 \%$, com média de $20 \%$. Moraes (1993) avalianado a estrutura genética de duas populações de Myracrodruon urundeuva para 14 caracteres quantitativos detectou no máximo $2,6 \%$ (porcentagem de fósforo) de divergência genética entre populações, sendo que, na média, os caracteres não apresentaram diferenças entre populações. Sebbenn et al. (1999a) analisando a estrutura genética de sete procedências 


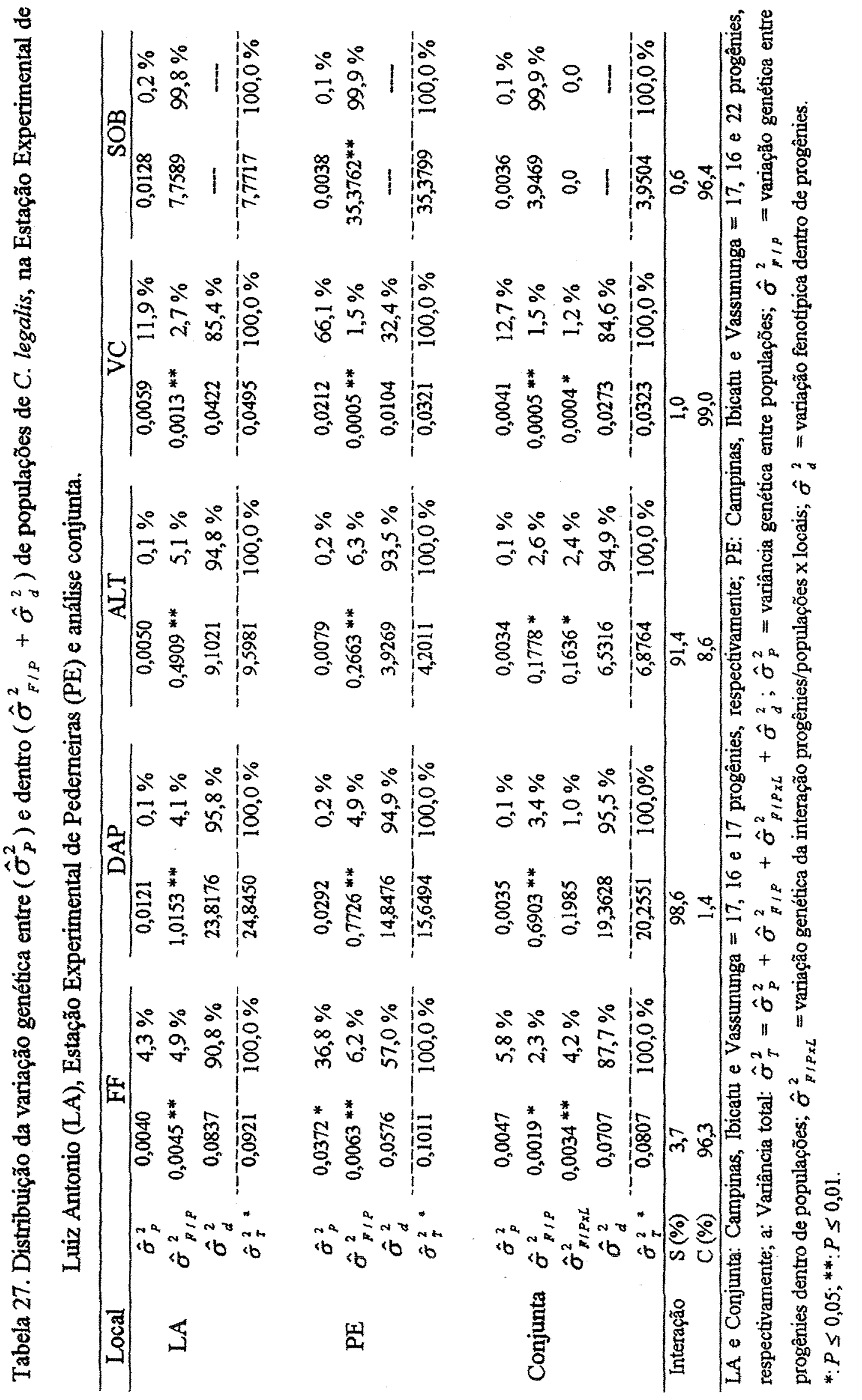


de Grevillea robusta para os caracteres DAP e altura, em três locais de ensaio, detectaram diferenças entre populações, variando de 1,0 a $20 \%$. Siqueira et al. (2000) caracterizando populações de Balfourodendruon riadelianum detectaram no máximo $3,2 \%$ de divergência genética entre populações a partir dos caracteres DAP e altura. Como se pode observar, todos estes trabalhos têm revelado maior variabilidade dentro de populações, porém a magnitude da divergência genética entre populações parece depender do tipo de caráter usado para estudar a estrutura genética populacional. Também o número de populações amostradas para o estudo da estrutura populacional parece influenciar a magnitude da divergência genética entre populações. Na Tabela 1, observa-se que trabalhos que incluem maior número de populações tendem a apresentar maiores divergências entre populações. Por exemplo, Kehlet \& Roulund (1995) estudando 14 populações de Picea stchansis e Khalil (1985) estudando 9 populações de Picea mariana, observaram que mais de $50 \%$ da variabilidade genética estava entre populações. Portanto, a ausência de diferenças genéticas entre populações de C. legalis, para a maioria dos caracteres, indica que a estratégia de amostragem para a conservação ex situ não foi suficiente para representar a variabilidade existente entre populações da espécie ou, que realmente não existe. Possivelmente, o número de três populações seja insuficiente para detectar grandes diferenças genéticas entre populações e reter-se, nos bancos de conservação, a provável variação genética existente entre populações, ainda mais considerando que estas populações habitam regiões próximas (região central do Estado de São Paulo), não representativas da distribuição ecogeográfica da espécie. Neste caso, é importante para a efetiva conservação de $C$. legalis, a amostragem de populações representativas de toda a sua distribuição natural e não só do Estado de São Paulo.

Tendo em vista que os testes de progênies permitem avaliar os progenitores a partir de seus descendentes, os resultados aqui apresentados permitem inferir sobre as populações naturais de onde o material foi coletado. Assim, em relação à conservação in situ, os resultados sugerem que estas populações são semelhantes do ponto de vista genético. A semelhança pode ser explicada por duas hipóteses: primeiro, devido a uma origem comum, ou seja, as três populaçð̃es poderiam ter sido fundadas de uma mesma população ancestral; segundo, devido ao intenso fluxo gênico ocorrido no passado, 
quando as florestas do Estado de São Paulo eram contínuas, levando à homogeneidade na variabilidade genética das populações. Como se trata de uma espécie longeva (vive mais do que 500 anos - Carvalho, 1994) e o processo de fragmentação é recente (menos de 100 anos), não transcorreu tempo suficiente para que ocorresse grande divergência genética entre populações por deriva genética e/ou seleção natural.

A variabilidade genética entre progênies/populações $\left(\hat{\sigma}_{F / P}^{2}\right)$ foi baixa, mas significativa pelo teste $F(1 \%$ ), variando de 1,5 a $6,2 \%$ entre os caracteres e a variabilidade fenotípica dentro de progênies $\left(\hat{\sigma}_{d}^{2}\right)$ foi alta para todos os caracteres, com valores, em muitos casos, acima de $90,0 \%$. Só não foram detectadas diferenças genéticas entre progênies/populações para o caráter SOB em Luiz Antonio e na análise conjunta. Neste caso, a ausência de variabilidade genética foi decorrente da menor mortalidade no ensaio de Luiz Antonio, bem como a aleatoriedade destas dentro das progênies.

A maior variação dentro de progênies tem sido detectada em todos os trabalhos de estrutura populacional com caracteres quantitativos (Hamrick, 1976; Sorensen \& White, 1988; Moraes, 1993; Sebbenn et al., 1999; Siqueira et al., 2000). Apesar de se tratar de variação fenotípica, este componente contém $3 / 4$ da variância genética aditiva em progênies de meios irmãos e $1 / 2$ em progênies de irmãos completos, portanto, no mínimo $50 \%$ de variabilidade genética herdável em espécies de cruzamento. Todavia, levando em conta que as progênies representam misturas de diferentes proporções de meios irmãos, irmãos completos e indivíduos de autofecundação, sendo os dois últimos grupos de menor proporção, pode-se pressupor que a variância genética aditiva dentro das progênies esteja entre os limites de $3 / 4$ (meios irmãos) e $1 / 2$ (irmãos completos). Esta mistura de diferentes parentescos nas progênies possivelmente foi a causa da alta $\hat{\sigma}_{d}^{2}$ nas populações. A variância genética dentro de progênies exclusivamente de meios irmãos possui um componente genético aditivo e um componente de dominância $\left(\hat{\sigma}_{g(\text { dentro })}^{2}=3 / 4 \hat{\sigma}_{A}^{2}+\right.$ $\left.1,0 \hat{\sigma}_{D}^{2}\right)$. A mistura de meios irmãos e irmãos completos nas progênies diminui estes componentes dentro de progênies e aumenta entre progênies, para valores intermediários entre meios irmãos e irmãos completos $\left(\hat{\sigma}_{g \text { (entre })}^{2}=1 / 2 \hat{\sigma}_{A}^{2}+1 / 4 \hat{\sigma}_{D}^{2} ; \hat{\sigma}_{g(\text { densro })}^{2}=\right.$ $1 / 2 \hat{\sigma}_{A}^{2}+3 / 4 \hat{\sigma}_{D}^{2}$ ). Já, a mistura simultânea de meios irmãos, irmãos completos e 
indivíduos de autofecundação, dentro das progênies, além de redistribuir a $\hat{\sigma}_{A}^{2}$ e $\hat{\sigma}_{D}^{2}$, incorpora outros componentes a variância genética entre e dentro de progênies, como a covariância dos efeitos aditivos e de dominância $\left(D_{1}\right)$, variância nos efeitos de dominância dos homozigotos $\left(D_{2}\right)$, soma dos quadrados dos efeitos da endogamia $(H)$ e quadrado das somas dos efeitos da endogamia $\left(H^{2}\right)$, sendo que os dois últimos termos citados traduzemse em efeitos da depressão por endogamia. A depressão por endogamia, quando expressa em ensaios de campo, pode levar à maior variação fenotípica dentro de progênies e mascarar a variabilidade genética entre progênies e entre populações. Estudos têm mostrado que progênies de autofecundaçao apresentam maior variação fenotípica dentro de progênies do que progênies de cruzamento (Sniezko \& Zobel, 1988; Sorensen \& White, 1988; Geburek, 1986; Hardner \& Potts, 1995; Matheson et al., 1995; Wu et al., 1998). Esta pode ter sido a causa da baixa variabilidade genética detectada entre progênies/populações, pela presença de correlações intraclasses, onde os indivíduos de diferentes progênies são fenotipicamente mais parecidos entre si do que dentro das progênies. Por sua vez, a alta variação fenotípica dentro de progênies pode ter dificultado a discriminação entre populações, já que a mistura de diferentes relações de parentesco dentro das progênies ocorreu igualmente nas três populações. A depressão por endogamia é um dos maiores problemas da utilização de progênies de polinização aberta para a estimativa de parâmetros genéticos, combinado com a coleta de sementes em populações naturais, onde, muitas vêzes, existe uma estruturação intema em grupos de famílias, com diferentes graus de parentesco, históricos de endogamia e desvios do Equilibrio de HardyWeinberg (EHW). Isto aumenta ainda mais a covariância dentro de progênies, portanto, também a probabilidade de genes detrimentais (letais e deletérios) se combinam em homozigose nas populações.

Para fins de melhoramento genético, a ausência de divergência genética entre populações demonstra que não existe vantagens na seleção de uma ou outra população para servir de base a um programa de melhoramento com a espécie. Desta forma, é possível tratar-se as três populações como uma só, com a vantagem de ampliar a base genética da população base, pela baixa probabilidade de existência de parentesco entre progênies de diferentes populações. A seleção deve ser direcionada a explorar a 
variabilidade genética entre e dentro de progênies/populações e a recombinação dos melhores indivíduos de cada população realizada desconsiderando o efeito de populações. Assim, as melhores plantas das três populações estarão se recombinando, aumentando o tamanho efetivo da população selecionada.

\subsubsection{Dados de Isoenzimas}

As frequêencias alélicas estimadas para as progênies não representam obrigatoriamente as freqũências dos individuos adultos nas populações naturais, de onde foram originadas. A amostragem de progênies de polinização aberta determina que as freqüências alélicas sejam dominadas pelas freqüências das árvores maternas, sendo a contribuição dos alelos de origem paterna menor para as freqüência alélicas das progênies. Então, para inferir sobre as freqüências alelicas das populações naturais é necessário separar as frequências de origem materna das de origem paterna. A separação das freqüências alélicas de origem materna e paterna foi realizada pelas estimativas de máxima verossimilhança dos óvulos e do pólen (Ritland \& Jain, 1981). As freqüências dos óvulos foram escolhidas para representar os individuos adultos nas populações naturais porque se desconhece o número real de polinizadores.

A divergência genética entre populações (Tabela 28$)$ foi baixa para adultos $(2,3 \%)$ e progênies $(0,9 \%)$, indicando similaridade genética entre populações, em concordância aos resultados obtidos para os caracteres quantitativos. $O$ alto fluxo gênico aparente estimado entre populações confirma esta hipótese (Tabela 28). Porém, a baixa diferenciação entre populações não ocorreu pelo fluxo gênico atual, dado que é pouco provável que ele exista ou que seja intenso o suficiente para manter estas populações coesas do ponto de vista genético, pela grande distância que separa os fragmentos (mínimo de $100 \mathrm{~km}$, entre a população Ibicatu e Campinas). Logo, as estimativas obtidas de fluxo gênico representam um acontecimento passado, antes do processo de fragmentação e a baixa diferenciação genética reflete a divergência genética que existia antes do processo de exploração, ou seja, baixa diferenciação. 
Tabela 28. Divergência genética e fhuxo gênico entre populações de $C$. legalis.

\begin{tabular}{lccc}
\hline \multicolumn{1}{c}{ Populações } & $\begin{array}{c}\text { Distância média } \\
\text { aproximada }\end{array}$ & $\hat{\theta} \hat{p}$ & $\hat{N} m$ \\
\hline Progênies - SP & $180 \mathrm{~km}$ & $0,009(-0,004 \mathrm{a} 0,028)$ & 13,8 \\
Adultos - SP & $180 \mathrm{~km}$ & $0,023(0,015 \mathrm{a} 0,031)^{\mathrm{ab}}$ & 2,6 \\
Adultos - ES & $<30 \mathrm{~km}$ & $0,052(0,007 \mathrm{a} 0,126)$ & 1,1 \\
Conjunta SP e ES (Adultos) $^{\mathrm{c}}$ & $>800 \mathrm{~km}-$ & $0,093(-0,217 \mathrm{a} 0,403)^{\mathrm{ab}}$ & 1,6 \\
\hline
\end{tabular}

(): Intervalo de confiança à $95 \%$ de probabilidade, estimado a partir de 10.000 reamostragens bootstrap sobre locos; a: Estimativa $\hat{F}_{5 T}$ (Nei, 1977) realizada apenas utilizando os locos $\alpha$ Est-1, $\alpha$ Est-2, Mdh-1 e Pgi-1; b: Intervalo de confiança à $95 \%$ de probabilidade, estimado a partir de reamostragem Jeckknif sobre locos; c: Três populaçōes de São Paulo e duas do Espírito Santo; e: Harrit (1991).

A maioria dos estudos de estrutura genética de populações de espécies arbóreas alógamas, realizados a partir de dados de isoenzimas, tem apresentado baixa divergência entre populações (Hamrick \& Godt, 1990). Harritt (1991), estudando duas populações de C. legalis no Estado do Espírito Santo, encontrou aproximadamente 5,2\% de divergência genética entre populações.

Comparando-se todas as populações a partir dos indivíduos adultos do Estado de São Paulo com as do Espírito Santo (Tabela 28), observa-se que a divergência genética aumenta consideravelmente conforme aumenta a distância entre as populações $(9,3 \%)$, sugerindo a hipótese de isolamento por distância. Neste caso, a divergência pode ser atribuída principalmente à deriva genética ocorrida durante o evento de colonização, se considerarmos a natureza supostamente neutra do marcador usado. Todavia, como as populações em estudo encontram-se isoladas, pode-se prever um aumento na divergência genética com o passar das gerações. Espera-se menos problemas de deriva e endogamia na população Vassununga, inclusive considerando a maior taxa de autofecundação (10\%), devido ao maior número de indivíduos e área disponível para sua regeneração (área $\cong$ 191,0 ha). A autofecundação possivelmente será compensada pela seleção contra homozigotos. No caso das populações Campinas e Ibicatu, a situação complica-se pelos seguintes fatores: primeiro, o número de indivíduos nestas está abaixo do tamanho efetivo mínimo (50) para que não ocorra a perda de alelos raros por deriva em poucas gerações (Frankel \& Soulé, 1981); segundo, a área disponível para a regeneração natural é restrita, em especial para a população Campinas, que é um parque público, submetido à 
jardinagem e limpezas periódicas, portanto, reduzindo as chances do recrutamento de novos indivíduos. Nestes casos, para a perpetuação das populações será necessária a reintrodução de novos indivíduos, caso contrário, provavelmente elas irão desaparecer quando da morte dos exemplares existentes.

Uma outra informação importante fornecida pelas medidas de divergência genética entre populações $\left(\hat{F}_{S T}\right.$ e $\left.\hat{\theta}_{p}\right)$ é o parentesco dentro das populações naturais. Considerando que estas estatísticas medem o grau de divergência genética entre populações, a partir da correlação genética entre indivíduos dentro de populações, portanto a partir da probabilidade de que dois alelos tomados em dois indivíduos de uma mesma população sejam idênticos por descendência, tem-se o parentesco médio dentro das populações. Aqui no caso, o $\hat{F}_{S T}$ dá o parentesco médio entre árvores maternas e $\hat{\theta}_{p}$ o parentesco médio entre todos os progenitores que deram origem às progênies, logo, mede o parentesco das árvores maternas e paternas, simultaneamente. Nota-se assim, que o parentesco médio entre as árvores maternas é de 2,3\% e entre árvores maternas e paternas de $0,9 \%$. A redução no grau de parentesco, quando progenitores masculinos e femininos são considerados na estimativa, parece coerente, dado que o número de plantas das populações incluídas na análise aumenta, e o parentesco pode diminuir. Este resultado está de acordo com as observações do sistema de reprodução, que também detectaram a presença de cruzamentos entre parentes dentro das populações (mínimo 5,9\%).

Pode-se também inferir sobre o parentesco dentro das populações, a partir da taxa de autofecundação. Mas neste caso, é necessário admitir equilibrio de endogamia. Em equilibrio de endogamia o coeficiente de endogamia dos filhos é igual ao coeficiente de parentesco dos progenitores (Squillace, 1974; Lindgren \& Mullin, 1997), então:

$$
\hat{f}_{\text {prog. }}=\hat{\theta}_{\text {Parentats }}=\frac{s}{2-s}
$$

A partir disso, tem-se que o parentesco na população Campinas é de $0,05 \%$, Ibicatu de $1,2 \%$ e Vassununga de $5,2 \%$, resultando em um valor médio entre populações de $2,1 \%$, muito próximo ao obtido para as plantas maternas (2,3\%). Este parentesco tem implicações importantes na estimativa de herdabilidades e ganhos genéticos. Segundo 
Squillace (1974), a presença de parentesco na geração parental pode causar subestimativas nas herdabilidades e ganhos na seleção.

A variabilidade entre progênies dentro de populações $\left(\hat{\theta}_{F}\right)$ variou de 13,1 a 15,5\% (Tabela 29). Seguindo o mesmo raciocínio utilizado para quantificar o parentesco médio dentro das populações, o $\hat{\theta}_{F}$ dá uma idéia do parentesco existente dentro das progênies. Em progênies de meios irmãos o valor mínimo esperado para $\hat{\theta}_{F}$ é de 0,125 , contudo, na presença de misturas de progênies de meios irmãos, irmãos completos e de indivíduos de diferentes graus de autofecundação (F1, F2, etc), seu valor sobe em direção à 0,5 , sendo tanto mais próximo deste quanto maior for o parentesco dentro das progênies. No caso, a análise do sistema reprodutivo revelou que as progênies não são exclusivamente de meios irmãos, como já discutido, existindo também uma certa proporção de irmãos completos e de indivíduos de autofecundação.

Tabela 29. Componentes de variância, coeficientes de coancestralidade e indices de fixação $(\hat{f}$ e $\hat{F}$ ) para análise individual e conjunta das populações de $C$. legalis.

\begin{tabular}{|c|c|c|c|c|c|c|c|c|}
\hline & \multicolumn{2}{|c|}{ Pop. Campinas } & \multicolumn{2}{|c|}{ Pop. Ibicatu } & \multicolumn{2}{|c|}{ Pop. Vassununga } & \multicolumn{2}{|c|}{ Conjunto } \\
\hline \multirow{5}{*}{$\begin{array}{c}\hat{\sigma}_{P}^{2} \\
\hat{\sigma}_{p}^{2}{ }_{1 P}^{2} \\
\hat{\sigma}_{1 P}^{2} \\
\hat{\sigma}_{Q / P}^{2} \\
\hat{\sigma}_{T}^{2} \\
\end{array}$} & - & - & - & - & - & - & 0,0407 & $0,9 \%^{\mathrm{a}}$ \\
\hline & 0,6088 & $13,1 \%^{b}$ & 0,5559 & $14,8 \%^{b}$ & 0,7601 & $15,5 \%^{\mathrm{b}}$ & 0,6490 & $13,9 \%^{b}$ \\
\hline & 0,6065 & $13,1 \%$ & 0,4822 & $12,8 \%$ & 0,3834 & $7,8 \%$ & 0,4718 & $10,1 \%$ \\
\hline & 3,4292 & $73,8 \%$ & 2,7263 & $72,4 \%$ & 3,7467 & $76,6 \%$ & 3,5008 & $75,1 \%$ \\
\hline & 4,6445 & $100,0 \%$ & 3,7644 & $100,0 \%$ & 4,8902 & $100,0 \%$ & 4,6623 & $100,0 \%$ \\
\hline$\hat{f}$ & \multicolumn{2}{|c|}{$\begin{array}{c}0,150 \\
(0,050 \mathrm{a} 0,241)\end{array}$} & \multicolumn{2}{|c|}{$\begin{array}{c}0,150 \\
(0,090 \mathrm{a} 0,212)\end{array}$} & \multicolumn{2}{|c|}{$\begin{array}{c}0,093 \\
(0,017 \text { a } 0,169)\end{array}$} & \multicolumn{2}{|c|}{$\begin{array}{c}0,119 \\
(0,050 \text { a } 0,180)\end{array}$} \\
\hline$\hat{F}$ & \multicolumn{2}{|c|}{$\begin{array}{c}0,262 \\
(0,144 \times 0,361)\end{array}$} & \multicolumn{2}{|c|}{$\begin{array}{c}0,276 \\
(0,203 \times 0,340)\end{array}$} & \multicolumn{2}{|c|}{$\begin{array}{c}0,234 \\
(0,119 \times 0,343)\end{array}$} & \multicolumn{2}{|c|}{$\begin{array}{c}0,249 \\
(0,146 \text { a } 0,339)\end{array}$} \\
\hline
\end{tabular}

Campinas $=17$ progènies; lbicatu $=16$ progênies; Vassununga $=22$ progênies; a: coeficiente de coancestralidade entre populações; b: coeficiente de coancestralidade entre progênies/populações; $\left(\hat{\theta}_{F}\right)$ : Intervalo de confiança à $95 \%$ de probabilidade, estimado a partir de 10.000 reamostragens bootstrap sobre locos. 
Os níveis de fixação de alelos para o total das progênies dentro das populações $(\hat{F})$ foi alto e similar para as três populaçóes, com média de 0,249 (Tabela 29). O intervalo de

confiança de $\hat{F}$ mostra que a endogamia foi significativamente diferente de zero, mas não diferente entre as populações, reforçando a hipótese de baixas diferenças entre as populações e que a endogamia parece ser comum nas progênies de C. legalis. Por sua vez, comparando os valores $\hat{F}$ das progênies com o índice de fixação estimado para os adultos das populações naturais $\left(\hat{f}_{p}=0\right)$, observa-se indícios de seleção a favor de heterozigotos. Harritt (1991) avaliando árvores adultas de duas populações naturais de $C$. legalis observou excesso de heterozigotos dentro das populações $\left(\hat{f}_{p}=-0,113\right)$, corroborando com a hipótese de seleção para heterozigotos entre a fase de plântula para a fase adulta. Provavelmente, as populações de $C$. legalis liberam sementes com diferentes graus de endogamia, a cada evento reprodutivo, sendo que a seleção natural atua a favor dos heterozigotos, eliminando, em parte, os indivíduos homozigotos. A seleção para heterozigotos já foi muito discutida na literatura, sendo que existem fortes evidências para o fenômeno em essências florestais (Sampson et al., 1989; Murawsky, 1995; Reis, 1996; Kennington \& James, 1997; Sebbenn et al., 1998; Schimidt-Adam et al., 2000; Millar et al., 2000; entre outros). Levando em conta a natureza neutra das isoenzimas, pode-se atribuir a deteç̧ão de seleção para heterozigotos ao desequilíbrio de ligação entre locos isoenzimáticos a locos de efeitos adaptativos. Este aspecto também tem sido muito discutido na literatura, permanecendo, ainda hoje, muitas discordâncias e teorias entre diferentes grupos de pesquisadores. Contudo, as evidências parecem favorecer a hipótese de seleção.

A endogamia média ou fixação de alelos entre indivíduos dentro das progênies $(\hat{f})$ foi menor que a endogamia do conjunto das progênies e populações $(\hat{F})$, indicando que existem diferenças entre as progênies nos níveis de endogamia. Também se observa que a maior população (Vassununga) apresentou menores níveis de endogamia do que as duas outras populações, dando a entender que populações menores tendem a apresentar maior grau de endogamia. 
A proporção da variabilidade genética entre indivíduos dentro de progênies (Tabela 29) apresentou magnitude similar à variabilidade entre progênies, com valores entre 7,8 e $13,1 \%$. No entanto, a proporção da variabilidade entre genes dentro de indivíduos foi alta para todas as populações (média de $75,1 \%$ ), evidenciando que a maior parte da variabilidade genética se encontra dentro dos indivíduos, em concordância ao observado para a análise dos caracteres quantitativos.

\subsection{Variabilidade Genética Dentro das Populações}

\subsubsection{Caracteres Quantitativos}

As estimativas dos coeficientes de variação genética $\left(C \hat{V}_{8}\right)$, de modo geral, foram baixas para os caracteres nas populações (Tabela 30). Os maiores valores foram apresentados pela população Vassununga (máximo 17\% para VC). Siqueira et. al. (1986) analisando estes mesmos ensaios de C. legalis, aos 3 anos de idade, observaram valores de $C \hat{V}_{g}$ inferiores a $1,5 \%$ para DAP e altura. Sebbenn et al. $(2000 \mathrm{~b})$ avaliando este mesmo ensaio nas idades de 6,11 e 14 anos, observaram valores superiores aos encontrados por Siqueira et al. (1986), mas inferiores aos resultados atuais, o que indica que a variação genética está aumentando com a idade das plantas e que um número maior de genes está sendo expresso na fase atual (17 anos), relativamente às fases iniciais de crescimento.

$O$ coeficiente de varią̧ão fenotípico dentro de progênies $\left(C \hat{V}_{d}\right)$ apresentou estimativas similares entre populações para os caracteres FF, DAP e ALT, sendo sutilmente superior para a população Vassununga, mas de modo geral, indicando baixas diferenças entre populações. Para o VC, a estimativa de $C \hat{V}_{d}$ apresentou grandes diferenças entre populações.

Quanto à magnitude destes valores, Moraes (1993), encontrou na média 14 caracteres em duas populações de Myracrodruon urundeuva valores de 22,8 e 24,9\%, respectivamente. Dias \& Kageyama (1991) encontraram 22,3\% para a média de várias espécies arbóreas nativas brasileiras, nos caracteres DAP e ALT. Sebbenn et al. (2000b) analisando este ensaio aos 6, 11 e 14 anos de idade, observaram valores similares aos 
atuais para DAP e ALT. Considerando os razoáveis $C \hat{V}_{g}$ estimados e que em espécies de reprodução mista, aproximadamente $2 / 3$ da variância genética aditiva encontra-se dentro de progênies (Hamrick, 1976), pode-se esperar progressos genéticos com a seleção entre e dentro de progênies/populaçōes.

Tabela 30. Coeficiente de variação genética $\left(C \hat{V}_{g}\right)$ e coeficiente de variação fenotípico dentro de progênies $\left(C \hat{V}_{d}\right)$ para a análise conjunta dos locais, em populações de C. legalis.

\begin{tabular}{clcc}
\hline Caracteres & População & $C \hat{V}_{g}$ & $C \hat{V}_{d}$ \\
\hline \multirow{2}{*}{ FF } & Campinas & 0 & 14,3 \\
& Ibicatu & 2,4 & 14,9 \\
& Vassununga & 2,4 & 15,2 \\
& & & \\
\multirow{4}{*}{ DAP } & Campinas & 2,7 & 31,8 \\
& Ibicatu & 5,5 & 33,4 \\
& Vassununga & 6,7 & 35,6 \\
& Campinas & 3,1 & 22,8 \\
ALT & Ibicatu & 4,7 & 24,6 \\
& Vassununga & 3,5 & 23,8 \\
& & & 78,8 \\
& Campinas & 0 & 85,8 \\
& Ibicatu & 6,5 & 102,4 \\
\hline
\end{tabular}

Pop.1: Campinas $=17$ progênies; Pop. 2: Ibicatı $=16$ progênies; Pop.3: Vassununga 17 progênies, respectivamente.

\subsubsection{Dados de Isoenzimas}

Os índices de diversidade (Tabela 31) apresentaram valores altos e similares entre populações. Apesar da alta variabilidade genética observada, o índice $\hat{f}$ mostrou excesso significativo de homozigotos dentro das populações, sugerindo desvios do EHW. Os desvios podem ser atribuídos à ocorrência de autofecundações, cruzamentos entre aparentados e cruzamentos preferenciais nas populações, como já foi discutido na análise do sistema de reprodução (ítem 4.2. a e b) 
O tamanho efetivo $\left(\hat{N}_{e}\right)$ também foi similar entre as populações, sendo que a população Vassununga apresentou uma pequena superioridade, atribuída ao maior número de progênies amostradas e ao menor coeficiente de endogamia. A relação $\hat{N}_{e} / n$, foi baixa para as populações (média 0,16 ), revelando que a representatividade genética dos indivíduos é baixa. Por exemplo, cada 100 plantas amostradas na estrutura de progênies no ensaio representam apenas 16 plantas de uma população também estruturada em progênies, de tamanho infinito, praticando cruzamentos aleatórios (população de referência). Em populações-estruturadas em progênies, a correlação de parentesco existente entre os individuos de uma mesma progênie (meios irmãos; irmãos completos, $\mathrm{S} 1, \mathrm{~S} 2$ etc), reduz a estimativa do $\hat{N}_{e}$ pela redundância de alelos maternos e/ou paternos (idênticos por descendência).

Tabela 31. Número de alelos $(n A)$, tamanho médio da amostra $(n)$, índices de diversidade e relação $\hat{N}$. In para populações de $C$. legalis.

\begin{tabular}{|c|c|c|c|c|c|c|c|c|c|}
\hline População & $n A$ & $n$ & $\underset{(95 \%)}{\hat{P}}$ & $\hat{A}$ & $\hat{H}_{\circ}$ & $\hat{H}_{e}$ & $\hat{f}^{1}$ & $\hat{N}_{e}$ & $\hat{N}_{*} / n$ \\
\hline Campinas & 38 & 412 & 100 & $\begin{array}{c}2,7 \\
(0,2)\end{array}$ & $\begin{array}{c}0,263 \\
(0,028)\end{array}$ & $\begin{array}{c}0,348 \\
(0,037)\end{array}$ & $\begin{array}{c}0,249 \\
{[0,130 \text { a } 0,338]}\end{array}$ & 64,4 & 0,16 \\
\hline Ibicatu & 39 & 386 & 100 & $\begin{array}{l}2,8 \\
(0,2)\end{array}$ & $\begin{array}{c}0,267 \\
(0,026)\end{array}$ & $\begin{array}{c}0,350 \\
(0,032)\end{array}$ & $\begin{array}{c}0,242 \\
{[0,172 \mathrm{a} 0,296]}\end{array}$ & 66,7 & 0,17 \\
\hline Vassununga & 42 & 434 & 100 & $\begin{array}{c}3,0 \\
(0,2)\end{array}$ & $\begin{array}{c}0,287 \\
(0,032)\end{array}$ & $\begin{array}{c}0,366 \\
(0,035)\end{array}$ & $\begin{array}{c}0,220 \\
{[0,107 \mathrm{a} 0,320]}\end{array}$ & 68,8 & 0,16 \\
\hline Conjunta & 42 & 1.232 & 100 & $\begin{array}{c}3,0 \\
(0,2)\end{array}$ & $\begin{array}{c}0,273 \\
(0,028)\end{array}$ & $\begin{array}{c}0,358 \\
(0,035)\end{array}$ & $\begin{array}{c}0,239 \\
{[0,144 \text { a } 0,323]}\end{array}$ & 199,9 & 0,16 \\
\hline
\end{tabular}

(): Erro padrão da média; []: Intervalo de confiança à $95 \%$ de probabilidade, estimado a partir de 10.000 reamostragens "bootstraps".

A identidade por descendência aumenta à medida em que aumentam os cruzamentos entre aparentados, cruzamento preferenciais (irmãos completos), autofecundação, endogamia na geração parental e diferenças na fertilidade masculina e feminina dos progenitores, reduzindo a relação $\hat{N}_{e} / n$. Tomando-se como referência 
progênies de uma população ideal (população panmítica, infinitamente grandes, sem parentesco e endogamia na geração parental e com igual fertilidade masculina e feminina dos progenitores), a relação $\hat{N}_{e} / n$ seria de $1 / 4$ ou 0,25 , ou ainda, seu valor máximo populacional poderia ser estimado por $4 n F$, onde $n F$ é o número de progênies amostradas. Desta forma, as estimativas $\hat{N}_{e}$ poderiam atingir os valores máximos de 68,64 e 88 para a população Campinas, Ibicatu e Vassununga, respectivamente. Quaisquer desvios dos pressupostos apresentados para a população de referência levam às reduções na relação $\hat{N}_{e} / n$. Assim, a menor representatividade genética observada nas populações de C. legalis decorre do cruzamento entre aparentados, preferenciais e das autofecundações, tendo o $\hat{N}_{e}$ estimado atingido aproximadamente $64 \%$ do valor máximo possivel em progênies de polinização aberta de uma população ideal. Este resultado implica que a variabilidade genética conservada no ensaio será menor do que a esperada. Para contornar este problema, comum em progênies de polinização aberta, como não existe controle de parentesco dentro de progênies, a melhor estratégia é aumentar o número de matrizes amostradas nas populações naturais, tomando-se o cuidado de coletar as sementes de frutos diferentes de uma mesma planta materna. Assim, é possível reduzir o grau de parentesco nestas, para próximo de meios irmãos, aumentando o tamanho efetivo do banco de conservação ex situ.

Os maiores níveis de heterozigosidades $\left(\hat{H}_{o}\right.$ e $\left.\hat{H}_{e}\right)$, número médio de alelos por locos e tamanho efetivo e os menores de endogamia foram observados na população Vassununga, seguida pela Ibicatu e Campinas, em concordância aos obtidos para os coeficientes de variação genética e de variação fenotípica dentro de progênies, sugerindo que a maior população tende a manter maior variabilidade genética do que as populações menores. Entretanto, a similaridade nos índices de diversidade reforça a hipótese de que as populações foram originadas de um mesmo conjunto gênico, possivelmente de uma mesma população ancestral. Já, o excesso de homozigotos pode refletir os efeitos do processo de fragmentação como, deriva genética, aumento de autofecundação, cruzamentos preferenciais e até a escassez dos polinizadores. A fragmentação pode levar à deriva genética pelo estrangulamento da base genética, gerando excessos de homozigotos 
dentro das populações, efeito conhecido como Wanlund. Porém, os dados mostram que a deriva contribuiu pouco para o excesso de homozigotos, caso contrário, a diferenciação entre populações (Tabela 29), a qual mede o excesso de homozigotos devido à deriva genética, seria superior à observada para as progênies $(0,9 \%)$. Possivelmente, a melhor explicação para o excesso de homozigotos seja o sistema reprodutivo, como já discutido.

\subsection{CARACTERES QUANTITATIVOS VERSOS ISOENZIMAS}

Os resultados obtidos para a divergência genética entre populações por caracteres quantitativos e por isoenzimas foram consistentes, indicando que a maior parte da variabilidade genética encontra-se dentro das populações e somente uma pequena proporção entre populações. A magnitude dos resultados obtidos pelos dois métodos também foi similar, em algumas situações. Por exemplo, a estimativa de $\hat{\theta}_{p}$ foi de $0,9 \%$ e a estimativa de $\hat{\theta}_{p}$ obtido para caracteres quantitativos variou entre 0,1 a $6,0 \%$ para o FF (LA e conjunta), DAP, ALT e SOB. Moraes (1993) comparou a estrutura genética de duas populações de Myracrodruon urundeuva a partir de 14 caracteres quantitativos e de três sistemas isoenzimáticos, não encontrando diferenças entre populações para a média dos caracteres quantitativos, somente para as isoenzimas. O autor observou que $4,9 \%$ da variabilidade genética isoenzimática encontrava-se entre populações. Os resultados aqui observados, juntamente com os de Moraes (1993), reforçam a coerência das informações fornecidas por ambas as metodologias. Entretanto, a variabilidade genética observada entre progênies dentro de populações $\left(\hat{\sigma}_{F / P}^{2}\right)$, para isoenzimas, foi no mínimo o dobro da variabilidade encontrada para os dados de caracteres quantitativos, mostrando pouca congruência. Como já discutido anteriormente, os baixos valores da estimativa de $\hat{\sigma}_{F / P}^{2}$, para os caracteres quantitativos, possivelmente ocorreram porque às progênies eram de polinização aberta, constituídas de indivíduos com vários graus de parentesco entre si, inflando assim, a variação fenotípica dentro das progênies $\left(\hat{\sigma}_{d}^{2}\right)$, o que, por sua vez, pode ter mascarado a real variância entre progênies dentro de populações pela presença de correlações intraclasses. Como neste caso o parâmetro é medido sobre caracteres fenotípicos, controlados simultaneamente por componentes genéticos e ambientais, torna- 
se dificil determinar grandezas que caracterizem classes de parentesco. Por exemplo, progênies exclusivamente de meios irmãos podem apresentar magnitudes similares para a estimativa de $\hat{\sigma}_{F / P}^{2}$ às progênies resultantes de uma geração de autofecundação (S1). Já a magnitude da estimativa de $\hat{\sigma}_{F / p}^{2}$, estimada com dados de isoenzimas ou outros marcadores codominantes, devido à sua herança mendeliana, na maioria das situações, é exclusivamente dependente do tipo de parentesco existente entre as plantas dentro das progênies, o que por sua vez depende da forma de reprodução, assumindo valores de 0,125 em progênies de meios irmãos, 0,25 em progênies de irmãos completos, 0,5 em progênies $S 1,0,75$ em progênies $S 2$ etc. Contudo, a variância $\hat{\sigma}_{F / p}^{2}$ pode apresentar valores intermediários quando ocorrer misturas de diferentes graus de parentescos dentro das progênies. Por exemplo, misturas de progênies de meios irmãos e de autofecundação podem apresentar valores de $\hat{\sigma}_{F / p}^{2}$, variando entre 0,125 a 0,5 , sendo a tendência para um ou outro sentido, dada pela proporção de diferentes tipos de progênies. Assim, as medidas de $\hat{\sigma}_{F / P}^{2}$ obtidas, por isoenzimas podem ser previstas ou utilizadas para aferir o grau de parentesco entre progênies, o que jả não é possível com a estimativa da $\hat{\sigma}_{F / P}^{2}$ obtida por caracteres quantitativos. A estimativa da $\hat{\sigma}_{d}^{2}$, obtida para caracteres quantitativos (Tabela 27), é comparável à variabilidade entre genes dentro de indivíduos somada à variabilidade genética entre indivíduos dentro de progênies $\left(\hat{\sigma}_{\sigma / I}^{2}+\hat{\sigma}_{I / F}^{2}\right)$, obtida de dados de isoenzimas (Tabela 29). Observa-se assim, forte coerência entre os dois métodos, mostrando que no mínimo $85 \%$ da variabilidade genética encontra-se entre índivíduos dentro das progênies.

Os resultados da estrutura genética de populações, encontrados para caracteres quantitativos e dados de isoenzimas mostram, de modo geral, consistência e complementariedade entre si; portanto, a escolha do método a ser utilizado torna-se uma função dos objetivos do trabalho. Por exemplo, a caracterização da estrutura de populações para a conservação in situ pode ser rápida, eficiente e facilmente realizada pela eletroforese de isoenzimas ou microssatélites e a caracterização de populações para a conservação ex situ ou para melhoramento, pode ser mais eficientemente realizada em 
ensaios de campo, dado que permitem a avaliação também da adaptação ao ambiente de ensaio. Contudo, mesmo neste último caso, a avaliação do sistema de reprodução, do parentesco e da endogamia da geração parental, a partir de um marcador codominante, são de fundamental importância, permitindo a adoção de modelos genéticos estatísticos acurados, levando à maior precisão na estimativa de parâmetros genéticos e adoção de estratégias refinadas de conservação e melhoramento genético. 


\subsection{DEPRESSÃo POR ENDOGAMIA}

A análise de isoenzimas permitiu a comparação da diversidade gênica dentro das progênies/população com seu desempenho fenotípico (Tabela 32 a 34). $O$ índice de fixação para a média das progênies foi inferior ao obtido para o conjunto das progênies, 0,239 (Tabela 31), mas apresentou o mesmo padrão, ou seja, a população de menor endogamia continuou sendo a Vassununga.

As progênies da população Campinas e Ibicatu (Tabela 32 e 34) apresentaram índices de fixação positivos, variando de 0,034 a 0,269 , revelando excessos de homozigotos. Na população Vassununga os valores de $\hat{f}$ variaram de negativos $(-0,124)$ a positivos $(0,191)$, mostrando que algumas progênies apresentam excesso de heterozigotos e outras de homozigotos, respectivamente. Os índices negativos sugerem a presença de seleção para heterozigotos ou, em outras palavras, heterose ou sobredominância, provavelmente devido a ligação entre locos isoezimáticos a locos de efeito adaptativos. Por exemplo: na população Campinas (Tabela 32) a progênie 11 apresentou o melhor desempenho para os caracteres DAP, ALT e VC $(15,29 \mathrm{~cm}, 11,63$ $\mathrm{m}$ e $0,260 \mathrm{~m}^{3} / \mathrm{ha}$, respectivamente) e o maior número médio de alelos por locos $(2,57)$, heterozigosidade observada $(0,332)$, uma das maiores heterozigosidades esperadas $(0,359)$, bem como um dos menores índices de fixação $(0,078)$, além de ter sido gerada totalmente por cruzamentos $\left(\hat{t}_{m}=1,0\right)$. Já a progênie 15 apresentou o menor DAP e VC $\left(11,88 \mathrm{~cm} \mathrm{e} 0,143 \mathrm{~m}^{3} / \mathrm{ha}\right)$, a progênie 16 a menor ALT $(9,79 \mathrm{~m})$, sendo que ambas apresentaram heterozigosidades observadas menores que a média das progênies, um dos maiores índices de fixação $(0,248$ e 0,269$)$ e taxas de cruzamento inferiores a 1,0 , corroborando com a hipótese de heterose.

Na população Vassununga (Tabela 34), a progênie 44 apresentou o melhor crescimento para ALT $(10,15 \mathrm{~m})$ e a progênies 35 para VC $\left(0,225 \mathrm{~m}^{3} / \mathrm{ha}\right)$ sendo que suas heterozigosidades observadas foram superiores a média entre progênies $(0,265)$ e $o$ índice de fixação da progênie 44 foi negativo $(-0,063)$ e da 35 foi praticamente zero $(0,001)$, também sugerindo heterose. Por sua vez, a progênie 34 apresentou o menor DAP, ALT e

$\mathrm{VC}$, e heterozigosidade observada $(0,238)$ e esperada $(0,271)$ abaixo da média e $\hat{f}$ alto $(0,127)$, bem como uma das menores taxas de cruzamento na população $(0,67)$. 
Tabela 32. Tamanho amostral para isoenzimas (n), número médio de alelos por locos $(\hat{A})$, porcentagem de locos polimórficos $(\hat{P})$, média dos caracteres para os dois locais de ensaio (FF, DAP, ALT e VC), heterozigosidade observada $\left(\hat{H}_{o}\right)$, esperada $\left(\hat{H}_{e}\right)$, índice de fixação $(\hat{f})$ e taxa de cruzamento $\left(\hat{t}_{m}\right)$ para progênies e média entre progênies da populações Campinas de C. legalis.

\begin{tabular}{|c|c|c|c|c|c|c|c|c|c|c|c|}
\hline Prog. & $n$ & $\hat{A}$ & $\underset{(95 \%)}{\hat{P}}$ & FF & DAP & ALT & $\mathrm{VC}$ & $\hat{H}_{o}$ & $\hat{H}_{e}$ & $\hat{f}^{1}$ & $\hat{t}_{m}$ \\
\hline 1 & 23 & 2,36 & 92,9 & 1,89 & 12,72 & 10,96 & 0,212 & 0,268 & 0,284 & 0,057 & 1,00 \\
\hline 2 & 19 & 2,36 & 92,9 & 1,89 & 14,03 & & 0,220 & 4 & ,301 & 25 & 1,00 \\
\hline 3 & 28 & 2,29 & 92,9 & 1,98 & 12,91 & 11,16 & 0,191 & 0,286 & 296 & 0,034 & 1,00 \\
\hline 4 & 25 & 2,29 & 78,6 & 1,94 & 14,10 & 11,55 & 0,210 & 0,264 & 0,298 & 0,114 & 0,97 \\
\hline 5 & 24 & 2,29 & 100 & 1,88 & 13,99 & 11,15 & 0,218 & 0,297 & 0,384 & 0,231 & 0,92 \\
\hline 6 & 17 & 2,29 & 100 & 1,88 & 13,32 & 11,30 & 0,188 & 0,298 & 0,322 & 0,076 & 1,00 \\
\hline 7 & 27 & 2,29 & 100 & 1,87 & 12 & & 0,182 & 0,2 & & 0,018 & 1,00 \\
\hline 8 & 30 & 2,50 & 78,6 & 1,88 & 15,05 & & 0,236 & 0,254 & 0,307 & 0,175 & 1,00 \\
\hline 9 & 28 & 2,35 & 100 & 1,90 & 13,67 & 11,07 & 0,214 & 0,271 & 0,301 & 0,103 & 0,99 \\
\hline 10 & 20 & 2,21 & 100 & 1,79 & 14,00 & 11,12 & 0,199 & 0,261 & 0,312 & 0,167 & 0,98 \\
\hline 11 & 24 & 2,57 & 71,4 & 1,91 & 15,29 & 11,63 & 0,260 & 0,332 & 0,359 & 0,078 & 1,00 \\
\hline 12 & 21 & 2,14 & 92,6 & 1,81 & 13,98 & 10,61 & 0,203 & 0,236 & 0,270 & 0,130 & 1,00 \\
\hline 13 & 17 & 2,43 & 78,6 & 1,82 & 13,84 & 10,5 & 0,203 & 0,27 & 366 & 0,252 & 1,00 \\
\hline 14 & 31 & 2, & 92,6 & 1,90 & 14,52 & 11, & 0,235 & & & 0,157 & 1,00 \\
\hline 15 & 28 & 2,21 & 85,7 & 1,87 & 11 , & & 0,143 & & & 0,248 & 0,99 \\
\hline 16 & 27 & 2,43 & 92,6 & 1,83 & 12,39 & 9,79 & 0,157 & 0,229 & 0,312 & 0,269 & 0,96 \\
\hline 17 & 21 & 2,36 & 85,7 & 1,96 & 14,16 & 11,49 & 0,240 & 0,222 & 0,249 & 0,110 & 1,00 \\
\hline Média & $\begin{array}{l}23,6 \\
(4,3)\end{array}$ & $\begin{array}{c}2,3 \\
(0,1)\end{array}$ & $\begin{array}{l}89,5 \\
(9,8)\end{array}$ & $\begin{array}{c}1,88 \\
(0,011)\end{array}$ & $\begin{array}{c}13,68 \\
(0,217)\end{array}$ & $\begin{array}{r}11,12 \\
(0,137)\end{array}$ & $\begin{array}{c}0,207 \\
(0,006)\end{array}$ & $\begin{array}{c}0,265 \\
(0,029)\end{array}$ & $\begin{array}{c}0,307 \\
(0,036)\end{array}$ & $\begin{array}{c}0,142 \\
{[, 0,047 \mathrm{a}} \\
0,228]^{1}\end{array}$ & $\begin{array}{c}0,990 \\
(0,009)\end{array}$ \\
\hline
\end{tabular}

$\mathrm{FF}=$ forma do fuste; $\mathrm{DAP}=$ diâmetro a altura do peito $(1,3 \mathrm{~m}) ; \mathrm{ALT}=$ altura; $\mathrm{VC}=$ volume cilíndrico; (): Desvio padrão da média;

[ ] $]^{1}$ Intervalo de confiança a $95 \%$ de probabilidade, estimado a partir de 10.000 bootstraps. 
Tabela 33. Tamanho amostral para isoezimas $(n)$, número médio de alelos por locos $(\hat{A})$, porcentagem de locos polimórficos $(\hat{P})$, média dos caracteres para os dois locais de ensaio (FF, DAP, ALT e VC), heterozigosidade média observada $\left(\hat{H}_{o}\right)$, esperada $\left(\hat{H}_{e}\right)$, índice de fixação $(\hat{f})$ e taxa de cruzamento $\left(\hat{t}_{m}\right)$ para progênies e média entre progênies da populações Ibicatu de C. legalis.

\begin{tabular}{cccccccccccc}
\hline Prog & $n$ & $\hat{A}$ & $\begin{array}{c}\hat{P} \\
(99 \%)\end{array}$ & FF & DAP & ALT & VC & $\hat{H}_{o}$ & $\hat{H}_{e}$ & $\hat{f}^{1}$ & $\hat{t}_{m}$ \\
\hline 18 & 30 & 2,48 & 92,9 & 1,74 & 12,63 & 9,69 & 0,174 & 0,290 & 0,325 & 0,108 & 1,00 \\
19 & 26 & 2,36 & 85,7 & 1,81 & 12,61 & 10,57 & 0,165 & 0,303 & 0,342 & 0,116 & 0,94 \\
20 & 23 & 2,36 & 92,9 & 1,93 & 14,14 & 11,74 & 0,228 & 0,237 & 0,316 & 0,245 & 0,96 \\
21 & 27 & 2,29 & 85,7 & 1,93 & 13,68 & 11,26 & 0,194 & 0,218 & 0,265 & 0,180 & 1,00 \\
22 & 20 & 2,14 & 78,6 & 1,77 & 11,72 & 10,37 & 0,148 & 0,226 & 0,241 & 0,066 & 1,00 \\
23 & 31 & 2,29 & 100 & 1,81 & 13,08 & 10,46 & 0,182 & 0,307 & 0,346 & 0,113 & 1,00 \\
24 & 22 & 2,21 & 85,7 & 1,90 & 13,99 & 11,35 & 0,209 & 0,244 & 0,318 & 0,238 & 0,89 \\
25 & 23 & 2,14 & 92,9 & 1,87 & 12,32 & 10,64 & 0,171 & 0,257 & 0,329 & 0,220 & 0,92 \\
26 & 27 & 2,36 & 85,7 & 1,81 & 11,92 & 10,53 & 0,142 & 0,276 & 0,286 & 0,036 & 1,00 \\
27 & 24 & 2,43 & 100 & 1,82 & 12,77 & 10,87 & 0,190 & 0,263 & 0,324 & 0,191 & 0,98 \\
28 & 22 & 2,21 & 78,6 & 1,77 & 12,90 & 9,70 & 0,221 & 0,279 & 0,300 & 0,072 & 0,87 \\
29 & 21 & 2,21 & 64,3 & 1,74 & 12,20 & 10,16 & 0,145 & 0,217 & 0,274 & 0,213 & 0,94 \\
30 & 22 & 2,29 & 92,9 & 1,89 & 13,01 & 11,38 & 0,187 & 0,294 & 0,329 & 0,108 & 1,00 \\
31 & 25 & 2,36 & 92,9 & 1,88 & 13,18 & 10,83 & 0,195 & 0,276 & 0,345 & 0,202 & 1,00 \\
32 & 28 & 2,29 & 100 & 1,75 & 12,47 & 10,63 & 0,157 & 0,295 & 0,326 & 0,100 & 0,91 \\
33 & 15 & 2,14 & 85,7 & 1,74 & 12,33 & 9,69 & 0,164 & 0,245 & 0,277 & 0,120 & 0,96 \\
\hline Méd. & 23,6 & 2,3 & 88,4 & 1,72 & 12,17 & 9,96 & 0,171 & 0,264 & 0,309 & 0,147 & 0,976 \\
& $(3,9)$ & $(0,1)$ & $(9,4)$ & $(0,108)$ & $(0,779)$ & $(0,651)$ & $(0,013)$ & $(0,030)$ & $(0,031)$ & {$[0,100 \mathrm{a}$} & $(0,011)$ \\
\hline
\end{tabular}

$\mathrm{FF}=$ forma do fuste; $\mathrm{DAP}=$ diâmetro a altura do peito $(1,3 \mathrm{~m}) ; \mathrm{ALT}=$ altura; $\mathrm{VC}=$ volume cilíndrico; (): Desvio padrão da média;

[] $]^{\mathrm{i}}$ : Intervalo de confiança a $95 \%$ de probabilidade, estimado a partir de 10.000 bootstraps. 
Tabela 34. Tamanho amostral para isoezimas $(n)$, número médio de alelos por locos $(\hat{A})$, porcentagem de locos polimórficos $(\hat{P})$, média dos caracteres para os dois locais de ensaio (FF, DAP, ALT e VC), heterozigosidade observada $\left(\hat{H}_{o}\right)$, esperada $\left(\hat{H}_{e}\right)$, índice de fixação $(\hat{f})$ e taxa de cruzamento $\left(\hat{t}_{m}\right)$ para progênies e média entre progênies da populações Vassununga de $C$. legalis.

\begin{tabular}{cccccccccccc}
\hline Prog & $n$ & $\hat{A}$ & $\begin{array}{c}\hat{P} \\
(95 \%)\end{array}$ & FF & DAP & ALT & VC & $\hat{H}_{o}$ & $\hat{H}_{e}$ & $\hat{f}^{1}$ & $\hat{t}_{m}$ \\
\hline 34 & 9 & 1,93 & 85,7 & 1,61 & 9,72 & 6,26 & 0,104 & 0,238 & 0,271 & 0,127 & 0,67 \\
35 & 22 & 2,45 & 92,9 & 1,62 & 10,62 & 8,52 & 0,225 & 0,312 & 0,312 & 0,001 & 0,93 \\
36 & 22 & 2,29 & 92,9 & 1,60 & 13,43 & 9,64 & 0,188 & 0,322 & 0,387 & 0,171 & 0,64 \\
37 & 21 & 2,43 & 85,7 & 1,66 & 13,11 & 9,13 & 0,174 & 0,301 & 0,298 & $-0,011$ & 0,95 \\
38 & 16 & 2,36 & 92,9 & 1,62 & 10,83 & 8,83 & 0,159 & 0,255 & 0,305 & 0,168 & 0,90 \\
39 & 20 & 2,43 & 92,9 & 1,71 & 10,87 & 8,06 & 0,130 & 0,329 & 0,334 & 0,016 & 0,8 \\
40 & 13 & 2,14 & 78,6 & 1,54 & 10,94 & 8,60 & 0,110 & 0,314 & 0,281 & $-0,124$ & 0,94 \\
41 & 23 & 2,29 & 92,9 & 1,60 & 10,59 & 8,05 & 0,170 & 0,292 & 0,332 & 0,122 & 0,84 \\
42 & 21 & 2,43 & 85,7 & 1,50 & 9,74 & 7,87 & 0,128 & 0,291 & 0,315 & 0,080 & 1,00 \\
43 & 14 & 2,14 & 78,6 & 1,77 & 9,75 & 8,57 & 0,129 & 0,230 & 0,278 & 0,175 & 1,00 \\
44 & 13 & 2,14 & 78,6 & 1,76 & 12,90 & 10,15 & 0,150 & 0,297 & 0,280 & $-0,063$ & 0,93 \\
45 & 17 & 2,14 & 92,9 & 1,73 & 12,00 & 9,21 & 0,181 & 0,309 & 0,303 & $-0,020$ & 1,00 \\
46 & 25 & 2,29 & 85,7 & 1,61 & 10,50 & 8,78 & 0,164 & 0,330 & 0,331 & 0,005 & 0,90 \\
47 & 16 & 2,21 & 85,7 & 1,69 & 13,57 & 9,66 & 0,241 & 0,302 & 0,308 & 0,021 & 1,00 \\
48 & 20 & 2,07 & 78,6 & 1,64 & 11,79 & 9,29 & 0,122 & 0,196 & 0,244 & 0,199 & 0,91 \\
49 & 22 & 2,36 & 85,7 & 1,69 & 12,30 & 8,31 & 0,201 & 0,291 & 0,319 & 0,089 & 1,00 \\
50 & 20 & 2,50 & 100 & 1,68 & 11,84 & 8,83 & 0,207 & 0,312 & 0,385 & 0,192 & 0,81 \\
51 & 25 & 2,35 & 92,9 & 1,60 & 11,15 & 9,07 & 0,149 & 0,294 & 0,315 & 0,070 & 1,00 \\
52 & 22 & 2,14 & 64,3 & 1,60 & 11,86 & 8,57 & 0,204 & 0,258 & 0,272 & 0,054 & 0,86 \\
53 & 26 & 2,14 & 78,6 & 1,72 & 12,26 & 9,11 & 0,155 & 0,236 & 0,291 & 0,191 & 0,96 \\
54 & 25 & 2,36 & 92,9 & 1,85 & 10,46 & 7,86 & 0,178 & 0,315 & 0,350 & 0,102 & 0,99 \\
55 & 24 & 2,29 & 85,7 & 1,62 & 10,58 & 6,59 & 0,140 & 0,257 & 0,305 & 0,159 & 1,00 \\
\hline Méd. & 19,6 & 2,3 & 86,4 & 1,77 & 12,24 & 10,33 & 0,164 & 0,265 & 0,310 & 0,081 & 0,901 \\
& $(4,7)$ & $(0,1)$ & $(9,5)$ & $(0,095)$ & $(0,620)$ & $(0,510)$ & $(0,012)$ & $(0,029)$ & $(0,035)$ & {$[0,013 \mathrm{a}$} & $(0,025)$ \\
\hline
\end{tabular}

$\mathrm{FF}=$ forma do fuste $; \mathrm{DAP}=$ diâmetro a altura do peito $(1,3 \mathrm{~m}) ; \mathrm{ALT}=$ altura; $\mathrm{VC}=$ volume cilindrico; (): Desvio padrão da média;

[ ] $]^{1}$ : Intervalo de confiança a $95 \%$ de probabilidade, estimado a partir de 10.000 bootstraps. 
Os resultados observados para as progênies 44,35 e 34 indicam a presença de forte seleção para heterozigotos. Contudo, nesta mesma população a progênie 36 apesar de apresentar o melhor crescimento para o $\operatorname{DAP}(13,43 \mathrm{~cm})$, teve valor de $\hat{f}$ positivo e alto $(0,171)$ e apresentou menor taxa de cruzamento $(0,64)$, sugerindo ausência de seleção para heterozigotos. Da mesma forma, na população Ibicatu (Tabela 33), a progênie 20 apresentou a melhor performance para o DAP, ALT e VC $(14,14 \mathrm{~cm}, 11,74 \mathrm{~m}$ e 0,228 $\mathrm{m}^{3} / \mathrm{ha}$, respectivamente), mas sua heterozigosidade observada foi menor que a média $(0,237)$ e o $\hat{f}$ foi o maior $(0,245)$ da população. Igualmente, a progênie 22 apresentou o menor DAP $(11,72 \mathrm{~cm})$ e heterozigosidades observada e esperada abaixo da média, porém, um $\hat{f}$ próximo a zero $(0,066)$. Por sua vez, a progênie 18 apresentou uma das menores alturas $(9,69 \mathrm{~m})$, heterozigosidades superiores a média, mas indice $\hat{f}$ alto $(0,108)$. A progênie 33 apresentou a mesma altura $(9,69 \mathrm{~m})$ que a progênie 18 , porém. ambas heterozigosidades foram inferiores a média da população, porém com índice $\hat{f}$ alto $(0,120)$. Já a progênie 26 apresentou o menor VC $\left(0,142 \mathrm{~m}^{3} / \mathrm{ha}\right)$, e o menor $\hat{f} \mathrm{da}$ população. Assim, os resultados sugerem que na população Ibicatu, parece não estar ocorrendo seleção para heterozigotos.

Ainda, comparando-se o indice de fixação e a taxa de cruzamento individual por progênie nas três populações, não parece evidente que as menores taxa de cruzamento estejạm obrigatoriamente associadas aos maiores índices de fixação.

As associações entre os caracteres quantitativos e os índices de diversidade de maior importância $\left(\hat{H}_{o}, \hat{H}_{\varepsilon}, \hat{f}\right.$ e $\left.\hat{t}_{m}\right)$ podem ser melhor entendida por uma análise de regressão linear (Tabela 35). Foram incluídas, também, regressões da variância fenotípica dentro de progênies para os caracteres DAP e ALT, sobre os índices de diversidade, a fim de verificar a existência do aumento da variação fenotípica dentro das progênies com o aumento da endogamia. 
Tabela 35. Coeficiente de regressão $(\hat{b})$ e coeficiente de determinação $\left(\hat{r}^{2}\right)$ da forma do fuste (FF), DAP, altura (ALT), volume cilíndrico (VC), variância fenotípica dentro de progênies para $\operatorname{DAP}\left(\hat{\sigma}_{d(D A P)}^{2}\right)$ e $\operatorname{ALT}\left(\hat{\sigma}_{d(A L \tau)}^{2}\right)$ sobre $\hat{H}_{o}, \hat{f}$ e $\hat{t}_{m}$ em três populações de C. legalis.

\begin{tabular}{|c|c|c|c|c|c|c|c|}
\hline \multirow[b]{2}{*}{ Pop. } & \multirow[b]{2}{*}{ Caráter } & \multicolumn{2}{|l|}{$\hat{H}_{\circ}$} & \multicolumn{2}{|l|}{$\hat{f}$} & \multicolumn{2}{|l|}{$\hat{t}_{m}$} \\
\hline & & $\hat{b}$ & $\hat{r}^{2}$ & $\hat{b}$ & $\hat{r}^{2}$ & $\hat{b}$ & $\hat{r}^{2}$ \\
\hline \multirow{6}{*}{ Campinas } & $\mathrm{FF}$ & $0,26(0,44)$ & 0,02 & $-0,35(0,15)^{*}$ & 0,28 & $0,32(0,52)$ & 0,02 \\
\hline & DAP & $-17,15(10,97)$ & 0,14 & $7,66(4,10)$ & 0,19 & $10,29(15,94)$ & 0,03 \\
\hline & ALT & $5,72(4,86)$ & 0,08 & $-3,92(1,67)^{*}$ & 0,27 & $6,83(6,72)$ & 0,06 \\
\hline & VC & $0,24(0,25)$ & 0,06 & $-0,11(0,09)$ & 0,09 & $0,23(0,34)$ & 0,03 \\
\hline & $\hat{\sigma}_{d(D A P)}^{2}$ & $-49,85(35,80)$ & 0,11 & $-0,18(14,64)$ & 0,00 & $-7,68(51,91)$ & 0,00 \\
\hline & $\hat{\sigma}_{d(A L T)}^{2}$ & $13,72(20,28)$ & 0,03 & $-2,85(7,89)$ & 0,09 & $-11,40(27,97)$ & 0,01 \\
\hline \multirow{6}{*}{ Ibicatu } & $\mathrm{FF}$ & $-0,43(0,60)$ & 0,04 & $0,59(0,23) *$ & 0,32 & $0,20(0,41)$ & 0,02 \\
\hline & DAP & $-1,98(6,09)$ & 0,01 & $6,26(2,23) *$ & 0,36 & $-1,92(4,14)$ & 0,01 \\
\hline & ALT & $-3,51(5,40)$ & 0,03 & $4,96(2,11)^{*}$ & 0,28 & $1,79(3,71)$ & 0,02 \\
\hline & $\mathrm{VC}$ & $0,02(0,26)$ & 0,00 & $-0,03(0,11)$ & 0,00 & $-0,00(0,17)$ & 0,00 \\
\hline & $\hat{\sigma}_{d(D A P)}^{2}$ & $63,32(71,10)$ & 0,05 & $-23,19(32,67)$ & 0,04 & $-69,42(46,28)$ & 0,13 \\
\hline & $\hat{\sigma}_{d(A L T)}^{2}$ & $-5,44(24,56)$ & 0,03 & $1,55(11,19)$ & 0,00 & $-16,19(16,22)$ & 0,07 \\
\hline \multirow{6}{*}{ Vassununga } & $\mathrm{FF}$ & $0,01(0,49)$ & 0,00 & $0,07(0,20)$ & 0,01 & $0,19(0,17)$ & 0,06 \\
\hline & DAP & $5,91(7,11)$ & 0,03 & $-1,89(2,86)$ & 0,02 & $-0,50(2,54)$ & 0,02 \\
\hline & AlT & $4,17(5,30)$ & 0,03 & $-2,21(2,09)$ & 0,05 & $0,82(1,88)$ & 0,01 \\
\hline & VC & $0,41(0,21)$ & 0,16 & $-0,02(0,09)$ & 0,00 & $0,03(0,08)$ & 0,01 \\
\hline & $\hat{\sigma}_{d(D A P)}^{2}$ & $49,32(31,80)$ & 0,11 & $-3,25(13,42)$ & 0,03 & $8,41(11,60)$ & 0,02 \\
\hline & $\hat{\sigma}_{d(A L T)}^{2}$ & $24,73(22,35)$ & 0,06 & $15,64(8,50)$ & 0,14 & $-6,18(7,96)$ & 0,03 \\
\hline
\end{tabular}

$*: P \leq 0,05$

As regressões dos caracteres quantitativos sobre os índices de diversidade não foram significativas para a maioria da situações, com exceção do FF e ALT sobre o $\hat{f}$ na população Campinas e FF, DAP e ALT sobre o $\hat{f}$ na população Ibicatu. No caso da população Campinas, quanto maior o índice de fixação $(\hat{f})$, pior é a FF e menor é ALT, o que condiz com a hipótese de depressão por endogamia ou que quanto maior a endogamia dentro das progênies, pior é a FF e menor é a ALT. No entanto, no segundo caso, da população Ibicatu, o resultado foi justamente o oposto, ou seja, quanto maior a endogamia melhor é o FF e maior é o DAP e a ALT, mostranto inconsistência na relação 
de dependência. No entanto, os coeficientes de determinação $\left(\hat{r}^{2}\right)$ foram baixos em todas as situações, inclusive nos casos em que o coeficiente de regressão $(b)$ foi significativo. Os resultados sugerem independência entre as variáveis quantitativas e os índices de diversidade e que o marcador é neutro, logo os locos analisados não estão influenciando os caracteres avaliados.

As variâncias fenotípicas dentro de progênies para o DAP $\left(\hat{\sigma}_{d(D A P)}^{2}\right)$ e para altura $\left(\hat{\sigma}_{d(A L T)}^{2}\right)$ revelaram para a maioria das situações que os valores do coeficiente de regressão $(b)$ sobre $\hat{f}$ foram negativos, indicando o aumento da variação fenotípica com a redução da endogamia, resultado este que não condiz com a hipótese de depressão por endogamia. Sorensem \& White (1988) observaram aumendo da variação fenotípica em progênies de autofecundação, relativamente a progênies de cruzamentos. So existe depressão por endogamia na presença de dominância (Crow \& Kimura, 1970) a qual é esperada aumentar a variação fenotípica dentro de progênies.

A falta de consistência nos resultados pode ter sido causada pela natureza neutra das isoenzimas, sendo as associações positivas obras do acaso ou ainda, estarem relacionadas ao fato dos índices de diversidade terem sido estimados por amostragem de aproximadamente $1 / 3$ dos indivíduos ensaidos e as médias dos caracteres para todos os indivíduos ensaiados. Assim, com o intuito de um melhor entendimento da relação entre o desempenho fenotípico e os índices de diversidade, foram reestimadas as médias fenotípicas dos caracteres quantitativos apenas para os indivíduos genotipados para isoenzimas. Estes tipo de abordagem permite inferir sobre a possível depressão por endogamia que pode estar ocorrendo nas progênies de polinização aberta de $C$. legalis.

A depressão por endogamia foi abordada, criando-se cinco classes de distribuição fenotípicas em cada população, com base no DAP e estimando-se seus respectivos parâmetros heterozigosidade observada e índices de fixação (Tabela 36).

Os resultados mostraram uma evidente tendência entre os caracteres e a heterozigosidade observada e o índice de fixação. Quanto maior o crescimento dos caracteres maior é a heterozigosidade e menor é o índice de fixação. Porém, verificandose o intervalo de confiança de $\hat{f}$, observa-se que seus valores entre as classes, nas 
populações, não foram significativamente diferentes, com exceção da classe 1 e 5 na população Vassununga, a qual mostrou diferenças significativas.

Tabela 36. Tamanho da amostra (n), média fenotípica para quatro caracteres (FF, DAP, ALT, VC), heterozigosidade observada $\left(\hat{H}_{o}\right)$ e índice de fixação $(\hat{f})$, para cinco intervalos de classes em três populações de $C$. legalis.

\begin{tabular}{|c|c|c|c|c|c|c|c|c|}
\hline Pop. & Classe & $n$ & FF & $\begin{array}{l}\text { DAP } \\
(\mathrm{cm})\end{array}$ & $\begin{array}{l}\text { ALT } \\
(\mathrm{m})\end{array}$ & $\begin{array}{l}\mathrm{VC} \\
\left(\mathrm{m}^{3}\right)\end{array}$ & $\hat{H}_{\circ}$ & $\hat{f}(\mathrm{IC})$ \\
\hline \multirow{5}{*}{ Camp. } & 1 & 46 & 1,52 & 6,24 & 5,30 & 0,020 & 0,212 & $0,459(0,372$ a 0,535$)$ \\
\hline & 2 & 83 & 1,76 & 10,28 & 8,62 & 0,082 & 0,259 & $0,368(0,246$ a 0,471$)$ \\
\hline & 3 & 126 & 1,92 & 13,78 & 11,29 & 0,189 & 0,253 & $0,359(0,248$ a 0,459$)$ \\
\hline & 4 & 115 & 1,93 & 15,97 & 12,36 & 0,267 & 0,267 & $334(0,197$ a 0,459$)$ \\
\hline & 5 & 52 & 2,07 & 19,64 & 14,59 & 0,483 & 0,265 & $331(0,19$ \\
\hline \multirow{5}{*}{ Ibicatu } & 1 & 42 & 1,47 & 4,91 & 4,89 & 0,012 & 0,219 & $0,422(0,31)$ \\
\hline & 2 & 84 & 1,74 & 8,56 & 8,52 & 0,053 & 0,256 & $0,334(0,237$ a 0,439$)$ \\
\hline & 3 & 149 & 1,85 & 12,95 & 10,88 & 0,150 & 0,264 & $0,327(0,205$ a 0,446$)$ \\
\hline & 4 & 80 & 1,92 & 17,71 & 13,10 & 0,332 & 0,279 & $0,317(0,209$ a 0,428$)$ \\
\hline & 5 & 31 & 1,85 & 22,18 & 14,17 & 0,583 & 0,275 & $0,305(0,164 \mathrm{a} 0,430)$ \\
\hline \multirow{5}{*}{ Vassun } & ] & 63 & 1,46 & 4,58 & 5,17 & 0,010 & 0,214 & \\
\hline & 2 & 107 & 1,70 & 8,59 & 8,66 & 0,054 & 0,235 & $0,382(0,282$ a 0,478$)$ \\
\hline & 3 & 139 & 1,85 & 12,83 & 11,48 & 0,154 & 0,299 & $0,267(0,126$ a 0,414$)$ \\
\hline & 4 & 80 & 1,91 & 17,75 & 13,42 & 0,364 & 0,329 & $0,221(0,076$ a 0,371$)$ \\
\hline & 5 & 39 & 1,88 & 23,09 & 15,01 & 0,665 & 0,378 & $0,198(0,069$ а 0,317$)$ \\
\hline
\end{tabular}

IC: Intervalo de confiança a $95 \%$ de probabilidade, estimado a partir de 10.000 reamostragens boodstrap sobre locos.

As associações estatísticas entre os caracteres e os parâmetros $\hat{H}_{0}$ e $\hat{f}$ para as classes de crescimento nas populações foi avaliada pelo coeficiente de regressão linear $(\hat{b})$ e determinação $\left(\hat{r}^{2}\right)$ (Tabela 37 e 38 ). 
Tabela 37. Intercepto $(\hat{a})$, coeficiente de regressão $(\hat{b})$ e coeficiente de determinação para regressão linear $\left[\hat{r}^{2}\right.$ (Eq. linear)] e exponencial de $\left[\hat{r}^{2}\right.$ (Eq. exp.)] para os caracteres sobre a heterozigosidade observada $\left(\hat{H}_{o}\right)$, em três populações de C. legalis.

\begin{tabular}{cccccc}
\hline Pop. & Caráter & $\hat{a}$ & $\hat{b}$ & $\hat{r}^{2}$ (Eq. linear) & $\hat{r}^{2}$ (Eq. exp.) \\
\hline \multirow{5}{*}{ Campinas } & FF & $-0,21(0,65)$ & $8,16(2,56)^{*}$ & $0,70^{*}$ & $0,77^{*}$ \\
& DAP & $-34,05(18,86)$ & $188,03(74,84)$ & 0,57 & $0,73 *$ \\
& ALT & $-23,59(12,02)$ & $47,68(2,84)$ & 0,64 & $0,75 *$ \\
& VC & $-1,16(0,85)$ & $5,43(3,39)$ & 0,28 & 0,51 \\
\hline \multirow{3}{*}{ Ibicatu } & FF & $-0,13(0,18)$ & $7,32(0,70)^{*}$ & $0,96 * *$ & $0,97 * *$ \\
& DAP & $-52,06(21,05)$ & $252,61(81,13)$ & 0,68 & $0,85 *$ \\
& ALT & $-28,38(6,51)^{*}$ & $149,65(25,08)^{* *}$ & $0,90^{* *}$ & $0,95 * *$ \\
& VC & $-1,64(0,99)$ & $7,22(3,83)$ & 0,39 & 0,69 \\
\hline \multirow{3}{*}{ Vassununga } & FF & $1,06(0,24)^{*}$ & $2,39(0,80)$ & 0,66 & $0,74^{*}$ \\
& DAP & $-17,91(2,52)^{* *}$ & $107,40(8,48)^{* *}$ & $0,97 * *$ & $0,98 * *$ \\
& ALT & $-5,62(2,34)$ & $56,39(7,87)^{* *}$ & $0,93 * *$ & $0,93 * *$ \\
& VC & $-0,85(0,21)$ & $3,76(0,72)^{*}$ & $0,87 *$ & $0,99 * *$ \\
\hline
\end{tabular}

${ }^{*}: P \leq 0,05 ; * *: P \leq 0,01$.

Tabela 38. Intercepto $(\hat{a})$, coeficiente de regressão $(\hat{b})$ e coeficiente de determinação para regressão linear $\left[\hat{r}^{2}\right.$ (Eq. linear)] e exponencial de $\left[\hat{r}^{2}\right.$ (Eq. exp.)] para os caracteres sobre o índice de fixação $(\hat{f})$, em três populações de $C$. legalis.

\begin{tabular}{|c|c|c|c|c|c|}
\hline Pop. & Caráter & $\hat{a}$ & $\hat{b}$ & $\hat{\boldsymbol{r}}^{2}$ (Eq. linear) & $\hat{r}^{2}$ (Eq. exp.) \\
\hline & $\mathrm{FF}$ & $3,25(0,28)^{* * *}$ & $-3,81(0,75)^{*}$ & $0,86 *$ & $0,92 * *$ \\
\hline \multirow[t]{3}{*}{ Campinas } & DAP & $46,27(9,17)^{*}$ & $-89,37(24,58) *$ & $0,75 *$ & $0,94 * *$ \\
\hline & ALT & $34,09(5,47) * *$ & $-63,90(14,66) *$ & $0,82 *$ & $0,94 * *$ \\
\hline & VC & $1,20(0,47)$ & $-2,68(1,27)$ & 0,46 & $0,87 *$ \\
\hline & FF & $3,01(0,21)^{* *}$ & $-3,65(0,62)^{* * *}$ & $0,89^{*}$ & $0,92 * *$ \\
\hline \multirow[t]{3}{*}{ Ibicatu } & DAP & $55,01(16,54) *$ & $-122,52(48,16)$ & 0,58 & $0,96 * *$ \\
\hline & ALT & $35,40(6,16)$ * & $-73,62(17,94)^{*}$ & $0,79 *$ & $0,96 * *$ \\
\hline & $\mathrm{VC}$ & $1,41(0,72)$ & $-3,49(2,09)$ & 0,31 & $0,98 * *$ \\
\hline & FF & $2,25(0,09) * *$ & $-1,61(0,27)^{* * *}$ & $0,90 * *$ & $0,91 * *$ \\
\hline \multirow[t]{3}{*}{ Vassununga } & DAP & $32,51(3,64) * *$ & $-62,69(11,34) *$ & $0,88 *$ & $0,98 * *$ \\
\hline & ALT & $21,39(0,87) * *$ & $-34,84(2,71)^{* * *}$ & $0,98 * *$ & $0,98 * *$ \\
\hline & $\mathrm{VC}$ & $0,87(0,24)^{*}$ & $-2,03(0,73)$ & 0,62 & $0,99 * *$ \\
\hline
\end{tabular}

${ }^{*}: P \leq 0,05 ; * *: P \leq 0,01$. 
Na Tabela 37 nota-se que o coeficiente de regressão $(\hat{b})$ dos caracteres sobre $\hat{H}_{o}$ foi significativo na população Campinas para o FF, Ibicatu para FF e ALT e Vassununga para DAP, ALT e VC. Assim, quanto maior a heterozigosidade, maior é o valor do caráter. Para estes casos, os coeficientes de determinação [ $\hat{r}^{2}$ (Eq. linear)] também foram expressivos, variando de valores moderados $(0,70)$ a altos $(0,97)$. A associação positiva entre caracteres e a heterozigosidade nas três populações é um forte indicativo de seleção contra homozigotos.

Por sua vez, na Tabela 38, observa-se que o coeficiente de regressão sobre 0 índice $\hat{f}$ foi negativo em todas as situações, sendo significativo na população Campinas e Vassununga para o FF, DAP e ALT e na população Ibicatu para o FF e ALT, mostrando que quanto menor é o índice $\hat{f}$, maiores são as médias dos caracteres. Da mesma forma que a situação anterior, o coeficiente $\hat{r}^{2}$ (Eq. linear) também foi maior nas situações de regressão significativa, variando, igualmente, de valores moderados $(0,75)$ a altos $(0,98)$. Estes resultados sugerem fortes evidências de depressão por endogamia nos ensaios, em especial na população Vassununga. Plantas com menor número de locos em heterozigose e maior endogamia apresentam menor desempenho para os caracteres e a seleção natural parece estar atuando contra a endogamia. Existem fortes evidências de seleção contra homozigotos entre a fase de plântula e a fase adulta em espécies arbóreas (Mitton \& Grant, 1980; Ledig et al., 1983; Strauss, 1987; Murawski et al., 1990; Murawsky \& Hamrick, 1992; Murawski \& Bawa, 1994; Sebbenn et al., 1998). Então, a seleção natural estaria favorecendo individuos com maior heterozigosidade e estes apresentariam vantagens adaptativas, o que, por sua vez, sugere a presença de sobredominância para locos adaptativos.

As associaçóes entre os caracteres e os índices de diversidade na Tabela 36, podem ser melhor visualizadas nas Figuras 4 a 9. O desempenho dos caracteres aumentou com o aumento das heterozigosidades e a redução do índice $\hat{f}$, nas classes e nas três populações. Observa-se também, um melhor ajuste das equações lineares na população Vassununga. Contudo, analisando-se os pontos nos gráficos, nota-se a tendência de uma distribuição não linear, mas sim, quadrática. 
$y=-0.211+9.153 x+\operatorname{eps}$

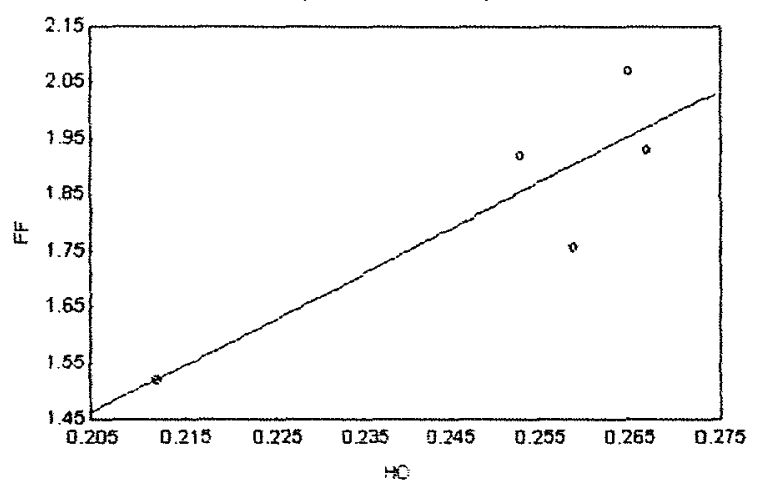

$y=-29592+135451 x+\operatorname{eps}$

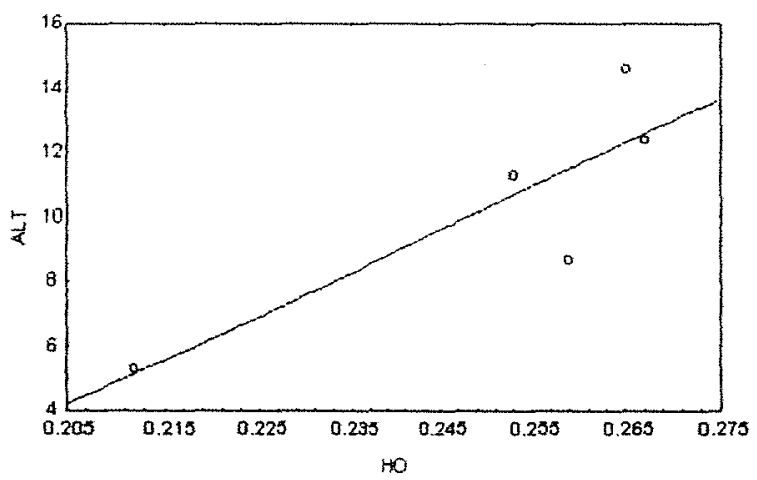

$y=-34.052+168.039 x+\operatorname{eps}$

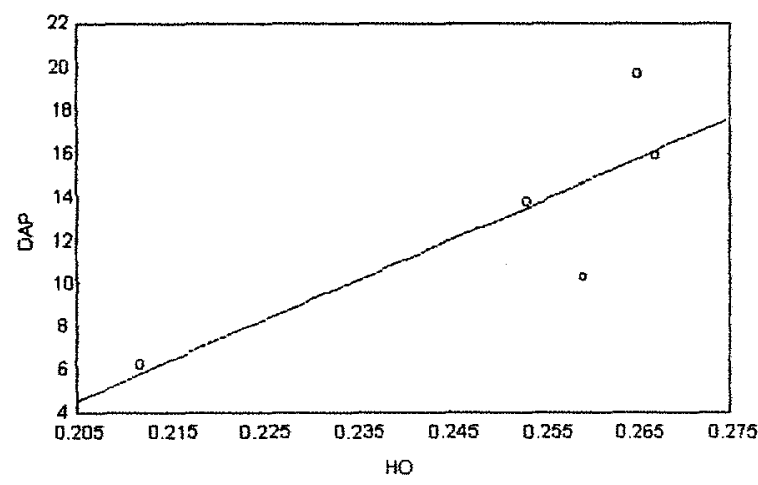

$y=-1.156+5.429 * x+e p s$

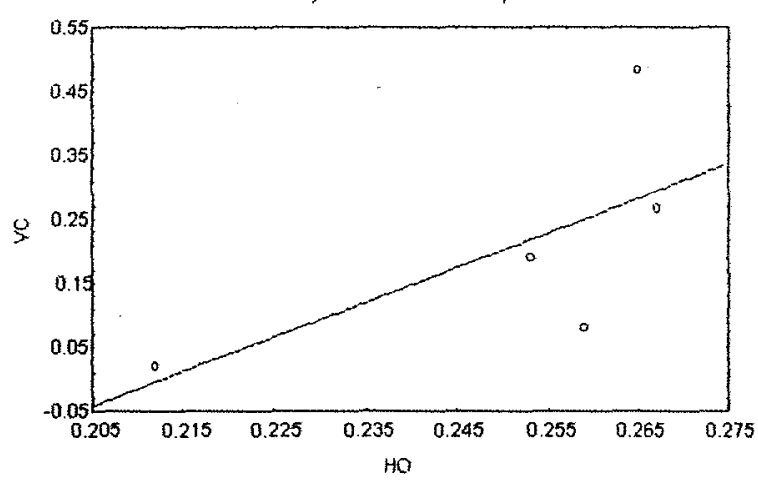

Figura 4 - Gráficos do fator de forma (FF), DAP, altura (ALT) e volume cilíndrico (VC) em função da heterozigosidade observada $\left(\hat{H}_{0}\right)$ na população Campinas de $C$. legalis. 
$y=-0.128+7.322 x+\operatorname{eps}$

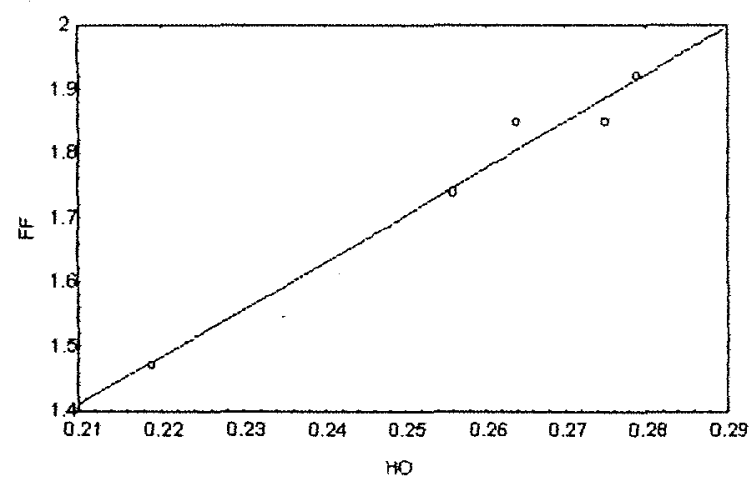

$y=-28.388+149.652^{*} x+205$

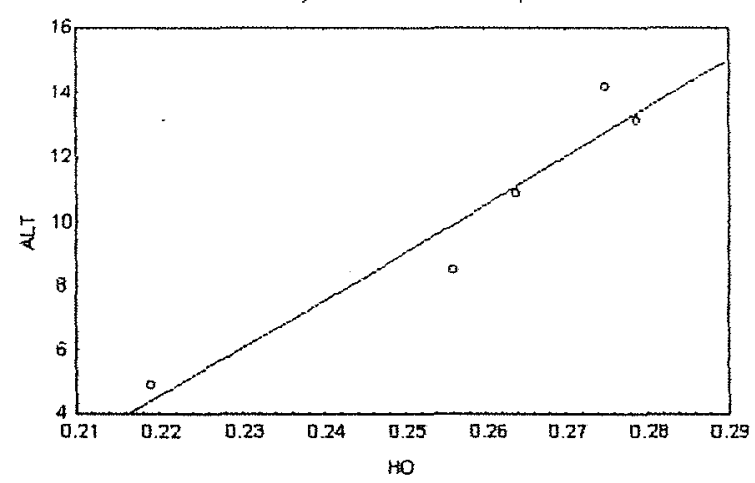

$y=-52.063+252.61 x+\operatorname{eps}$

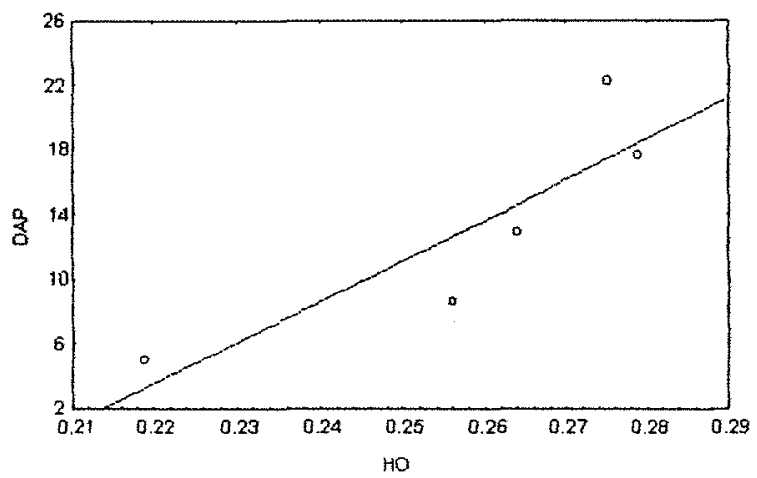

10

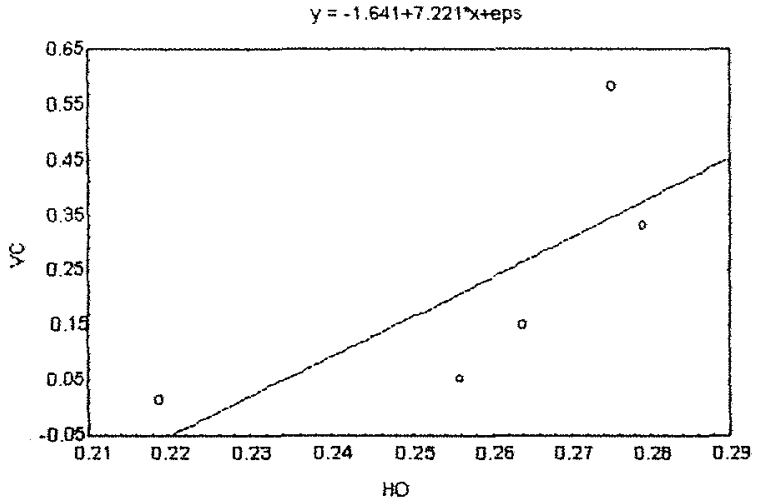

Figura 5 - Gráficos do fator de forma (FF), DAP, altura (ALT) e volume cilíndrico (VC) em função da heterozigosidade observada $\left(\hat{H}_{o}\right)$ na população Ibicatu de C. legalis. 

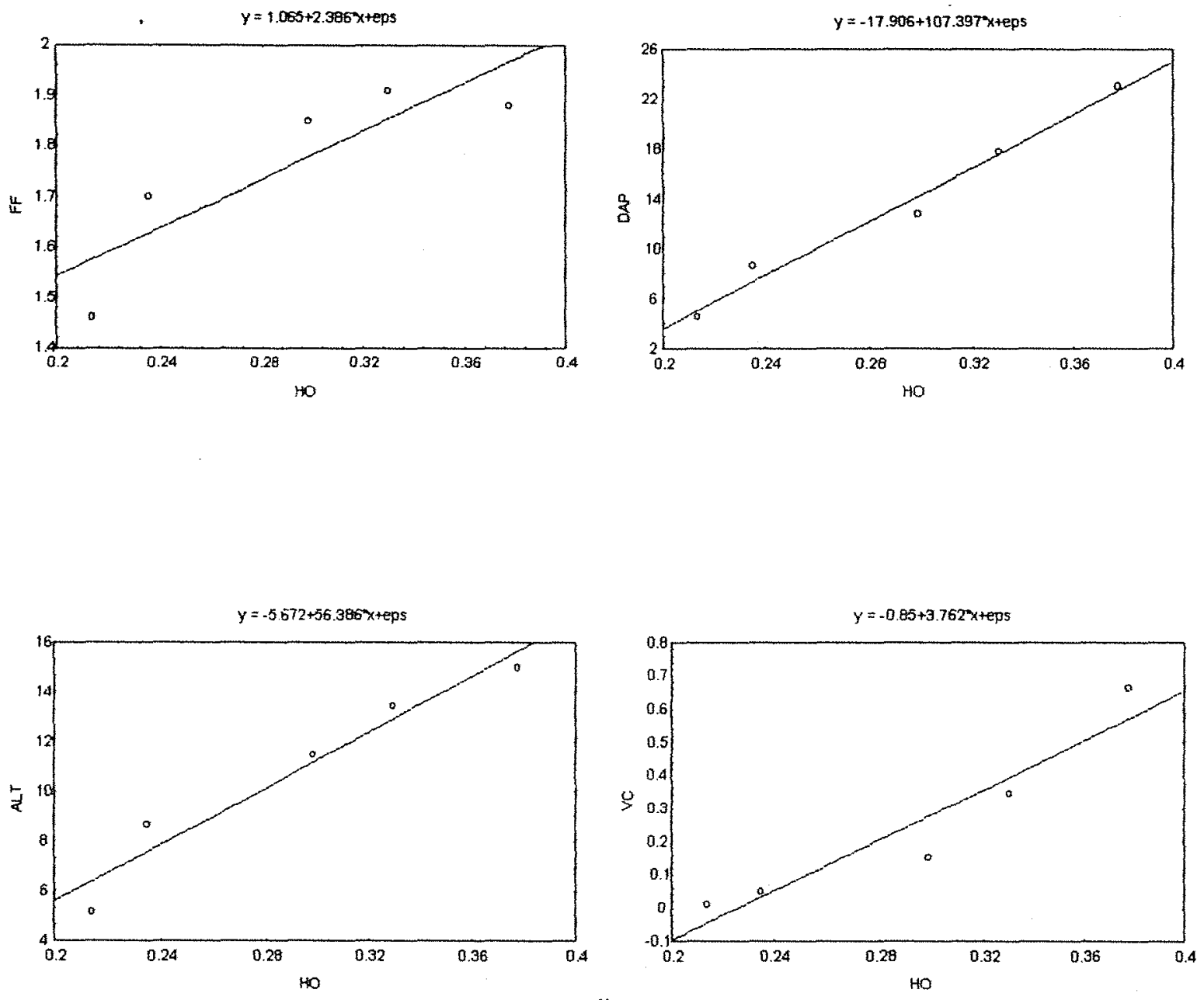

Figura 6 - Gráficos do fator de forma (FF), DAP, altura (ALT) e volume cilíndrico (VC) em função da heterozigosidade observada $\left(\hat{H}_{o}\right)$ na população Vassununga de $C$. legalis. 

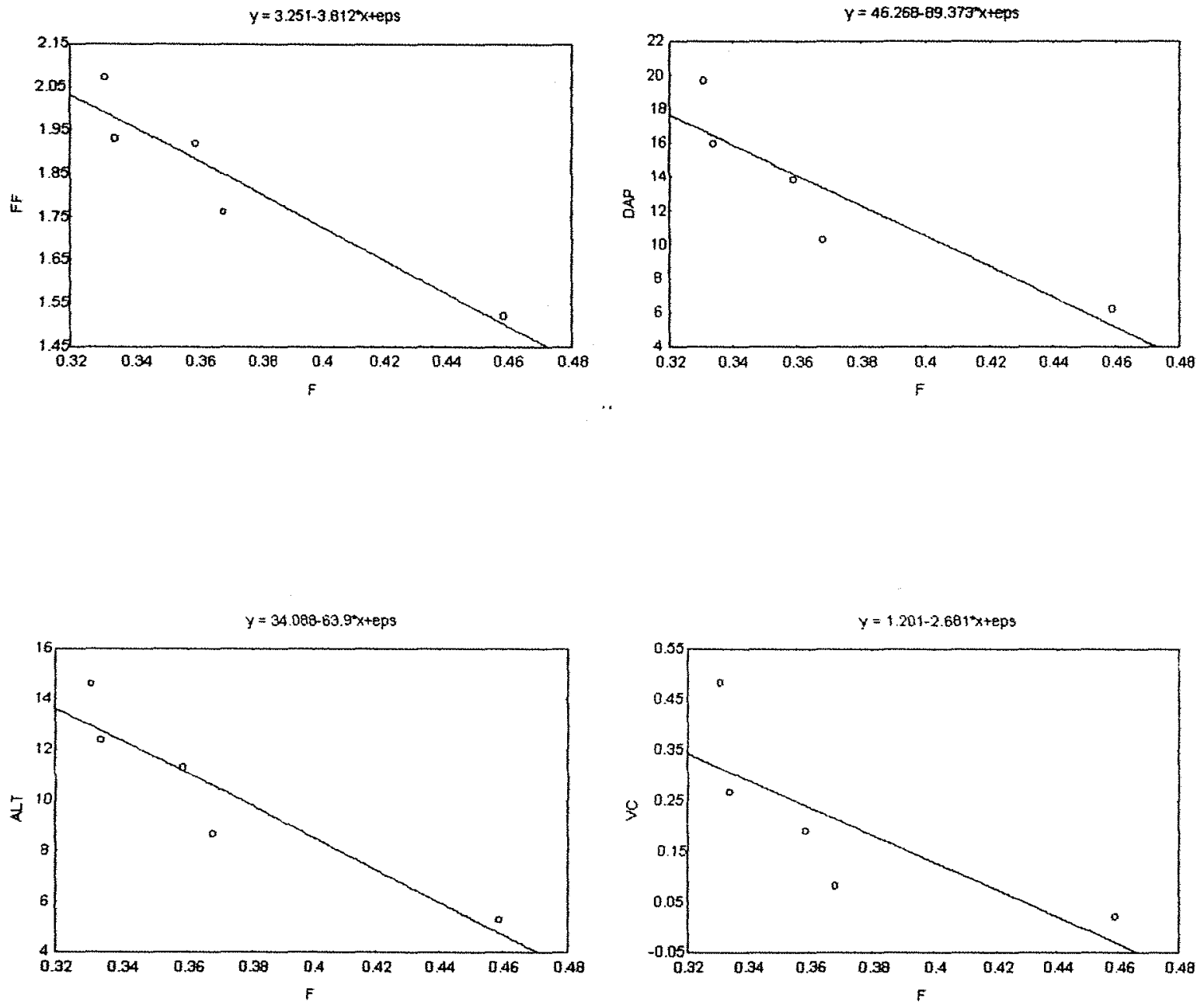

Figura 7 - Gráficos do fator de forma (FF), DAP, altura (ALT) e volume cilíndrico (VC) em função do índice de fixação $(\hat{f})$ na população Campinas de C. legalis. 

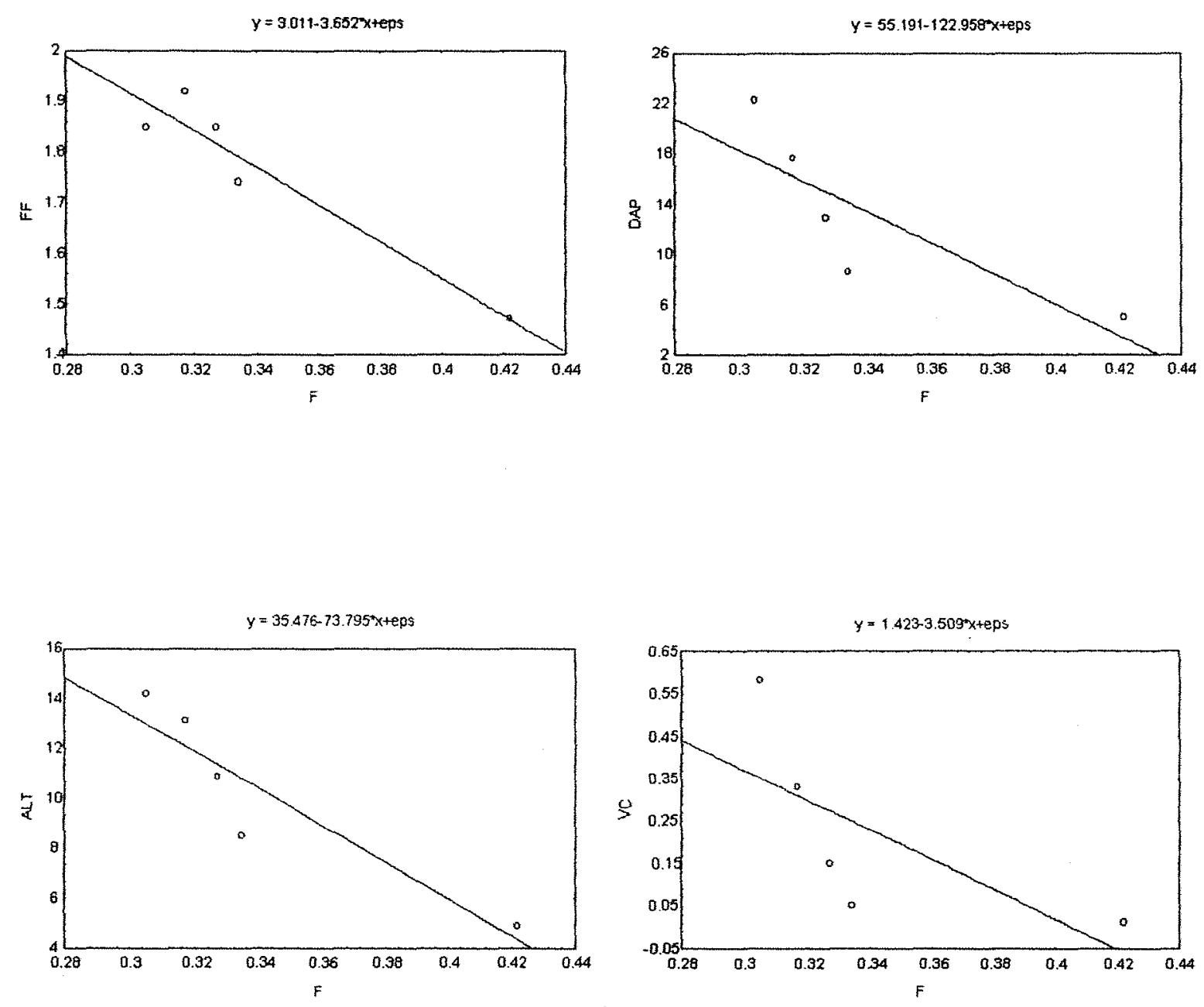

Figura 8 - Gráficos do fator de forma (FF), DAP, altura (ALT) e voluma cilíndrico (VC) em função do índice de fixação $(\hat{f})$ na população Ibicatu de C. legalis. 

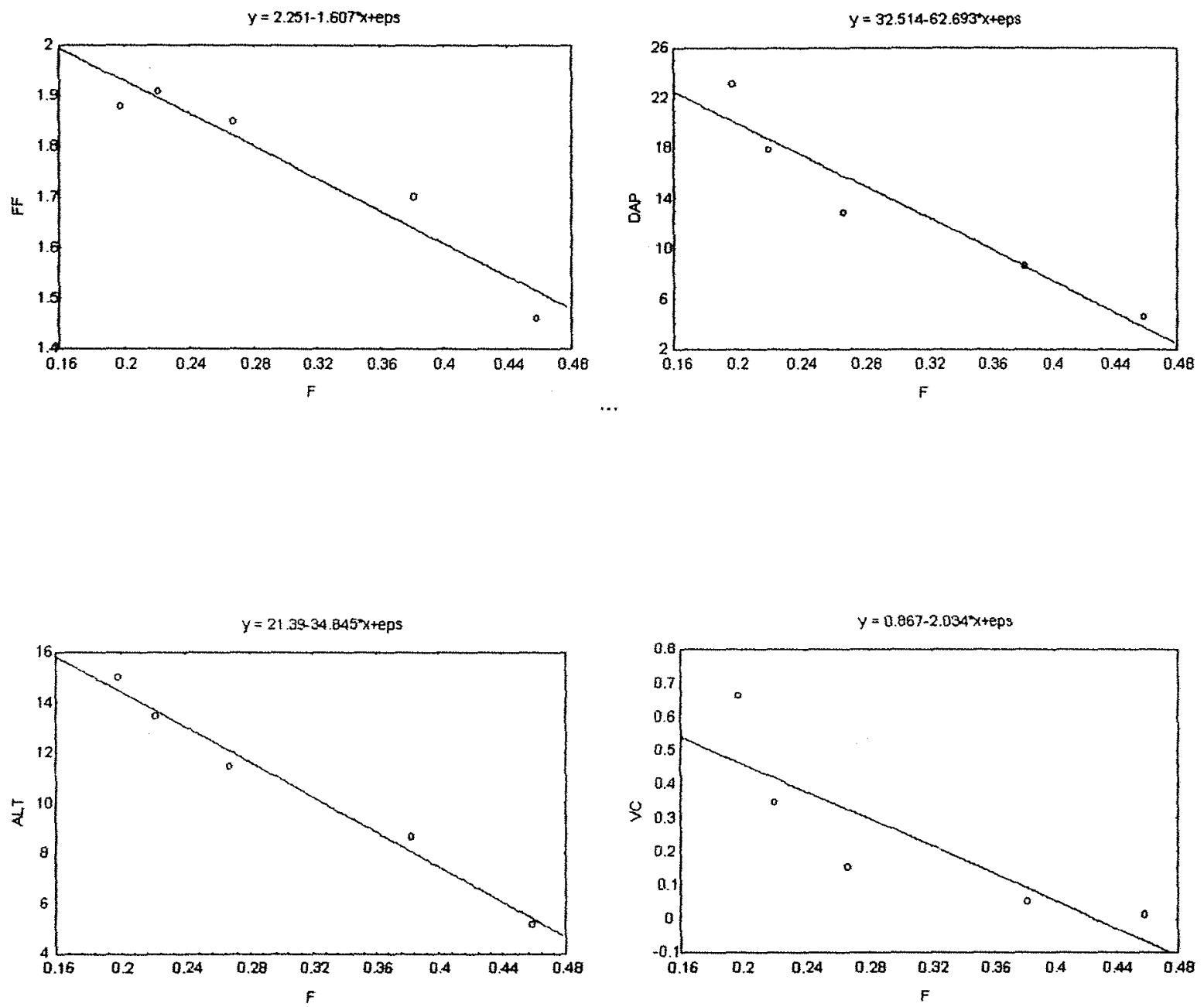

Figura 9 - Gráficos do fator de forma (FF), DAP, altura (ALT) e volume cilíndrico (VC) em função do índice de fixaçao $(\hat{f})$ na população Vassununga de $C$. legalis. 
O ajuste às equações não lineares revelaram altos e significativos coeficientes de determinação [ $\hat{r}^{2}$ (Eq. exp.)] para quase todos os caracteres, nas populaçð̃es, em especial para o coeficiente de endogamia $\left(\hat{r}^{2}\right.$ mínimo $\left.=0,87\right)$. Portanto, a herança da depressão por endogamia, nas populações de $C$. legalis, não é causada somente por efeitos sobredominantes ou por genes detrimentais, mas sim, também por efeitos epistáticos, complicando a avaliação da herança da depressão por endogamia, na espécie.

A regressão significativa observada nos caracteres sobre a heterozigosidade e indice de fixação podem ser explicadas por duas hipótese: primeiro, sugere-se que as isoenzimas estão sofrendo seleção, ou estão fortemente associadas a locos que determinam a expressão dos caracteres em estudo; segundo, elas descrevem o comportamento do sistema de reprodução, ou seja, os índivíduos de pior desempenho seriam o resultado de autofecundações ou cruzamentos entre parentes e os de melhor seriam o resultado de cruzamentos entre indivíduos não aparentados. A última hipótese parece ser a mais provável, considerando a natureza presumivelmente neutra das isoenzimas e devido a deteç̧ão de $2,4 \%$ de autofecundação na população Ibicatu e 9,9\% na Vassununga, e mais, $9,1 \%$ de cruzamento entre parentes na população Campinas, $5,9 \%$ na Ibicatu e $7 \%$ na Vassununga.

Testou-se a hipótese de seleção, avaliando-se as diferenças nas freqüências alélicas entre as cinco classes fenotípicas em cada população, por análise de variância de freqüências alélicas (Weir, 1996), considerando-se as classes como subpopulações (Tabela 39). A deteç̧ão de diferenças significativas entre as freqüências alélicas dos grupos pode sugerir homogeneidade nas freqüências alélicas dentro dos grupos, logo que a seleção esteja favorecendo alelos específicos.

Os resultados mostraram baixa divergência genética entre as classes para todos os locos e média sobre locos nas três populações $(<1 \%)$. A significância para as populações Campinas e Vassununga ocorreu devido à consistência nos valores entre locos, levando a uma baixa variância e desvio padrão entre locos, porém, devido às suas magnitudes, podem ser consideradas negligiveis. A partir disso, pode-se supor que não ocorreu seleção para alelos específicos e o marcador comportou-se como neutro, podendo-se atribuir a redução no desempenho dos caracteres, com o aumento no índice de fixação ao sistema 
de reprodução. Os indivíduos gerados por autofecundação e por cruzamento entre parentes têm um número maior de locos em homozigose do que individuos gerados por cruzamentos entre árvores não aparentadas, o que é refletido no índice de fixação. Assim, a endogamia ou aumento da homozigose, gerada por autofecundação e cruzamento entre parentes, afeta o genoma das plantas como um todo, ou seja, tanto genes que sofrem seleção (adaptativos) como genes neutros e os resultados observados, não são nada mais do que o reflexo destas formas de reprodução.

Tabela 39. Divergência genética entre classes de distribuição de caracteres quantitativos $\left(\hat{\theta}_{a}\right)$ para três populações de C. legalis.

\begin{tabular}{|c|c|c|c|}
\hline Loco & Pop. Campinas & Pop. Ibicatu & Pop. Vassununga \\
\hline Acp 3 & 0,004 & 0,000 & 0,022 \\
\hline Est-1 & 0,007 & 0,000 & 0,000 \\
\hline Est-2 & 0,043 & 0,011 & 0,020 \\
\hline Pgi-1 & 0,000 & 0,000 & 0,014 \\
\hline Pgi-2 & 0,002 & 0,000 & 0,000 \\
\hline Mdh-1 & 0,000 & 0,000 & 0,004 \\
\hline Mdh-2 & 0,001 & 0,000 & 0,006 \\
\hline Prx-1 & 0,000 & 0,003 & 0,000 \\
\hline Prx-2 & 0,000 & 0,005 & 0,007 \\
\hline Prx-3 & 0,008 & 0,001 & 0,002 \\
\hline 6Pgdh-1 & 0,005 & 0,002 & 0,000 \\
\hline Skdh-1 & 0,004 & 0,010 & 0,007 \\
\hline G6pdh-1 & 0,007 & 0,000 & 0,000 \\
\hline Idh-1 & 0,013 & 0,000 & 0,029 \\
\hline Média & $\begin{array}{c}0,006 \\
(0,000 \text { a } 0,015)\end{array}$ & $\begin{array}{c}0,001 \\
(-0,003 \text { a } 0,004)\end{array}$ & $\begin{array}{c}0,007 \\
(0,002 \mathrm{a} 0,012)\end{array}$ \\
\hline
\end{tabular}

(): Intervalo de confiança a $95 \%$ de probabilidade, estimado por 10.000 reamostragens boodstrap.

As estimativas da depressão por endogamia $(\hat{\delta})$ para os caracteres nas três populações são apresentadas na Tabela 40 . Vale ressaltar que as estimativas apresentadas são válidas para os intervalos de classes do índice fixação apresentados entre parênteses na Tabela 40, não sendo válidas para valores inferiores e superiores a estes intervalos, devido à falta de ajuste da equação de regressão linear. 
Tabela 40 . Depressão por endogamia em percentual $(\hat{\delta})$ em caracteres quantitativos, para classes de fixação de alelos observadas nas populações de C. legalis.

\begin{tabular}{cccc}
\hline Caracteres & $\begin{array}{c}\text { Pop. Campinas } \\
(0,331 \text { a 0,459) }\end{array}$ & $\begin{array}{c}\text { Pop. Ibicatu } \\
(0,305 \text { a 0,422) }\end{array}$ & $\begin{array}{c}\text { Pop.Vassununga } \\
(0,198 \text { a 0,459) }\end{array}$ \\
\hline FF & 26,6 & 20,5 & 22,3 \\
DAP $(\mathrm{cm})$ & 68,2 & 77,86 & 80,2 \\
ALT (m) & 63,7 & 65,5 & 65,6 \\
VC $\left(\mathrm{m}^{3}\right)$ & 95,9 & 97,9 & 98,5 \\
\hline
\end{tabular}

() Valor minimo e máximo de $\hat{f}$ apresentado para a população.

Os resultados revelaram altas taxas de depressão por endogamia para os caracteres na espécie. $O$ volume cilindrico foi o caráter que apresentou os maiores valores $(90 \%)$ e a forma do fuste os menores $(<27 \%$ ). Como o vohume cilíndrico é um caráter estimado a partir do DAP e da altura, e estes apresentaram valores individuais de depressão alta, era esperada maior depressão para o VC. Durel et al. (1990) estudando Pinus pinaste aos 10 anos de idade e Griffin \& Cotterill (1988) estudando Eucalyptus regnans aos 3 anos também observaram maiores valores de depressão por endogamia para o volume cilíndrico (63 e 37\%, respectivamente), em relação a outros caracteres de crescimento. O DAP apresentou níveis de depressão um pouco superiores à altura nas três populações, sugerindo que este caráter é mais susceptível à expressão da endogamia. Este mesmo comportamento foi relatado por Geburek (1986) para Picea omorika, Griffin \& Cotterill (1988) para Eucalyptus regnans, Durel et al. (1990) para Pinus pinaste e Sorensen (1997) para Pseudotsuga menzienssii, aumentando a probabilidade desta hipótese estar correta.

Em relação às populações, de modo geral, a população Vassununga revelou os maiores níveis de depressão, seguida da população Ibicatu e finalmente da Campinas. $O$ comportamento da depressão por endogamia nas populações agrega-se à magnitude das taxas de autofecundação detectadas nestas populações, onde Vassununga, Ioicatu e Campinas apresentaram valores de 9,9, 2,4 0,1\% de autofecundação, respectivamente. Em contraste, a taxa de cruzamento entre parentes foi de 9,1,5,9 e 7,0\%, para estas populações, respectivamente. Parece que a autofecundação foi a principal causa da depressão por endogamia, em concordância com as predições teóricas propostas por 
Allard (1971), o qual afirma que a autofecundação é uma forma mais drástica de gerar endogamia do que o cruzamento entre parentes, portanto também depressão por endogamia.

Os valores de depressão por endogamia aqui observados são superiores aos relatados na literatura. Isto pode possivelmente estar associado à idade de avaliação do experimento. Tałvez, se a avaliação tivesse sido realizada em idades mais precoces, os valores teriam sido inferiores. Vários estudos têm observado que a depressão por endogamia aumenta com o aumento da idade das plantas, podendo-se citar os trabalhos de Libby et al. (1981), Sorensen \& Miles (1982), Geburek (1986). Uma resposta mais precisa sobre este ponto só é possível através de um estudo mais detalhado.

A constatação de que $C$. legalis apresenta forte depressão por endogamia para caracteres de crescimento, tem implicações nas estratégias de recuperação de áreas degradas, conservação e melhoramento genético.

A recuperação de áreas degradadas e alteradas à partir de sementes coletadas de polinização livre, em populações naturais de $C$. legalis, pode levar à redução na capacidade adaptativa, reprodutiva, evolutiva e produtiva, caso algumas medidas para minimizar a endogamia, no material coletado, não sejam tomadas. Primeiro, é importante que as sementes para estes fins sejam coletadas de um número grande de árvores ( 50 ), distanciadas entre si por uma ou algumas centenas de metros. Esta forma de coleta permite reduzir a probabilidade de parentesco entre árvores matrizes, fontes das sementes, aumentando o potencial evolutivo, adaptativo e reprodutivo da espécie nos locais de recuperação. Contudo, esta prática não evita que sementes endogâmicas oriundas de autofecundação e do cruzamento entre parentes sejam excluídas do conjunto gênico. É provável que as sementes endogâmicas sejam em maior parte eliminadas durante a fase de germinação e período de viveiro. Segundo, na fase de viveiro, selecionar para o plantio somente mudas que apresentem boa constituição, colaborando assim, para a eliminação de sementes endogâmicas. Terceiro, deve ser praticado o controle gamético feminino, incluindo-se no conjunto de sementes a mesma quantidade por matriz, estratégia esta que permite maximizar o tamanho efetivo das populações, portanto ampliar seu potencial adaptativo e evolutivo. Quarto, na impossibilidade de coleta de sementes de um grande número de árvores matrizes, não misturar as sementes, mas sim, manter sua identidade, 
plantando os indivíduos em grupos compostos de diferentes origens maternas. Esta última recomendação, apesar de aumentar os custos da recuperação, podem minimizar o aparecimento de endogamia futura e, portanto, de seus efeitos, a depressão por endogamia, mantendo um certo potencial adaptativo e produtivo na espécie.

Do ponto de vista de conservação genética ex situ, a depressão observada prediz que indivíduos mais endogâmicos encontram-se dominados nos ensaios, sendo possível que estes venham a morrer antes dos indivíduos dominantes. Contudo, se a hipótese do menor crescimento realmente estiver associada à presença de genes deletérios nas populações, é desejável que estes indivíduos sejam eliminados do banco, antes da espécie entrar em fase de reprodução, caso contrário, durante o processo de recombinação muito destes genes serão transferidos para as próximas gerações. A conservação de genes detrimentais em alta freqüência pode por em risco a manutenção do banco a longo prazo, bem como reduzir seu valor como fonte de sementes para o reflorestamento.

Para o melhoramento, a depressão observada tem menor importância, dado que, se os ensaios forem submetidos à seleção, visando a sua transformação em "pomares de sementes por mudas", uma boa parte da carga genética das populações será eliminada, juntamente com os indivíduos endogâmicos. Outra parte, contudo, provavelmente em menor freqüência, será mantida em estado de heterozigose, a qual poderá ser eliminada parcialmente em ciclos seletivos subseqlientes. 


\subsection{Progressos Na SEleÇÃo}

\subsubsection{Coeficientes dos Componentes Quadráticos}

Os coeficientes dos componentes quadráticos foram estimados para as progênies de cada população considerando-se a $C$. legalis como de reprodução mista. Os coeficientes de parentesco multiplicadores dos componentes da $\hat{\sigma}_{A}^{2}, \hat{\sigma}_{D}^{2}, \hat{D}_{1}, \hat{D}_{2}$ e $\hat{\delta}$ são apresentados na Tabela 41.

Tabela 41. Coeficiente de parentesco $\left(\hat{r}_{x y}\right)$, dominância $\left(\hat{\mu}_{x y}\right)$, covariância de efeitos aditivos e de dominância dos homozigotos $\left(\hat{\vartheta}_{x y}\right)$, variância dos efeitos de dominância dos homozigotos $\left(\hat{\omega}_{x y}\right)$ e depressão por endogamia $\left(\hat{\gamma}_{x y}\right)$ para progênies de reprodução mista em três populações de C. legalis.

\begin{tabular}{ccccccc}
\hline Coeficiente & \multicolumn{2}{c}{ Pop. Campinas } & \multicolumn{2}{c}{ Pop. Ibicatu } & \multicolumn{2}{c}{ Pop.Vassununga } \\
\hline$\hat{r}_{x y}$ & 0,3347 & $-\cdots$ & 0,3331 & -- & 0,3470 &.- \\
$\hat{\mu}_{x y}$ & 0,0797 & $4,2^{\mathrm{a}}$ & 0,0711 & 4,7 & 0,0475 & 7,3 \\
$\hat{\vartheta}_{x y}$ & 0,0055 & $60,8^{\mathrm{b}}$ & 0,0134 & 24,8 & 0,0578 & 6,0 \\
$\hat{\omega}_{x y}$ & 0,0000 & $33470^{\mathrm{c}}$ & 0,0000 & 33310 & 0,0000 & 3470 \\
$\hat{\gamma}_{x y}$ & 0,0001 & $3347^{\mathrm{d}}$ & 0,0003 & 1110,3 & 0,0021 & 165,2 \\
\hline $\mathrm{a}: \hat{r}_{x y} / \hat{\mu}_{x y} ; \mathrm{b}: \hat{r}_{x y} / \hat{\vartheta}{ }_{x y} ; \mathrm{c:}: \hat{r}_{x y} / \hat{\omega}_{x y} ; \mathrm{d}: \hat{r}_{x y} / \hat{\gamma}_{x y}{ }^{*}$ & & & &
\end{tabular}

$O$ coeficiente multiplicador da variância aditiva $\left(\hat{r}_{x y}\right)$ foi maior nas três populações, seguido do coeficiente de dominância $\left(\hat{\mu}_{x y}\right)$ e de covariância de efeitos aditivos e de dominância dos homozigotos $\left(\hat{\vartheta}_{x y}\right)$. Os coeficientes multiplicadores da variância de dominância dos homozigotos $\left(\hat{\omega}_{x y}\right)$ e da depressão por endogamia $\left(\hat{\gamma}_{x y}\right)$ foram praticamente nulos, sugerindo que a contribuição destes componentes para a variância genética entre progênies é muito baixo ou até nulo no material genético em estudo. A relação entre $\hat{r}_{x y} / \hat{\mu}_{x y}$ foi de $4,2,4,7$ e 7,3 e $\hat{\mu}_{x y} / \hat{\vartheta}_{x y}$ foi de $14,5,5,3$ e 0,8 , para a população Campinas, Ibicatu e Vassununga, respectivamente. Isto mostra que a 
variância genética aditiva $\left(\hat{\sigma}_{A}^{2}\right)$ é o principal componente responsável pela herança dos caracteres, mesmo quando a taxa de autofecundação é alta $(9,9 \%$ - Vassununga). A variância genética de dominância $\left(\hat{\sigma}_{D}^{2}\right)$ teria que ser 4,2 vezes maior que a variância aditiva para ter uma contribuição igual para a variância genética entre progênies $\left(\hat{\sigma}_{f}^{2}\right)$. Avaliando-se a Tabela 61 (anexos), observa-se que a $\hat{\sigma}_{D}^{2}$ tem muitas vezes contribuído mais para a $\hat{\sigma}_{f}^{2}$ do a $\hat{\sigma}_{A}^{2}$, chegando a contribuir com até $78,3 \%$, para o caso do caráter DAP em Picea abies (Silva et al., 2000). Mas para a média das espécies florestais, considerando o caráter DAP, a contribuição da $\hat{\sigma}_{A}^{2}$ foi de $57,1 \%$ e a $\hat{\sigma}_{D}^{2}$ de $42,9 \%$, o que, ponderado pelos seus respectivos coeficientes de parentesco, revelam que a variância aditiva é o componente mais importante para a $\hat{\sigma}_{f}^{2}$.

As covariâncias entre os efeitos aditivos e dominância parecem ter importância somente no caso de taxas altas de autofecundação, sendo, aparentemente mais pronunciados seus efeitos do que o da $\hat{\sigma}_{D}^{2}$, como observado para o caso da população Vassununga, em que $\hat{\vartheta}_{x y}$ foi maior que $\hat{\mu}_{x y}$. A depressão por endogamia passa a ter uma maior contribuição para a covariância genética entre progênies quando a taxa de autofecundação $(s)$ aumenta, como pode ser visto para o caso da população Vassununga, mas mesmo assim, sua contribuição foi baixa se comparada à $\hat{\sigma}_{A}^{2}$.

Em resumo, conclui-se que, em qualquer das situações aqui em estudo, nas taxas de autofecundações entre 0 e $10 \%$, a $\hat{\sigma}_{A}^{2}$ é o componente que mais contribuíu para a $\hat{\sigma}_{f}^{2}$, portanto para a herança dos caracteres. Contudo, de acordo com a Tabela 60 , a variância de dominância é importante para a $\hat{\sigma}_{f}^{2}$ e como essa não está sendo considerada nas estimativas dos parâmetros genéticos, são esperados erros nas estimativas de ganhos genéticos, mesmos com a correção realizada no coeficiente de parentesco $\left(\hat{r}_{x y}\right)$ multiplicador da $\hat{\sigma}_{A}^{2}$. É provável que tais erros não sejam graves, dado que a proporção máxima de irmãos completos detectados foi de $32,4 \%$ das progênies de cruzamento na 
população Campinas e a proporção máxima de individuos de autofecundação foi de $10 \%$ (Vassununga), sendo a proporção de meios irmãos maior nas progênies.

As estimativas obtidas da $\hat{\sigma}_{A}^{2}$, pelo método de Ritland (1989), não são precisas, mas como a $C$. legalis é predominantemente de sistema misto, acredita-se que estas estimativas são mais realistas do que as obtidas considerando a espécie como de cruzamentos aleatórios (meios irmãos). Vale ressaltar que o coeficiente de parentesco $\left(\hat{r}_{x y}\right)$ estimado entre os indivíduos dentro de progênies, apresentou-se superior ao esperado em progênies de meios irmãos (1/4) e similar ao sugerido por Franklin (1974) e Hamrick (1976), para espécies de reprodução mista ( $1 / 3$ ).

Ainda, é possível utilizar a estimativa de $\hat{\theta}_{F}$ individual de cada população, como estimador de $\hat{r}_{x y}$ na expressão 133 , assim, $\hat{r}_{x y}=2 \hat{\theta}_{F}$. Em progênies de meios irmãos, como já comentado, $\hat{\theta}_{F}$ corresponde a 0,125 , tendendo a crescer em progênies de reprodução mista com o aumento da proporção de irmãos completos e indivíduos de autofecundação. A adoção do índice $\hat{\theta}_{F}$, para a estimativa da $\hat{\sigma}_{A}^{2}$, resulta em estimativas menos precisas do que as obtidas pelo método de Ritland (1989), por não ponderar com precisão a proporção de indivíduos de autofecundação, irmãos completos e meios irmãos, a taxa de autofecundação e o coeficiente de endogamia da geração parental.

\subsubsection{Variância Genética Aditiva}

A variância genética aditiva $\left(\hat{\sigma}_{A}^{2}\right)$ foi estimada para três situações (Tabela 42 ): primeiro, considerando as progênies de $C$. legalis como meios irmãos, sem parentesco e endogamia na geração parental (MI); segundo, considerando as progênies como misturas de meios irmãos, irmãos completos e indivíduos de autofecundação, com parentesco e sem endogamia na geração parental (MS; $\hat{\theta} \neq 0$ ) e; terceiro considerando as progênies como misturas de meio irmãos, irmãos completos e indivíduos de autofecundação, mas sem parentesco e endogamia na geração parental (MS; $\hat{\theta}=0)$. 
Tabela 42. Estimativas da variância genética aditiva $\left(\hat{\sigma}_{A}^{2}\right)$ para quatro caracteres em três populações de $C$. legalis em dois locais de ensaio, considerando a espécie como meios irmãos $(\mathrm{MI})$, de reprodução mista com parentesco $(\mathrm{MS} ; \hat{\theta} \neq 0)$ e sem parentesco na geração parental $(\mathrm{MS} ; \hat{\theta}=0)$.

\begin{tabular}{|c|c|c|c|c|c|c|c|}
\hline \multirow[b]{2}{*}{ Caráter } & \multirow[b]{2}{*}{ Pop. } & \multicolumn{3}{|c|}{ E. E. Luiz Antonio } & \multicolumn{3}{|c|}{ E. E. Pederneiras } \\
\hline & & MI & $\mathrm{MS} ; \hat{\theta} \neq 0$ & MS; $\hat{\theta}=0$ & MI & MS; $; \hat{\theta} \neq 0$ & $\mathrm{MS} ; \hat{\theta}=0$ \\
\hline \multirow{3}{*}{ FF } & Campinas & 0,0013 & 0,0011 & 0,0010 & 0,0071 & 0,0057 & 0,0053 \\
\hline & Ibicatu & 0,0433 & 0,0349 & 0,0325 & 0,0074 & 0,0060 & 0,0056 \\
\hline & Vassununga & 0,0040 & 0,0031 & 0,0029 & 0,0110 & 0,0084 & 0,0079 \\
\hline \multirow{3}{*}{ DAP } & Campinas & 3,0772 & 2,4677 & 2,2982 & 2,6950 & 2,1612 & 2,0127 \\
\hline & Ibicatu & 3,5936 & 2,8971 & 2,6971 & 0,7600 & 0,6127 & 0,5704 \\
\hline & Vassunumga & 2,2464 & 1,7331 & 1,6183 & 1,5204 & 1,1731 & 1,0953 \\
\hline \multirow{3}{*}{ Altura } & Campinas & 0,5381 & 0,4315 & 0,4019 & 0,5711 & 0,4580 & 0,4265 \\
\hline & Tbicatu & 3,3631 & 2,7113 & 2,5241 & 0,3053 & 0,2462 & 0,2292 \\
\hline & Vassununga & 0,2534 & 0,1955 & 0,1826 & 1,3550 & 1,0454 & 0,9761 \\
\hline \multirow{3}{*}{$\mathrm{VC}$} & Campinas & 0,0048 & 0,0038 & 0,0036 & 0,0016 & 0,0013 & 0,0012 \\
\hline & Ibicatu & 0,0043 & 0,0035 & 0,0033 & 0,0000 & 0,0000 & 0,0000 \\
\hline & Vassununga & 0,0034 & 0,0026 & 0,0025 & 0,0013 & 0,0010 & 0,0009 \\
\hline
\end{tabular}

Observa-se uma redução substancial na magnitude das estimativas da $\hat{\sigma}_{A}^{2}$ quando se considera a espécie como de reprodução mista com e sem parentesco na geração parental, em relação à alogamia perfeita. A redução foi aproximadamente igual para todos os caracteres em nível de populações, nos dois locais, ou seja, 19,0\% para a população Campinas e Ibicatu e $22 \%$ para Vassununga, quando se considera o parentesco e 25,0\% para a população Campinas e Ibicatu e $27 \%$ para Vassununga, na ausência de parentesco (anexos: Tabela 61). Nota-se que esta redução não foi causada exclusivamente pela taxa de autofecundação, sendo que as correlações de autofecundação $\left(\hat{r}_{s}\right)$ e de paternidade $\left(\hat{r}_{p}\right)$ também contribuíram, porém em menor proporção. A proporção de irmãos completos e indivíduos de autofecundação têm importância chave na determinação da 
$\hat{\sigma}_{A}^{2}$, por redistribuir uma maior proporção desta variação entre progênies e reduzir dentro de progênies.

A inclusão do coeficiente de parentesco corrige a estimativa da $\hat{\sigma}_{A}^{2}$ para uma taxa menor do que a estimativa realizada sem sua consideração. A diferença na superestimativa da $\hat{\sigma}_{A}^{2}$ em progênies de reprodução mista com e sem parentesco entre genitores foi de aproximadamente $6 \%$. $O$ parentesco reduz a estimativa da $\hat{\sigma}_{A}^{2}$ entre os genitores e conseqūentemente entre suas progênies. No caso de progênies de meios irmão, se existir parentesco na geração parental, a estimativa da $\hat{\sigma}_{A}^{2}$ será menor do que seria esperado se não existisse. Por isso, em progênies de reprodução mista mas com parentesco entre genitores a superestimativa na variância genética aditiva é menor do que se não houvesse parentesco ou, em outras palavras, o erro cometido na estimativa da $\hat{\sigma}_{A}^{2}$ será menor. Este fenômeno já havia sido relatado por Squillace (1974) e Surles et al. (1990).

\subsubsection{Coeficientes de Herdabilidade}

Nas Tabelas 43 e 44 são apresentados os coeficientes de herdabilidade estimados admitindo-se que as progênies de polinização aberta foram geradas por cruzamentos aleatórios $(\mathrm{MI})$, sendo sua relação de parentesco de meios irmãos, e como de reprodução mista com parentesco (MS; $\hat{\theta} \neq 0$ ) e sem parentesco (MS; $\hat{\theta}=0)$ na geração parental.

As estimativas da $\hat{\sigma}_{A}^{2}$ admitindo-se o sistema misto com e sem parentesco na geração parental causaram reduções nos coeficientes de herdabilidades. Apesar da magnitude das herdabilidades serem relativamente baixas para os caracteres, estes encontram-se superestimados, como pode ser verificado comparando-se os valores obtidos, admitindo-se que as progênies são meios irmãos e que existem diferentes graus de parentesco dentro das progênies. A redução nas estimativas está associada ao efeito de população e nível de estimativa, ou seja, progênies, dentro de progênies, sub-parcela, bloco e plantas individuais, mas não a efeito de caracteres e locais. Portanto, o sistema de reprodução influenciou igual e simultaneamente todos os caracteres, em ambos os locais de ensaio. Este resultado é de fácil compreensão. Primeiro, a redução diferenciada entre 
言 長賚

委

的

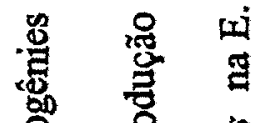

윰 总

苞 导

요

ษ 总

爵 ह

ㅇ g

․ㄹㄹ 鸹

ชั

告

㟒

8 遭

总 志 豆

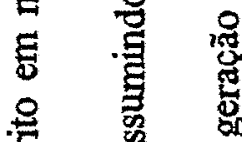

莺 莺

兽 正

을 률

胥

을

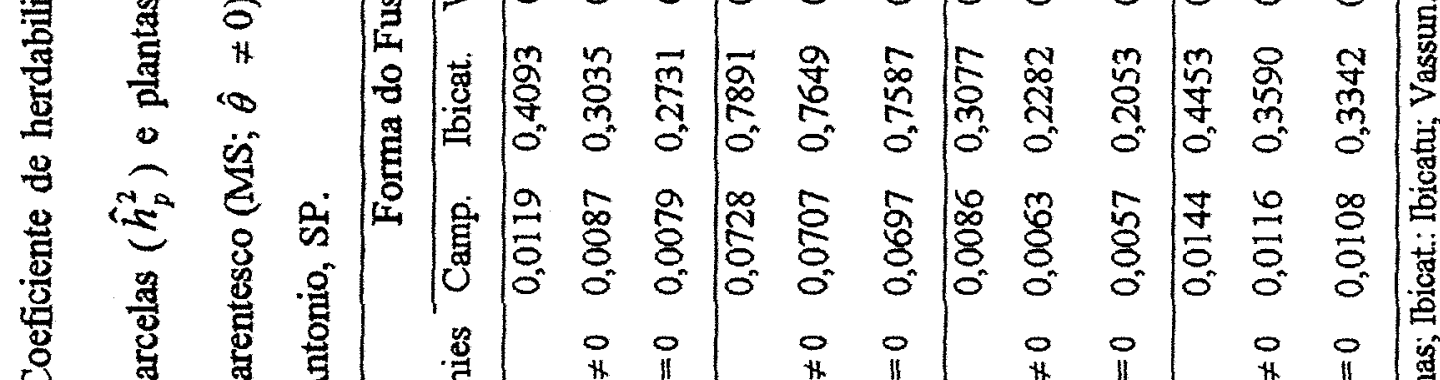

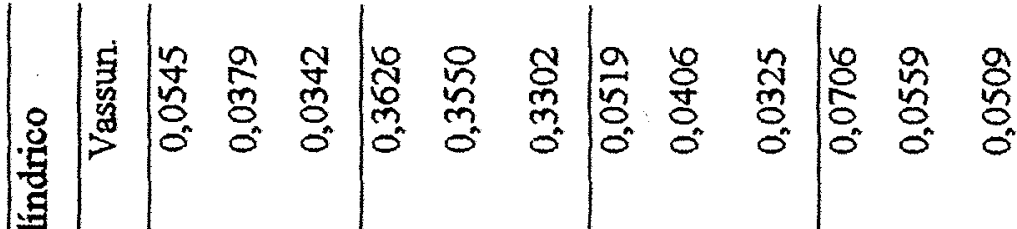

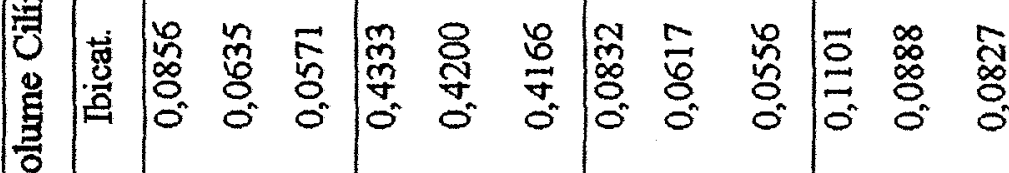

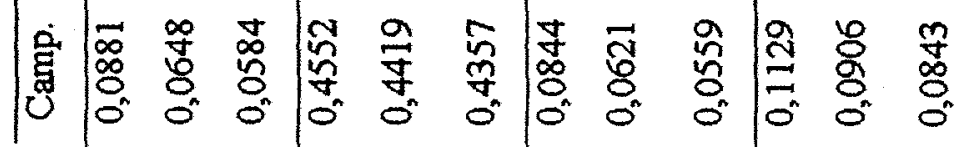

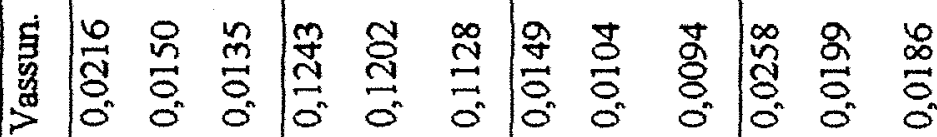

势

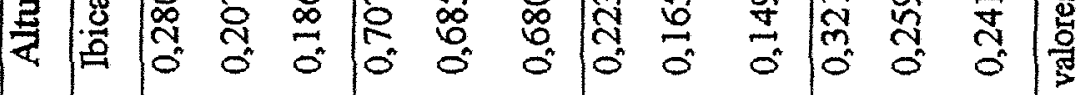

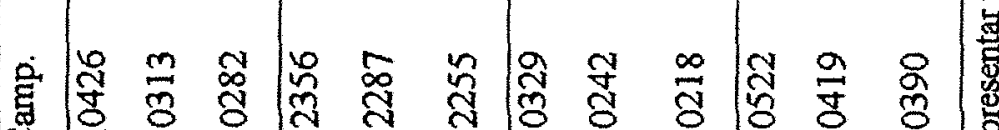

ن

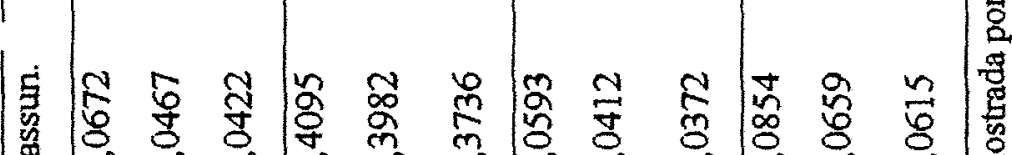

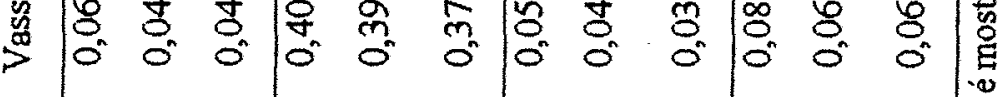

焉䓃

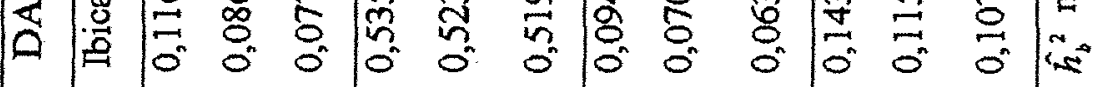

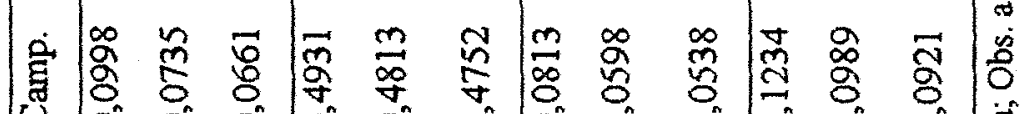

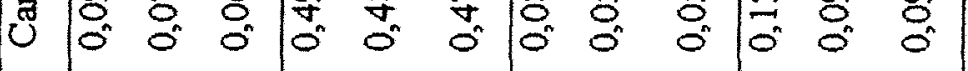

敨

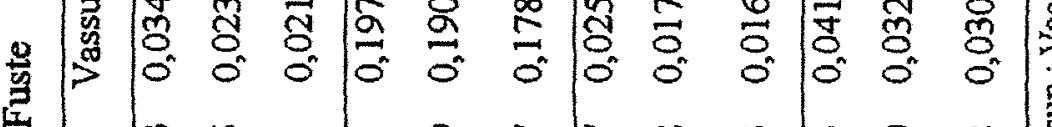

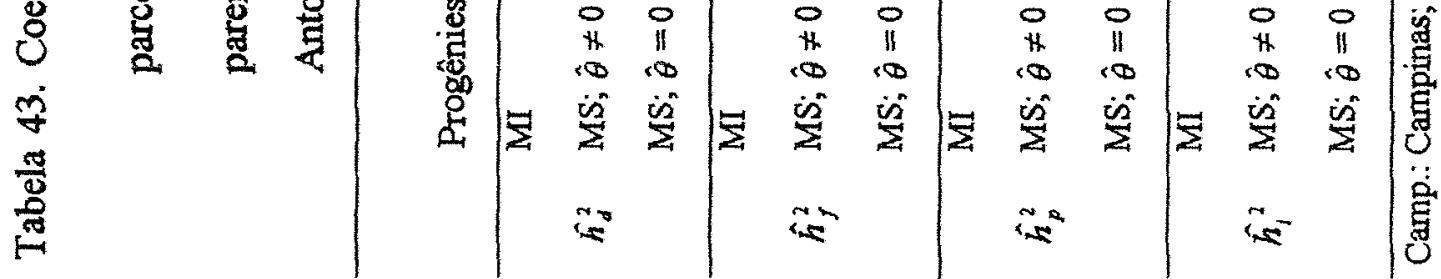


言量望

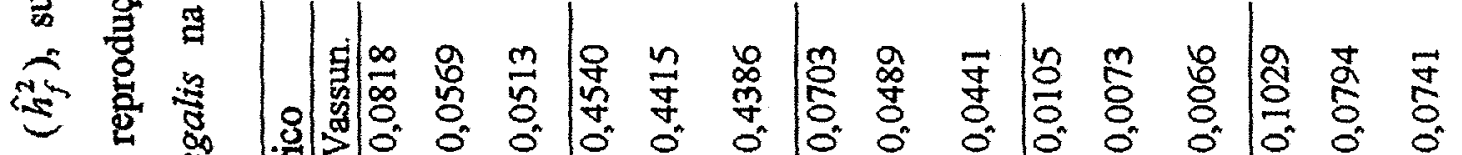

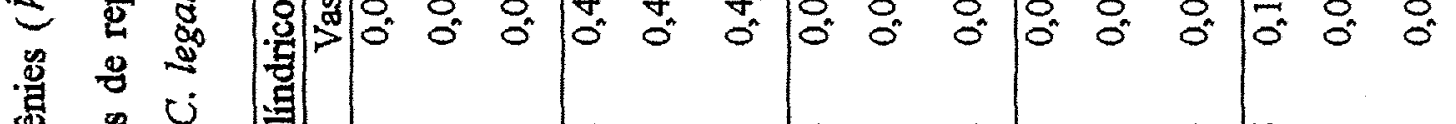

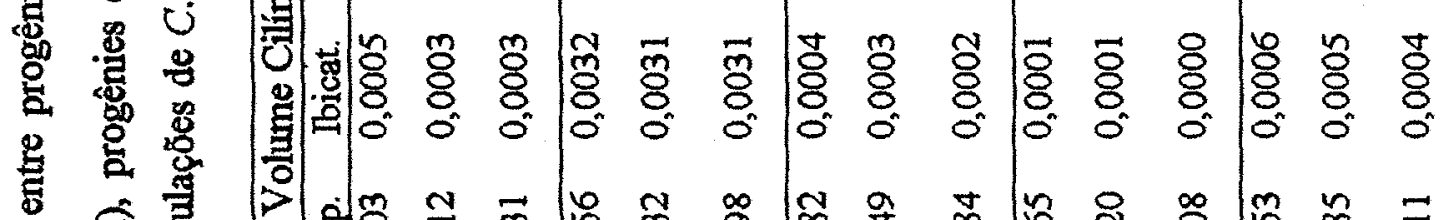

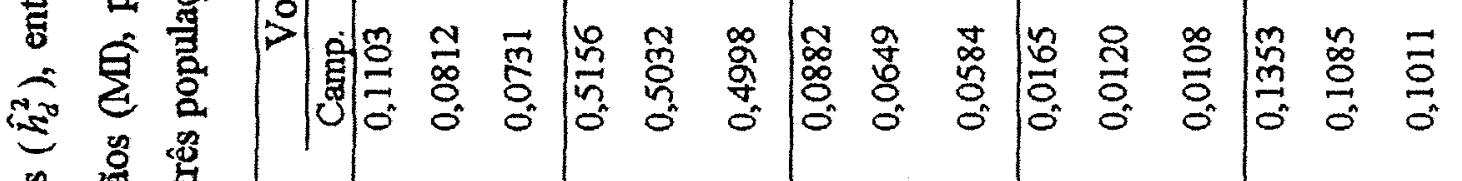

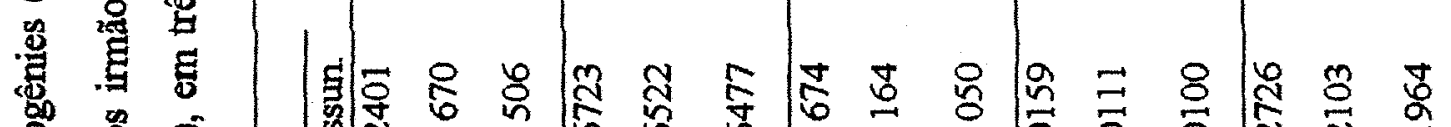

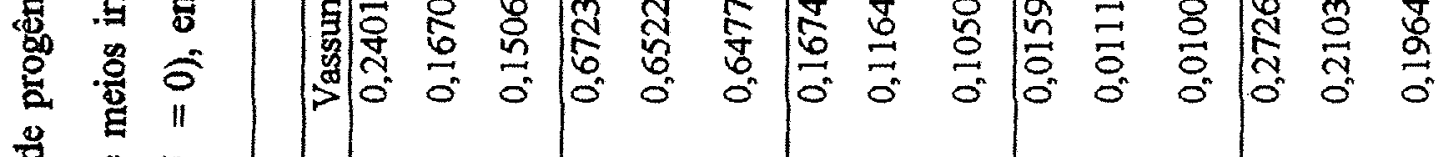

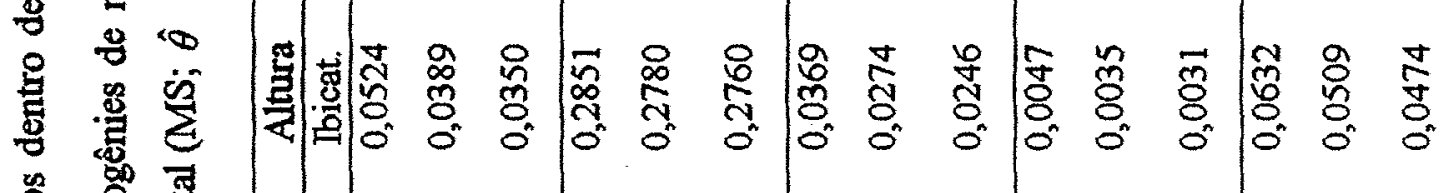

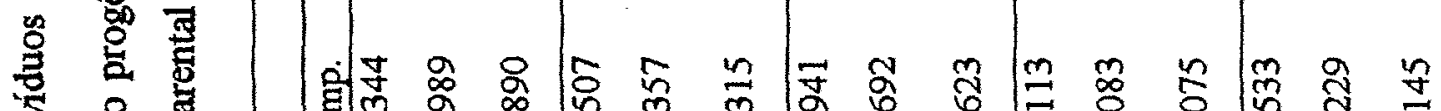

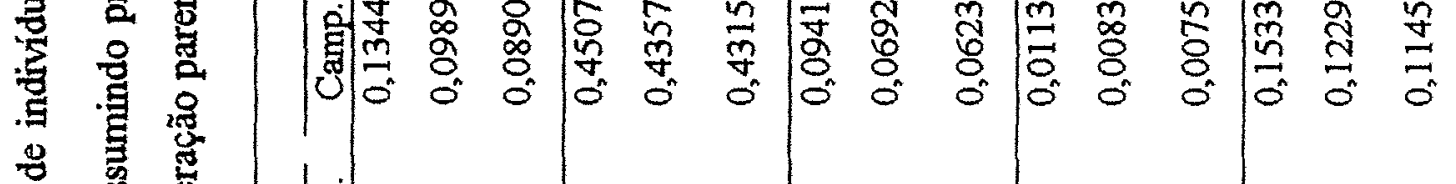

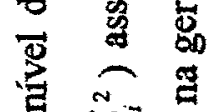

5

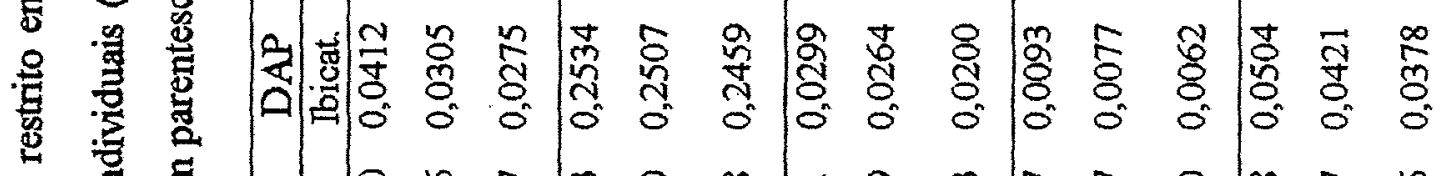

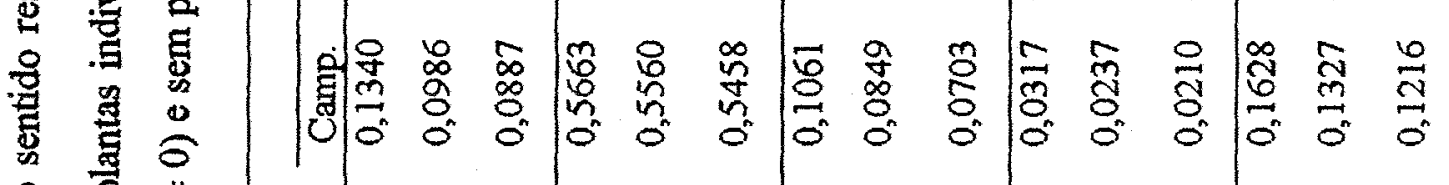
드 H

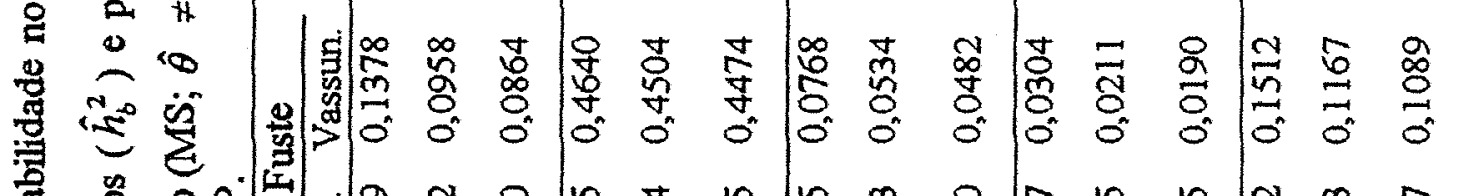
严 焉

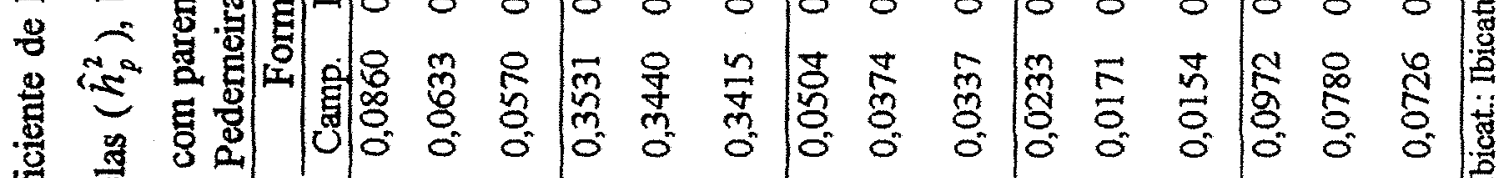

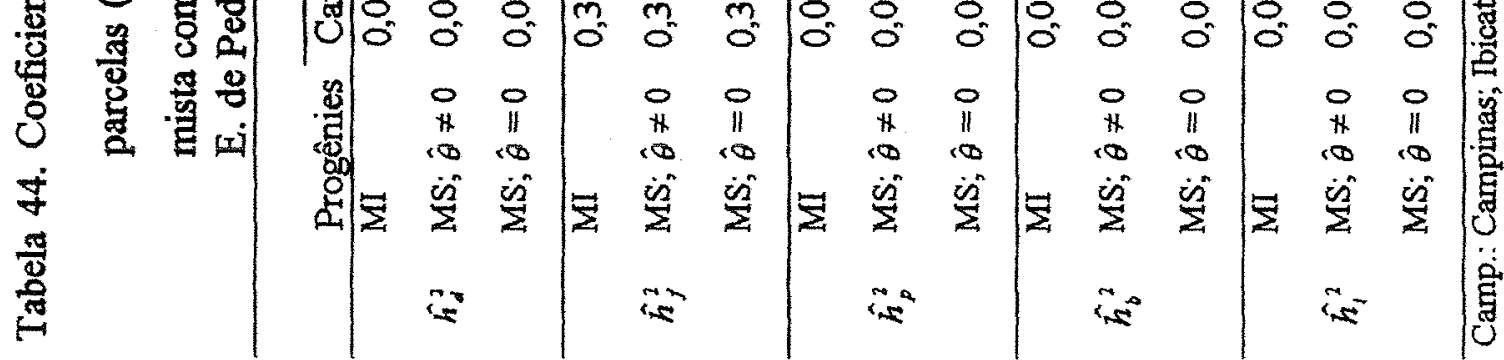


populações ocorreu porque estas apresentam características reprodutivas e estrutura intrapopulacional próprias, isto é, taxa de cruzamento, autofecundação, cruzamentos preferenciais, entre aparentados e diferentes proporções de meios irmãos, irmãos completos e indivíduos de autofecundação. Segundo, porque as diferentes herdabilidades ponderam diferentes coeficientes de parentesco nas suas estimativas, ou seja, coeficientes de parentesco entre e dentro de progênies, tendo assim, diferentes influências nas respectivas estimativas.

A herdabilidade dentro de progênies $\left(\hat{h}_{d}^{2}\right)$, em nível de sub-parcelas $\left(\hat{h}_{p}^{2}\right)$ e de blocos $\left(\hat{h}_{b}^{2}\right)$ apresentaram as maiores superestimativas considerando o parentesco (25 a $31 \%$ ) e ausência de parentesco $>33 \%$ ) (Anexos: Tabela 62). A herdabilidade em nível de plantas individuais $\left(\hat{h}_{1}^{2}\right)$ ficou superestimada em no mínimo $19 \%$, considerando o parentesco e em mais de $24 \%$ considerando ausência de parentesco. As menores superestimativas foram observadas para a herdabilidade entre progênies $\left(\hat{h}_{f}^{2}\right)$, com variação entre 2 e $3 \%$ considerando o parentesco e entre 3 e 10\% considerando ausência de parentesco. As maiores superestimativas ficaram com a população Vassununga. Em concordância, as estimativas da $\hat{\sigma}_{A}^{2}$, para todas as herdabilidades apresentaram maiores superestimativas para a situação de maior autofecundação (Pop. Vassununga). Estes resultados confirmam o trabalho de simulação de Squillace (1974) e Surles et al. (1990). Surles et al. (1990), por exemplo, observaram que a estimativa do coeficiente $\hat{h}_{t}^{2}$, considerando as progênies de Robinia pseudoacacia como de cruzamentos aleatórios (meios irmãos), sem parentesco e endogamia na geração parental, apresentava-se superestimada em $38 \%$ em relação à estimativa, considerando as progênies como de reprodução mista $(0,40$ e 0,29 , respectivamente). Quando os autores admitiram o parentesco de $6,5 \%$ entre os genitores, mas com ausência de endogamia na população parental, a superestimativa ficou na ordem de $10 \%(0,36)$.

Como é importante se obter medidas de heranças precisas para a predição de ganhos genéticos com a seleção, os resultados mostraram que as medidas do sistema de reprodução e de parentesco entre progenitores não podem ser negligenciadas, correndo-se o risco de se cometerem erros drásticos nas respectivas estimativas. Desta forma, o ideal é 
previamente realizar um estudo complementar do sistema reprodução e da estrutura genética das populações, de onde serão retiradas as progênies de polinização livre. Por isso, a partir deste ponto, a interpretação dos coeficientes de herdabilidade serão baseadas apenas nas estimativas feitas considerando-se os parâmetros do sistema misto de reprodução.

Em todas as situações, o coeficiente $\hat{h}_{f}^{2}$ apresentou os maiores valores, seguido pelos coeficientes $\hat{h}_{t}^{2}, \hat{h}_{d}^{2}, \hat{h}_{p}^{2}$ e $\hat{h}_{b}^{2}$. Comportamento semelhante foi observado por Resende \& Higa (1994b) para Eucalyptus grandis e Leonardecz (1998) para Pinus patula. Espera-se que os progressos genéticos sejam maiores de acordo com esta seqüência. A estimativa da $\hat{h}_{d}^{2}$ apresentou valores médios apenas para os caracteres FF e ALT na população Ibicatu em Luiz Antonio $(0,409$ e 0,280 , respectivamente) e baixos para as demais situações. Nas estimativas da $\hat{h}_{f}^{2}$ predominaram valores altos evidenciando um bom controle genético dos caracteres em nível de progênies, sendo possível a obtenção de progressos genéticos com a seleção das melhores progênies. As estimativas de $\hat{h}_{p}^{2}$ e $\hat{h}_{b}^{2}$ foram baixas na maioria das situações, inđicando poucas possibilidades de ganho com a seleção nestes níveis. Já em relação às estimativas de $\hat{h}_{i}^{2}$, estas foram baixas, desestimulando a utilização da seleção massal como estratégia de melhoramento.

Os coeficientes de herdabilidade estimados sugerem que, para qualquer método de seleção utilizado (índice de seleção multi-efeito e seleção entre e dentro de progênies), podem ser esperados maiores ganhos pela seleção em nível de progênies. Porém, progressos adicionais poderão ser obtidos incluindo-se os efeitos de indivíduos dentro de progênies, sub-parcelas e blocos para o caso de Pederneiras, onde este não foi nulo.

\subsubsection{Acurácias}

As acurácias associadas aos métodos de seleção foram estimadas admitindo-se que as progênies de polinização aberta foram geradas por cruzamentos aleatórios (MI), sendo sua relação de parentesco de meios irmãos e como de reprodução mista com parentesco 
(MS; $\hat{\theta} \neq 0$ ) e sem parentesco (MS; $\hat{\theta}=0$ ) na geração parental (Tabela 45). As comparações foram feitas com base nas considerações de Resende et al. (1995), os quais admitem valores de acurácia inferiores a 0,4 como baixos, entre 0,4 e 0,7 como medianos e superiores a 0,7 como altos.

Verifica-se que a acurácia está fortemente associada ao efeito de populações, sendo que, quando uma população apresenta maior acurácia seletiva em um caráter, este parâmetro é igualmente maior para todos os métodos de seleção, mostrando a consistência na superioridade de uma população sobre as demais. Por exemplo, em Luiz Antonio, para o caráter DAP, a população Ibicatu apresentou a maior acurácia em todos os métodos de seleção, sugerindo que, independente do método de seleção utilizado, o êxito do processo seletivo será sempre maior nesta, em relação às outras populações.

Na comparação entre os métodos de seleção, o índice multi-efeitos apresentou sempre as maiores acurácias, relativamente à seleção entre e dentro de progênies, indicando a possibilidade de obter-se maiores ganhos para qualquer caráter, população e local, a partir deste método.

A acurácia para o método de seleção índice multi-efeitos variou pouco com as diferentes estruturas de progênies. Já a acurácia para seleção entre progênies mostrou a tendência em aumentar quando se considera as progênies como misturas de diferentes graus de parentesco, com e sem parentesco entre os genitores. Por outro lado, a acurácia dentro das progênies tende a diminuir nesta situação. Isto acontece porque a correlação de parentesco entre progênies aumentou, em média, de $1 / 4(0,25)$ para aproximadamente $1 / 3$ $(0,33)$ e a correlação de parentesco dentro de progênies, diminuiu, em média, de $3 / 4(0,75)$ para $2 / 3(0,67)$, logo a variância aditiva na estimativa do valor genético entre progênies aumentou e dentro diminuiu, e as acurácias seguiram o padrão de redistribuição da $\hat{\sigma}_{A}^{2}$.

Quanto à magnitude das acurácias, não foram observados valores altos para nenhum método de seleção, apenas médios e baixos $(<0,7)$. O DAP apresentou valores médios para todas as populações em Luiz Antonio no índice de seleção multi-efeitos, sendo o caráter, local e método seletivo, mais indicado para a seleção. Isto mostra que a correlação entre o verdadeiro valor genético dos indivíduos candidatos à seleção e seus 
窟

要

管

定

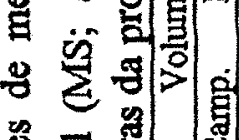

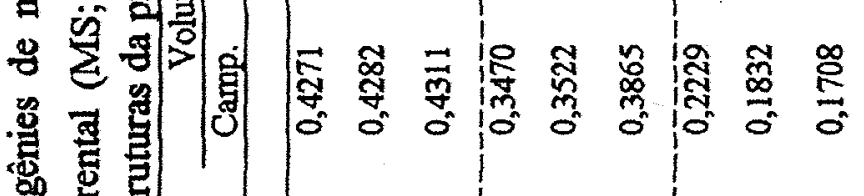

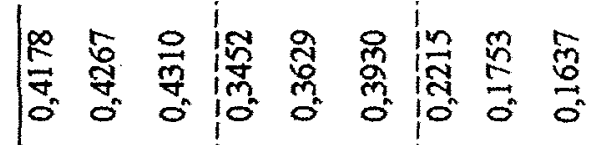

을

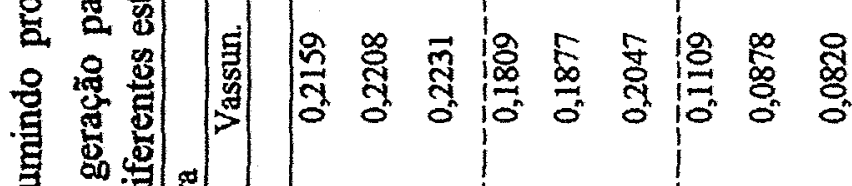

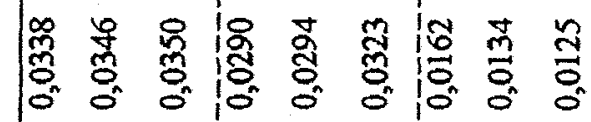

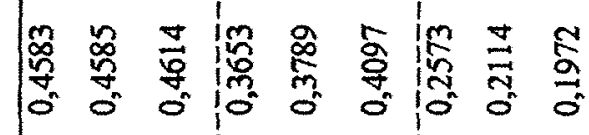

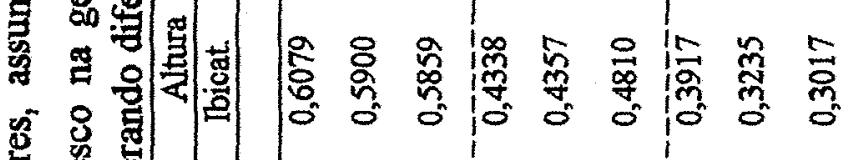

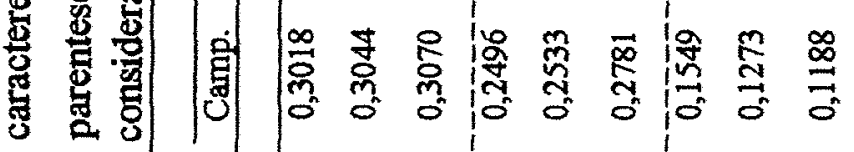

s.

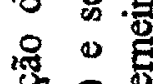

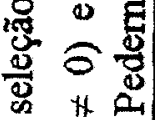

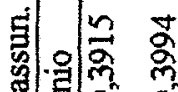

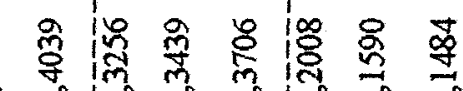

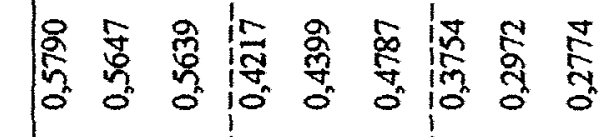

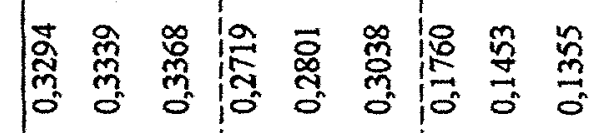

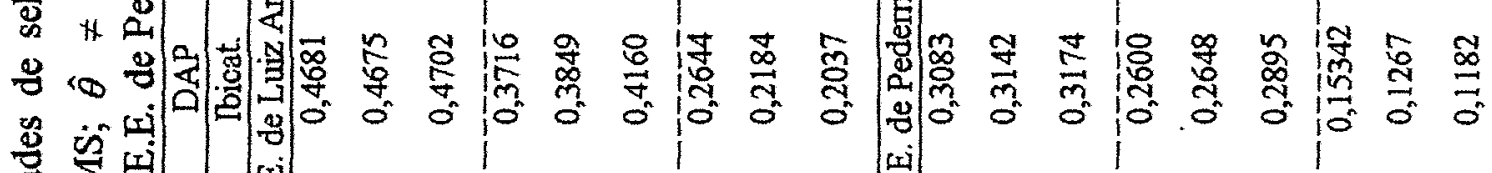

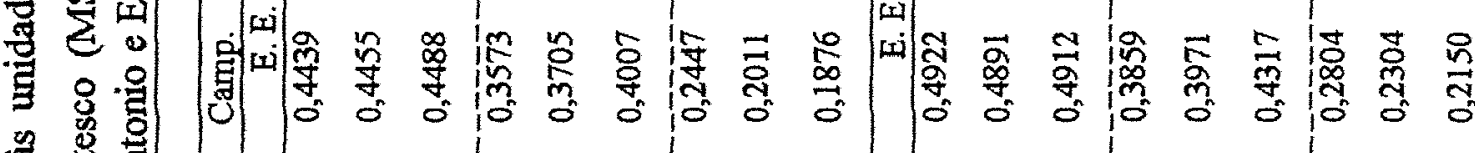
告产

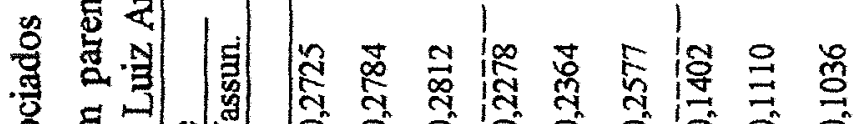

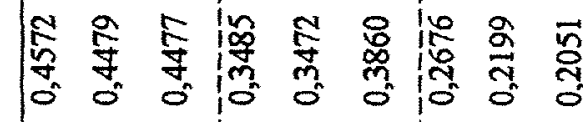

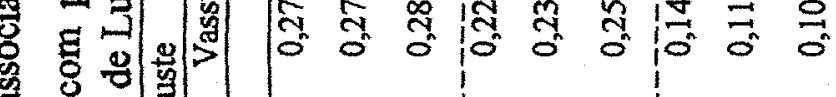

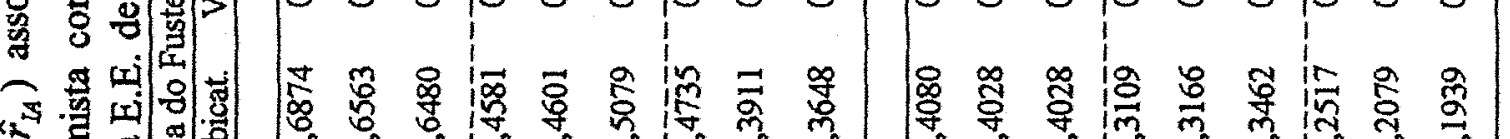

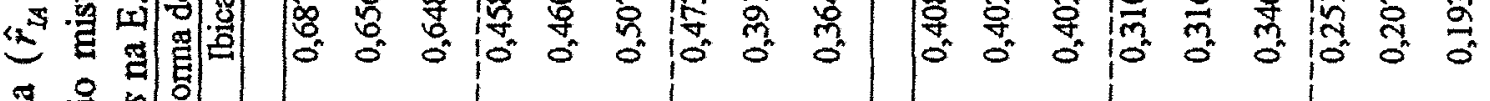

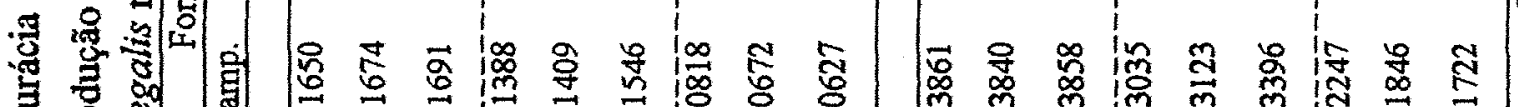

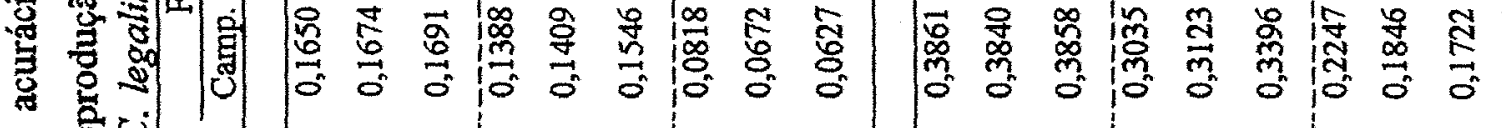

g

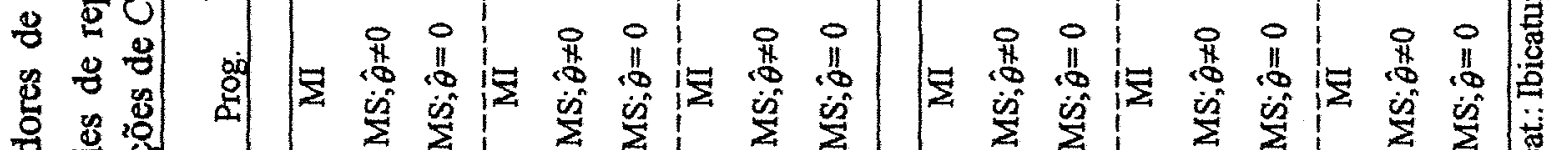

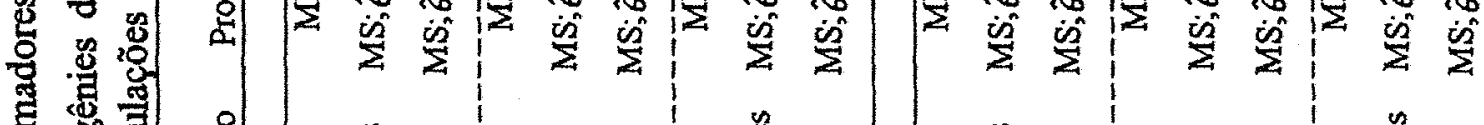

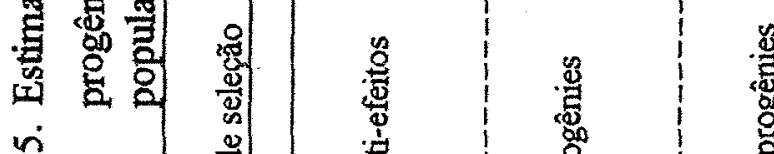

辛

올

总

प्ष

龸

竞

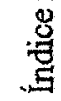

煦

8

量

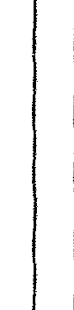

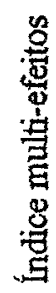

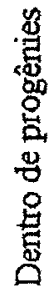

骂 
valores fenotípicos é razoável. A eficiência da seleção depende da herdabilidade dos caracteres sob seleção, número de progênies e indivíduos dentro de progênies, coeficiente de variação experimental e da intensidade de seleção aplicada pelo melhorista. Como aqui foram baixas as herdabilidades, o número de progênies $(\geq 16 \mathrm{e} \leq 22)$ e o número de indivíduos dentro de progênies ( $\leq 30$ por local) e a precisão experimental foi mediana (entre 10 e 20\%), altas acurácias não poderiam ser esperadas. Pode-se assim, prever baixos ganhos genéticos, com altas variâncias e amplos intervalos de confiança.

Resende et al. (1995) comparando 22 métodos de seleção de Pinus caribaea var. hondurensis, observaram, igualmente como aqui, acurácias variando de médias à baixas $(<0,7)$ para VC, sendo os maiores valores encontrados para o índice multi-efeitos em comparação à seleção entre progênies e dentro de progênies. Resultados similares também foram encontrados por Leonardecz (1998) para FF, DAP, ALT e VC em Pinus patula.

\subsubsection{Correlações Genéticas, Ambientais e Fenotípicas}

A maioria das correlações genéticas entre os caracteres foram positivas e altas nas populações em ambos locais de ensaio, evidenciando fortes efeitos pleiotrópicos ou que muitos genes que determinam a expressão de um caráter também determinam o outro (Tabela 46). As mais fortes correlações genéticas foram observadas entre os caracteres de crescimento DAP e ALT, DAP e VC e ALT e VC, indicando que a seleção em um destes caracteres leva a ganhos indiretos no outro. Considerando as correlações observadas e que - DAP é um caráter de fácil medição, com menores erros na obtenção dos dados em comparação aos caracteres como ALT e FF, este foi escolhido para a seleção.

$\mathrm{O}$ caráter FF apresentou algumas correlações genéticas negativas, como no caso do FF x DAP, na população Campinas em Pederneiras, e FF $x$ VC na população Vassununga em Luiz Antonio. Entretanto, ambas as correlações negativas foram baixas e não estatisticamente diferentes de zero. $\mathrm{O} \mathrm{FF}$, de modo geral, apresentou as mais fracas correlações com os caracteres de crescimento, porém, em muitas situações seus valores foram altos e significativos, indicando a possibilidade de ganhos indiretos a partir da seleção em um caráter. De modo geral, as correlações genéticas não mostraram restrições na adoção de apenas um caráter para a seleção. 
As correlações ambientais foram altas e significativas entre todos os caracteres em Luiz Antonio e entre os caracteres de crescimento (DAP, ALT e VC) em Pederneiras, mostrando que as características ambientais influenciam simultaneamente a resposta dos caracteres, ou melhores características ambientais beneficiam simultaneamente 0 desempenho de todas os caracteres.

As correlações fenotípicas foram semelhante as correlações ambientais, confirmando o que a análise da herança dos caracteres já havia mostrado, a partir dos coeficientes de herdabilidade, que os caracteres são muito influenciados pelos efeitos ambientais.

As baixas correlações genéticas, ambientais e fenotípicas, observadas entre o caráter FF com os caracteres de crescimento em Pederneiras, possivelmente estão associadas aos erros experimentais, como a baixa precisão na mensuração das formas das árvores.

Como as correlações entre os caracteres de crescimento foram positivas, altas e significativas nos dois locais, optou-se pelo caráter DAP como objetivo de seleção, devido às considerações anteriormente apresentadas e, porque a madeira da C. legalis é indicada principalmente para serrarias (ver revisão). Assim, o principal objetivo do melhoramento

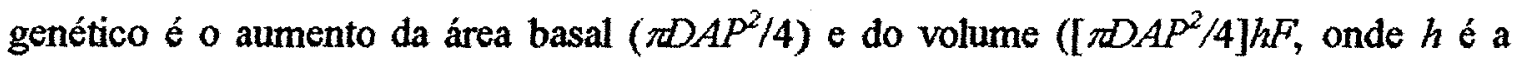
altura e o $F$ é o fator de forma). Para a escolha deste caráter também foram considerados os coeficientes de herdabilidade, a acurácia seletiva e o coeficiente de variação experimental, parâmetros que medem o controle genético dos caracteres e a precisão experimental, $\log o$ o potencial e a eficiência seletiva do caráter. Foram então estimados os ganhos genéticos, nos dois locais de ensaio, apenas para o DAP. 


\subsubsection{Ganhos Preditos na Seleção}

As diferenças nas estimativas de ganhos em Luiz Antonio e Pederneiras, considerando as progênies como de cruzamentos aleatórios e como de cruzamentos mistos com e sem parentesco na população parental, apresentaram valores superestimados variando de 2 a 37,5\%, entre os diversos métodos de seleção (Tabelas 47 e 48). Os resultados evidenciaram em todos os métodos de seleção a tendência de aumento nas superestimativas com o aumento na taxa de autofecundação nas populações. Por exemplo, comparando a população de maior taxa de autofecundação (Vassununga, 10\%) com as de menores taxas (Campinas e Ibicatu), observa-se que a superestimativa para o índice multiefeitos foi de no mínimo $16,9 \%$ quando se considerou ausência de parentesco nas populações, para o caso da populações Vassununga em Pedemeiras. As demais estimativas do índice multi-efeitos apresentaram superestimativas na ordem de $19 \%$. Já, quando se considerou as progênies como de reprodução mista, com parentesco na população parental as superestimativas ficaram entre 14 e 16\%.

A seleção entre progênies apresentou as menores superestimativas (máximo 4\%), sendo que na presença de parentesco entre genitores os valores foram sensivelmente inferiores. Por sua vez, a seleção dentro de progênies apresentou as maiores superestimativas, com valores acima de $33 \%$ quando se considera a ausência de parentesco e entre 25 e $30 \%$ quando se considera a presença de parentesco. A seleção seqüencial entre e dentro de progênies apresentou superestimativas na ordem de $20 \%$ na ausência de parentesco e de $16 \%$ na presença de parentesco na geração parental, portanto, similares às apresentadas pelo índice multi-efeitos. Surles et al. (1990) obtiveram superestimativas de ganhos na ordem de $\mathbf{3 8 \%}$, quando as progênies de polinização aberta eram avaliadas como meios irmãos. Isto mostra que, quando se objetiva medidas acuradas dos ganhos na seleção a suposição de cruzamentos aleatórios não pode ser admitida previamente, sem um estudo detalhado do sistema de reprodução. 


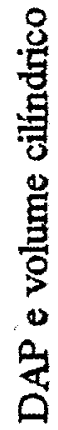

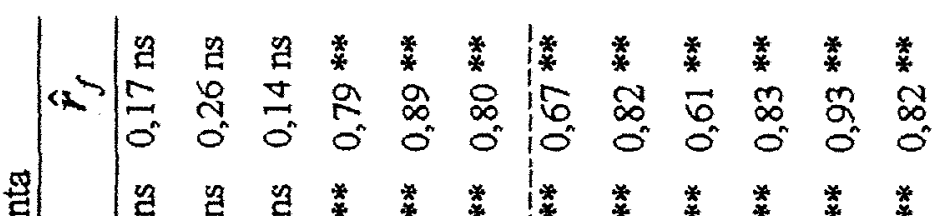
苞

存

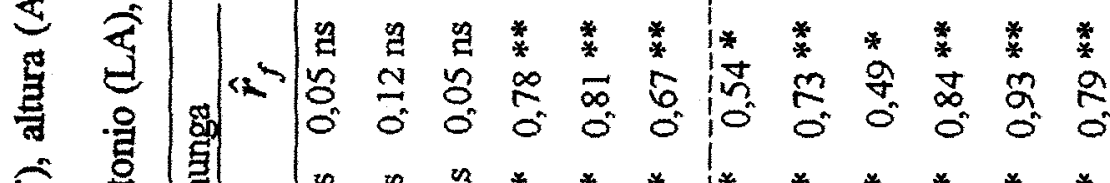

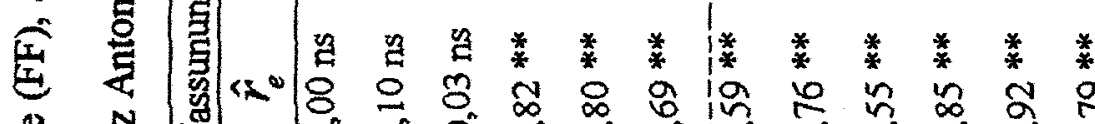

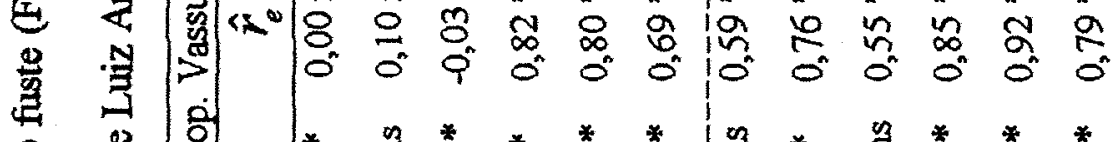

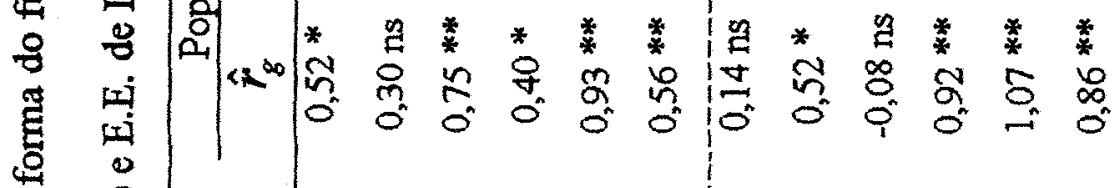

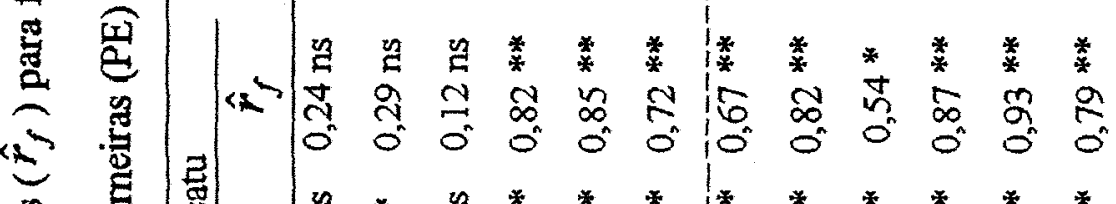

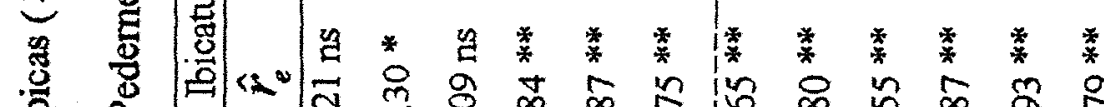

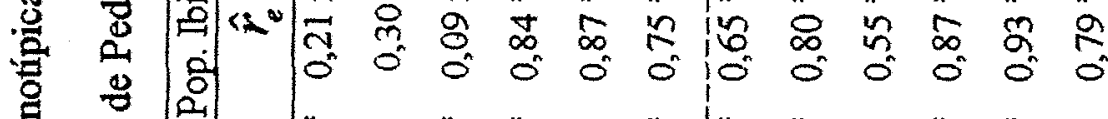

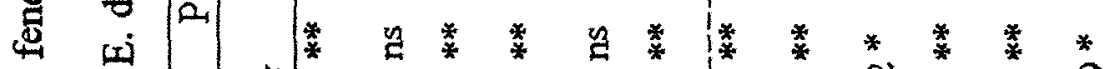

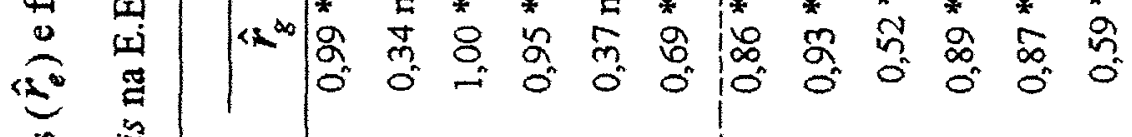
然

卷

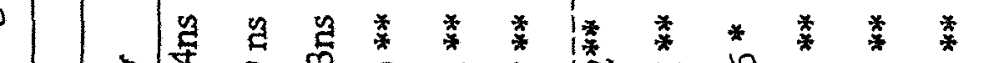

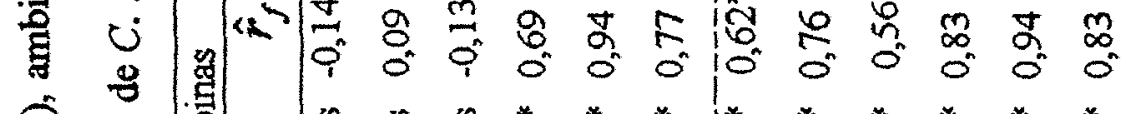

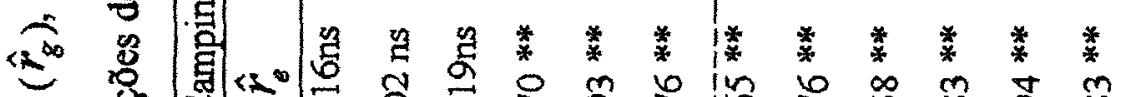

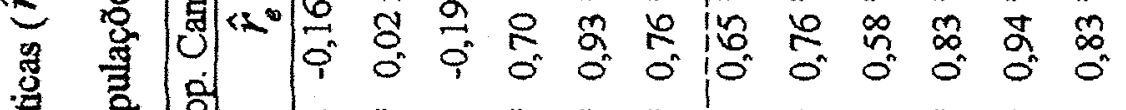

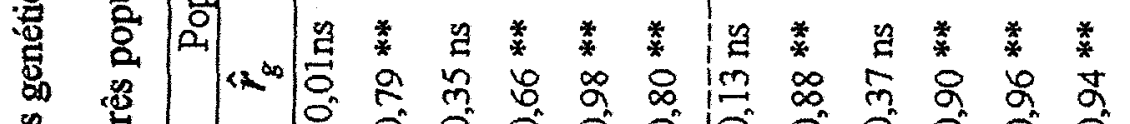

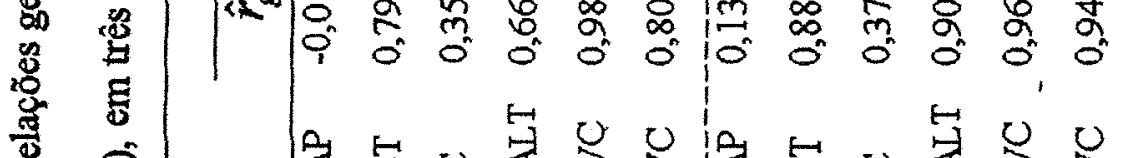
8 e 安

蛋

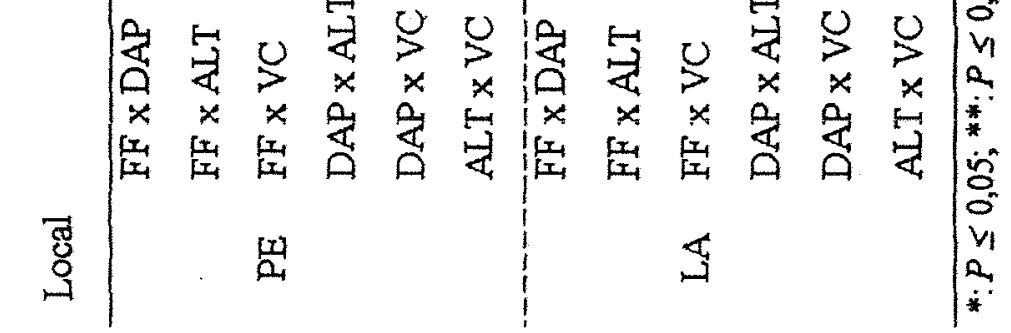


Tabela 47. Progresso genético esperado pela seleção (Gs) para o caráter DAP, em diferentes estruturas de progênies, para diferentes unidades de seleção, em três populações de $C$. legalis, em dois locais de ensaio e tamanho efetivo $\left(\hat{N}_{e}\right)$ da população selecionada.

\begin{tabular}{|c|c|c|c|c|c|c|c|}
\hline \multirow[b]{2}{*}{ Progênies } & \multirow[b]{2}{*}{ Unid. Seleção } & \multicolumn{2}{|c|}{ Pop. Campinas } & \multicolumn{2}{|l|}{ Pop. Ibicatu } & \multicolumn{2}{|c|}{ Pop. Vassumunga } \\
\hline & & Gs (\%) & $\hat{N}_{s}$ & Gs (\%) & $\hat{N}_{a}$ & Gs (\%) & $\hat{N}_{g}$ \\
\hline \multicolumn{8}{|c|}{ Estação Experimental de Luiz Antonio } \\
\hline \multirow{4}{*}{ MI } & Multi-efeito & $8,2(5,1$ a 11,4$)$ & $\ldots$ & $9,4(5,9$ a 12,9$)$ & - & $7,7(4,7$ a 10,6$)$ & -..- \\
\hline & Sel. Entre & $3,1(0,6$ a 5,7$)$ & & $3,1(0,3$ a 6,0$)$ & & $2,8(0,4$ a 5,3$)$ & \\
\hline & Sel. Dentro & $4,4(2,7$ a 6,2$)$ & & $5,5(3,5$ a 7,5$)$ & & $4,0(2,4$ a 5,5$)$ & \\
\hline & Entre e dentro & $7,6(3,4$ a 11,9$)$ & --- & $8,5(3,7$ a 13,3$)$ & -... & $6,8(2,8$ a 10,8$)$ & $\ldots$ \\
\hline \multirow{4}{*}{$\mathrm{MS} ; \hat{\theta} \neq 0$} & Multi-efeito & $7,1(3,9$ a 10,1$)$ & $\ldots$ & $7,8(4,3$ a 11,4$)$ & -..- & $6,4(3,4$ a 9,5$)$ & $-\cdots$ \\
\hline & Sel. Entre & $3,0(0,5$ a 5,7$)$ & & $3,0(0,1$ a 6,0$)$ & & $2,7(0,2$ a 5,4$)$ & \\
\hline & Sel. Dentro & $3,3(1,9$ a 4,7$)$ & & $4,1(2,4$ a 5,6$)$ & & $2,7(1,5 a 4,0)$ & \\
\hline & Entre e dentro & $6,4(2,3$ a 10,4$)$ & $\ldots$ & $7,1(2,5$ a 11,6$)$ & $\ldots$ & $5,5(1,7$ a 9,3$)$ & $\ldots$ \\
\hline \multirow{4}{*}{$\mathrm{MS} ; \hat{\theta}=0$} & Multi-efeito & $6,6(3,5$ a 9,8$)$ & 30,6 & $7,4(3,9$ a 10,9$)$ & 31,7 & $6,2(3,1$ a 9,2$)$ & 28,7 \\
\hline & Sel. Entre & $3,1(0,2$ a 5,9$)$ & & $3,0(-0,1$ a 6,2$)$ & & $2,8(-0,1$ a 5,6$)$ & \\
\hline & Sel. Dentro & $2,9(1,6$ a 4,3$)$ & & $3,7(2,1$ a 5,2$)$ & & $2,5(1,4 \mathrm{a}, 3,6)$ & \\
\hline & Entre e dentro & $6,0(1,8 \mathrm{a} 10,2)$ & .... & $6,2(2,0$ a 11,3$)$ & .... & $5,2(1,3$ a 9,2$)$ & $\ldots$ \\
\hline \multicolumn{8}{|c|}{ Estação Experimental de Pedemeiras } \\
\hline \multirow{4}{*}{ MI } & Multi-efeito & $9,5(6,9 \mathrm{a} 12,1)$ & -..- & $3,0(1,1$ a 4,9$)$ & .... & $7,9(5,3$ a 10,4$)$ & $\cdots$ \\
\hline & Sel. Entre & $3,2(0,6$ a 5,9$)$ & & $1,2(-0,8$ a 3,1$)$ & & $3,8(1,0$ a 6,5$)$ & \\
\hline & Sel. Dentro & $4,5(1,6$ a 7,4$)$ & & $1,4(-0,6$ a 3,4$)$ & & $2,8(0,2$ a 5,4$)$ & \\
\hline & Entre e dentro & $8,3(6,2$ a 10,4$)$ & -... & $2,7(0,9$ a 4,4$)$ & .... & $7,0(4,7$ a 9,2$)$ & $\ldots$ \\
\hline \multirow{4}{*}{$\mathrm{MS} ; \hat{\theta} \neq 0$} & Multi-efeito & $8,1(5,8$ a 10,4$)$ & - & $2,5(0,8 \mathrm{a} 4,3)$ & - & $6,8(4,5$ a 9,0$)$ & - \\
\hline & Sel. Entre & $3,1(0,8$ a 5,5$)$ & & $1,1(-0,7$ a 2,9$)$ & & $3,7(1,3$ a 6,1$)$ & \\
\hline & Sel. Dentro & $3,3(0,6$ a 6,0$)$ & & $1,1(-0,8$ a 2,9$)$ & & $2,0(-0,4$ a 4,3$)$ & \\
\hline & Entre e dentro & $6,9(4,9$ a 8,9$)$ & $\ldots$ & $2,2(0,6$ a 3,9$)$ & $\ldots$ & $5,9(3,9$ a 7,9$)$ & $\ldots$ \\
\hline \multirow{4}{*}{$\mathrm{MS} ; \hat{\theta}=0$} & Multi-efeito & $7,7(5,5 \mathrm{a} 10,0)$ & 26,4 & $2,4(0,8$ a 4,1$)$ & 34,2 & $6,5(4,4$ a 8,7$)$ & 24,7 \\
\hline & Sel. Entre & $3,1(0,9$ a 5,3$)$ & & $1,1(-0,6$ a 2,8$)$ & & $3,7(1,4$ a 5,9$)$ & \\
\hline & Sel. Dentro & $2,9(0,4$ a 5,6$)$ & & $1,0(-0,8 \mathrm{a} 2,7)$ & & $1,8(-0,5$ a 4,0$)$ & \\
\hline & Entre e dentro & $6,5(4,7$ a 8,4$)$ & -..- & $2,1(0,6$ a 3,7$)$ & $\ldots$ & $5,6(3,7$ a 7,6$)$ & --_ \\
\hline
\end{tabular}

(): Intervalo de confiança do erro da estimativa do ganho, à $95 \%$ de probabilidade.

LUIZ ANTONIO - Pop. Campinas: Seleção índice multi-efeito (IME) e entre e dentro de progênies (ED): Seleção de 44 individuos em 11 progênies); Pop. Ibicatu: Seleção IME e ED: Seleção de 32 individuos em 8 progênies); Pop. Vassununga: Seleção IME e ED: Seleção de 36 individuos em 9 progênies);

PEDERNEIRAS - Pop. Campinas: Seleção IME e ED: Seleção de 40 individuos em 10 progênies); Pop. Ibicatu: Seleção IME e ED: Seleção de 36 individuos em 9 progênies); Pop. Vassununga: Seleção IME e ED: Seleção de 40 indivíduos em 10 progênies); Obs: Na seleção ED foram selecionados 4 indivíduos por progênie, em diferentes blocos e na seleção índice multi-efeitos de 1 a 6 individuos, também em diferentes blocos (ver Tabela 61 em anexo); MI: Progênies de meios irmãos; MS; $\hat{\theta}=0$ : Progênies de sistema misto de reprodução sem parentesco na geração parental; MS; $\hat{\theta} \neq 0$ : Progênies de sistema misto de reprodução com parentesco na geração parental. 
Tabela 48. Percetual (\%) das diferenças nos progressos genéticos esperados admitindo-se progênies de meios irmãos, em relação às progênies de reprodução mista sem endogamia (MS; $\hat{\theta}=0)$ e com endogamia $(M S ; \hat{\theta} \neq 0)$ na geração parental, para as diferentes unidades de seleção em populações de $C$. legalis.

\begin{tabular}{|c|c|c|c|c|c|c|c|}
\hline & & \multicolumn{3}{|c|}{$\mathrm{MS} ; \hat{\theta}=0$} & \multicolumn{3}{|c|}{$\mathrm{MS} ; \hat{\theta} \neq 0$} \\
\hline & & Camp. & Ibicatu & Vassun. & Camp. & Ibicatu & Vassun. \\
\hline & Indice multi-efeito & 19,1 & 21,2 & 19,7 & 15,0 & 16,5 & 16,1 \\
\hline \multirow[t]{4}{*}{ LA } & Entre progênies & 3,1 & 3,0 & 3,4 & 2,4 & 2,4 & 2,8 \\
\hline & Dentro de progênies & 33,8 & 33,3 & 37,2 & 26,4 & 25,8 & 30,5 \\
\hline & Entre e dentro & 21,1 & 22,2 & 23,0 & 16,4 & 17,2 & 18,9 \\
\hline & Indice multi-efeito & 19,0 & 19,0 & 16,9 & 14,8 & 14,8 & 13,8 \\
\hline \multirow[t]{3}{*}{$\mathrm{PE}$} & Entre progênies & 3,3 & 3,5 & 3,6 & 2,6 & 2,8 & 2,9 \\
\hline & Dentro de progênies & 33,8 & 33,3 & 37,3 & 26,5 & 26,0 & 30,4 \\
\hline & Entre e dentro & 21,1 & 20,5 & 19,1 & 16,5 & 16,0 & 15,6 \\
\hline
\end{tabular}

LA: E. E. de Luiz Antonio; PE: E. E. de Pederneiras.

O sistema misto de reprodução em essências florestais parece ser comum tanto em Angiospermas como Gimnospermas. Vários estudos de espécies arbóreas tropicais têm revelado o sistema misto como forma predominante de reprodução (O'Malley \& Bawa, 1987; Moran et al., 1989; Murawski et al., 1990; Murawski \& Hamrick, 1991; Murawski \& Bawa, 1994; Moraes, 1993; Murawski et al., 1994; Changtragoon \& Finkeldey, 1995; Gibson et al., 1996; Liengsiri et al., 1998; Moraes, 1997; Sebbenn et. al., 1998; Seoane, et al., 2000; Sebbenn et al., 2000; Mori, 2000, entre outros). Da mesma forma, a literatura mostra que o sistema misto não é exclusivo das Angiospermas, existindo muitas Gimnospermas com tal forma de reprodução (Moran \& Brown, 1980; Mitton et al., 1981; Shaw \& Allard, 1982; El-Kassaby et al., 1981; Boyle \& Morgenstern, 1986; Perry \& Dancik, 1986).

Outro ponto importante é o fato de que mesmo que as espécie apresentem autoincompatibilidade ou outros mecanismos que favoreçam taxas de cruzamento próximas a 1,0 (dioicia), dificilmente será possível admitir que os cruzamentos ocorram de forma aleatória nas populações naturais ou nos pomares de sementes, devido aos seguintes fatores: a) assincronismo no florescimento; ii), dispersão restrita de pólen; iii) diferenças na maturidade reprodutiva (É provável que árvores maiores liberem mais pólen do que as menores). Devido a isso, dificilmente uma progênie coletada de uma árvore de polinização 
aberta será constituída exclusivamente de meios irmãos, sendo muito provável também, a presença de um grande número de irmãos completos. Isto implica que as estimativas de parâmetros genéticos obtidas a partir de progênies de polinização aberta dificilmente são precisas, mesmo em ensaios que incluam grande número de progêmies e plantas dentro de progênies. Entretanto, estes erros serão reduzidos caso existam parentescos entre os genitores, como foi demostrado por Squillace (1974) e Surles et al. (1990), e aqui neste trabalho.

As considerações apresentadas sobre o sistema misto de reprodução não são restritivas quanto ao uso de progênies de polinização aberta, pelo contrário, este tipo de material apresenta muitas vantagens em programas de melhoramento e conservação genética, como rapidez, baixo custo de obtenção e maior tamanho efetivo populacional, comparativamente à progênies de irmãos completos ou de autofecundação. Elas somente mostram que, em situações que se almejam medidas acuradas de heranças e ganhos, é necessário que algumas medidas do sistema de reprodução sejam tomadas, o que pode ser facilmente realizado, utilizando-se marcadores genéticos codominantes (isoenzimas; microssatélites, RFLP etc).

Na seleção entre e dentro de progênies (Tabela 47), as estimativas de ganhos a partir das correções da variância genética aditiva para os parâmetros do sistema de reprodução, apesar de reduzirem ambos os níveis (entre e dentro), foram maiores entre do que dentro de progênies, devido a uma proporção maior da variância genética aditiva dentro ser transferida entre as progênies. Desta forma, a covariância e o coeficiente de parentesco dentro das progênies aumentam, conseqüentemente aumentando a variância genética entre, pela redução no parentesco entre progênies. Por exemplo, em progênies de meios irmãos, tem-se $1 / 4$ de $\hat{\sigma}_{A}^{2}$ entre e $3 / 4$ de $\hat{\sigma}_{A}^{2}$ dentro de progênies e com as correções para o sistema de reprodução a $\hat{\sigma}_{A}^{2}$ entre progênies aumenta para aproximadamente $1 / 3 \mathrm{e}$ a $\hat{\sigma}_{A}^{2}$ dentro de progênies diminui para $2 / 3$. Desta forma, com maior variância genética herdável (aditiva) entre progênies de reprodução mista, comparativamente às progênies de meios irmãos (alógamas), maiores tornam-se os ganhos obtidos na seleção entre.

Em função das considerações e resultados apresentados, as próximas interpretações serão focadas apenas nos resultados obtidos para a análise, considerando as 
progênies de $C$. legalis como de reprodução mista com parentesco entre os genitores (MS; $\hat{\theta} \neq 0)$.

Os ganhos esperados em Luiz Antonio foram, no geral, superiores aos de Pederneiras para todas as populações e métodos de seleção, mesmo no caso da população Vassununga, que apresentava um número menor de progênies neste ensaio. Nota-se também na Tabela 63 (anexo), uma forte associação nas progênies selecionadas entre os locais ou muitas das progênies selecionadas em um local também foram selecionadas em outro. Isto indica que o material selecionado é razoavelmente estável.

Em Luiz Antonio, os ganhos foram maiores nas populações Campinas e Ibicatu para todos os métodos de seleção, atingindo o patamar de até $10 \%$. Na população Vassununga estes ganhos ficaram em torno de 6\%. Contudo, avaliando o intervalo de confiança à $95 \%$ das estimativas de ganhos, observa-se que não existem diferenças significativas entre as populações. Em Pederneiras os ganhos foram maiores para a população Campinas, seguida de Vassununga e Ibicatu, para os dois métodos de seleção. Os ganhos na População Campinas e Vassununga foram similares aos encontrados em Luiz Antonio (8 e 6\%, respectivamente), sugerindo que estas populações apresentam maior estabilidade do que as populações Ibicatu, assim poderiam ser recomendadas para $o$ plantio em ambos locais. Os ganhos na população Ibicatu em Pederneiras foram baixos, em torno de $2 \%$, mostrando poucas possibilidade de progressos com a seleção dentro desta população neste local de ensaio. No entanto, igualmente como em Luiz Antonio, os intervalos de confiança mostraram que estas estimativas não são estatisticamente diferentes entre populações.

Comparando os ganhos preditos para os métodos de seleção, verifica-se que os progressos foram maiores para o índice multi-efeitos, evidenciando que a seleção baseada em todos os efeitos do modelo da análise de variância trouxe acréscimos na precisão da seleção. Resende et al. (1995) e Leonardecz (1998) também encontraram maiores ganhos na utilização do índice multi-efeitos na seleção de Pinus caribaea var. hondurensis e Pinus patula, respectivamente. Segundo Resende et al. (1995), na escolha do método de seleção, devem ser considerados simultaneamente a acurácia seletiva e o intervalo de confiança do ganho, atentando os autores para o fato de que maiores acurácias propiciam 
intervalos mais estreitos, sendo por isso, necessário comparar-se exclusivamente os intervalos inferiores, onde os métodos de seleção, com maiores limites inferiores dos intervalos de confiança (IC), podem ser julgados como melhores, por permitirem maior segurança na seleção. No presente caso, o índice de seleção multi-efeito apresentou intervalos menos amplos que a seleção entre e dentro de progênies, portanto, é o método mais indicado para a seleção. Assim, deve-se tomar as valores de 3,9, 4,3 e 3,4\%, em Luiz Antonio e 5,8, 0,8 e 4,5\% em Pederneiras, nas populações Campinas, Ibicatu e Vassununga, respectivamente, como os mais plausíveis, e não os valores médios de ganhos. As magnitudes dos ganhos esperados, mesmo considerando a redução causada pelas correções dos parâmetros do sistema de reprodução, podem ser consideradas como boas, dado que a base genética entre e dentro das progênies nas populações é restrita, para o máximo de 22 progênies (Vassununga - Pederneiras) e 30 indivíduos dentro das progênies.

Como este trabalho engloba dois objetivos distintos, mas complementares, a conservação ex situ e o melhoramento genético, sugere-se manter o ensaio de Pederneiras para a conservação ex situ, por conter um número maior de progênies (55), possibilitando maior base genética e o ensaio de Luiz Antonio para iniciar um programa de melhoramento visando o aumento da produtividade de caracteres de crescimento (DAP, ALT e VC). Nesta proposta também pesa o fato de que o ensaio de Luiz Antonio apresentou os maiores ganhos.

A seleção dentro e recombinação entre e dentro das populações, em Luiz Antonio, dará origem a um "pomar de sementes por mudas", do tipo multipopulações. Esta estratégia levará ao aumento da base genética das populaçōes originais, capitalizando ganhos iniciais para os caracteres de valor econômico, em uma nova população base, melhorada, composta de 30 possiveis diferentes progênies e tendo um tamanho efetivo inicial de 91 indivíduos $(30,6+31,7+28,7$, pop. Campinas, Ibicatu e Vassununga, respectivamente). $O$ tamanho efetivo a ser obtido é de magnitude superior ao proposto corriqueiramente em trabalhos de melhoramento florestal (50 - Namkoong, 1979), permitindo que genes com freqüência em tomo de $5 \%$ sejam retidos na população selecionada. 
A nova população de recombinação será formada com base no desempenho hierárquico das populações originais ou contribuirá em maior proporção para esta; as populações, progênies e indivíduos dentro de progênies de melhor desempenho para o caráter DAP. A contribuição de cada nível hierárquico pode ser observada na Tabelas 61 (anexo), onde a população Campinas, de melhor desempenho, contribuirá com 10 progênies e 44 indivíduos, a Ibicatu com 10 progênies e 32 indivíduos e a Vassununga com 9 progênies e 36 individuos. Assim, fica claro que as freqūências alélicas da nova população serão dominadas, principalmente pelas freqüências da populą̧ão de melhor desempenho, Campinas.

O referido pomar pode, além de servir como base para um programa de melhoramento, suprir a demanda de sementes de $C$. legalis para o reflorestamento de áreas degradadas e alteradas na região de Luiz Antonio e Pederneiras (SP), com material melhorado e de base genética ampla. Esta base combinada com a alta produtividade esperada nos caracteres de valor econômico e com a facilidade de coleta de sementes no pomar, justifica e incentiva a implantação do respectivo programa. 


\section{ConClusões}

a) A análise dos caracteres e sobrevivência revelaram um boa adaptação da espécie aos dois locais de experimentação. As diferenças no desenvolvimento dos caracteres entre locais pode ser atribuída principalmente ao ambiente, em especial às diferenças na fertilidade do solo e aos tratos culturais, como a desrama realizada em Luiz Antonio. Os melhores crescimento foram observados em Luiz Antonio e a população Campinas apresentou o melhor desempenho em ambos locais;

b) A análise do sistema de reprodução revelou que a espécie se reproduz por sistema misto, predominantemente por cruzamentos;

c) O teste de Equilibrio de Hardy-Weinberg, de homogeneidade nas freqüências do conjunto gênico do pólen e dos óvulos e a correlação de $p\left(\hat{r}_{p}\right)$ revelaram que os cruzamentos nas populações naturais de $C$. legalis não são obrigatoriamente aleatórios, gerando uma certa quantidade de indivíduos por cruzamentos entre aparentados e preferenciais;

d) A correlação de $t\left(\hat{r}_{s}\right)$ revelou que os indivíduos de autofecundação encontram-se aleatoriamente distribuídos dentro das progênies e a correlação de $p\left(\hat{r}_{p}\right)$ indicou a existência de irmãos completos dentro das progênies;

e) Os resultados obtidos para a divergência genética entre populações por caracteres quantitativos e por isoenzimas foram consistentes, evidenciando que a maior parte da variabilidade genética encontra-se dentro das populações, mais especificamente entre plantas dentro das progênies.

f) A análise da estrutura genética das populações de $C$. legalis, incluindo as populações do Estado do Espírito Santo, mostrou que a divergência genética aumenta e o fluxo gênico diminui com o aumento da distância entre as populações, sugerindo a hipótese de isolamento por distância. 
g) Os coeficientes de variação genética e variação fenotípica obtidos para os caracteres quantitativos, em concordância aos índices de diversidade, número médio de alelos por locos $(A)$, heterozigosidade observada $\left(\hat{H}_{o}\right)$ e esperada $\left(\hat{H}_{e}\right)$, obtidos a apartir das isoenzimas, sugerem que a população Vassununga apresenta a maior variabilidade genética, seguida da população Ibicatu e Campinas.

h) As análises de regressão linear revelaram razoáveis coeficientes de determinação para os caracteres forma do fuste, DAP e altura em relação à heterozigosidade observada e ao índice de fixação, indicando um bom ajuste dos dados ao modelo linear e aumento no crescimento dos caracteres com o aumento nas taxas de heterozigotos e redução nas taxas de fixação de alelos (endogamia).

i) A magnitude da depressão por endogamia observada em C. legalis foi alta para todos os caracteres.

j) A comparação na estimativa de parâmetros genéticos e ganhos na seleção, considerando as progênies como de cruzamentos aleatórios ou de cruzamentos mistos com e sem parentesco entre genitores, revelou superestimativas de até $37 \%$, indicando que, para obter-se medidas acuradas de herança e progressos genéticos, há necessidade de considerar os parâmetros do sistema de reprodução.

k) A magnitude ds ganhos preditos com a seleção para as populações foram razoáveis, encorajando o início de um programa de methoramento com a espécie C. legalis. 
ANEXos 
Tabela 49. Número de locos $(n l)$, taxa de cruzamento unilocos $\left(\hat{t}_{s}\right)$, multilocos $\left(\hat{t}_{m}\right)$, entre aparentados $\left(\hat{\boldsymbol{t}}_{p}\right)$ e de autofecundação $(\hat{\boldsymbol{S}})$ para a média de várias espécies arbóreas Angiospermas.

\begin{tabular}{|c|c|c|c|c|c|c|}
\hline Espécie & $n l$ & $\hat{t}_{s}$ & $\hat{t}_{m}$ & $\hat{t}_{p}$ & $\hat{s}$ & Autores \\
\hline Acacia auriculiformis & 8 & 0,880 & 0,925 & 0,045 & 0,075 & Moran et al. (1989) \\
\hline Acacia ouriculiformis & 5 & 0,931 & 0,963 & 0,032 & 0,037 & Khasa et al (1993) \\
\hline Acacia crassicarpa & 8 & 0,950 & 0,930 & 0 & 0,070 & Khasa et al. (1993) \\
\hline Acacia melanoxylon & 12 & 0,950 & 0,870 & 0 & 0,130 & Muona et al. (1991) \\
\hline Beilschmiedia pendula & 3 & $\ldots$ & 0,918 & $\ldots$ & 0,082 & Murawski \& Hamrick (1991) \\
\hline Bertholletia excelsa & 2 & 0,798 & 0,849 & 0,051 & 0,151 & O'Malley et al. (1988) \\
\hline Brosimum alicastrum & 7 & - & 0,875 & -- & 0,125 & Murawski \& Hamnick (1991) \\
\hline Carapa guianensis & 5 & 0,932 & 0,967 & 0,035 & 0,037 & Hall et al. (1994) \\
\hline Carya illinoinensis & 9 & 1,045 & 1,130 & 0,085 & 0 & Rüther et al. (2000) \\
\hline Cavalinesia platanifolia & 4 & 0,481 & 0,458 & 0 & 0,542 & Murawski et al. (1990) \\
\hline Cavalinesia platanifolia & 6 & 0,431 & 0,437 & 0,006 & 0,563 & Murawski \& Hamrick (1992b) \\
\hline Cecropia obtusifolia & 8 & 0,980 & 0,974 & 0 & 0,026 & Alvares Buyllla \& Garay (1994) \\
\hline Cedrella fissilis & 10 & 0,830 & 0,920 & 0,090 & 0,080 & Gandara (1996) \\
\hline Ceiba pentranda & 6 & 0,659 & 0,689 & 0,039 & 0,311 & Murawski \& Hamnick (1992a) \\
\hline Chorisia speciosa & 7 & 0,602 & 0,882 & 0,280 & 0,118 & Souza $(1997)$ \\
\hline Copaiba langsdorffi & 12 & 0,877 & 0,917 & 0,040 & 0,083 & Oliveira $(2000)$ \\
\hline Cordia alliodora & 4 & 0,958 & 0,966 & 0,008 & 0,034 & Boshier et al. (1995a) \\
\hline Couratari multiflora & 3 & 0,968 & 0,953 & 0 & 0,047 & Lepsch-Cunha (1996) \\
\hline Cryptocarya moschata & 7 & 0,752 & 0,862 & 0,100 & 0,038 & Moraes (1997) \\
\hline Dipteryx oleifera & 11 & 0,740 & 0,740 & 0 & 0,260 & Murawski \& Hamrick (1991) \\
\hline Esenbeckia letocarpa & 7 & 0,970 & 0,995 & 0,025 & 0,005 & Seoane $(1998)$ \\
\hline Eugenia dysenterica & 8 & -- & 0,835 & - & 0,165 & Telles (2000) \\
\hline Genipa americana & 8 & 0,617 & 0,816 & 0,199 & 0,184 & Sebbenn et al. (1998) \\
\hline Hevea brasiliensis & 4 & 0,643 & - & $-\cdots$ & 0,357 & Paiva et al. (1994) \\
\hline Liriodendron tulipifera & 5 & 0,650 &.- & $\cdots$ & 0,350 & Brotschol et al. (1986) \\
\hline Myracrodruon urundeuva & 3 & 0,338 & -- & -- & 0,662 & Moraes (1993) \\
\hline Ocotea tenera & 3 & 0,912 & - & -- & 0,088 & Gibson et al. (1996) \\
\hline Peltophorum dubiun & 9 & 0,874 & -- & --- & 0,126 & Mori (2000) \\
\hline Pithecellobium pedicellare & 4 & 0,936 & 0,951 & 0,015 & 0,049 & O'Malley \& Bawa (1987) \\
\hline Pithecellobium elegans & 5 & 0,997 & 0,973 & 0 & 0,027 & Hall et al. (1995) \\
\hline Platypodiun elegans & 10 & - & 0,911 & - & 0,089 & Murawski \& Hamrick (1991) \\
\hline Prosopis velutina & 8 & 0,591 & 0,609 & 0,018 & 0,391 & Keys \& Smith (1994) \\
\hline Prosopis velutina & 8 & 0,756 & 0,830 & 0,074 & 0,170 & Murawski \& Hamrick (1992b) \\
\hline Prosopis alba & 9 & 0,864 & 0,781 & 0 & 0,219 & Bessega et al. (2000) \\
\hline Prosopis nigra & 9 & 0,928 & 1,000 & 0,072 & 0 & Bessega et al. (2000) \\
\hline Prosopis chilensis & 9 & 0,687 & 0,809 & 0,122 & 0,191 & Bessega et al. (2000) \\
\hline Prosopis flexuosa & 9 & 0,876 & 0,882 & 0,006 & 0,118 & Bessega et al. (2000) \\
\hline Prosopis ruscifolia & 9 & 0,811 & 0,782 & 0 & 0,218 & Bessega et al. (2000) \\
\hline Prosopis velutina & 9 & 0,779 & 0,741 & 0 & 0,259 & Bessega et al. (2000) \\
\hline Prosopis glandulosa & 9 & 0,880 & 0,976 & 0,096 & 0,024 & Bessega et al. $(2000)$ \\
\hline
\end{tabular}


Continuação da Tabela 49.

\begin{tabular}{|c|c|c|c|c|c|c|}
\hline Espécie & $n l$ & $\hat{t}_{s}$ & $\hat{t}_{m}$ & $\hat{t}_{p}$ & $\hat{\boldsymbol{s}}$ & Autores \\
\hline Psychotria faxlucens & 6 & 1,000 & 0,997 & 0 & 0,003 & Nasser et al. (1993) \\
\hline Pterocarpus macrocarpus & 16 & 0,819 & 0,828 & 0,009 & 0,171 & Liengsiri et al. (1998) \\
\hline Robinia pseudoacacia & 16 & 0,811 & -.. & - & 0,189 & Surles et al. (1989) \\
\hline Shorea congestifolia & 6 & 0,852 & 0,874 & 0,022 & 0,126 & Murawski et al. (1994) \\
\hline Shorea trapezifolia & 4 & 0,560 & 0,580 & 0,020 & 0,420 & Murawski et al. (1994) \\
\hline Sorocea affinis & 5 & - & 0,969 & - & 0,031 & Murawski et al. (1994) \\
\hline Stemonoporus oblongifolius & 5 & 0,889 & 0,844 & 0 & 0,156 & Murawski et al. (1994) \\
\hline Tachigalia versicolor & 2 & $\ldots$ & 0,937 & -.. & 0,063 & Murawski et al. (1994) \\
\hline Tababuia cassinoide & 13 & 0,705 & 0,839 & 0,134 & 0,161 & Sebbenn et al. (2000) \\
\hline Tectona grandis & 20 & 0,920 & 0,980 & 0,060 & 0,020 & Kertadikara \& Prat (1994) \\
\hline Tectona grandis & 4 & 0,890 & 0,950 & 0,060 & 0,050 & Kjaer \& Suangtho (1995) \\
\hline$n^{\circ}$ de espécies & & 42 & 42 & 29 & 49 & \\
\hline Média entre espécies & & 0,822 & 0,880 & 0,059 & 0,120 & \\
\hline IC $95 \%$ & & $\pm 0,052$ & $\pm 0,040$ & $\pm 0,091$ & $\pm 0,042$ & \\
\hline
\end{tabular}


Tabela 50. Número de locos $(n t)$, taxa de cruzamento unilocos $\left(\hat{t}_{s}\right)$, multilocos $\left(\hat{t}_{m}\right)$, entre aparentados $\left(\hat{t}_{p}\right)$ e de autofecundação $(\hat{s})$ para a média de várias espécies do gênero Eucalyptus.

\begin{tabular}{|c|c|c|c|c|c|c|}
\hline Espécie & $n l$ & $\hat{t}_{s}$ & $\hat{t}_{m}$ & $\hat{t}_{p}$ & $\hat{\boldsymbol{s}}$ & Autores \\
\hline Eucalyptus alba & 1 & 0,770 & $\cdots$ & -- & 0,230 & Krug \& Alves (1949) \\
\hline Eucalyptus citriodora & 5 & - & 0,850 & $\ldots$ & 0,150 & Yeh et al. (1983) \\
\hline Eucalyptus delegatensis & 3 & 0,747 & 0,753 & 0,006 & 0,247 & Motan \& Brown (1980) \\
\hline Eucalyptus grandis & 4 & 0,700 & $\ldots$ & $\ldots$ & 0,300 & Hundgson (1976) \\
\hline Eucalyptus grandis & 6 & 0,840 & --- & --- & 0,260 & Brown et al. (1985) \\
\hline E. grandis $x$ E. urophylla & 11 & 0,706 & 0,702 & 0 & 0,294 & Campinhos et al. (1976) \\
\hline Eucalyptus kisoniana & 3 & 0,770 & ... & --- & 0,230 & Fripp (1982) \\
\hline Eucalyptus obliqua & 3 & 0,760 & -- & -.. & 0,240 & Brown et al. (1975) \\
\hline Eucalyptus pauciflora & 4 & 0,700 & $\ldots$ & -- & 0,300 & Phillips \& Brown (1977) \\
\hline Eucalyptus pellita & 16 & - & 0,557 & $-\cdots$ & 0,443 & House \& Bell (1996) \\
\hline Eucalyptus pilularias & 1 & 0 & -.. & -- & 1,000 & Florence (1969) \\
\hline Eucalyptus pulverulenta & 8 & 0,703 & - & -.. & 0,297 & Peters et al. (1990) \\
\hline Eucalyptus regnans & 1 & 0,720 & -.. & _- & 0,280 & Eldridge (1970) \\
\hline Eucalyptus regnans & 10 & $\ldots$ & 0,825 & -- & 0,175 & Moran et al. (1989) \\
\hline Eucalyptus remeliana & 7 & 0,800 & 0,827 & 0,027 & 0,173 & Sampson et al. (1995) \\
\hline Eucalyptus rhodantha & 4 & 0,610 & 0,580 & 0 & 0,420 & Sampson et al., (1990) \\
\hline Eucalyptus saligna & 6 & 0,770 & $-\ldots$ & -.. & 0,230 & Brown et al. (1985) \\
\hline Eucalyptus stelluata & $3-$ & 0,770 & - & -. & 0,230 & Brown et al. (1985) \\
\hline Eucalyptus stoatei & 4 & -- & 0,820 & --. & 0,180 & Happer \& Moran (1982) \\
\hline Eucalyptus urophyla & 13 & - & 0,905 & $\ldots$ & 0,095 & House \& Bell (1994) \\
\hline $\mathrm{n}^{\circ}$ de espécies & & 15 & 9 & 4 & 19 & \\
\hline Média entre espécies & & 0,650 & 0,754 & 0,104 & 0,246 & \\
\hline IC $95 \%$ & & $\pm 0,165$ & $\pm 0,089$ & $\pm 0,015$ & $\pm 0,123$ & \\
\hline
\end{tabular}

a: Marcadores morfológicos. 
Tabela 51. Número de locos $(n t)$, taxa de cruzamento unilocos $\left(\hat{t}_{s}\right)$, multilocos $\left(\hat{t}_{m}\right)$, entre aparentados $\left(\hat{t}_{p}\right)$ e de autofecundação $(\hat{s})$ para várias espécies do gênero Pinus.

\begin{tabular}{|c|c|c|c|c|c|c|}
\hline Espécie & $n l$ & $\hat{t}_{s}$ & $\hat{t}_{m}$ & $\hat{t}_{p}$ & $\hat{\boldsymbol{s}}$ & Autores \\
\hline Pinus banksiana & 5 & -.. & 0,880 & -.- & 0,120 & Cheliak et. al. (1985) \\
\hline Pinus banksiana & 5 & -. & 0,880 & -. & 0,120 & Snyder et al. (1985) \\
\hline P. caribaea bahamensis & 11 & -.. & 0,890 & $-\ldots$ & 0,110 & Matheson et al. (1989) \\
\hline P. caribaea hondurensis & 11 & - & 0,905 & - & 0,095 & Matheson et al. (1989) \\
\hline Pinus contorta & 6 & 0,962 & 0,948 & 0 & 0,052 & Perry \& Dancik (1986) \\
\hline Pinus elliottii & 12 & 0,975 & - & - & 0,250 & Squillace \& Goddard (1982) \\
\hline Pinus maximinoi & 11 & $-\ldots$ & 0,650 & $\cdots$ & 0,350 & Matheson et al. (1989) \\
\hline Pinus merkusii & 14 & 0,474 & 0,467 & 0 & 0,533 & Changtragoon \& Finkeldey (1995) \\
\hline Pinus monticola & 14 & 0,952 & 0,977 & 0,025 & 0,023 & El-Kassaby et al. (1987) \\
\hline Pinus monticola & 14 & 0,974 & 0,948 & 0 & 0,052 & Perry \& Dancik (1986) \\
\hline Pinus oocarpa & 11 & -- & 0,874 & -- & 0,126 & Matheson et al. (1989) \\
\hline Pinus ponderosa & 4 & - & 1,000 & -- & 0 & Perry \& Dancik (1986) \\
\hline Pinus ponderosa & 3 & -.. & 0,958 & -.. & 0,042 & Mitton et al. (1977) \\
\hline Pinus ponderosa & 4 & -- & 1,000 & -- & 0 & Mitton et al. (1981) \\
\hline Pinus ponderosa & 4 & -- & 0,700 & --. & 0,300 & Farris \& Mitton (1985) \\
\hline Pinus jeffireyi & 4 & -.. & 0,930 & -- & 0,070 & Furnies \& Adams (1986) \\
\hline Pinus radiata & 5 & -- & 0,740 & $-\ldots$ & 0,260 & Moran et al. (1991) \\
\hline Pinus rigida & 4 & - & 0,950 & -- & 0,050 & Guries et. al. (1985) \\
\hline Pinus sylvestris & 10 & 0,981 & 0,968 & 0 & 0,032 & Burczyk (1998) \\
\hline Pinus taeda & 7 & 0,992 & 0,994 & 0,002 & 0,006 & Friedman \& Adams (1985) \\
\hline Pinus washoensis & 4 & 0,793 & 0,863 & 0,070 & 0,137 & Mitton et al. (1997) \\
\hline $\mathrm{n}^{\circ}$ de espécies & & 8 & 20 & 7 & 21 & \\
\hline Média entre espécies & & 0,880 & 0,874 & 0 & 0,126 & \\
\hline IC $95 \%$ & & $\pm 0,159$ & $\pm 0,100$ & $\pm 0,025$ & $\pm 0,094$ & \\
\hline
\end{tabular}


Tabela 52. Número de locos $(n t)$, taxa de cruzamento unilocos $\left(\hat{t}_{s}\right)$, multilocos $\left(\hat{t}_{m}\right)$, entre aparentados $\left(\hat{t}_{p}\right)$ e de autofecundação $(\hat{s})$ para várias espécies arbóreas.

\begin{tabular}{lcccccl}
\hline \multicolumn{1}{c}{ Espécie } & $n l$ & $\hat{\boldsymbol{t}}_{s}$ & $\hat{\boldsymbol{t}}_{m}$ & $\hat{\boldsymbol{t}}_{p}$ & $\hat{\boldsymbol{s}}$ & \multicolumn{1}{c}{ Autores } \\
\hline Abies balsamae & 5 & - & 0,890 & -- & 0,110 & Neale \& Adams (1985) \\
Abies lasiocarpa & 6 & -- & 0,890 & - & 0,110 & Shea (1987) \\
Abies procera & 4 & 0,900 & 0,980 & 0,080 & 0,020 & Siegismund \& Kjaer (1997) \\
Cunninghamia konishii & 4 & 0,847 & 0,902 & 0,055 & 0,098 & Wang \& Lin (1998) \\
Larix laricina & 6 & -- & 0,530 & - & 0,470 & Knowles et al. (1987) \\
Picea abies & 6 & -- & 0,910 & -- & 0,090 & Xie \& Knowles (1994) \\
Picea engelmannii & 5 & -- & 0,930 & - & 0,070 & Shea (1987) \\
Picea glauca & 6 & -- & 0,945 & - & 0,055 & Cheliak et al. (1985) \\
Picea mariana & 6 & 0,558 & 0,618 & 0,060 & 0,076 & Sproule \& Dancik (1996) \\
Psendotsuga menziesii & 6 & 0,936 & 0,955 & 0,019 & 0,045 & El-Kassaby et al. (1986) \\
Thuja occidentalis & 8 & -- & 0,510 & - & 0,490 & Perry \& Knowles (1991) \\
Thuja plicata & 9 & -- & 0,230 & -- & 0,770 & El-Kassaby et al. (1994) \\
\hline $\mathrm{n}^{\circ}$ de espécies & & 4 & 12 & 4 & 12 & \\
Média entre espécies & & 0,811 & 0,792 & 0 & 0,208 & \\
IC 95\% & $\pm 0,190$ & $\pm 0,150$ & $\pm 0,052$ & $\pm 0,153$ & \\
\hline
\end{tabular}

Tabela 53. Espécies, populações (Pop), coeficiente de variação genética entre progênies $\left(C V_{g}\right)$, coeficiente de variação fenotípica dentro de progênies $\left(C V_{d}\right)$, coeficientes de herdabilidade no sentido restrito em nível de plantas $\left(\hat{h}_{t}^{2}\right)$ para altura e DAP.

\begin{tabular}{|c|c|c|c|c|c|c|c|c|}
\hline \multirow[t]{2}{*}{ Espécie } & \multirow[b]{2}{*}{ Pop } & \multicolumn{3}{|c|}{ Altura } & \multicolumn{3}{|c|}{ DAP } & \\
\hline & & $C V_{g}$ & $C V_{d}$ & $\hat{h}_{i}^{2}$ & $C V_{g}$ & $C V_{d}$ & $\hat{h}_{1}^{2}$ & \\
\hline Acacia mearnsil & 2 & 6,3 & - & 0,26 & 9,8 & $\ldots$ & 0,30 & Resende et al. (1992) \\
\hline Araucaria angustifolia & 3 & 7,3 & $\ldots$ & 0,09 & - & $\ldots$ & $\ldots$ & Gianotti et al. (1982) \\
\hline Balphorodredun riedelianun & 3 & 5,8 & 28,2 & 0,09 & 4,2 & 24,7 & 0,13 & Siqueira et al. (2000) \\
\hline Cariniana legalis & 3 & 6,4 & 21,2 & 0,13 & 5,2 & 30,3 & 0,11 & Sebbenn et al., (2000) \\
\hline Cordia trichotoma & 3 & 4,3 & 19,9 & 0,10 & 5,7 & 29,3 & 0,17 & Ettori et al. (1999) \\
\hline Cecropia cinerea & 1 & 3,9 & 10,3 & 0,50 & - & $\ldots$ & $\ldots$ & Siqueira et al. (1986a) \\
\hline Dipterix alata & 5 & 7,1 & 26,3 & 0,33 & 7,7 & 32,0 & 0,30 & Siqqueira et al. (1993) \\
\hline Esenbeckia leiocarpa & 2 & 16,7 & 33,1 & 0,77 & - & --- & - & Vitti et al. (1992) \\
\hline Galesia gorarema & 3 & 0,8 & 14,8 & 0,14 & 2,6 & 60,7 & 0,0 & Noguteira et al., (1986c) \\
\hline Miracrodruon urundewva & 2 & 4,5 & 26,5 & 0,35 & $\ldots$ & $\ldots$ & $\ldots$ & Moraes (1993) \\
\hline Myroxylon peruiferum & 5 & 11,7 & 49,5 & 0,19 & 6,6 & 24,1 & 0,19 & Sebbenn et al. (1998) \\
\hline Peltophortm dubiun & 2 & 8,5 & 17,2 & 0,64 & 15,3 & 26,3 & 0,76 & Sebbenn et al. (1999) \\
\hline Pterogyne nitens & 4 & 12,7 & 33,3 & 0,47 & 12,5 & 51,5 & 0,21 & Sebbern et al. (2000) \\
\hline Tabebuia vellosoi & 2 & 14,0 & 30,8 & 0,61 & 11,7 & 42,1 & 0,02 & Ettori et al. (1995) \\
\hline Tabeabuia heptaphila & 1 & 2,9 & 18,5 & 0,09 & 5,6 & 30,6 & 0,12 & Ettori et al. (1996) \\
\hline Média para espécies & & 7,49 & 25,36 & 0,32 & 7,91 & 35,15 & 0,22 & \\
\hline IC $(95 \%)$ & \pm & 2,48 & 6,16 & 0,13 & 2,65 & 8,81 & 0,14 & \\
\hline
\end{tabular}


Tabela 54. Significância do teste $F$ para os quadrados médios $(Q M)$ da análise da variância individual do caracteres em três populações de $C$. legalis em Luiz Antonio, SP.

\begin{tabular}{|c|c|c|c|c|c|c|c|c|c|c|}
\hline \multirow[b]{2}{*}{ FV } & \multirow[b]{2}{*}{ GL } & \multicolumn{2}{|c|}{ FF } & \multicolumn{2}{|c|}{$\mathrm{DAP}(\mathrm{cm})$} & \multicolumn{2}{|c|}{ Altura (m) } & \multicolumn{2}{|c|}{$\operatorname{VC}\left(\mathrm{m}^{3}\right)$} & \multirow{2}{*}{$\frac{\mathrm{SOB}}{\mathrm{QM}}$} \\
\hline & & $\mathrm{QM}$ & & $\mathrm{QM}$ & & $\mathrm{QM}$ & $\mathrm{F}$ & $\mathrm{QM}$ & & \\
\hline Blocos & 5 & 0,0050 & & 10,0900 & & 24,6490 & & 0,0364 & & 2458,228 \\
\hline Populacioes (Pop) & 2 & 0,0829 & & 38,8504 & & 21,8880 & & 0,0415 & & 2180,716 \\
\hline Erro (a) & 10 & 0,2242 & & 24,8539 & & 43,0945 & & 0,0689 & & 1642,876 \\
\hline Progénies/Pop. & 47 & 0,0554 & $* *$ & 11,7726 & ** & 5,9904 & $+*$ & 0,0186 & ** & 512,1875 \\
\hline Prog/Pop. 1 & 16 & 0,0304 & & 10,2965 & \# & 3,8520 & & 0,0177 & * & 469,7870 \\
\hline Prog/Pop. 2 & 15 & 0,0933 & ** & 11,0711 & ** & 8,0894 & ** & 0,0171 & & 367,2028 \\
\hline Prog.Pop. 3 & 16 & 0,0345 & & 9,0502 & & 3,4249 & & 0,0157 & & 417,9219 \\
\hline Erro (b) & 235 & 0,0284 & & 5,6807 & & 3,0448 & & 0,0105 & & 465,6341 \\
\hline Indiv./Prog/Pop. & 990 & 0,0837 & & 23,8176 & & 9,1021 & & 0,0422 & & -..- \\
\hline Indiv.Prog/Pop. 1 & 342 & 0,0830 & & 23,1195 & & 9,4802 & & 0,0407 & & -... \\
\hline Indiv.Prog/Pop. 2 & 295 & 0,0793 & & 23,1354 & & 9,0066 & & 0,0380 & & -... \\
\hline Indiv./Prog/Pop. 3 & 353 & 0,0881 & & 25,0640 & & 8,8157 & & 0,0472 & & $\ldots$ \\
\hline $\mathrm{CV}_{0 \times p}$ & & $8,8 \%$ & & $17,7 \%$ & & $14,2 \%$ & & $44,7 \%$ & & $31,4 \%$ \\
\hline
\end{tabular}

$*: P \leq 0,05 ; * *: P \leq 0,01$

Pop1: Campinas $=17$ progênies; Pop2: Ibicatu $=16$ progênies; Pop3: Vassununga $=17$ progênies .

Tabela 55. Significância do teste $F$ para os quadrados médios $(\mathrm{QM})$ da análise da variância individual dos caracteres em três populações de C. legalis em Pederneiras, SP.

\begin{tabular}{|c|c|c|c|c|c|c|c|c|c|c|c|}
\hline \multirow[b]{2}{*}{ FV } & \multirow[b]{2}{*}{ GL } & \multicolumn{2}{|c|}{ FF } & \multicolumn{2}{|c|}{ DAP $(\mathrm{cm})$} & \multicolumn{2}{|c|}{ Altura (m) } & \multicolumn{2}{|c|}{$\mathrm{VC}\left(\mathrm{m}^{3}\right)$} & \multicolumn{2}{|l|}{ SOB } \\
\hline & & $\mathrm{QM}$ & & $\mathrm{QM}$ & & $\mathrm{QM}$ & $\mathbf{F}$ & QM & & $\mathrm{QM}$ & \\
\hline Blocos & 5 & 0,1813 & & 39,0953 & $\%$ & 38,6720 & * & 0,0466 & * & 2458,2280 & \\
\hline Populaçes (Pop) & 2 & 0,6470 & * & 55,6853 & & 9,9185 & & 0,0360 & & 2180,7158 & \\
\hline Erro $(a)$ & 10 & 0,1015 & & 9,9208 & & 9,9421 & & 0,0108 & & 1642,8760 & \\
\hline Progénies/Pop. & 52 & 0,0608 & $\Rightarrow$ & 8,4449 & \$क & 2,9173 & 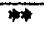 & 0,0057 & का & 512,1875 & $\rightarrow$ \\
\hline Prog. Pop. 1 & 16 & 0,0334 & & 7,8519 & 中* & 2,1760 & 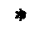 & 0,0052 & $*$ & 469,7870 & \\
\hline Prog./Pop. 2 & 15 & 0,0339 & & 4,9494 & & 1,7774 & & 0,0028 & & 367,2028 & \\
\hline Prog $/$ Pop. 3 & 21 & 0,0392 & 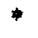 & 6,0901 & * & 3,3518 & ** & 0,0047 & * & 417,9219 & ** \\
\hline Erto (b) & 260 & 0,0277 & & 3,8094 & & 1,3193 & & 0,0028 & & 465,6341 & \\
\hline Ind/Prog/Pop. & 977 & 0,0576 & & 14,8476 & & 3,9269 & & 0,0104 & & $\ldots$ & \\
\hline Indiv /Prog/Pop 1 & 323 & 0,0618 & & 15,0875 & & 3,1864 & & 0,0110 & & $\ldots$ & \\
\hline Indiv./Prog/Pop 2 & 291 & 0,0504 & & 13,8431 & & 4,3673 & & 0,0084 & & $\cdots$ & \\
\hline Indiv./Prog/Pop. 3 & 363 & 0,0596 & & 15,4394 & & 4,2327 & & 0,0118 & & $-m$ & \\
\hline $\mathrm{CV}_{\text {4x }}$ & & $8.7 \%$ & & $15,5 \%$ & & $12,4 \%$ & & $37,5 \%$ & & $23,0 \%$ & \\
\hline
\end{tabular}

*: $P \leq 0,05 ;{ }^{* *}: P \leq 0,01$;

Popl: Campinas $=17$ progênies; Pop2: Ibicatu $=16$ progênies; Pop3: Vassununga $=22$ progênies. 
Tabela 56. Significância do teste $F$ para os quadrados médios $(Q M)$ da análise da variância conjunta para locais em três populações de C. legalis.

\begin{tabular}{|c|c|c|c|c|c|c|c|c|c|c|}
\hline \multirow[b]{2}{*}{ FV } & \multirow[b]{2}{*}{ GL } & \multicolumn{2}{|c|}{$\mathrm{FF}$} & \multicolumn{2}{|c|}{$\mathrm{DAP}(\mathrm{cm})$} & \multicolumn{2}{|c|}{ Altura (m) } & \multicolumn{2}{|c|}{$\mathrm{VC}\left(\mathrm{m}^{3}\right)$} & \multirow{2}{*}{$\frac{\mathrm{SOB}}{\mathrm{QM}}$} \\
\hline & & $\mathrm{QM}$ & & $\mathrm{QM}$ & & $\mathrm{QM}$ & $F$ & $\mathrm{QM}$ & & \\
\hline Blocos/Locais & 10 & 0,0862 & & 22,1533 & & 29,9059 & & 0,0397 & & 1915,8256 \\
\hline Locais (L) & 1 & 0,3216 & ** & 5,2316 & ** & 77,5390 & ** & 0,0677 & \#* & $\mathbf{0 , 3 3 7 2}$ \\
\hline Populaçós (P) & 2 & 0,0292 & & 4,4005 & & 1,0262 & & 0,0035 & & 46,1314 \\
\hline $\mathbf{L} \times \mathbf{P}$ & 2 & 0,0116 & & 0,4502 & & 0,8661 & & 0,0007 & & 186,3567 \\
\hline Erro (a) & 20 & 0,1626 & & 17,4352 & & 26,6669 & & 0,0397 & & 1328,4651 \\
\hline Prog./Pop. (P/P) & 47 & 0,0679 & \# & 14,2722 & 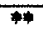 & 5,2839 & 7 & 0,0149 & th & 479,8308 \\
\hline$L \times P / P$ & 47 & 0,0453 & $* *$ & 5,9881 & & 3,1505 & * & 0,0093 & 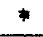 & 432,4682 \\
\hline Prog.Pop. 1 (P/P1) & 16 & 0,0243 & & 9,8778 & & 3,7153 & & 0,0105 & & 376,4358 \\
\hline Prog $/ \mathrm{Pop} .2(\mathrm{P} / \mathrm{P} 2)$ & 15 & 0,0752 & ** & 11,0456 & & 6,4261 & & 0,0109 & & 497,4740 \\
\hline Prog./Pop. 3 (P/P3) & 16 & 0,0427 & & 12,3720 & * & 3,6452 & & 0,0158 & $*$ & 471,7306 \\
\hline $\mathrm{L} \times \mathrm{P} / \mathrm{PI}$ & 16 & 0,0395 & & 8,2706 & $*$ & 2,3126 & & 0,0124 & * & 413,9518 \\
\hline $\mathrm{L} \times \mathrm{P} / \mathrm{P} 2$ & 15 & 0,0520 & & 4,9749 & & 3,4407 & & 0,0093 & & 149,9582 \\
\hline$L \times P / P 3$ & 16 & 0,0205 & & 3,7323 & & 1,9402 & & 0,0050 & & 325,7605 \\
\hline Erro (b) & 470 & 0,0246 & & 4,7971 & & 2,1690 & & 0,0067 & & -... \\
\hline Indiv /Prog $/$ Pop. & 1967 & 0,0707 & & 19,3628 & & 6,5316 & & 0,0273 & & $m$ \\
\hline Indiv./Prog/Pop. 1 & 665 & 0,0727 & & 19,2198 & & 6,4232 & & 0,0263 & & $\cdots$ \\
\hline Indiv $/$ Prog $/$ Pop. 2 & 586 & 0,0649 & & 18,5210 & & 6,7028 & & 0,0233 & & $\ldots$ \\
\hline Indiv./Prog/Pop. 3 & 716 & 0,0737 & & 20,1845 & & 6,4922 & & 0,0321 & & $\ldots$ \\
\hline $\mathrm{CV}_{\mathrm{np}}$ & & $8,6 \%$ & & $16,7 \%$ & & $13,6 \%$ & & $43,8 \%$ & & $27,4 \%$ \\
\hline$\hat{r}_{g a}$ & 50 & 0,18 & & 0,83 & & 0,68 & & 0,36 & & $-0,18$ \\
\hline $\begin{array}{l}S(\%) \\
C(\%)\end{array}$ & $\begin{array}{l}50 \\
50\end{array}$ & $\begin{array}{r}3,7 \\
96,3\end{array}$ & & $\begin{array}{c}98,6 \\
1,4\end{array}$ & & $\begin{array}{c}91,4 \\
8,6\end{array}$ & & $\begin{array}{c}1,0 \\
99,0\end{array}$ & & $\begin{array}{c}0,6 \\
96,4\end{array}$ \\
\hline
\end{tabular}

${ }^{*}: P \leq 0,05 ;{ }^{* *}: P \leq 0,01$;

a: Utilizaram-se apenas os tratamentos que eram comuns para os dois ensaios, assim Popl: Campinas $=17$ progênies; Pop2: Ibicatu $=16$ progênies; $P$ op3: Vassununga $=17$ progênies. 
Tabela 57. Significância do teste $F$ para os quadrados médios (QM) da análise da variância individual dos caracteres em três populações de $C$. legalis em Pederneiras, SP.

\begin{tabular}{|c|c|c|c|c|c|c|c|c|c|c|c|}
\hline \multirow[b]{2}{*}{ FV } & \multirow[b]{2}{*}{ GL } & \multicolumn{2}{|c|}{ FF } & \multicolumn{2}{|c|}{$\overline{D A P}(\mathrm{~cm})$} & \multicolumn{2}{|c|}{ Altura $(m)$} & \multicolumn{2}{|c|}{$V C\left(m^{3}\right)$} & \multicolumn{2}{|l|}{ SOB } \\
\hline & & $\mathrm{QM}$ & & $\mathrm{QM}$ & & $\mathbf{Q M}$ & $F$ & $\mathrm{QM}$ & & $\mathrm{QM}$ & \\
\hline Blocos & 5 & 0,1673 & & 34,2165 & & 35,1628 & & 0,0429 & & 1373,4232 & \\
\hline Populaçбes (Pop) & 2 & 0,6083 & & 43,0923 & & 9,4119 & & 0,2770 & & 1699,5392 & \\
\hline Erro (a) & 10 & 0,1010 & & 10,0164 & & 10,2394 & & 0,0105 & & 1014,0542 & \\
\hline Progénies/Pop. & 47 & 0,0578 & ** & 8,4877 & * & 2,4440 & \%" & 0,0057 & $\Rightarrow$ & 400,1115 & $*$ \\
\hline Prog/Pop. 1 & 16 & 0,0334 & & 7,8519 & * & 2,1760 & & 0,0052 & $*$ & 320,6007 & \\
\hline Prog/Pop. 2 & 15 & 0,0339 & & 4,9494 & & 1,7774 & & 0,0032 & & 280,2294 & \\
\hline Prog $/$ Pop. 3 & 16 & 0,0287 & & 7,0541 & * & 2,1605 & & 0,0051 & * & 379,5693 & \\
\hline Erro (b) & 235 & 0,0208 & & 3,8134 & & 1,2932 & & 0,0028 & & 243,2693 & \\
\hline Indiv/Prog/Pop. & 977 & 0,0576 & & 14,8476 & & 3,9269 & & 0,0104 & & $\ldots$ & \\
\hline Indiv./Prog/Pop. 1 & 323 & 0,0618 & & 15,0875 & & 3,1864 & & 0,0110 & & $\cdots$ & \\
\hline hdiv./Prog/Pop. 2 & 291 & 0,0504 & & 13,8431 & & 4,3673 & & 0,0084 & & --- & \\
\hline Indiv./Prog/Pop. 3 & 363 & 0,0596 & & 15,4394 & & 4,2327 & & 0,0118 & & $\ldots$ & \\
\hline $\mathrm{CV}_{\mathrm{sp}}$ & & $8,3 \%$ & & $15,5 \%$ & & $12,2 \%$ & & $37,0 \%$ & & $22,8 \%$ & \\
\hline
\end{tabular}

${ }^{*}: P \leq 0,05 ;{ }^{* *}: P \leq 0,01$;

Pop1: Campinas $=17$ progênies; Pop2: Ibicatu $=16$ progênies; Pop3: Vassununga $=17$ progênies. 
Tabela 58. Frequeências alélicas, divergência genética entre populações e teste de quiquadrado $\left(\chi^{2}\right)$ para adultos de $C$. legalis

\begin{tabular}{|c|c|c|c|c|c|c|c|}
\hline Loco & Alelo & Pop. Campinas & Pop. Ibicatu & Pop. Vassununga & & $\hat{F}_{S T}$ & $\chi^{2}$ \\
\hline \multirow[t]{2}{*}{ Acp-3 } & 1 & 0,853 & 0,781 & 0,864 & & & [2] \\
\hline & 2 & 0,147 & 0,219 & 0,136 & & 0,009 & 1,03 \\
\hline \multirow[t]{4}{*}{ Est-1 } & 1 & 0,389 & 0,364 & 0,304 & & & \\
\hline & 2 & 0,556 & 0,576 & 0,652 & & & \\
\hline & 3 & 0,028 & 0,030 & 0,022 & & & [6] \\
\hline & 4 & 0,028 & 0,030 & 0,022 & & 0,006 & 2,07 \\
\hline \multirow[t]{4}{*}{ Est-2 } & 1 & 0,441 & 0,364 & 0,422 & & & \\
\hline & 2 & 0,529 & 0,545 & 0,533 & & & \\
\hline & 3 & 0,029 & 0,061 & 0,022 & & & [6] \\
\hline & 4 & 0 & 0,030 & 0,022 & & 0,003 & 0,87 \\
\hline \multirow[t]{4}{*}{ Pgi-1 } & 1 & 0,912 & 0,824 & 0,891 & & & \\
\hline & 2 & 0,088 & 0,118 & 0,065 & & & \\
\hline & 3 & 0 & 0,029 & 0,022 & & & {$[6]$} \\
\hline & 4 & 0 & 0,029 & 0,022 & & 0,009 & 3,03 \\
\hline \multirow[t]{3}{*}{ Pgi-2 } & 1 & 0,486 & 0,424 & 0,489 & & & \\
\hline & 2 & 0,486 & 0,545 & 0,489 & & & [4] \\
\hline & 3 & 0,029 & 0,031 & 0,022 & & 0,003 & 0,64 \\
\hline \multirow[t]{3}{*}{ Mdh-1 } & 1 & 0,429 & 0,469 & 0,356 & & & \\
\hline & 2 & 0,543 & 0,531 & 0,622 & & & [4] \\
\hline & 3 & 0,029 & 0 & 0,022 & & 0,008 & 1,82 \\
\hline \multirow[t]{3}{*}{ Mdh-2 } & 1 & 0,657 & 0,594 & 0,578 & & & \\
\hline & 2 & 0,314 & 0,406 & 0,400 & & & [4] \\
\hline & 3 & 0,029 & 0 & 0,022 & & 0,006 & 1,34 \\
\hline \multirow[t]{3}{*}{ Prx-1 } & 1 & 0,686 & 0,656 & 0,600 & & & \\
\hline & 2 & 0,286 & 0,344 & 0,378 & & & [4] \\
\hline & 3 & 0,029 & 0 & 0,022 & & 0,006 & 1,39 \\
\hline \multirow[t]{3}{*}{ Prx-2 } & 1 & 0,529 & 0,625 & 0,711 & & & \\
\hline & 2 & 0,411 & 0,281 & 0,267 & & & [4] \\
\hline & 3 & 0,029 & 0,094 & 0,022 & & 0,026 & 5,69 \\
\hline \multirow[t]{4}{*}{$\operatorname{Prx}-3$} & 1 & 0,676 & 0,706 & 0,534 & & & \\
\hline & 2 & 0,294 & 0,235 & 0,413 & & & \\
\hline & 3 & 0,029 & 0,029 & 0,022 & & & [6] \\
\hline & 4 & 0 & 0,030 & 0,022 & & 0,023 & 7,52 \\
\hline \multirow[t]{3}{*}{ 6Pgdh-1 } & 1 & 0,057 & 0,152 & 0,111 & & & \\
\hline & 2 & 0,914 & 0,818 & 0,867 & & & [4] \\
\hline & 3 & 0,029 & 0,030 & 0,022 & & 0,012 & 2,58 \\
\hline \multirow[t]{2}{*}{ Skdh-1 } & 1 & 0,235 & 0,500 & 0,545 & & & [2] \\
\hline & 2 & 0,765 & 0,500 & 0,455 & & $0,075^{*}$ & 8,24 \\
\hline \multirow[t]{2}{*}{ G6pdh1 } & 1 & 0,971 & 0,844 & 0,987 & & & [2] \\
\hline & 2 & 0,029 & 0,156 & 0,022 & & $0,069^{*}$ & 7,59 \\
\hline \multirow{2}{*}{ Idh-1 } & 1 & 0,794 & 0,688 & 0,705 & & & {$[2]$} \\
\hline & & 0,206 & 0,312 & 0,295 & \multicolumn{3}{|c|}{$0,069 * 7,59$} \\
\hline \multicolumn{2}{|c|}{ Total de alelos } & 38 & 39 & 42 & $\hat{\bar{F}}_{S T}$ & $\begin{array}{r}0,0 \\
(0,008\end{array}$ & 3 \\
\hline
\end{tabular}

[]: Graus de liberdade;

(): Enro padrão da média;

$*: P \leq 0,05 ; * *: P \leq 0,01$

a: Significância obtida a partir de reamostragem Jeckknif. 
Tabela 59. Freqüências alélicas nas progênies e tamanho amostral (n) para três populações de C. legalis.

\begin{tabular}{|c|c|c|c|c|c|c|c|}
\hline \multirow[b]{2}{*}{ Loco } & \multicolumn{3}{|c|}{ População } & \multirow[b]{2}{*}{ Loco } & \multicolumn{3}{|c|}{ População } \\
\hline & Campinas. & Ibicatu & Vassun. & & Campinas & Ibicatu & Vassun. \\
\hline Acp-3 & & & & Skdh-1 & & & \\
\hline$(n)$ & 379 & 380 & 430 & $(n)$ & 405 & 363 & 434 \\
\hline 1 & 0,885 & 0,808 & 0,848 & 1 & 0,246 & 0,479 & 0,543 \\
\hline 2 & 0,115 & 0,192 & 0,152 & 2 & 0,754 & 0,521 & 0,457 \\
\hline$\alpha$ Est-1 & & & & Prx-1 & & & \\
\hline$(n)$ & 399 & 384 & 435 & $(n)$ & 410 & 385 & 435 \\
\hline 1 & 0,242 & 0,203 & 0,221 & 1 & 0,839 & 0,870 & 0,844 \\
\hline 2 & 0,726 & 0,757 & 0,744 & 2 & 0,160 & 0,130 & 0,154 \\
\hline 3 & 0,029 & 0,038 & 0,032 & 3 & 0,001 & 0 & 0,002 \\
\hline 4 & 0,004 & 0,003 & 0,003 & & & & \\
\hline$\alpha$ Est-2 & & & & Prx-2 & & & \\
\hline$(n)$ & 398 & 383 & 435 & $(n)$ & 406 & 385 & 435 \\
\hline 1 & 0,307 & 0,260 & 0,310 & 1 & 0,538 & 0,694 & 0,697 \\
\hline 2 & 0,633 & 0,681 & 0,634 & 2 & 0,414 & 0,265 & 0,282 \\
\hline 3 & 0,060 & 0,056 & 0,051 & 3 & 0,048 & 0,042 & 0,022 \\
\hline 4 & 0 & 0,003 & 0,005 & & & & \\
\hline Pgi-1 & & & & PTx-3 & & & \\
\hline$(n)$ & 392 & 380 & 434 & $(n)$ & 405 & 380 & 419 \\
\hline 1 & 0,918 & 0,928 & 0,919 & 1 & 0,667 & 0,707 & 0,604 \\
\hline 2 & 0,082 & 0,066 & 0,078 & 2 & 0,312 & 0,272 & 0,375 \\
\hline 3 & 0 & 0,005 & 0,001 & 3 & 0,021 & 0,020 & 0,018 \\
\hline 4 & 0 & 0,001 & 0,001 & 4 & 0 & 0,001 & 0,004 \\
\hline Pgi-2 & & & & 6Pgdhl & & & \\
\hline$(n)$ & 403 & 382 & 431 & (n) & 399 & 379 & 436 \\
\hline 1 & 0,347 & 0,313 & 0,363 & 1 & 0,109 & 0,140 & 0,136 \\
\hline 2 & 0,614 & 0,662 & 0,613 & 2 & 0,886 & 0,859 & 0,857 \\
\hline 3 & 0,038 & 0,025 & 0,024 & 3 & 0,005 & 0,001 & 0,007 \\
\hline Mdh-1 & & & & G6pdhl & & & \\
\hline$(n)$ & 410 & 386 & 436 & (n) & 404 & 363 & 430 \\
\hline 1 & 0,299 & 0,304 & 0,302 & 1 & 0,941 & 0,916 & 0,935 \\
\hline 2 & 0,695 & 0,696 & 0,694 & 2 & 0,059 & 0,084 & 0,065 \\
\hline 3 & 0,006 & 0 & 0,005 & & & & \\
\hline Mdh-2 & & & & Idh-1 & & & \\
\hline$(n)$ & 410 & 385 & 435 & $(n)$ & 398 & 360 & 422 \\
\hline 1 & 0,761 & 0,764 & 0,705 & 1 & 0,774 & 0,774 & 0,703 \\
\hline 2 & 0,235 & 0,236 & 0,289 & 2 & 0,226 & 0,226 & 0,297 \\
\hline \multirow[t]{2}{*}{3} & 0,004 & 0 & 0,007 & & & & \\
\hline & & & Tota & & 38 & 39 & 42 \\
\hline
\end{tabular}


Tabela 60. Porcentagem da variância genética aditiva $\left(\hat{\sigma}_{A}^{2}\right)$ e de dominância $\left(\hat{\sigma}_{D}^{2}\right)$ que contribuem para a variância genética entre progênies no caracteres altura (ALT), DAP, volume (VC) e forma do fuste (FF) em várias espécies florestais.

\begin{tabular}{|c|c|c|c|c|}
\hline Espécie & Caráter & $\hat{\sigma}_{A}^{2}(\%)$ & $\hat{\sigma}_{D}^{2}(\%)$ & Autor \\
\hline \multirow[t]{3}{*}{ Euc. urophylla $x$ grandis } & ALT & 61,9 & 38,1 & \multirow[t]{3}{*}{ Bouvet \& Vigneron (1996) } \\
\hline & DAP & 82,1 & 17,9 & \\
\hline & $\mathrm{VC}$ & 84,3 & 15,7 & \\
\hline \multirow[t]{3}{*}{ Euc. urophylla $x$ pellita } & $\mathrm{ALT}$ & 56,3 & 43,7 & \multirow[t]{3}{*}{ Bouvet \& Vigneton (1996) } \\
\hline & DAP & 39,9 & 60,1 & \\
\hline & $\mathrm{VC}$ & 71,4 & 28,6 & \\
\hline \multirow[t]{7}{*}{ Eucalyptus regnans } & ALT & 64,4 & 35,6 & \multirow[t]{7}{*}{ Griffin \& Cotterill (1988) } \\
\hline & DAP & 79,3 & 20,7 & \\
\hline & $\mathrm{VC}$ & 100,0 & 0,0 & \\
\hline & \multicolumn{3}{|c|}{ Média - espécies de Eucalyptus } & \\
\hline & ALT & 60,9 & 39,1 & \\
\hline & DAP & 67,1 & 32,9 & \\
\hline & $\mathrm{VC}$ & 85,2 & 14,8 & \\
\hline Pinus taeda & FF & 95,8 & 4,2 & $\begin{array}{l}\text { Shelbourne \& Stonecypher } \\
\text { (1969) }\end{array}$ \\
\hline \multirow[t]{2}{*}{ Pinus cembra } & ALT & 44,7 & 53,3 & \multirow[t]{2}{*}{ Blada (1999) } \\
\hline & DAP & 46,4 & 53,6 & \\
\hline \multirow{4}{*}{$\begin{array}{l}\text { Pinus pinaster } \\
*\end{array}$} & ALT & 100,0 & 0,0 & \multirow[t]{4}{*}{ Cotterill et al. (1987) } \\
\hline & DAP & 44,8 & 55,2 & \\
\hline & VC & 55,1 & 44,9 & \\
\hline & $\mathrm{FF}$ & 53,3 & 46,7 & \\
\hline \multirow[t]{4}{*}{ Pinus radiata } & AlT & 100,0 & 0,0 & \multirow[t]{4}{*}{ Cotterill et al. (1987) } \\
\hline & DAP & 80,8 & 19,2 & \\
\hline & VC & 68,4 & 31,6 & \\
\hline & $\mathrm{FF}$ & 62,1 & 37,9 & \\
\hline \multirow[t]{4}{*}{ Pinus elliotti } & ALT & 100,0 & 0,0 & \multirow[t]{4}{*}{ Cotterill et al. (1987) } \\
\hline & DAP & 88,4 & 11,6 & \\
\hline & $\mathrm{VC}$ & 83,3 & 16,7 & \\
\hline & $\mathrm{FF}$ & 69,7 & 30,3 & \\
\hline
\end{tabular}


Continuação da Tabela 60.

\begin{tabular}{|c|c|c|c|c|}
\hline Espécie & Caráter & $\hat{\sigma}_{A}^{2}(\%)$ & $\hat{\sigma}_{D}^{2}(\%)$ & Autor \\
\hline Pimus strobus & ALT & 81,0 & 19,0 & Kriebel et al. (1969) \\
\hline \multirow[t]{7}{*}{ Pinus silvestris } & ALT & 65,2 & 34,8 & Fries \& Ericsson (1998); \\
\hline & DAP & 26,0 & 74,0 & Ericsson (1999) \\
\hline & \multicolumn{3}{|c|}{ Média - espécies de Pinus } & \\
\hline & ALT & 84,4 & 15,6 & \\
\hline & DAP & 57,3 & 42,7 & \\
\hline & VC & 68,9 & 31,1 & \\
\hline & $\mathrm{FF}$ & 70,2 & 29,8 & \\
\hline Picea abies & DAP & 21,7 & 78,3 & Sitva et al. (2000) \\
\hline Pseudotsuga meziensii & ALT & 84,8 & 21,2 & Sorensen \& White (1988) \\
\hline \multirow{8}{*}{ Pseudotsuga meziensii } & ALT & 97,4 & 2,6 & Yeh \& Heaman (1987) \\
\hline & DAP & 46,9 & 53,1 & \\
\hline & $\mathrm{VC}$ & 42,6 & 57,4 & \\
\hline & \multicolumn{3}{|c|}{ Médias - espécies florestais } & \\
\hline & ALT & 78,8 & 21,2 & \\
\hline & DAP & 57,1 & 42,9 & \\
\hline & $\mathrm{VC}$ & 65,6 & 34,4 & \\
\hline & FF & 70,2 & 35,7 & \\
\hline
\end{tabular}

Tabela 61. Percentual (\%) da superestimativa da variância genética aditiva, quando se assume que a espécie é de reprodução mista com parentesco $(\mathrm{MS} ; \hat{\theta} \neq 0)$ e sem parentesco na geração de genitores $(\mathrm{MS} ; \hat{\theta}=0)$ em ralação a progênies de meios irmãos sem parentesco.

\begin{tabular}{clcccc}
\hline & & \multicolumn{2}{c}{ E. E. Luiz Antonio } & \multicolumn{2}{c}{ E. E. Pedemeiras } \\
\hline Caráter & \multicolumn{1}{c}{ Pop. } & MS; $\hat{\theta} \neq 0$ & MS; $\hat{\theta}=0$ & MS; $\hat{\theta} \neq 0$ & MS; $\hat{\theta}=0$ \\
\hline \multirow{3}{*}{ FF } & Campinas & 15,4 & 25,1 & 19,8 & 25,3 \\
& Ibicatu & 19,4 & 24,9 & 19,4 & 24,3 \\
& Vassununga & 22,5 & 27,5 & 22,8 & 28,2 \\
\hline \multirow{3}{*}{ DAP } & Campinas & 19,8 & 25,3 & 19,8 & 25,3 \\
& Ibicatu & 19,4 & 24,9 & 19,4 & 24,9 \\
& Vassunumga & 22,8 & 27,9 & 22,8 & 28,0 \\
\hline \multirow{3}{*}{ Altura } & Campinas & 19,8 & 25,3 & 19,8 & 25,3 \\
& Ibicau & 19,4 & 24,9 & 19,4 & 24,9 \\
& Vassumunga & 22,8 & 27,9 & 22,8 & 28,0 \\
\hline \multirow{3}{*}{ Vol. Cilindr. } & Campinas & 20,8 & 25,0 & 18,7 & 25,0 \\
& Ibicatu & 18,6 & 23,3 & 18,6 & 90,0 \\
& Vassununga & 23,5 & 26,5 & 23,1 & 30,8 \\
\hline
\end{tabular}


Tabela 62. Percentual (\%) das superestimativas dos coeficientes de herdabilidade, quando se assume que a espécie é de reprodução mista com parentesco (MS; $\hat{\theta} \neq 0$ ) e sem parentesco na geração de genitores $(\mathrm{MS} ; \hat{\theta}=0)$ em ralação a progênies de meios irmãos sem parentesco.

\begin{tabular}{|c|c|c|c|c|c|c|c|c|c|c|c|c|c|}
\hline & \multicolumn{3}{|c|}{ Forma do Fuste } & \multicolumn{3}{|c|}{ DAP } & \multicolumn{3}{|c|}{ Altura } & \multicolumn{3}{|c|}{ Volume Cilíndrico } \\
\hline & & Cam. & Ibic. & Vas. & Cam. & Ibic. & Vas. & Cam. & Ibic. & Vas. & Cam. & Ibic. & Vas \\
\hline \multicolumn{14}{|c|}{ E. E. Luiz Antonio } \\
\hline $\mathrm{MS} ; \hat{\theta} \neq 0$ & $\hat{\hat{h}}_{d}^{z}$ & 26,9 & 25,8 & 30,5 & 26,4 & 25,8 & 30,5 & 26,5 & 25,8 & 30,6 & 26,5 & 25,8 & 30,5 \\
\hline $\mathrm{MS} ; \hat{\theta}=0$ & & 33,6 & 33,3 & 37,2 & 33,8 & 33,3 & 37,2 & 33,8 & 33,3 & 37,5 & 33,7 & 33,3 & 37,2 \\
\hline $\mathrm{MS} ; \hat{\theta} \neq 0$ & $\hat{h}_{f}^{2}$ & 2,9 & 3,1 & 3,2 & 2,4 & 2,4 & 2,8 & 2,9 & 3,1 & 3,3 & 2,9 & 3,1 & 2,1 \\
\hline$M S ; \hat{\theta}=0$ & & 4,3 & 3,8 & 9,3 & 3,6 & 2,9 & 8,8 & 4,3 & 3,9 & 9,2 & 4,3 & 3,8 & 8,9 \\
\hline $\mathrm{MS} ; \hat{\theta} \neq 0$ & $\hat{\hat{h}}_{s}^{2}$ & 26,7 & 25,8 & 30,2 & 26,4 & 25,8 & 30,5 & 26,4 & 25,8 & 30,2 & 26,4 & 25,8 & 21,8 \\
\hline $\mathrm{MS} ; \hat{\theta}=0$ & & 33,7 & 33,3 & 37,3 & 33,8 & 33,3 & 37,3 & 33,7 & 33,1 & 36,9 & 33,8 & 33,2 & 37,4 \\
\hline $\mathrm{MS} ; \hat{\theta} \neq 0$ & $\hat{h}_{i}^{2}$ & 19,4 & 19,4 & 22,7 & 19,8 & 19,3 & 22,8 & 19,7 & 19,4 & 22,9 & 19,7 & 19,3 & 20,8 \\
\hline $\mathrm{MS} ; \hat{\theta}=0$ & & 25,0 & 24,9 & 27,9 & 25,4 & 24,9 & 28,0 & 25,3 & 24,9 & 27,9 & 25,3 & 24,9 & 27,9 \\
\hline \multicolumn{14}{|c|}{ E. E. Pedemeiras } \\
\hline $\mathrm{MS} ; \hat{\theta} \neq 0$ & $\hat{\hat{h}}_{d}^{2}$ & 26,4 & 25,9 & 30,5 & 26,4 & 26,0 & 30,4 & 26,4 & 25,8 & 30,4 & 26,4 & 40,0 & 30,4 \\
\hline $\mathrm{MS} ; \hat{\theta}=0$ & & 33,7 & 33,3 & 37,3 & 33,8 & 33,3 & 37,3 & 33,8 & 33,2 & 37,3 & 33,7 & 40,0 & 37,3 \\
\hline $\mathrm{MS} ; \hat{\theta} \neq 0$ & $\hat{\hat{h}}_{f}^{2}$ & 2,6 & 2,7 & 2,9 & 1,8 & 1,1 & 2,4 & 3,3 & 2,5 & 3,0 & 2,4 & 3,1 & 2,8 \\
\hline $\mathrm{MS} ; \hat{\theta}=0$ & & 3,3 & 3,5 & 3,6 & 3,6 & 3,0 & 8,8 & 4,3 & 3,2 & 3,7 & 3,1 & 3,1 & 3,4 \\
\hline $\mathrm{MS} ; \hat{\theta} \neq 0$ & $\hat{h}_{p}^{2}$ & 25,8 & 26,0 & 30,5 & 20,0 & 11,7 & 26,0 & 26,5 & 25,7 & 30,5 & 26,4 & 25,0 & 30,4 \\
\hline $\mathrm{MS} ; \hat{\theta}=0$ & & 33,1 & 33,3 & 37,2 & 33,7 & 33,1 & 37,4 & 33,8 & 33,3 & 37,3 & 33,8 & 50,0 & 37,3 \\
\hline $\mathrm{MS} ; \hat{\theta} \neq 0$ & $\hat{\hat{h}}_{\mathrm{b}}^{2}$ & 26,6 & 26,0 & 30,6 & 25,2 & 17,2 & 31,1 & 26,5 & 25,5 & 30,2 & 27,3 & 0,0 & 30,5 \\
\hline $\mathrm{MS} ; \hat{\boldsymbol{\theta}}=0$ & & 33,9 & 33,2 & 37,5 & 33,8 & 33,3 & 37,2 & 33,6 & 34,0 & 37,1 & 34,5 & 0,0 & 37,1 \\
\hline $\mathrm{MS} ; \hat{\theta} \neq 0$ & $\hat{\hat{h}}_{i}^{2}$ & 19,8 & 19,4 & 22,8 & 18,5 & 16,5 & 21,9 & 19,8 & 19,5 & 22,9 & 19,8 & 16,7 & 22,8 \\
\hline $\mathrm{MS} ; \hat{\theta}=0$ & & 25,3 & 25,0 & 28,0 & 25,3 & 25,0 & 28,0 & 25,3 & 25,0 & 28,0 & 25,3 & 33,3 & 28,0 \\
\hline
\end{tabular}


Tabela 63. Progênies selecionadas e número de plantas selecionadas em cada método de seleção em população de $C$. legalis.

\begin{tabular}{|c|c|c|c|c|c|c|}
\hline \multirow[b]{3}{*}{ Prog } & \multicolumn{6}{|c|}{ População Campinas } \\
\hline & \multicolumn{2}{|c|}{$\begin{array}{c}\text { Indice de seleção Multi- } \\
\text { efeito }\end{array}$} & \multicolumn{2}{|c|}{ Seleção Entre Progênies } & \multicolumn{2}{|c|}{$\begin{array}{l}\text { Seleção Dentro de } \\
\text { Progênies }\end{array}$} \\
\hline & LA & $\mathrm{PE}$ & LA & $\mathrm{PE}$ & LA & $\overline{\mathrm{PE}}$ \\
\hline 1 & 5 & & 1 & & 4 & \\
\hline 2 & 2 & 1 & 2 & 2 & 4 & 4 \\
\hline 3 & 4 & & 3 & & 4 & \\
\hline 4 & 2 & & 4 & 4 & 4 & 4 \\
\hline 5 & 2 & 4 & 5 & 5 & 4 & 4 \\
\hline 6 & & 4 & & 6 & & 4 \\
\hline 7 & & & & & 4 & \\
\hline 8 & 6 & 6 & 8 & 8 & & 4 \\
\hline 9 & & 4 & & 9 & & 4 \\
\hline 10 & & 6 & 10 & 10 & 4 & 4 \\
\hline 11 & 6 & 5 & 11 & 11 & 4 & 4 \\
\hline 12 & & 6 & & 12 & & 4 \\
\hline 13 & 5 & & 13 & & 4 & \\
\hline 14 & 6 & 3 & 14 & 14 & 4 & 4 \\
\hline 15 & & & & & & \\
\hline 16 & & 1 & & & & \\
\hline 17 & 6 & & 17 & & 4 & \\
\hline $\mathrm{n}$ & 44 & 40 & 11 & 10 & 44 & 40 \\
\hline
\end{tabular}

\begin{tabular}{lll}
\hline 18 & 5 & 2 \\
19 & 5 & 2 \\
20 & 6 & 3 \\
21 & 4 & 6 \\
22 & & \\
23 & 1 & 3 \\
24 & 2 & 6 \\
25 & 1 & \\
26 & & 3 \\
27 & 4 & \\
28 & 3 & 2 \\
29 & & 4 \\
30 & 1 & \\
31 & & \\
32 & & 5 \\
33 & & \\
\hline $\mathbf{\pi}$ & 32 & 36
\end{tabular}

\begin{tabular}{cc}
\multicolumn{2}{c}{ População Ibicatu } \\
\hline 18 & 19 \\
19 & 20 \\
20 & 21 \\
21 & 23 \\
& 24 \\
24 & 26 \\
& 28 \\
27 & 29 \\
28 & \\
30 & 32 \\
& \\
\hline 8 & 9
\end{tabular}

\begin{tabular}{ll}
\hline 4 & 4 \\
4 & 4 \\
4 & 4 \\
4 & 4 \\
& 4 \\
4 & 4 \\
& 4 \\
4 & 4 \\
4 & \\
& 4 \\
4 & 4 \\
\hline 32 &
\end{tabular}


Tabela 63. Progênies selecionadas e número de plantas selecionadas em cada método de seleção em população de C. legalis.

\begin{tabular}{|c|c|c|c|c|c|c|}
\hline \multirow[b]{3}{*}{$\begin{array}{c}\text { Prog } \\
34 \\
35\end{array}$} & \multicolumn{6}{|c|}{ População Vassununga } \\
\hline & \multicolumn{2}{|c|}{$\begin{array}{l}\text { Indice de seleção Multi- } \\
\text { efeito }\end{array}$} & \multicolumn{2}{|c|}{ Seleção Entre Progênies } & \multicolumn{2}{|c|}{$\begin{array}{l}\text { Seleção Dentro de } \\
\text { Progênies }\end{array}$} \\
\hline & LA & $\mathrm{PE}$ & LA & $\mathrm{PE}$ & LA & $\mathrm{PE}$ \\
\hline 36 & 6 & 6 & 36 & 36 & 4 & 4 \\
\hline $\begin{array}{l}37 \\
38 \\
39 \\
40\end{array}$ & 5 & 6 & 37 & 37 & 4 & 4 \\
\hline $\begin{array}{l}41 \\
42 \\
43\end{array}$ & 5 & & 41 & & 4 & \\
\hline 44 & & 6 & & 44 & & 4 \\
\hline 45 & 2 & 1 & 45 & 45 & 4 & 4 \\
\hline 46 & 2 & 1 & 46 & & 4 & \\
\hline 47 & 6 & 5 & 47 & 47 & 4 & 4 \\
\hline 48 & & 2 & & 48 & & 4 \\
\hline 49 & & 5 & & 49 & & 4 \\
\hline $\begin{array}{l}50 \\
51\end{array}$ & 2 & & 50 & 50 & 4 & 4 \\
\hline 52 & 4 & 2 & 52 & 52 & 4 & 4 \\
\hline 53 & & 3 & & 53 & & 4 \\
\hline $\begin{array}{l}54 \\
55\end{array}$ & 4 & & 54 & & 4 & \\
\hline$n$ & 36 & 40 & 9 & 10 & 36 & 40 \\
\hline
\end{tabular}

la 17: pop. Campinas; 18 a 33: pop. Ibicatu; 34 a 55: pop. Vassununga. 


\section{REFERÊNCIAS BIBLIOGRÁFICAS}

ALFENAS, S.A. Eletroforese de isoenzimas e proteínas afins: Fundamentos e aplicações em plantas e microrganismos. Viçosa: UFV, 1998. 574 p.

ALLARD, R.W. Princípios do melhoramento genético das plantas. São Paulo: Edgard Blucher, 1971. $381 \mathrm{p}$.

ALVAREZ-BUYLLA, E.R.; GARAY, A.A. Population genetic structure of Cecropia obtusifolia, a tropical pioneer species. Evolution, v. 48, n. 2, p 437-453, 1994.

ASHTON, P.S. An approach to the study of breeding systems, population structure and taxonomy of tropical trees. In: BURLEY, J.; STYLES, B.T. (Ed). Tropical trees: variation, breeding and conservation. London: Academic Press, 1976, Cap. 2, p. 3542.

BAWA, K.S. Breeding systems of tree species for a lowland tropical community. Evolution, v. 28, p. 85-92, 1974.

BAWA, K.S.; PERRY, D.R.; BEACH, J.H. Reproductive biology of tropical lowland rain forest trees. 1. Sexual systems and incompatibility mechanisms. American Journal of Botany, v. 72, n. 3, p 331-45, 1985.

BEIGUELMAN, B. Curso prático de bioestatística. Ribeirão Preto: SBG, 1996. 242 p.

BERG, E.E.; HAMRICK, J.L. Quantification of diversity at allozyme loci. Canadian Journal Forest Research., v. 27, p. 415-424, 1997.

BESSEGA, C.; FERREYRA, L.; JULIO, N.; MONTOYA, S.; SAIDMAN, B.; VILARDI, J. Mating system parameters in species of genus Prosopis (Leguminosae), Hereditas, v. 132, p. 19-27, 2000.

BLADA, I. Diallel crossing in Pinus cembra. III. Anatysis of genetic variation at the nursery stage. Silvae Genetica, v. 48, n. 3/4, p. 179-187, 1999. 
BOSHIER, D.H.; CHASE, M.R.; BAWA, K.S. Population genetic of Cordia alliodora (Boraginaceae), a naotropical tree. 3. Gene flow, neighborhood and population substructure. American Journal of Botany, v. 82, n. 4, p. 484-490, 1995.

BOUVET, J.M.; VIGNERON, P. Variance structure in Eucalyptus hibrid populations. Silvae Genetica, v. 45, n. 2/3, p. 171-177, 1996.

BOYLE, T.J.B.; MORGENSTERN, E.K. Estimation of outcrossing rates in six populations of Black Spruce in central New Brunswick. Silvae Genetica, v. 35 n. 2-3, 102-106, 1986.

BOYLE, T.J.B.; YEH, F.C. Within populations genetics variation and its implications for seletion and breeding. In: MORGENSTEIN, E.K.; BOYLE, T.J.B. (Ed.). Tree Improvement - Progressing Together: Proceedings of the 21 st Meeting of the Canadian Tree Improvement Association. Part 2, N.S. Truro, NS: 17-21, August, 1987. p. 20-42. Forestry Canada, Ottawa, 1988.

BROTSCHOL, J.V.; ROBERDS, J.H.; NAMKOONG, G. Allozyme variation among North Carolina populations of Liriodendron tulipifera L. Silvae Genetica, v. 35, n. 4, p. 131-138, 1986.

BROWN, A.H.D. Genetic characterization of plant mating systems. In: Plant population genetics, breeding and genetic resources. BROWN, A.H.D.; CLEGG, M.T.; KAHILER, A.L.; WEIR, B.S. Sunderland: Sinauer, 1989. Cap. 9, p. 145-162.

BROWN, A.H.D. Isozymes, plant populations genetics structure and genetic conservation. Theorical and Applied Genetics, v. 52, p. 145-157, 1978.

BROWN, A.H.D.; ALLARD, R.W. Estimation of mating systems in open-pollinated maize populations using isozymes polymorphisms. Genetics, n. 66, p. 133-145, 1970.

BROWN, A.H.D.; BARRETT, S.C.H.; MORAN, G.F. Mating system estiamtion in forest trees: Models, methods and meanings. In: Gregorius, H.R. Population genetics in forestry. Berlin: Springer-Verlag, 1985, p. 32-49.

BROWN, A.H.D.; HARDNER, C.M. Sampling the gene pools of forest trees for ex situ conservation. In: Young, A.; Boshier, D; Boyle, T. (Ed.). Forest conservation genetics: Principles and practice. Collinqwood: CSIRO, 2000. p. 185-196. 
BROWN, A.H.D.; MATHESON, A.C.; ELDRIDGE, K.G. Estimation of the mating system of Eucalyptus obliqua L'Hérit. by using allozyme polymorphisms. Australian Journal of Botany, v. 23, p. 931-949, 1975.

BULIUCKAS, V.; EKBERG, I.; ERIKSSON, G.; NORELL, L. Genetic variation among and within populations of four Swedish hardwood species assessed in a nursery trial. Silvae Genetica, v. 48, n. 1, p. 17-25, 1999.

BURCLEY, D.P.; O'MALEY, D.M.; APSIT, V. PRANCE. G.T.; BAWA, K.S. genetics of Brazil nut (Bertholletia excelsa Humb. \& Bonpl.: Lecythidaceae). 1. Genetic variation in natural populations. Theorical and Applied Genetics, v. 76, p. 923-928, 1988.

BURCZYK, B.J. Mating system variation in a Scots Pine clonal seed orchard. Silvae Genetica, v. 47, n. 2/3, p. 155-158, 1998.

CAMPINHOS, E.N.; ROBINSON, I.P.; BERTOLUCCI, F.L.; ALFENAS, A.C. Interspecific hybridization and inbreeding effect in seed from a Eucalyptus grandis $\mathrm{x}$ E. urophylla clonal orchard in Brasil. Genetics and Molecular Biology, v. 21, n. 3, p. $369-374,1998$.

CARVALHO, P.E.R. Espécies florestais brasileiras: recomendações silviculturais, potencialidades e uso de madeira. Brasilia: EMBRAPA, CNPF, 1994, 640 p.

CHANGTRAGOON, S.; FINKELDEY, R. Patterns of genetic variation and characterization of the mating system of Pinus merkusii in Thailand. Forest Genetics, v. 2 , n. 2 , p. $87-97,1995$.

CHARLESWORTH, D.; CHARLESWORTH, B. Inbreeding depression and its evolutionary consequences. Annual Review Ecology and Systematics, v. 18, p. 237$268,1987$.

CHELIAK, W.M.; DANCIK, B.P.; MORGAN, K.; YEH, F.C.H.; STROBECK, C. Temporal variation of the mating system in a natural population of Jack Pine. Genetics, v. 109, p. 569-584, 1985.

CHELIAK, W.M.; PITEL, J.A.; MURRAY, P. Population structure and mating system of white spruce. Canadian Journal Forest Research, v. 15, p. 301-308, 1985. 
CHELIAK, W.M.; PITTEL, J.A. Techniques for starch gel eletrophoresis of enzymes from forest tree species. Information Report, Chalk River. v. 42, p. 1-49, 1984.

CHRISTOPHE, C.; BIROT, Y. Genetic variation within and between populations of Douglas fir. Silvae Genetica, v. 28, n. 5/6, p. 197-206, 1979.

CHUNG, M.G.; CHUNG, J.M.; EPPERSON, B.K. Spatial structure of allozyme polymorphisms whithin populations of Rhus trichocarpa (Anacardiaceae). Silvae Genetica, v. 48, n. 5, p. 223-227, 1998.

CHUNG, M.G.; EPPERSON, B.K. Spatial structure of allozyme polymorphisms in a populations of Eurya japonica (Theaceae). Silvae Genetica, v. 49, n. 1, p. 1-4, 2000.

CLAYTON, J.; TRETIAK, D. Amine-citrate buffers for $\mathrm{pH}$ control in starch gel electrophoresis. Journal Fisheries Research Board Canadian, v. 29, p. 1169-1172, 1972.

CLEGG, M.T. Measuring plant mating systems. Bioscience, v. 30 , n. 12 , p. 814-18, 1980.

CLEGG, M.T., KAHLER, A.L.; ALLARD, R.W. Estimation of Life Cycle Components of Selection in a Experimental Plant Population. Genetics, v. 89, p. 765-92, 1978.

COCKERHAM, C.C. Effects of linkage on the covariances between relatives. Genetics, v. 41 , p. $138-141,1956$.

COCKERHAM, C.C. Estimation of genetic variances. In: HANSON, W.D. \& ROBINSON, H.F. (Ed.). Statistical genetics and plant breeding. Washington: National Academic Science, National Resourse Council, DC. 1963. p. 53-94.

COCKERHAM, C.C. Implications of genetic variances in a hibrid breeding program. Crop Science, v. 9, p. 47-52, 1966.

COCKERHAM, C.C. Inplications of genetic variances in a hibrid breeding program. Crop Science, v. 1, p. 47-52, 1961.

COCKERHAM, C.C. Variance of gene frequencies. Evolution, n. 23, p. 72-84, 1969.

COCKERHAM, C.C.; WEIR, B.S. Covariances of relatives stemming a population undegoing mixed self and random mating. Biometrics, v. 40, p. 157-164, 1984.

COLES, J.F.; FOWLER, D.P. Inbreeding in neighboring trees in two White Spruce populations. Silvae Genetica, v. 25, n. 1, p. 29-34, 1976. 
COMSTOCK, R.E.; ROBINSON, H.F. The components of genetic variances in populations of biparental progenies end their use in estimating the average degree of dominance. Biometrics, v. 4, p. 254-266, 1948.

CORREA, M.P. Dicionário das plantas úteis do Brasil e das exóticas cultivadas. Rio de Janeiro: Imprensa Nacional, 1984. 436p.

COTTERILL, P.P.; DEAN, C.A. VAN WYK, G. Additive and dominance genetic effects in Pinus pinaster, $P$. radiata and $P$. elliotti and some implications for breeding strategy. Silvae Genetica, v. 36, n. 5/6, p. 221-231, 1987.

CROW, J.F. KIMURA, M.A. An introduction to population genetics theory. London: Harper Row, 1970, 591 p.

CROW, J.F. Mutation, mean fitness and genetic load. Oxt Survival Evololution Biology, v. 9 , p. 3-42, 1993.

CRUZ, C.D.; REGAZZI, A.J. Modelos biométricos aplicados ao melhoramento genético. Viçosa: UFV, 1997. 390 p.

DEWEY, S.E.; HEYWOOD, J.S. Spatial genetic structure in a population of $P_{\text {sychotria }}$ nervasa. I. Distribution of genotypes. Evolution, v. 42, p. 834-838, 1988.

DIAS, L.A.S.; KAGEYAMA, P.Y. Variação genética em espécies arbóreas e consequências para o melhoramento florestal. Agrotrópica, v. 3, n. 3, p. 119-27, 1991.

DUDA, L.L.; RESENDE, M.D.V.; CÂNDIDO, H.C.S. Avaliação genética e seleção em Eucalyptus grandis na região de Arapoti - PR. Revista Árvore, v. 21, n. 4, p. 537545, 1997.

DUREL, C. E.; BERTIN, P.; KREMER, A. Relationship between inbreeding depression and inbreeding coefficient in Maritime Pine (Pinus pinaster). Theorical and Applied Genetisc, v. 92, p. 341-350, 1990.

EL-KASSABY, A.; PARKINSON, J.; DEVITT, W.J.B. The effect of crown segment on the mating system in a Douglas-Fir [Pseudotsuga menziessi (Mirb.) Franco] seed orchard. Silvae Genetica, v. 35, n. 4, p. 149-155, 1986. 
EL-KASSABY, A.; RUSSEL, J.; RITLAND, K. Mixed mating in an experimental population of wester Red Cedar, Thuja plicata. Journal of Heredity, v. 85, p. 227$231,1994$.

EL-KASSABY, A.; YEH, F.C.; SZTKLAI, O. estimation of the outcrossing rate of Douglas-fir [(Pseudotsuga menziesii (Mirb.) Franco], using allozime polymorfisms. Silvae Genetica, v. 30, n. 6, p. 182-184, 1981.

EL-KASSABY.Y. A.; MEAGHER, M.D.; PARKINSON, J.; PORTLOCK, F.T. Allozyme inherritance, heterozygosity and outcrossing rate among Pinus monticola near Ladysmith, British Colunbia. Heredity, v. 58, p. 173-181, 1987.

ELDRIDGE, K.; DAVIDSON, J.; HARWOOD, C.; VAN WYK GERRIT. Eucalypt domestication and breeding. Oxford: Clarendon Press, 1993, 288.

ELDRIDGE, K.G. Breeding system of Eucalyptus regnans. In: IUFRO PROCEEDING MEETING. Varparanta: IUFRO, 1970. p. 1-12.

ELDRIDGE, K.G. Genetic improvement of Eucalyptus. Silvae Genetica, v. 27. p. 205$209,1978$.

ELLSTRAND, N.; ELAM, D.R. Population genetic consequences of small population size: Implications for plant conservation. Annual Review of Ecology and Systematics, v. 24, p. 217-242, 1993.

EPPERSON, B.K. Spatial patterns of genetic variation within plant populations. In: BROWN, A.H.D.; CLEGG, M.T.; KAHLER, A.L.; WEIR, B.S. (Ed.): Plant population genetics, breeding and genetic resources. Sunderland: Sinauer, 1990, p. 229-253.

ERICSSON, T. The effect of pedigree error by misidentification of individual trees on genetic evaluation of a full-sib experiment. Silvae Genetica, v. 48 , n. 5 , p. 239-242, 1999.

ETTORI, L.C.; SIQUEIRA, A.C.M.F.; NOGUEIRA, J.C.B.; FERREIRA, A.B.; ZANATTO, A.C.S. Conservação ex situ dos recursos genéticos do Ipê-amarelo (Tabebuia vellosoi Tol.) através de testes de procedências e progênies. Revista do Instituto Florestal, v. 7, n. 2, p. 157-168, 1995. 
ETTORI, L.C.; SIQUEIRA, A.C.M.F.; SATO, A.S.; CAMPOS, O.R. Variabilidade genética em populações de Ipé-roxo - Tabebuia heptaphylla (Vell.) Tol. - para conservação ex situ. Revista do Instituto Florestal, v. 8, n. 1, p. 61-70, 1996.

ETTORI, L.C.; SIQUEIRA, A.C.M.F.; ZANATTO, A.C.S.; BOAS, O.V. Variabilidade genética em duas populações de Cordia trichotoma. Revista do Instituto Florestal, v. 11, n. 2, p. 179-187, 1999.

FALCONER, D.S.; MACKAY, T.F.C. Introduction to quantitative genetics. England: Longman Group, 1997. 463 p.

FAO. Panel of experts on forest gene resources. Rome, 1996, 64 p.

FARRIS, M.A.; MITTON, J.B. Population density, outcrossing rate and heterozygote superiority in Ponderosa Pine. Evolution, v. 38, p. 1151-1154, 1985.

FEDEROFF, A.A. The structure of the tropical rain forest and speciation in the humid tropics. Journal of Ecology, v. 96, p. 9-20, 1966.

FERREIRA, M.A.J.F. Sistema reprodutivo e potencial para o melhoramento genético de uma população de melância Citrullus lanatus (Thunb.) Matsum. \& Nakai. Piracicaba, 2000. 148 p. Tese (Doutorado) - Escola Superior de Agricultura "Luiz de Queiroz", Universidade de São Paulo.

FLORENCE, R.G. Variation in Backbutt. Australian Forest, v. 33, p. 83-93, 1969.

FRANKEL, O.H.; SOULÉ, M.S. Conservation and evolution. Cambridge, Cambridge University Press, 1981. 327 p.

FRANKELL, O.H. Philosophy and strategy of genetic conservation in plants. In: THIRT WORLD CONSULATION ON FOREST TREE BREEDING. Camberra: Documennts, v. 1, p. 611, 1977.

FRANKLIN, E.C. Adjustment of heritabilities estimated by correlation coefficients for typical forest tree breeding experiments. Silvae Genetica, v. 23 , n. 6, p. 176-180, 1974.

FRIEDMAN, S.T.; ADAMS, W.T. Leves os outcrossing in two Loblolly Pine seed orchards. Silvae Genetica, v. 34, p. 157-161, 1985. 
FRIES, A.; ERICSSON, T. Genetic parameters in diallel-crossed Scots Pine favor heartwood formation breeding objectives. Canadian Journal of Forest Resource, v. 28, p. 937-941, 1998.

FRIPP, Y.J. Allozime variation and mating system in two population of Eucalyptus kitsoniana (Leuhm) Maiden. Autralian Journal of Forestry Research, v. 13, p. 110,1982

FUJSHIMA, T.; FREDEEN, H.T. General formulae for estimating heritability in a population with related parents. Canadian Journal of Genetic and Cytologty, v. 14, p. 549-557, 1972.

FURNIES, G.R.; ADAMS, W.T. Model of reproduction in higher plants. Botanical Review, v. 23, p. 135-233, 1986.

FUTUYMA, D.J. Biologia evolutiva. Ribeirão Preto: SBG, 1992, 646 p.

GANDARA, F.B. Diversidade genética, taxa de cruzamento, e estrutura espacial dos genótipos em uma população de Cedrela fissilis Vell. (Meliaceae). Campinas, 1996, 69 p. Dissertação (Mestrado) - Universidade de Campinas.

GEBUREK, Th. Some results of inbreeding depression in Serbian Spruce [Picea omorica (Panc.) Purk.]. Silvae Genetica, v. 35, p. 169-172, 1986.

GHAI, G.L. Covariances among relatives in populations uner mixed self-fetilization and random mating. Biometrics, v. 38, p. 87-92, 1982.

GIANNOTTI, E.; TIMONI, J.L.; MARIANO, G.; COELHO, L.C.C.; FONTES, M.A.; KAGEYAMA, P.Y. Variação genética entre procedências e progênies de Araucaria angustifolia (Bert.) O. KTZE. In: CONGRESSO NACIONAL SOBRE ESSÊNCIAS NATTVAS. Campos do Jordão, 1982. Anais. Silvicultura em São Paulo, v. 16A: p. 970-975. (Edição especial).

GIBSON, J.P.; NATHANIEL, T.; WRIGHT, W. Mating system of Ocotea tenera (Lauraceae), a gynodioecious tropical tree. American Journal of Botany, v. 83, n. 7, p. $890-894,1996$. 
GIUDICE NETO, J.D. Estrutura genética por isoezimas em populações naturais de Jacarandá Paulista (Machaerium villosum Vog.). Piracicaba, 1999. 128 p. Dissertação (Mestrado) - Escola Superior de Agricultura "Luiz de Queiros", Universidade de São Paulo.

GRIFFIN, A.R.; COTTERIL, P.P. Genetic variation in growth of outcrossed, selfed and open-pollinated progenies of Eucalyptus regnans end some implications for breeding strategy. Silvae Genetica. v. 37, p. 124-131, 1988.

GRIFFTTH, J.J. Economia da conservação in situ de recursos genéticos florestais. IPEF, v. 35, p. $85-92,1987$.

GURGEL GARRIDO, L.M.A.; SIQUEIRA, A.C.M.F.; CRUZ, S.F.; ROMANELLI, R.C.; ETTORI, L.C.; CRESTANA, C.S.M; SILVA, A.A.; MORAIS, E.; ZANATTO, A.C.S.; SATO, A.S. Programa de melhoramento genético florestal do Instituto Florestal de São Paulo (Acervo). IF Série Registros, v. 18, p. 1-53, 1997.

GURIES,R.P.; LEDIG, 1982, F.T. Genetic diversity and population structure in picth pine (Pinus rigida) Mill.). Evolution, v. 36, p. 387-402, 1982.

HALL, P.; ORRELL, L.C.; BAWA, K.S. Genetic diversity and mating system in a tropical tree, Carapa guianensis (Meliaceae). American Journal of Botany, v. 81, n. 9, p. 1104-1111, 1994.

HALL, P.; WALKER, S.; BAWA, K.S. Effect of forest fragmentation on genetic diversity and mating system in a tropical tree, Pithecellobium elegans. Conservatiom Biology, v. 10, n. 3, p. 757-768, 1995.

HALLAUER, A.R.; MIRANDA FILHO, J.B. Quantitative genetics in maize breeding. Ames: Iowa State University Press, 1988. 469p.

HAMRICK, J. L. Allozyme diversity of natural stands versus seed orchard Loblolly Pine. In: MEETING AND ACTIVTTY REPORTS OF THE CANADIAN TREE IMPROVEMENT ASSOCIATION. Ottawa: 1991. Ottawa: UBC, p. 19-40.

HAMRICK, J.L.; SCHNABEL, A. Understanding the genetic structure of plant populations: Some old problems and a new approach. In: GREGORIOS, H.R. (Ed.). Lecture notes in biomathematics: populations genetics in forestry. Berlin: Springer Verlag, 1985. p 50-70. 
HAMRICK, J.L. Gene flow and distribution of genetic variation in planta populations. In: URBANSKA, K. (Ed.). Differentiation patterns in higher plants. New York: Academic Press, 1987. p.53-76.

HAMRICK, J.L. Isozymes and analysis of genetic structure in plant populations. In: SOLTIS, D.E.; SOLTIS, P. (Ed.), Isozymes and the analysis of genetic structure in plant populations. New York: Chapman and Hall, 1989. p. 87-105.

HAMRICK, J.L. The distribution of genetic variation within and among natural plant population. In: SCHONE-WALD-COX, C.M.; CHAMBERS, S.H.; MacBYDE, B.; THOMAS, L. Genetics and conservation. Menlo Park: Benjamin Cummings, 1983. p. 335-348.

HAMRICK, J.L. Variation and selection in western montane species II. Variation withing and between populations of White Fron an elevation transect. Theorical and Applied Genetic, v. 47, p. 27-34, 1976.

HAMRICK, J.L.; GODT, M.J.W. Allozyme diversity in plant species. In: BROWN, A.H.D.; ClEGG, M.T.; KAHLER, A.L.; WEIR, B.S. (Ed.) Plant population genetics, breeding and genetic resources. Sunderland: Sinauer, 1990. p. 43-63.

HAMRICK, J.L.; LIBBY, W.J. Variation and selection in western montane species. I. White Fir. Silvae Genetica. v. 21, p. 29-35, 1972.

HAMRICK, J.L.; LINHART, Y.B.; MITTON, J.B. Relationships between life history characteristc and eletrophoretically detectable genetic variation in plants. Annual Review Ecolology and Systematics, v. 10, p.173-200, 1979.

HAMRICK, J.L.; LOVELESS, M.D. The influence of seed dispersal mechanisms on the genetic structure of plant populations. In: ESTRADA, A.; FLEMING, T.H. (Ed.) Frugivores and seed dispersal. Athens: Junk Publishers, 1986, cap. 17, p. 124-145.

HAPPER, S.D.; MORAN, G.F. Bird pollination and the mating system of Eucalyptus stoatei. Australian Journal of Botany, v. 29, p. 626-638, 1982.

HARDNER, C. M.; POTTS, B. M. Inbreeding depression and changes in variation after selfing in Eucalyptus globulus ssp. globulus. Silvae Genetica. v. 44, n. 1, p. 46-54, 1995. 
HARDNER, C. M.; POTTS, B. M. Postdispersal selection following mixed mating in Eucalyptus regnans. Evolution, v. 51, n. 1, p. 103-111, 1997.

HARRTT, M. M. Ecology and genetic variation of four hardwoods os Brazil's atlantic forest region. Raleigh, 1991, $204 \mathrm{p}$. Thesis $(\mathrm{PhD})$ - University of North Caroline.

HINKELMANN, K. Estimation of heritability from experiments with related dams. Biometrics, v. 25, p. 755-766, 1969.

HOUSE, A.P.N.; BELL, J.C. Genetic diversity, mating system and systematic relationships in two Red Mahoganies, Eucalyptus pellita and E. scias. Australian Journal of Botany, v. 44, p. 157-174, 1996.

HOUSE, A.P.N.; BELL, J.C. Isozyme variation and mating system in Eucalyptus urophilla S.T. Blake. Silvae Genetica, v. 43, p. 167-176, 1994.

HUDGSON, L.M. Some aspects of flowering and reproductive behaviour in Eucalyptus grandis (Hill) Maiden at J.D.M. Keest Forest Research Station. South Africa Forest Journal, v. 99, p. 53-58, 1976.

HUSBAND, B.C.; SCHEMESKE, D.W. Evolution of the magnitude and timing of inbreeding depresion in plants. Evolution, v. 50, n. 1, p. 54-70, 1996.

ITOMAN, M.K.; SIQUEIRA, A.C.M.F.; CAVASSAN, O. Descrição de quinze espécies arbóreas de mata mesófila do Estado de São Paulo ameaçadas de extinção. Bauru, Salusvita, v. 11, n. 1, p. 1-38, 1992.

JAIN, S.K. Estimation of outcrossing rates: Some alternative procedures. Crop Science, v. 19, p. $23-26,1979$

JOHNSTON, M.; SCHOEN, D.L. On the measurement of inbreeding depression. Evolution, v. 48, n. 5, p 1735-1741, 1994.

KAGEYAMA, P.Y. Conservação in situ dos recursos genéticos de plantas. IPEF, v. 35, p. 7-48, 1987.

KAGEYAMA, P.Y. Variação genética em progênies de uma população de Eucalyptus grandis (Hill) ex Maiden. Piracicaba, 1980. 125 p. Tese (Doutorado) - Escola Superior de Agricultura "Luiz de Queiroz", Universidade de São Paulo.

KÄRKKÄINEN, K.; KOSKI, V.; SAVOLAINEN, O. Geographical variation in the inbreeding depression of scots pine. Evolution, v. 50, n. 1, p. 111-119, 1996. 
KÄRKKÄINEN, K.; SAVOLAINEN, O. The degree of earty inbreeding depression determines the selfing rate at the seed stage: Model and results from Pinus sylvestris (Scots pine). Heredity, v. 71, p. 160-166, 1993.

KAWAGUICI, C.B. Variação genética em três grupos de indivíduos (adultos, jovens e plântulas) de Calophyllum bresiliense Camb. (Clusia Ceae), em mata de galeria. Piracicaba, 1999. 98 p. Dissertação (Mestrado) - Escola Superior de Agricultura "Luiz de Queiroz", Universidade de São Paulo.

KEHLET, J.; ROULUND, H. Genetic parameters for spiral grain in two 18-year-old progeny trials with Sitka Spruce in Denmark. Canadian Journal Forest Research, v. 28, p. 92-931, 1998.

KEMPTHORNE, O. An introduction to genetic statistics. The Iowa University Press, Ames: 1957. 545p.

KEMPTHORNE, O. Correlation between relatives in a random mating population. Proceedings of Royal Society, v. 143, p. 103-113, 1954.

KENNINGTON, W.J.; JAMES, S.H. The effect of small population size on the mating system of rare clonal mallee, Eucalyptus argutifolia (Myrtaceae). Heredity, v. 78, p. 252-260, 1997.

KEPHART, S.R. Starch gel eletrophoresis of plant isozymes: A comparative analysis of techniques. American Journal of Botany, v. 77, n. 5, p. 693-712, 1990.

KERTADIKARA, A.W.S.; PRAT, D. Genetic structure and mating system in Teak (Tectona grandis L. F.) provenances. Silvae Genetica, v. 44, n. 2-3, p. 104-110, 1996.

KEYS, R.N.; SMITH, S.E. Mating system parameters and population genetic structure in pioneer populations of Prosopis velutina (Leguminosae), American Journal of Botany, v. 81, n. 8, p. 1013-1020, 1994

KHALIL, M.A. Genetics of wood characteres of black spruce [Picea mariana (Mill.) B.S.P.] in Newfoundland, Canada. Silvae Genetica, v. 34, n. 6, p. 221-230, 1985.

KHASA, P.D.; CHELIAK, W.M.; BOUSQUET, J. Mating system of Racosperma auriculiforme in a seed production area in Zaire. Canadian Journal of Botany, v. 71, p. $779-785,1993$ 
KJAER, E.D.; SUANGTHO, V. Outcrossing rate of Teak [Tectona grandis (L.)]. Silvae Genetica, v. 44, n. 4, p. 175-177, 1995.

KNOWLES, P.G.R.; FURNIER, M.A.; ALEKSUIK, M.A.; PERRY, D.J. Significant levels of self-fertilization in natural populations of tamark. Canadian Journal of Botany, v. 65, p. 1087-1091, 1987.

KNOWLES, P.G.R.; PERRY, D.J.; FOSTER, H.A. Spatial genetic structure in two Tamarack [Larix laricina (Du Roi) K. Koch] populations with differing establishiment histories. Evolution, v. 46, n. 2, p. 572-576, 1992.

KOELEWIJN, H.P. Effects of different levels of inbreeding on progeny fitness in Plantago coronopus. Evolution, v. 52, n. 3, p. 692-702, 1998.

KOELEWIJN, H.P.; KOSKI, V.; SAVOLAINEN, O. Magnitude and timing of inbreeding depression in Scots Pine (Pinus sylvestris L.) Evolution, v. 53, n. 3, p. 758-768, 1999.

KRIEBEL, H.B.; NAMKOONG, G. \& USANIS, R.A. Analysis of genetic variation in 1, 2-, and 3-year old Eastern White Pine in incomplete diallel cross experiments. Silvae Genetica, v. 19, p. 44-48, 1969.

KRUG, C.A.; ALVES, A.S. Eucalyptus improvment. Journal of Heredity, v. 40, p. 133-149, 1949.

LANDE, R. Genetic and demography in biological conservation. Science, v. 241, p. 1455-1460, 1988.

LANDE, R.; SCHEMESKE, D.W. The evolution of seft-fertilization and inbreeding depression in plants. I Genetic models. Evolution, v. 39, n.1, p. 24-40, 1985.

LANDE, R.; SCHEMESKE, D.W.; SCHULTZ, S.T. High inbreeding depression, selective interference among loci, and the threshold selfing rate for purging recessive lethal mutations. Evolution, v. 48, n. 4, 965-978, 1994.

LATTA, R.; RITLAND, K. The relationship between inbreeding depression and prior inbreeding among populations of four Mimulus taxa. Evolution, v. 48, n. 3, p. 806$817,1994$.

LEDIG, F.T. An analysis of methods for the trees from wild stands. Forest Science, v. 20, p. $2-16,1974$. 
LEONARDECZ NETO, E. Variação genética e métodos de seleção em progênies sulafricanas de Pinus patula (Schiede \& Deppe).Curitiba, 1998. 71 p. Dissertação (Mestrado), - Universidade Federal de Curitiba.

LEPSCH-CUNHA, N. Variabilidade genética intrapopulacional de duas espécies de baixa densidade na Amazônia Central: Couratari multiflora (J.E. Smith) Eyma e Couratari guianensis Aublet. Item 1. de Resultados da Dissertação "Estrutura Genética e Fenologia de Espécies Raras de Couratari spp. (Lecythidaceae) na Amazônia Central". Piracicaba, 1996. 121p. Dissertação (Mestrado) - Escola Superior de Agricultura "Luiz de Queiroz", Universidade de São Paulo.

LEWIS, P.0; ZAYKIN, D. GDA - Genetic date analysis: version 1.0(d12) for Windows. Albuquerque: The University of New Mexico, 1999, 39 p.

LEWONTIN, R.C. The genetic basis of evolutionary change. New York: Columbia University Press, 1974. 458p.

LI, C.C.; HORVITZ, D.G. Some methods of estimating the inbreeding coefficient. American Journal of Human Genetics, v. 5, p. 107-117, 1953.

LI, P.; BEAULIEU, J.; CORRIVEAU, A. \& BOUSQUET, J. Genetic variation in juvenile growth and phenology in a White Spruce provenance-progeny test. Silvae Genetica, v. 42, n. 1, p. 52-60, 1993.

LIBBY, W.J. Closing remarks and summary. In: IUFRO JOINT MEETING ON ADVANCEDGERATON BREEDING, PROCEEDINGS. Bordeaux: IUFRO, 1976. p. 181-188.

LIBBY, W.J.; McCUTCHAN, B.G.; MILLAR, C.I. Inbreeding depression in selfs of Redwood. Silvae Genetica, v. 30, p. 15-25, 1981.

LIENGSIRI, C.; BOYLE, T.J.B.; YEH, F.C. Mating system in Pterocarpus Macrocarpus Kurz. in Thailand. The Journal of Heredity, v. 89, n. 3, p. 216-221, 1998.

LIENGSIRI, C.; YEH, F.C.; BOYLE, T.J.B. Isozyme analysis of a tropical forest tree, Pterocarpus Macrocarpus Kurz. in Thailand. Forest Ecology and Management, v. 74, p. 13-22, 1995.

LINDGREN, D.; MULLIN, T.J. Balancing gain and relatedness in selection. Silvae Genetica, v. 46, n. 2/3, p. 124-129, 1997. 
LLERAS, E. Conservação de recursos genéticos florestais. In: CONGRESSO NACIONAL SOBRE ESSÊNCIAS NATTVAS: CONSERVAÇÃO E BIODIVERSIDADE. 2, São Paulo, 1992, Anais. Revista do Instituto Florestal de São Paulo, São Paulo, v. 4, p. 1179-1184, 1992.

LOISELLE, B.A.; SORK, V.L.; NASON, J.; GRAHAM, C. Spatial genetic structure of a tropical understory shrub, Psychotria officinalis (Rubiaceae). American Journal of Botany, v. 82, n. 11, p. 1420-1425, 1995.

LOVELESS, M.D.; HAMRICK, J.L. Distribuicion de la variacion en espécies de arboles tropicales. Revista Biologia Tropicales, v. 35, n. 1, p. 165-75, 1987.

LOVELESS, M.D.; HAMRICK, J.L. Ecological determinants of genetic structure in plant populations. Annual Review of Ecology and Systematics, v. 15, p. 65-95, 1984.

MAINIERI, C. Madeiras brasileiras: Características gerais, zonas de maior ocorrência, dados botânicos e usos. São Paulo: Secretara da Agricultura do Estado de São Paulo. 1970, 109 p.

MALTEZ, H.M. Estrutura genética de Aspidosperma polyneuron Muell. Arg. Apocynaceae (Peroba Rosa) em uma floresta estacional semidecidual no Estado de São Paulo. Campinas, 1997. 132 p. Dissertação (Mestrado) - Universidade de Campinas.

MATHER, W.B. Princípios de genética quantitativa. Ribeirão Preto: SBG, 1994. 137 p.

MATHESON, A.C.; BELL, J.C.; BARNES, R.D. Breeding systems and genetic structure in some central american pine populations. Silvae Genetica, v. 38 , n. 3/4, p. 107-112, 1989.

MATHESON, A.C.; WHITE, T.L.; POWEL, G.R. Effects of inbreeding on growth, sten form and rust resistence in Pinus elliottii. Silvae Genetica, v. 44, n. 1, p. 37-46, 1995. MILLAR, M.A.; BYRNE, M.; COATES, D.J.; STUKELY, M.J.C.; McCOM, J.A. Matng system studies in jarrah, Eucalyptus marginata (Myrtaceae). Australian Journal of Botany, v. 48, p. 475-479, 2000.

MTTTON, J.B. Physiological and demographic variaton associated with allozime variation. In: Isozymes in plant biology. London: Chapman and Hall,1989. cap. 3, p. 127-145. 
MTTTON, J.B.; LATTA, R.G.; REHFELDT, G.E. The pattern of inbreeding in Washoe Pine and survival of inbred progeny under optional environmental condictions. Silvae Genetica, v. 46, n. 4, p. 215-219, 1997.

MITTON, J.B.; LINHART, Y.B.; DAVIS, M.L.; STURGEON, K.B. Estimation of outcrossing in Ponderos pine, Pinus ponderosa Laws., from patterns segregation of protein polymorfisms and from frequencies of albino seedlings. Silvae Genetica, v. 30, n. 3-4, p. 117-121, 1981.

MITTON, J.B.; LINHART, Y.B.; HAMRICK, J.L.; BACKERMAN, J.S. Observation on the genetic structure and mating system of Ponderosa Pine in the colorado front range. Theorical and Applied Genetics, v. 51, p. 5-13, 1977.

MORAES, M.L.T. Variabilidade genéica por isoenzimas e caracteres quantitativos em duas populações naturais de aroeira Myracrodruon urundeuva F.F. \& M.F. Allemão Anacardiaceae (Syn: Astronium urundeuva (Fr. Allemão) Engler. Piracicaba, 1993. 139 p. Tese (Doutorado) - Escola Superior de Agricultura "Luiz de Queiroz", Universidade de São Paulo.

MORAES, P.L.R. Estrutura genética de populações de Cryptocarya moschata Nees \& Martius ex Nees (Lauraceae). Rio Claro, 1997. 190 p. Tese (Doutorado) Universidade Estadual Paulista "Júlio de Mesquita Filho"

MORAN, G.F.; BELL, J.C.; GRIFFIN, A.R. Reduction in levels of inbreeding in a seed orchard of Eucalyptus regnans F. Muell. compared with natural populations. Silvae Genetica, v. 38, n. 1, p. 32-36, 1989.

MORAN, G.F.; BROWN, A..H.D. Temporal heterogenity of outcrossing rates in Alpine Ash (Eucalyptus delegatensis R.T. Bak.). Theorical and Applied Genetics, n. 57, p. 101-105, 1980.

MORAN, G.F.; MUONA, O.; BELL, J.C. Acacia mangium: A tropical forest tree of the coastal lowlands with low genetic diversity. Evolution, v. 43, n. 1, p. 231-235, 1989.

MORAN, G.F.; MUONA, O.; BELL, J.C. Breeding systems and genetic diversity in Acacia auriculiformis and A. crassicarpa. Biotropica, v. 21, n. 3, p. 250-256, 1989. 
MORAN, G.F.; THOMSON, L.A.J., GRANT, J.; BELL, J.C. Distribution of genetic variation within two dry-zone Acacia species and implications for their genetic improvement. In: HOUSE, A.P.N.; HARWOOD, C.E. (Ed.). Australian dry-zone acacias for human food.. Melbourne: CSIRO, 1991. p. 74-81.

MORGANTE, M.; VENDRAMIN, ROSSI, P.; OLIVIERI, A.M. Selection against inbreds in early life-cycle phases in Pinus leucodermis Ant. Heredity, v. 70, p. 622$627,1993$.

MORI, E.S. Estrutura genética de populações narurais de canafístula Peltophorum dubium (Spreng.) Taub. Botucatu, 2000, 145 p. Tese (Livre Docência) - Universidade do Estadual Paulista "Júlio de Mesquita Filho".

MUONA, O.; MORAN, G.F.; BELL, J.C. Hierarchical patterns of correlated mating in Acacia melanoxylon. Genetics, v. 127, p. 619-626, 1991.

MUONA, O; YAZDANI, R.; RUDIN, D. Genetic change between life stages in Pinus sylvestris: allizyme variation in seeds and planted seedlings. Silvae Genetica, v. $36, \mathrm{n}$. 1, p. 39-41, 1987

MURAWSKI, D. A.; HAMRICK, J.L. The mating system of Cavanillesia platanifolia under extremes of flowering-tree density: a test of predictions. Biotropica, v. 24, n. 1, 1992. p. $99-101$.

MURAWSKI, D.A. Reproductive biology and genetics of tropical trees from canopy perpective. In: LOWMAN, M.D.; NADKARNI, N.M. (Ed.). Forest canopies. New York, Academic Press, 1995. p. 457-493.

MURAWSKI, D.A.; BAWA, K.S. Genetic structure and mating system of Stemonoporus oblongifolius (Dipterocarpaceae). Americam Journal of Botany, v. 81, n. 2, p. 155$160,1994$.

MURAWSKI, D.A.; DAYANANDAN, B.; BAWA, K.S. Outcrossing rates of two endemic Shorea species from Sri Lankan tropical rain forest. Biotropica, v. 26, n. 1, p. 23-29, 1994.

MURAWSKI, D.A.; HAMRICK, J.L. Mating system and phenology of Ceiba pentandra (Bombacaceae) in Central Panama. Journal of Heredity, v. 83, n. 6, p. 401-404, 1992. 
MURAWSKI, D.A.; HAMRICK, J.L. The effect of the density of flowering individuals on the mating systems of nine tropical tree species. Heredity, v. 67, p. 167-174, 1991. MURAWSKI, D.A.; HAMRICK, J.L.; HUBBELL, S.P. FOSTER, R.B. Mating system of two Bombacaceous trees of a neotropical moist forest. Oecologia, v. 82, p. 501$506,1990$.

NAMKOONG, G. Imbreed effects on estimation of genetic additive variance. Forest Science, v. 12, p. 8-13, 1966.

NAMKOONG, G. Introduction to quantitative genetics in forestry. Washington: Forest Service, 1979. 342 p. (Technical Bulletin No 1588)

NEALE, D.B.; ADAMS, W.T. The mating system in natural and shelterwood stands of Douglas-fir. Theorical and Apllied Genetics, v. 71, p. 201-207, 1985.

NEI, M. Analysis of gene diversity in subdivided populations. Proceeding National Academy Science. USA, v. 70, n. 12, p. 3321-3323, 1973.

NEI, M. $F$-statistics and analysis of gene diversity in subdividid populations. Annals of Human Genetics, v. 41, p. 225-233, 1977.

NOGUEIRA, J.C.B. Reflorestamento heterogêneo com essências indígenas. Boletim Técnico do IF, v. 24, p. 1-17, 1977.

NOGUEIRA, J.C.B.; SIQUEIRA, A.C.M.F.; ZANATTO, A.C.S. Teste de progênies e procedências do pau d"alho Gallesia gorarema Vell. Moq. Boletim Técnico do IF, v. $40 \mathrm{~A}$, p. $344-356,1986$.

O'MALLEY, D.M.; BAWA, K.S. Mating system of a tropical rain forest tree species. American Journal of Botany, v. 74, n. 8, p. 1143-1149, 1987.

O'MALLEY, D.M.; BUCKLEY, D.P.; PRANCE, G.T.; BAWA, K.S. Genetic of Brazil nut (Bertholletia excelsa Humb. \& Bonpl.: Lecythidaceae). 2. Mating system. Theorical and Applied Genetic, v. 76, p. 929-932, 1988.

OLIVEIRA, A.F. Estrutura genética de populações naturais de Copaifera langsdorffii Desf. a partir de isoenzimas. Lavras, 2000. 115 P. Dissertação (Mestrado) Universidade Federal de Lavras.

OWNNO, F. Genetic divergence in selected populations of Loblolly pine. Silvae Genetica, v. 26, n. $2-3$, p. $64-66,1977$. 
PAIVA, J.R. Variabilidade isoenzimática em populações naturais de seringueira [Hevea brasiliensis (Willd) ex Adr. de Juss.] Müell. Arg. Piracicaba, 1992. 144 p. Tese (Doutorado) - Escola Superior de Agricultura "Luiz de Queiroz", Universidade de São Paulo.

PÉREZ-NASSER, N.; EGUIARTE, L.; PIÑERO, D. Mating system and genetic structure of the Disthylous tropical tree Psychotria faxlucens (Rubiaceae). American Journal of Botany, v. 80, n. 1, p. 45-52, 1993.

PERREIRA, M.B. Estimação de componentes da variância genotípica em populações parcialmente autógamas. In: ENCONTRO SOBRE TEMAS DE GENÉTICA E MeLhoramento. 14., Piracicaba, 1997. Anais. ESALQ/USP, 1997. pag. 47-58, PERRY, D.J.; DANCIK, B.P. Mating system dynamics of Lodge-pole Pine in Alberta, Canada. Silvae Genetica, Frankfurt, v. 35, n. 5/6, p. 190-195, 1986.

PERRY, D.J.; KNOWLES, P. Spatial genetic structure within three Sugar Maple (Acer saccharun Marsh.) stands. Heredity, v. 66: p. 137-142, 1991.

PETERS, G.B.; LONIE, J.S.; MORAN, G.F. The breeding system, genetic diversity and pollen sterilily in Eucalyptzs pulverulenta, a rate species with small disjunct populations. Australian Journal of Botany, v. 38: p. 559-570, 1990.

PHILLIPS, M.A.; BROWN, A.H.D. Mating system and hybridity in Eucalyptus pauciflora. Australian Journal Biology Science, v. 30: p. 337-344, 1976.

PIRES, I.E. Eficiência da seleção combinada no melhoramento genético de Eucalyptus spp. UFV, Viçosa, MG, 116 p., 1996. (Tese de doutorado)

REHFELDT, G.E. Systematics and genetic structure of Washoe Pine: Applications in Conservation genetics. Silvae Genetica, Frankfurt, v. 48(3/4): p. 167-173, 1999.

REIS, M.S. Distribuição e dinâmica da variabilidade genética em populações naturais de palmiteiro (Euterpe edulis M.). ESALQ/USP, Piracicaba, 1996. 210 p, Tese (Doutorado) - Escola Superior de Agricultura "Luiz de Queiroz", Universidade de São Paulo. 
RESENDE, M.D.V. Correções nas expressões do progresso genético com seleção em função da amostragem finita dentro de famílias e populações e implicações no melhoramento florestal. Boletin Pesquisa Florestal, Colombo, PR, n. 22/23: p. 6177, 1991.

RESENDE, M.D.V.; ARAÚJO, A.J.; SAMPAIO, P.T.B.; WIECHETECK, M.S.S. Acurácia seletiva, intervalos de confiança e variâncias de ganho genéticos associados a 22 métodos de seleção em Pinus caribaea var. hondurensis. Revista Floresta, Colombo, PR, n. 24(1/2): p. 35-45, 1995.

RESENDE, M.D.V.; HIGA, A.R. Estimação de valores genéticos no melhoramento de Eucalyptus: Seleção em um carácter com base em informações do indivíduo e seus parentes. Boletim de Pesquisa Florestal, Colombo, PR, n. 28/29: p. 11-36, 1994.

RESENDE, M.D.V.; HIGA, A.R. Maximização da eficiência de seleção em testes de progênies de Eucalyptus através da utilização de todos os efeitos do modelo matemático. Boletim de Pesquisa Florestal, Colombo, PR, n. 28/29: p. 37-55, 1994. RESENDE, M.D.V.; HIGA, A.R.; HELLER, J.B.; STEIN, P.P. Parâmetros genéticos e interação genótipo $\mathrm{x}$ ambiente em testes de procedências e progênies de acácia-negra (Acacia mearnsii). Boletim de Pesquisa Florestal, n.. 24/25, p. 55-65, 1992.

RITLAND, K. Correlated matings in the partial selfer Mimulus guttatus. Evolution, v. 43 , n. 4: p. 848-859, 1989.

RITLAND, $\mathrm{K}$. Inferences about inbreeding depression based on changges of the inbreeding coefficient. Evolution, v. 44: p. 1230-1241, 1990.

RITLAND, K. Infering the genetic basis of inbreeding depression in plants. Genome, v. 39: p. 1-8, 1996.

RITLAND, K. Multilocus mating system program MLTR. Version 1.1. University of Toronto, Canada. 1997. (Não Publicado).

RITLAND, K. Series of FORTRAN Computer Programs for Estimating Plant Mating Systems. Journal of Heredity, v. 81: p. 235-237, $1990 \mathrm{~b}$.

RITLAND, K.; JAIN, S. A model for the estimation of outcrossing rate and gene frequencies using independent loci. Heredity, v. 47: p. 35-52, 1981. 
RÜTHER, B.; HAMRICK, J.L.; WOOD, B.W. Outcrossing rates and relateness estimates in Pecan (Carya illinoinensis) populations. The Journal of Heredity, v. 91, n. 1, p. 72-74, 2000.

SAMPSON, J.F.; HOPPER, S.D.; JAMES, S.H. Temporal variation in allele frequencies in the pollen pool of Eucalyptus rhodantha. Heredity, v. 65, p. 189-199, 1990.

SAMPSON, J.F.; HOPPER, S.D.; JAMES, S.H. The mating system and genetic diversity of the Australian Arid Zone Mallae, Eucalyptus rameliana. Australian Journal of Botany, v. 43, p. 461-474, 1995.

SAMPSON, J.F.; HOPPER, S.D.; JAMES, S.H. The mating system and population structure in a bird-pollinated mallee, Eucalyptus rhodantha. Heredity, v. 63 , p. 383393, 1989.

SATTERTWATTE, F.E. An approximate of estimates of variance components. Biometrics Bulletin, v. 2, p. 110-114, 1946.

SCHEMESKE, D.W.; LANDE, R. The evolution of seft-fertilization and inbreeding depression in plants. II Empirical observations. Evolution, v. 39, n. 1, p. 41-52, 1985.

SCHIMIDT-ADAM, G.; YOUNG, A.G.; MURRAY, B.G. Low outcrossing rates and shift pollinators in New Zealand Pohukawa (Metrosideros excelsa; Myrtaceae). Australian Journal of Botany, v. 87, p. 1265-1271, 2000.

SCHNABEL; A.; NASON, J.D.; HAMRICK, J.L. Understanding the populations genetic structure of Gleditsia triancanthos L.: Seed dispersal and variation in female reproductive success. Molecular Ecology, v. 7, p. 819-832, 1998.

SCHOEN, D.J.; CLEGG, M.T. Estimation of mating system parameters when outcrossing events are correlated. Proceedings National Academy Science, v. 81, p. 5258-5262, 1984.

SEAONE, E; KAGEYAMA, P.Y.; SEBBENN, A.M. Efeitos da fragmentação florestal sobre a estrutura genética de populações de Esenbeckia leiocarpa. Scientia Forestalis, 2000. 30 pag. (no prelo) 
SEBBENN, A.M. Estrutura genética de subpopulações de Genipa americana L. (RUBIACEAE) em mata ciliar a partir de isoenzimas. Piracicaba, 1997. 107 p. Tese (Mestrado) - Escola Superior de Agricultura "Luiz de Queiroz", Universiddade de São Paulo.

SEBBENN, A.M. KAGEYAMA, P.Y.; VENCOVSKY, R. Estrutura genética de subpopulações de Genipa americana L. (RUBIACEAE) em mata ciliar a partir de isoenzimas. Revista do Instituto Florestal, v. 10, n. 1, p. 95-108, 1998a.

SEBBENN, A.M.; DURIGAN, J.; SIQUEIRA, A.C.M.F.; PONTINHA, A.A.S. Teste de procedências de Grevilha robusta A. Cunn. Revista do Instituto Florestal, v. 11, n. 1 , p. $65-73,1999 \mathrm{a}$.

SEBBENN, A.M.; ETTORRI, L.C.; SATO, A. Teste de procedências de Pinus oocarpa Schiede em três regióes do Estado de São Paulo. Revista do Instituto Florestal, 19 pag., 2001. (submetido)

SEBBENN, A.M.; KAGEYAMA, P. Y. \& VENCOSVKY, R. Variabilidade genética, sistema reprodutivo e estrutura genética espacial em Genipa americana L. através de marcadores isoenzimáticos. Scientia Forestalis, v. 53, p. 15-30, 1998 b.

SEBBENN, A.M.; SEAONE, C.E; KAGEYAMA, P.Y. \& VENCOVSKY, R. Efeitos do manejo florestal sobre a estrutura genética de Caixeta - Tabebuia cassinoides, no Vale do Ribeira, SP. Scientia Forestalis, 32 pag., 2000a. (no prelo)

SEBBENN, A.M.; SIQUEIRA, A.C.M. F.; GURGEL GARRIDO, L. M. A. Interação progênies $\mathrm{x}$ locais e variabilidade genética em Jequitibá-Rosa - Cariniana legalis (Mart.) O. Ktze. Revista do Instituto Florestal, v. 12, n. 1, p. 13-23, 2000 c.

SEBBENN, A.M; SIQUEIRA, A.C.M.F. VENCOVSKY, R.; MACHADO, J.A.R. Interação genótipo ambiente na conservação ex situ de Peltophorum dubium, em duas regiões do Estado de São Paulo. Revista do Instituto Florestal, v. 11, n. 1, p. 75-89, $1999 b$.

SEBBENN, A.M.; SIQUEIRA, A.C.M.F.; KAGEYAMA, P.Y.; DI DIO J., O.P. Estrutura genética de Pterogine nitens Tul. (CAESALPINACEAE) através de caracteres quantitativos. Scientia Forestalis, v. 56, p. 29-40, 2000 b. 
SEBBENN, A.M.; SIQUEIRA, A.C.M.F.; KAGEYAMA, P.Y.; MACHADO, J.A.R. Parâmetros genéticos na conservação de cabreúva - Myroxylon peruiferum L. F. Allemão. Scientia Forestalis, Piracicaba, SP, v. 53, p. 31-38, 1998c.

SEOANE, C.E.S. Efeitos da fragmentação florestal sobre a estrutura genética de populações de Esenbeckia leiocarpa Engl. - Guarantã - Um exemplo de espécie arbórea tropical climáxica de distribuição agregada. Campinas, 1998, 80 p. Tese (Mestrado) - Universidade de Campinas.

SHAW, D.V.; ALLARD, R.W. Estimation of outcroassin rates in Douglas-Fir using isozymes markers. Theorical and Applied Genetics, v. 62, p. 113-120, 1982.

SHEA, R.G. Effects of population structure and cone production on outcrossing rates in Engelmann Spruce and Subalpine Fir. Evolution, v. 41, p. 124-136, 1987.

SHELBOURNE, C.J.A.; STONECYPHER, R.W. The inheritance of bole straightness in young Loblolly-Pine. Silvae Genetica, v. 20, p. 151-156, 1969.

SIEGISMUND, H.R.; KJAER, E.D. Outcrossing rates in two stands of Noble Fir (Abies procera Rehd.) in Denmark. Silvae Genetica, v. 46, n. 2-3, p. 144-146, 1997.

SILVA, J.C.; BORRALHO, N.M.G.; WELLENDORF, H. Genetic paramenters estimates for diameter grown, pilodyn penetration and spiral grain in Picea abies (L.) KARST. Silvae Genetica, v. 49, p. 29-36, 2000.

SIQUEIRA, A.C.M.F; FIGLIOLIA, M.B. Conservação genética, produção e intercâmbio de sementes de espécies tropicais. In: "ESPÉCIES NÃO TRADICIONAIS PARA PLANTIOS COM FINALIDADES PRODUTIVAS E AMBIENTAIS". Curitiba, PR, 1998. EMBRAPA, 1998. p. 7-22.

SIQUEIRA, A.C.M.F.; NOGUEIRA, J.C.B.; KAGEYAMA, P.Y. Conservação de recursos genéticos ex situ de cumbaru (Dipteryx alata Vog.) - Leguminosae. Revista do Instituto Florestal, v. 5, n. 2, p.: 231-43, 1993.

SIQUEIRA, A.C.M.F.; NOGUEIRA, J.C.B.; ZANATTO, A.C.; MARIANO; G.; CRUZ, I.I. O jequitibá-rosa - Cariniana legalis (Mart.) O. Ktze. Uma espécie em extinção. Boletin Técnico do IF, v. 40A, p. 291-301, 1986. 
SIQUEIRA, A.C.M.F.; NOGUEIRA, J.C.B.; ZANATTO, A.C.S. O cumbaru Dipteryx alata Vog. Estudo de diferentes procedências e progênies. Boletim Técnico IF, v. 40A, p. 281-290, 1986.

SIQUEIRA, A.C.M.F.; SEBBENN, A.M.; KAGEYAMA, P.Y.; ETTORI, L.C. Distribuição da variação genética entre e dentro de populações de Balfourodendron riedelianum (Engler) Engler para a conservação ex situ. Revista do Instituto Florestal, 2000. (no prelo)

SNIEZKO, R.A.; ZOBEL, B.J. Seedling height and diameter variation of various degrees of inbred and outcrossi pregenies of Loblolly Pine. Silvae Genetica. v. 37, p. 50-60, 1988.

SNYDER, T.P.; STEWART, D.A.; STRICKLER, A.F. Temporal analysis of breeding structure in jack pine (Pinus banksiana Lamb.). Canadian Journal Forest Research, v. 15, p. 1159-1166, 1985.

SOKAL, R.R.; ROHLF, F.J. Biometry: the principles and pratice of statistics in biological research. London: Copyright Ltd, $1981.859 \mathrm{p}$.

SOLTIS, D.E.; HAUFLER, C.H.; DARROW, D.C.; GASTONY, G.J. Starch gel electrophoresis of ferns: A copilation of griding buffers, gel and electrode buffers, and staining schedules. Americam Fern Journal, v. 73, n. 1, p. 9-26, 1983.

SORENSEN, F.C. Effects os sib mating and wind pollination on nursery seedling size, growth components, and phenology of Douglas-Fir seed-orchard progenies. Canadian Journal of Forest Research, v. 27, p. 557-566, 1997.

SORENSEN, F.C. Frequence of seedlings from natural self-fertillization in costal Douglas-Fir. Silvae Genetica, v. 22, p. 20-24, 1973.

SORENSEN, F.C.; MILES, R. Inbreeding depression in hight, height growth. and survival of Douglas-Fr, Ponderosa Pine, and Noble Fir to 10 years of age. Forest Science, v. 28 , n. 2, p. 283-292, 1982.

SORENSEN, F.C.; MILES, R. Self-pollinization effects on Douglas-Fir and Ponderosa pine seeds and seedlings. Silvae Genetica, v. 23, n. 5, p. 135-138, 1974. 
SORENSEN, F.C.; WHTE, T.L. Effect of natural inbreeding on variance structure in tests of wind-pollination Douglas-Fir progenies. Forest Science, v. 34, n. 1, p. 102$118,1988$.

SOUZA Jr., C.L. Componentes da variância genética no melhoramento vegetal. Piracicaba: Piracicaba: FEALQ, 1989. 134 p.

SOUZA, L.M.F.I. Estrutura genética de populações naturais de Chorisia speciosa St. Hil. (Bombacaceae) em fragmentos florestais na região de Bauru (SP) - Brasil. Piracicaba, 1997, 76 p. Tese (Mestrado) - Escola Superior de Agricultura "Luiz de Queiroz", Universidade de São Paulo.

SQUILLACE, A.E. Average genetic correlations among offspring from open-pollinated forest trees. Silvae Genetica, v. 23, p. 149-156, 1974.

SQUILLACE, A.E.; GODDARD, R.E. Selfing in clonal seed orchards of Slash Pine. Forest Science, v. 28, n. 1, p. 71-78, 1982.

STEBBINS, G.L. Introduction. In: SOLTIS, D.E.; SOLTIS, P.S. (Ed.). Isozymes in plant biology. Portland: Dioscorides Press, 1989. p.73-86.

STUBER, C.W. Estimation of genetic variances using inbred relatives. Crop Science, v. 10, p. 129-135, 1970.

SURLES, S.E.; ARNOLD, J.; SCHNABEL, A.; HAMRICK, J.L.; BONGARTEN, B.C. Genetic relatedness in open-pollinated families of two leguminous tree species, Robinia pseudoacacia L. and Gleditsia triacanthos L. Theorical and Applied Genetics, v. 80, p. 49-56, 1990.

SURLES, S.E.; HAMRICK, J.L.; BONGARTEN, B.C. Mating systems in openpollinated families of Black Locust (Robinia pseudoacacia). Silvae Genetica, v. 39, n. 1, p. 35-40, 1989.

SWOFFORD, D.L.; SELANDER, R.B. BIOSYS-1. A FORTRAN computer program for the analysis of allelic variation in population genetics and biochemical systematics. Journal of Heredity, v. 72, p. 282-283, 1989.

TELLES, M.P.C. Diversidade genética e estrutura populacional de Cagaiteira (Eugenia dysenterica DC.) do sudoeste de Goias. Goiania, 2000, 129 p. Tese (Mestrado) - Universidade Federal de Goias. 
VENCOVSKY, R. Biometrical approaches for molecular markes estimation of effective population size. In: PROCEEDINGS OF THE INTERNATIONAL WORKSHOP ON AGRICULTURAL BIOTECHNOLOGY. Piracicaba: ESALQ/USP, 1997. p. 233-234.

VENCOVSKY, R. Tamanho efetivo populacional na coleta $\mathrm{e}$ preservação de germoplasmas de espécies alógamas. IPEF, v. 35, p. 79-84, 1987.

VENCOVSKY, $R$. Variance of an estimate of outcrossing rate. Revista Brasileira de Genética, v. 17, n. 3, p. 349-51, 1994.

VICTOR, M. A devastação florestal. Sociedade Brasileira de Silvicultura, p. 28-32, 1975.

VITTI, A.P.; KAGEYAMA, P.Y.; COSTA, L.G.S.; BLLA, A.D.; SEGUESE, F.; SLLVA, F.F. Estrutura genética em populações de Cecropia cinerea \& Esenbekia leiocarpa plantadas segundo a sucessão secundária. In: ANAIS DO $2^{0}$ CONGRESSO NACIONAL SOBRE ESSÊNCIAS NATIVAS: CONSERVAÇÃO E BIODIVERSIDADE. Revista do Instituto Florestal de São Paulo, y. 4: p. 983-1272, 1992.

WANG, C.H.T.; LIN, T.P. Inheritance and linkage ralationsship os allozymes, and estimation of outcrossin rates in a seed orchard of Cunninghamia konishii Hay. Silvae Genetica, v. 47, p. 33-37, 1998.

WEIR, B.S. Genetic data analysis II. Methods for discrete population genetic data. Suderland: Sinauer, 1996. 445 p.

WEIR, B.S.; COCKERHAM, C.C. Two-locus theory in quantitative genetics. In: POLLAK, E; KEMPTHORNE, O; BAILEY, Jr., T.B. (Ed.). Proceedings of the INTERnational Conference on Quantitative Genetics. Ames: Iowa State University Press, 1977. p. 247-269,

WILCOX, M.D. Inbreeding depression ans genetic variances estimated from self and cross-pollinated famuilies of Pinus radiata. Silvae Genetica, v.32, p. 89-96, 1983.

WILLIANS, C.G.; SAVOLAINEN, O. A unifying framework for inbreeding depression in coniferas. Forest Science, v. 41, p. 124-131, 1993.

WORKMAN, P.; NISWANDER, J.L. Population studies on southwestern Indian Tribes.

II. Local genetic differentiation in the Papago. American Journal Human Genetic, v. 22, p. 24-49, 1970. 
WRIGHT, J.W. A simplified design for combined prevenance and progeny testing. Silvae Genetica, v. 27, n. 2, p. 68-70, 1978.

WRIGHT, S. Evolution and genetics of populations. V2. The theory of genes frequencies. Chicago: University of Chicago Press, 1969. 511 p.

WRIGHT, S. Evolution and he genetics populations. Annual Eugenic, v.15, p. 323-354, 1951.

WRIGHT, S. Evolution and the genetics of populations. Vol. 4. Variability within and amosng natural populations. Chicago: University of Chicago Press, 1978, 423 p.

WRIGHT, S. Isolation by distance. Genetics, v. 28, n. 2, p. 114-138, 1943.

WRIGHT, S. Systems of mating. Genetics, v. 6, p. 111-178, 1921.

WRIGHT, S. The interpretation of population structure by $F$-statistics with special regard to systems of mating. Evolution, v. 19, p. 395-420, 1965.

WU, H. X.; MATHESON, A.C.; SPENCER, D. Inbreeding in Pinus radiata. 1. The effect of inbreeding on growth, survival and variance. Theorical and Applied Genetics, v. 97, p. 1256-1268, 1998.

XIE, C.Y. \& KNOWLES, P. Mating system and effective pollen immigration in a Norway Spruce [Pecea abies (L.) Karst] plantation. Silvae Genetica, y. 43, n. 1, p. 48-52, 1994.

YANG, R.C.; YEH, F.C.; YANCHUK, A.D. F-Statistics for quantitative traits: Estimation and inference. Forest Genetics, v. 23, p. 23-31, 1995.

YEH, F.C.; BRUNE, A.; CHELIAK, W.N.; CHIPMAN, D.C. Mating system of Eucalyptus citriodora in a seed-production area. Canadian Journal of Forest Research, v. 13, n. 6, p. 1051-1055, 1983.

YEH, F.C.; HEAMAN, J.C. Estimating genetic parameters of height growth in sevenyears old coastal Douglas-Fir from disconnected dialles. Forest Science, v. 33, p. 4, p. 946-957, 1987.

ZHENG, Y.Q.; ENNOS, R; WANG, H.R. Provenance variation and genetic parameters in a trial of Pinus caribaea var. honduresnsis Barr. and Golf. Forest Genetics, v. 1, n. 3, p. $165-174,1994$.

ZOBEL, B.; TALBERT, J. Applied forest tree improvement. Raleigh: North Carolina State University, 1984. $496 \mathrm{p}$. 